
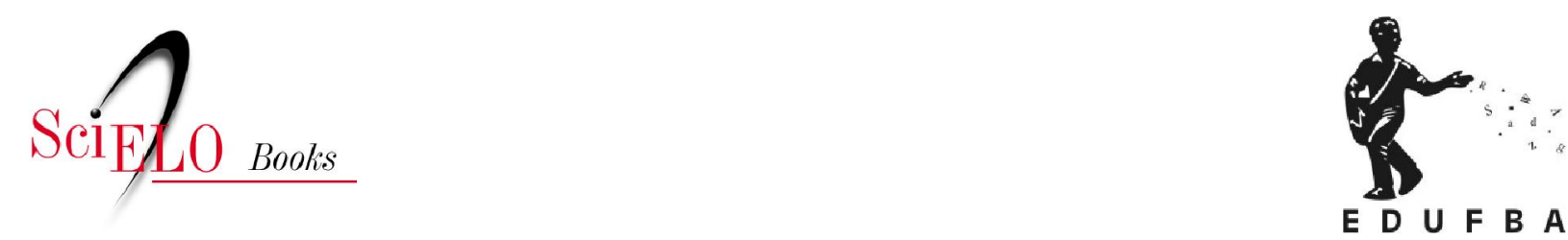

\title{
A Petrobras e a gestão do território no Recôncavo Baiano
}

\author{
Cristóvão Brito
}

BRITO, C. A PETROBRAS e a gestão do território no Recôncavo Baiano [online]. Salvador: EDUFBA, 2008. 236 p. ISBN 978-85-232-0921-6. Available from SciELO Books $<\underline{\text { http://books.scielo.org }>\text {. }}$

\section{@(1) $(0)$}

All the contents of this work, except where otherwise noted, is licensed under a Creative Commons Attribution-Non Commercial-ShareAlike 3.0 Unported.

Todo o conteúdo deste trabalho, exceto quando houver ressalva, é publicado sob a licença Creative Commons Atribuição Uso Não Comercial - Partilha nos Mesmos Termos 3.0 Não adaptada.

Todo el contenido de esta obra, excepto donde se indique lo contrario, está bajo licencia de la licencia Creative Commons Reconocimento-NoComercial-CompartirIgual 3.0 Unported. 


\section{A PETROBRASE A \\ GESTÃO DO TERRITÓRIO NO RECÔNCAVO BAIANO}




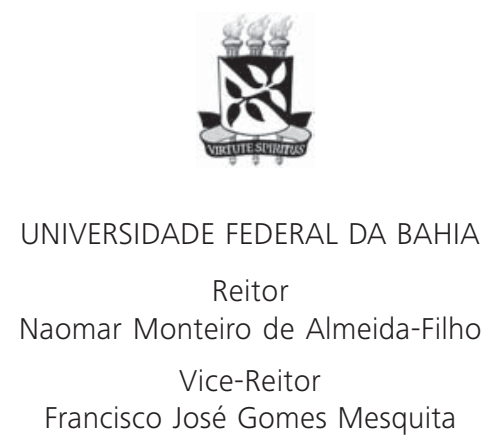

EDITORA DA UNIVERSIDADE FEDERAL DA BAHIA

Diretora

Flávia Goullart Mota Garcia Rosa

Conselho Editorial

Titulares

Ângelo Szaniecki Perret Serpa

Caiuby Alves da Costa

Charbel Ninõ El-Hani

Dante Eustachio Lucchesi Ramacciotti

José Teixeira Cavalcante Filho

Maria do Carmo Soares Freitas

Suplentes

Alberto Brum Novaes

Antônio Fernando Guerreiro de Freitas

Armindo Jorge de Carvalho Bião

Evelina de Carvalho Sá Hoisel

Cleise Furtado Mendes

Maria Vidal de Negreiros Camargo 
CRISTÓVÃO BRITO

\title{
A PETROBRASE A \\ GESTÃO DO TERRITÓRIO NO RECÔNCAVO BAIANO
}

\author{
EDUFBA
}

Salvador, 2008 
(C)2008, By

Direitos de edição cedidos à EDUFBA

Feito o depósito legal.

Revisão e normalização

Susane Barros

Editoração Eletrônica e Capa

Rodrigo Oyarzábal Schlabitz

O autor permite a reprodução de qualquer parte

desta obra, desde que citada a fonte.

Biblioteca Central Reitor Macêdo Costa - UFBA

Brito, Cristóvão de Cássio da Trindade.

A PETROBRAS e a gestão do território no Recôncavo Baiano / Cristóvão Brito. - Salvador : EDUFBA, 2008.

236 p. : il.

Inclui anexo.

Originalmente apresentada como tese (doutorado) - Universidade Federal de Santa

Catarina, 2004.

ISBN : 978-85-232-0542-3

1. Geografia humana - Bahia. 2. Territorialidade humana - Recôncavo (BA)

3 PETROBRAS - Recôncavo (BA). 4. Ciência política - Recôncavo (BA). I. Título.

CDD -918.142

CDU - 911.3(813.8)

\section{fapesb 会}

Fundaça de Amparo

a Pesquisa do Estado da Bahia

EDUFBA

Rua Barão de Jeremoabo, s/n - Campus de Ondina,

40170-290 Salvador-BA

Tel/fax: (71) 3283-6164

www.edufba.ufba.br

edufba@ufba.br 


\section{Sumário}

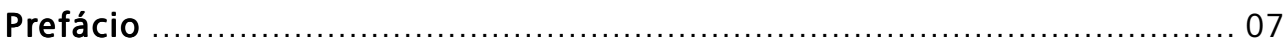

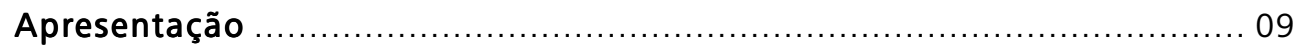

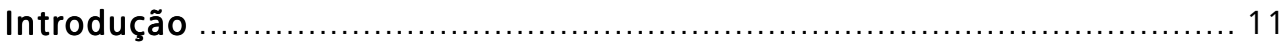

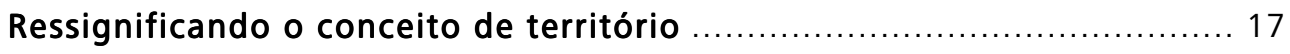

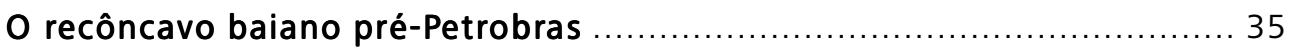

As relações sociais e de produção entre os agentes e suas implicações espaciais no Recôncavo Fumageiro

A inserção da Petrobras no Recôncavo Baiano

A Petrobras e o processo de reorganização territorial no Recôncavo Baiano 163

Considerações Finais

Referências

Anexo 


\section{Agradecimentos}

Registro aqui a minha gratidão aos caríssimos professores: Dra. Leila Christina Dias (UFSC) e Dr. Sylvio Bandeira de Mello e Silva (UCSALUJFA) pelo incentivo e pela leitura dos originais e as respectivas sugestões. Agradeço também à Fundação de Amparo à Pesquisa do Estado da Bahia (Fapesb) pelo apoio financeiro para a realização do projeto de publicação deste livro, e a todos quantos puderam contribuir direta ou indiretamente. Não poderia esquecer você, prezado leitor, para quem foi pensado submeter às suas críticas, os conteúdos deste livro.

Para Adilma e Nara, esposa e filha. 


\section{Prefácio}

Chama-se Recôncavo a região que circunda a Bahia de Todos os Santos, formando o grande anfiteatro no qual, há mais de quatrocentos anos, se vem desenrolando um dos mais antigos capítulos da colonização do Brasil, que ali teve o seu começo e que exatamente ali tem, hoje, uma das perspectivas mais promissoras do seu futuro.

COSTA PINTO

Cristóvão Brito traz com este livro sobre a Petrobras e a Gestão do Território no Recôncavo Baiano uma relevante contribuição para a Geografia da Bahia em várias direções. Entretanto, antes de discorrer sobre elas, quero ressaltar, na figura do autor, a importância de uma formação universitária sólida, buscada com tenacidade e expressando uma escolha consciente. Cristóvão é Bacharel e Mestre em Geografia pela Universidade Federal da Bahia. Sua dissertação de mestrado, que tive a satisfação de orientar, agrega conhecimentos inovadores sobre a recente expansão urbana de Salvador, tendo como título A produção da escassez de terrenos em Salvador-BA e suas conseqüências para sua expansão futura. Na banca, recebeu elogios de examinadores exigentes como Fernando Cardoso Pedrão e Pedro de Almeida Vasconcelos que destacaram a abordagem original e a relevância acadêmica.

Em 1996, torna-se professor universitário, mediante concurso público, da Universidade do Estado da Bahia (Uneb), em Salvador. Alguns anos depois, parte com sua família para o Doutorado na Universidade Federal de Santa Catarina, em Florianópolis, sob a competente orientação da colega Leila Christina Dias. Recentemente, ingressou na Universidade Federal da Bahia, também mediante concurso, como Professor Adjunto do Departamento de Geografia/Instituto de Geociências.

Este livro é, a rigor, o resultado de sua tese de doutorado defendida com brilhantismo em 2004. Sobre a contribuição do autor, há, como já foi mencionado, vários pontos a destacar. Logo de início, percebe-se uma sólida fundamentação teórica e conceitual que vai direcionar a metodologia, a análise e a interpretação das grandes questões do tema escolhido. Cristóvão soube selecionar e utilizar bem a contribuição de diferentes autores, dentre os quais destaco a cientista política Hannah Arendt, em boa hora trazida para a análise da arena política dos territórios em nosso meio. Cristóvão integrou com originalidade muitas abordagens ao formular as questões centrais de sua pesquisa em torno da dinâmica temporal e territorial do Recôncavo baiano com o advento de uma grande corporação, a Petrobras. A rigor, portanto, é uma contribuição para a Geografia 
Política, na escala de um território regional, com a perspectiva da construção de um território corporativo ou de uma região-empresa.

Assim, a detalhada análise da evolução e dinâmica da territorialidade corporativa, em sua inserção em um tradicional contexto regional, é o segundo ponto a ressaltar. Com efeito, a introdução e a expansão da Petrobras no Recôncavo da Bahia foram trabalhadas de forma pertinente, profundamente enraizada nas questões territoriais e em seus desdobramentos.

Mas há um terceiro e último ponto, para não me alongar demais, a destacar na obra de Cristóvão: é o estudo geográfico do Recôncavo pré- Petrobras. Isto se deve ao fato de que faltava na bibliografia geográfica um tratamento aprofundado da questão do Recôncavo dos usineiros e do Recôncavo fumageiro e Cristóvão o faz muito bem sob o ângulo de uma Geografia Regional Histórica, fundamental para a compreensão do presente. O tema Recôncavo, aliás, ficou um tanto marginalizado na Bahia com o surgimento, a partir da década de 70 do século passado, das questões metropolitanas e da própria cidade do Salvador, em fase de grande expansão. Mas, ele tende a voltar agora, em boa hora, com o crescimento da compreensão da importância estratégica da complexa integração macrorregional em torno da capital baiana e com a dinâmica dos movimentos reivindicatórios, liderados por municípios organizados em associações, que acabaram resultando, por exemplo, na criação da Universidade Federal do Recôncavo da Bahia, com sede em Cruz das Almas e atividades acadêmicas em várias cidades da região.

Espero que novos trabalhos de Cristóvão e de outros autores avancem na discussão sobre a dinâmica dos territórios corporativos, por exemplo, de forma comparativa entre o norte fluminense e o Recôncavo da Bahia, ambos sob o impacto da Petrobras, e sobre a atual Geografia do açúcar e do fumo na Bahia.

São temas candentes que são motivados pela leitura de uma contribuição já tão importante como a de Cristóvão para a Geografia da Bahia.

Finalmente, assinalo que estudos desta natureza contribuem para imaginar "perspectivas mais promissoras", segundo Costa Pinto, para o futuro do Recôncavo que só podem ocorrer se forem priorizados os processos de construção de um projeto regional e de uma nova gestão social do território, tudo isto trabalhado de forma ampla, participativa e integrada, envolvendo o Estado, em suas diferentes escalas, as Empresas e a Sociedade Civil, com base em critérios de eficiência e equidade sócio-territorial.

Sylvio Bandeira de Mello e Silva Universidade Católica do Salvador e 


\section{Apresentação}

Nos anos recentes, o território vem constituindo-se numa agenda de pesquisa que reúne significados e abordagens disciplinares diversas. Em alguns escritos a palavra parece substituir a região ou o espaço, porque é utilizada como referência apenas à localização e à extensão dos fenômenos, sem maior compromisso com a teorização. Em outros, identificamos a polissemia e a amplitude do conceito, e também a forma como geógrafos, antropólogos, sociólogos, economistas e cientistas políticos trazem para seus campos de conhecimento a reflexão sobre a dimensão do poder, do controle e da apropriação. Emerge assim o que Milton Santos nomeou de uma família de conceitos: território, territorialidade, territorialização, poder, controle, apropriação e violência não estão insulados, mas articulados entre si, como um conjunto de lentes teórico-metodológicas que construímos a partir das experiências que temos do mundo. São essas precisamente as lentes que Cristóvão Brito escolheu para compreender as transformações na configuração territorial do Recôncavo Baiano, entre os anos 1930 e o início do século XXI.

Largamente inspirado nas idéias de Hannah Arendt, teórica alemã que assistiu e estudou a formação dos regimes totalitários instalados na Europa no século XX, Cristóvão Brito chama a atenção para um tema central da vasta obra de Arendt: a distinção entre poder e violência. Ao pensar o poder como uma "ação em concerto", que emerge da relação entre indivíduos livres e iguais, a autora se opõe à tradição do pensamento político que entende o poder como relação de mando e obediência. A tradição que Arendt defende é outra: a que fundamenta o conceito de poder numa relação de consentimento, em que as instituições se sustentam pelo "apoio do povo". A tese arendtiana de que poder e violência são opostos; onde um domina absolutamente, o outro está ausente é atualizada por Cristóvão Brito, para pensar a territorialidade humana como o conjunto de estratégias de grupos sociais para ocupar, usar, controlar, apropriar e se identificar com uma parcela específica do espaço geográfico da Bahia, convertendo-a em seu território.

O autor analisa o universo político, social, econômico, técnico-produtivo, e espacial do Recôncavo Baiano em dois períodos principais - 1930 a meados dos anos 1950 e a partir daí até o ano 2000 -, seguindo os principais sujeitos que atuam em diferentes escalas espaciais: usineiros de açúcar, fornecedores de cana, trabalhadores de canaviais e usinas, lavradores de fumo e operários das fábricas de fumo, fazendeiros, negociantes e industriais do fumo, Governos federal, estadual e municipal, banqueiros e grandes negociantes, Conselho Nacional de Petróleo (e a seguir a Petrobras). A investigação decompõe as relações e os elementos constitutivos desta fração espacial do estado da Bahia e esclarece os tipos de pressão exercidos pelos usineiros de açúcar sobre os fornecedores de cana e os pequenos usineiros, e a articulação entre os maiores usineiros, o capital bancário e os Governos estadual e federal, engendrando o processo de concentração da propriedade da terra. O estado de pobreza extrema da maioria da população de canavieiros, o agravamento das tensões sociais 
provocadas por relações sociais de trabalho quase escravas, na qual predominam relações de mando e de obediência, e o emprego de ações violentas caracterizam o que Cristovão Brito chamou de dissolução do território organizado, principalmente, em torno das demandas dos usineiros de açúcar.

Da leitura deste livro emerge a complexa teia de ações empreendidas pela Petrobras nos anos seguintes para a gestão do território de uma parte do Recôncavo Baiano, aquela mais diretamente associada às suas ações. A redação fluente revela um raciocínio claro: compreendemos o conjunto de interesses e de disputas que, na escala federal, desde os anos 1930, move a construção de um projeto nacional de autonomia do desenvolvimento nacional, com destaque para a implantação da indústria do aço e para o monopólio estatal do petróleo; vemos como progressivamente a Petrobras incorpora demandas dos atores regionais, através da articulação entre os seus projetos, que a transformaria anos mais tarde numa grande corporação de petróleo, e os investimentos governamentais com apoio da SUDENE: se até o início da década de 1950 o meio de transporte de carga mais utilizado no Recôncavo era o carro-de-boi, transitando por solos de massapé lamacentos durante o período das chuvas, as operações de transporte da Petrobras passam a demandar a abertura de estradas - rodovias asfaltadas são inauguradas ligando a cidade de Salvador às áreas produtoras de petróleo. A grande massa monetária em circulação na forma de salários diretos e indiretos, os gastos diversos da Petrobras e o pagamento de impostos e taxas aos municípios da região de produção de petróleo se concretizam em urbanização. Quando Milton Santos escreveu, em 1959, que o Recôncavo é, por excelência, a região de cidades da Bahia, os municípios da área petrolífera atraíam cada vez mais população, registrando, nos censos demográficos de 1960 e 1970, as mais altas taxas de crescimento urbano.

Cristóvão Brito revela rigor metodológico na condução da investigação: pesquisou arquivos de jornais baianos da época, entrevistou ex-proprietários de usinas de açúcar, sindicalistas e trabalhadores do petróleo, ouviu com atenção pessoas idosas e suas histórias de vida e coletou informações em diferentes municípios do Recôncavo Baiano. Levantamentos de dados primários e secundários resultaram numa cartografia original que representa o conjunto de interações espaciais sob o comando das principais cidades do Recôncavo.

Além do domínio teórico-metodológico, Cristóvão Brito revela imaginação geográfica: forma imagens de objetos geográficos que não haviam sido percebidos, atribuindo-lhes sentido através da ação de uma miríade de atores. Problematizando a presença da Petrobras no Recôncavo Baiano, o estudo de Cristóvão leva à reflexão mais ampla sobre as relações entre corporação e território. Ao mesmo tempo convida estudantes, pesquisadores e planejadores ao diálogo em novo contexto, no qual a teoria social contemporânea incorpora a sua agenda, teórica e política, a dimensão espacial da sociedade.

Leila Christina Dias

Universidade Federal de Santa Catarina 


\section{Introdução}

Busca-se neste livro realizar um esforço de ressignificar o conceito de territorialidade como um fenômeno sócio-político e espacial e de sua expressão geográfica, o território, à luz das relações entre dados agentes sociais mediadas pelo poder em uma dada extensão espacial (ambos, conteúdo e continente, doravante serão mencionados simplesmente território).

Com base em Arendt (1994), parte-se do princípio de que o poder não pertence a um agente, mas a todos quantos se achem envolvidos numa relação social, e que, o mesmo encerra ações tomadas em concerto em que pese todas as assimetrias envolvidas nas relações sociais, mas nunca sob coação e/ou resultantes de relação vertical.

É nessa perspectiva que se elegeu o Recôncavo Baiano como arena apropriada à análise dos processos sociais e de suas respectivas formas-conteúdo, resultantes das ações empreendidas pelos usineiros de açúcar, Conselho Nacional de Petróleo (CNP), Petrobras, fazendeiros, trabalhadores do petróleo, trabalhadores canavieiros e o Estado/Governo (inclusive seus órgãos descentralizados) nas escalas federal, estadual e municipal, no período entre 1940 e 2000.

No Recôncavo Baiano, cuja organização espacial era orientada principalmente pelas demandas dos usineiros de açúcar, desde o início do século XX, por volta dos anos 1940/1950 as relações sociais e de produção se davam de tal maneira sob o mando dos usineiros, que o fenômeno do poder se encontrava substancialmente enfraquecido, e os mecanismos de coação e dominação eram os que mais se destacavam.

É de se notar que durante esse período, em meio a uma economia regional de base agromercantil em franco processo de declínio, até mesmo os usineiros perdiam força, enquanto o CNP e, depois, a Petrobras, adquiriam significativa visibilidade, com a ampliação das descobertas de novos e grandes campos de petróleo e de gás natural na área da Bacia Sedimentar do Recôncavo.

A Petrobras foi criada em 1953 pelo Governo federal e entrou em operação em 1954. Antes da criação dessa empresa, o Governo federal já explorava petróleo desde 1941 no Recôncavo Baiano, por meio do CNP. O Recôncavo Baiano que, até a década de 1960, constituía a única província petrolífera nacional, não era uma região desabitada. Quando o CNP se instalou, já encontrou uma atividade econômica organizada, a qual desfrutava de enorme força política e econômica, regionalmente, e, também, na escala nacional - a grande lavoura canavieira e a industrialização do açúcar por meio de grandes usinas e o cultivo do fumo e sua manufatura. 
Os albores da década de 1960 inauguraram uma nova era no Recôncavo Baiano. A Petrobras, pressionada interna e externamente por seus interlocutores regionais - industriais, banqueiros, usineiros de açúcar, fazendeiros, trabalhadores do petróleo, trabalhadores canavieiros e o Governo estadual - decidiu agir de maneira pactuada com esses agentes, implicando uma nova territorialidade e o surgimento de um novo território no Recôncavo Baiano remodelado em grande parte.

Esse novo território não tem a extensão de todo o Recôncavo Baiano. Ele coincide com a área contínua de ação da corporação estatal de petróleo nas atividades de pesquisa, extração e industrialização do óleo e do gás natural, nos municípios limitados desde o mar da Baía de Todos os Santos e a costa atlântica, até o município de Esplanada localizado ao Norte de Salvador (já fora do Recôncavo Baiano) e a Oeste pelos municípios de São Sebastião do Passé e Alagoinhas.

Nesse novo território são notáveis as diferenças que se materializam nas relações de trabalho, as quais se desenvolvem em bases eminentemente contratuais e impessoais à medida que se avança no tempo; na urbanização, com o surgimento de novas cidades resultantes de emancipações municipais, e na ampliação dos efetivos urbanos; no aumento da complexidade do fenômeno urbano e da funcionalidade dos núcleos urbanos; e no sistema de interações espaciais entre cada cidade e sua maior abertura para sistemas urbano-regionais situados alhures, tendo por base a instalação e/ou o melhoramento de infraestrutura física - estradas, telecomunicações, energia elétrica etc. (PRED, 1979). Por fim, os investimentos econômicos da Petrobras tornaram possível a instalação da indústria moderna na Bahia, carreada pela siderurgia de metais ferrosos e não-ferrosos, pelas indústrias metalmecânicas, químicas, de refino de petróleo e petroquímica. Esse sistema industrial novo localiza-se, em grande medida, de maneira concentrada na Região Metropolitana de Salvador (RMS) criada formalmente no início dos anos 1970.

O interesse em explicar o processo de reorganização territorial no Recôncavo Baiano, entre 1940 e 2000 advém, primeiro, do conhecimento adquirido sobre sua geografia e história, por meio do qual se vislumbra a possibilidade concreta de operacionalização do conceito de território, como o defendido neste livro; e depois pela constatação de uma lacuna na explicação das transformações processadas ao longo do período em alusão, como sugere Brandão (1997).

Os estudos que buscam abordar sistematicamente o Recôncavo Baiano pósescravista em seus elementos mais significativos remontam basicamente ao fim dos anos 1950, com os trabalhos de Santos, M. (1959a), Azevedo, T. (1959a), Costa Pinto (1958) e o levantamento realizado pelo Conselho de Desenvolvimento do Recôncavo (BAHIA, 1972?), nos anos 1960, sobre as condições econômicas, sociais e da exploração da terra. Os referidos estudos flagraram o início de 
todo o processo de mudanças no Recôncavo Baiano. Ao longo do tempo, outros pesquisadores realizaram estudos sobre o Recôncavo Baiano, mas de cunho eminentemente temáticos a exemplo de Silva, M. (1972), Silva, J. (1973), Asevedo (1975), Souza, G. (1976; 1980), Santos, V. (1990) e Cunha (1995). Dessa maneira, os processos sociais que revolveram o velho Recôncavo Baiano ao longo de seis décadas, transformando substancialmente os elementos definidores de sua estrutura econômica, técnico-produtiva, social, política e urbana, reclamam, hoje, explicações, pelo menos provisórias para a atual organização sócioespacial do presente no Recôncavo Baiano.

Para fazer revelar-se a natureza essencial das ações praticadas pelos agentes sociais no processo de dissolução de um território, e de construção e gestão de um outro no Recôncavo Baiano, partiu-se das seguintes questões: o que determinou a extinção do território organizado em torno das atividades canavieira e açucareira entre as décadas de 1940 e 1950? Em que condições e de que maneira, a Petrobras, junto com seus interlocutores regionais, conseguiu construir um território no Recôncavo Baiano, a partir dos anos 1960? Quais os mecanismos que a corporação utilizou para prover a gestão do território, e como foram implementados para resultar na configuração atual?

A formulação dessas questões fundamenta-se na crença de que o poder é substantivo para o conceito de território e que tal categoria recusa qualquer equivalência com dominação, controle, coação, violência ou outro termo correlato que possa significar objeção a mudanças no status quo. Para Arendt (1994), no mundo real não existe poder puro e nem violência pura, mas onde um prevalece, o outro se esvanece. É com base nessa perspectiva que se propõe tratar o território, a partir da formulação da seguinte idéia: onde as relações de poder forem fracas, esse território encontra-se em vias de dissolução; ao contrário, no território onde as relações de poder forem preponderantes, o mesmo estará cada vez mais afirmado.

Os procedimentos de análise incluíram uma periodização (POMIAN, 1993; SANTOS, M., 1985), motivada pela intenção de compreender os processos imanentes a cada um dos períodos em que as ações sociais de fundo eram reproduzidas. Por meio dessas ações sociais pôde-se evidenciar as possibilidades de emergência e de reprodução de um território organizado pela Petrobras no Recôncavo Baiano.

Fixando o início da análise nos anos 1940, e estendendo-a até 2000, verificase que, ao longo do tempo, a estrutura social e econômica associada às atividades de base essencialmente agroindustriais e mercantis foi atravessada por eventos (POMIAN, 1993; SANTOS, M., 1985), cujos resultados implicaram transformações nas formas e nas funções, gerando descontinuidades ou períodos de desenvolvimento de novos processos em ação no Recôncavo Baiano. 
Para os propósitos da pesquisa, foram identificados dois períodos essenciais: o primeiro envolve os processos em curso desde antes de 1940 até 1960, precisamente 1959, quando se deu a realização da Conferência do Petróleo organizada pelo Jornal $A$ Tarde em Salvador. Durante esse período é flagrante a estagnação em todos os meandros da vida social, econômica e produtiva do Recôncavo Baiano, implicando a existência de limites cada vez mais estreitos à reprodução ampliada dos capitais regionais, e o aguçamento das tensões sociais provocadas, principalmente, por relações sociais de trabalho quase escravistas, refletindo-se no processo de crise e posterior dissolução do território estruturado em torno do mando dos usineiros de açúcar e em parte sob o dos fazendeiros, proprietários de armazéns e de fabricantes de charutos. 0 segundo período inicia-se a partir de 1960, e desenvolve-se até a presente data, embalado pelos processos derivados das transformações emanadas pelas ações diretas e indiretas da Petrobras no Recôncavo Baiano, que resultaram na estruturação e desenvolvimento de um novo território a jusante e a montante das demandas da empresa.

Assim, as idéias centrais que permearam os dois períodos identificados vinculam-se aos processos de surgimento e de desaparecimento de um território e de surgimento e desenvolvimento de um outro entre tantos outros que possam existir ou ter existido.

A busca por respostas às questões principais da pesquisa implicou a necessidade de formulação de outras perguntas auxiliares à explanação de cada capítulo.

O esforço em fazer ressaltar as dimensões sócioespaciais subjacentes à proposta de abordagem do território nesse estudo, demandou uma pesquisa sistemática em arquivos de jornais da época - $A$ Tarde e $O$ Momento -, onde se procurou, nas edições diárias, identificar e analisar as matérias e reportagens mais importantes sobre o objeto de análise; leituras orientadas por temas em livros, artigos de periódicos, dissertações de mestrado, teses de doutorado, textos avulsos e documentos coligidos diretamente com as famílias dos autores e/ou em bibliotecas; auscultar pessoas idosas com história de vida ligada a assuntos pertinentes ao objeto de pesquisa, o que forneceu pistas valiosas ao entendimento de algumas questões; a aplicação de entrevistas abertas com ex-proprietários de usinas de açúcar, com o sindicato dos usineiros, trabalhadores canavieiros e o sindicato dos trabalhadores do petróleo, no sentido de fazer revelar os elementos fundadores de suas ações; e, por fim, visitas a localidades no Recôncavo Baiano onde se desenvolveram ações dos distintos agentes sociais.

As entrevistas, não estruturadas (LODI, 1974), foram realizadas entre os meses de maio e setembro de 2002, por meio dos quais se buscou extrair informações sobre as mais importantes formas de ação dos distintos agentes sociais envolvidos no processo de reprodução do território no Recôncavo Baiano ao lon- 
go dos períodos em análise. Seguindo a trajetória dos agentes chegou-se às suas principais ações, que se encontram registradas nas fontes mencionadas.

Igualmente indispensáveis foram os levantamentos das informações estatísticas realizadas em várias fontes secundárias oficiais e na bibliografia coligida, que, após tratamento adequado, foram aplicadas à demonstração das asserções, por meio de tabelas e gráficos; as ilustrações - mapas e imagens - foram produzidas pelo próprio autor deste estudo. Os mapas derivaram de informações quantitativas e qualitativas retiradas de origens diversas, expressas na fonte das respectivas ilustrações.

O livro divide-se em quatro partes e inclui uma breve conclusão. Na primeira parte, discute-se as contribuições teóricas mais importantes acerca do conceito de território, que também envolve uma discussão sobre o conceito de poder, na tentativa de ressignificar o conceito de território, tão caro à ciência geográfica e por extensão ao conjunto das ciências humanas e à política. A segunda parte é dedicada à análise do processo de surgimento e da posterior dissolução de um território no Recôncavo Baiano durante o momento em que os usineiros de açúcar desta região eram os agentes sociais de maior visibilidade política até o fim da década de 1950. Na terceira parte, o esforço é para explicar o processo de construção de um novo território numa parte do Recôncavo Baiano, organizado em torno das demandas de uma grande corporação estatal de petróleo - a Petrobras -, que também passa a desenvolver ao mesmo tempo, seu processo interno de reestruturação organizacional para transformar-se numa organização empresarial complexa, multifuncional e multilocalizada. Na quarta parte discute-se os conceitos de gestão e de grande corporação e tenta-se explicar de que maneira a Petrobras implementou o seu processo de gestão de seu território no Recôncavo Baiano, que resultou por erigir uma configuração territorial específica, materializando-se nas relações de trabalho contratuais, na organização do trabalho em fluxo contínuo baseado na grande indústria, na emergência de uma classe operária industrial moderna e no próprio processo de urbanização em seus aspectos mais amplos. 



\section{Ressignificando o conceito de território}





\section{Ressignificando o conceito de território}

O termo território refere-se a uma categoria geográfica elaborada historicamente, e constitui um conceito consagrado nas ciências humanas.

O vocábulo território é essencialmente polissêmico. Genericamente é utilizado para designar uma extensão da superfície da Terra, na qual grupos sociais, instituições e indivíduos entram em disputa pela afirmação de seus interesses, semelhante ao que ocorre entre os animais de uma mesma espécie. Certamente, essa é uma assertiva com a qual não se pode concordar nos dias de hoje, mas é a que prevalece. Entende-se que essa polissemia implica inconsistências acerca do significado do conceito de território, induzindo alguns (pessoas, pesquisadores e agentes de Governo) a entenderem que a simples existência de uma parcela da superfície terrestre ou uma área de terra é o próprio território; outros crêem que a existência do território é confirmada com a presença do Estado; outros acreditam que território é o mesmo que espaço geográfico; outros, ainda, o relacionam a uma certa dimensão espacial e durabilidade temporal; e outros, o mais grave, têm no território uma forma de controle de uns agentes sociais sobre outros. Contudo, nas falas e nos textos, predomina a idéia de relações de poder entre os distintos agentes, que se acredita ser a premissa subjacente ao referido conceito.

Estudos desenvolvidos a partir da década de 1980, por pesquisadores das ciências humanas, sobretudo da geografia, buscam superar a vinculação biológica que permeia o entendimento sobre o território, com a valorização das ações sociais. Entretanto, a compreensão desse conceito ainda oculta princípios que, forçosamente, remetem a territorialidade, que são as ações entre os agentes sociais, ao nível de relações hierarquizadas e com forte apelo sintagmático.

Os territórios, como o locus de manifestação das materialidades sociais em meio às forças universalizantes do sistema capitalista, resultam no que Santos, M. (1994) designa de uma "forma impura". Nesse sentido, a territorialidade humana aparece como o conjunto de relações mediadas pelo poder entre os distintos agentes sociais (Estado/Governo, empresas, instituições sociais, ..., cidadãos), que se interessam por algum objeto comum localizado numa dada porção do espaço geográfico. A territorialidade implica a capacidade desses agentes de produzirem e/ou organizarem sistematicamente territórios, segundo um projeto orientado por um agente hegemônico (GRAMSCl, 2000).

Aqui se entende que a territorialidade humana constitui tão-somente uma estratégia para o desenvolvimento e/ou defesa de algum tipo de interesse de agentes sociais específicos. Da mesma maneira, o termo território não significa ser propriedade dos agentes sociais, porque exprime apenas uma relação política 
e não patrimonial, apesar de, etimologicamente, o referido termo derivar do latim territorium que significa terra pertencente a alguém.

Os territórios são produzidos e podem ser desfeitos sem que seja necessária sua vinculação com o Estado ou o Governo. Perlongher (1987), Godoi (1998) e Silva, S.; Silva, B. (2003) dão bons exemplos de territórios que se organizaram sem a participação do Estado ou do Governo. O primeiro autor estudou a prostituição viril no centro da cidade de São Paulo; a segunda autora analisou as relações sociais entre indivíduos de um mesmo tronco familiar em torno da propriedade, ocupação e uso da terra rural no sertão do Piauí; e os dois últimos autores estudaram as ações de uma associação de pequenos produtores rurais na região sisaleira do estado da Bahia. Sobre essa temática os exemplos são numerosos.

Assim, a territorialidade humana e seu substrato material, com todas as características naturais e as socialmente criadas são termos que encerram uma única assertiva - resultam de relações sociais desenvolvidas entre os diferentes agentes, mediadas pelo poder e projetadas numa dada porção do espaço geográfico que se torna território.

Dessa maneira, se da parte de um agente hegemônico que se insere numa dada porção do espaço geográfico e entra em relações com os demais agentes existentes não houver uma intenção sistemática de reproduzir o território específico durante uma fração de tempo relativamente duradoura, o mesmo somente irá durar o tempo de cessar a energia que o fez surgir.

Todavia, apenas afirmar que o território resulta de relações de poder entre os agentes não adianta muito se se pretende avançar com o significado do referido conceito, pois, seja pela antiga forma de compreendê-lo, a partir da geopolítica ratzeliana, seja por meio de sua crítica, com as contribuições elaboradas por Raffestin (1993), Sack (1986) e Souza, M. (1995) dentre outros autores, a relação de poder é essencial para o conceito de território.

Para esses autores a idéia de poder é central, permeia toda a obra de Ratzel (MENDOZA; JIMÉNEZ; CANTERO, 1982; MORAES, 1990). Em Raffestin (1993, p. 58) é clara a combinação entre poder e território quando o autor escreve: "O território não é menos indispensável, uma vez que é a cena do poder e o lugar de todas as relações [...]". No mesmo sentido, Sack (1986, p. 26) torna explícito a indissociabilidade entre poder e territorialidade ao afirmar: "Human spatial relations are the results of influence and power. Territoriality is the primary spatial form takes". ${ }^{1}$ Por fim, Souza, M. (1995, p. 78, grifos do autor) grafa, "[...] o território, objeto deste ensaio é fundamentalmente um espaço definido e delimitado por e a partir de relações de poder". Dessa maneira, acredita-se que

\footnotetext{
1 "As relações humanas no espaço são o resultado da influência e do poder. A territorialidade é primeiramente forma espacial" (tradução nossa).
} 
revisitar os conceitos de poder e território é essencial para uma contribuição aos estudos sobre essa temática.

Tem-se por princípio que o que fundamenta uma relação de poder entre os agentes envolvidos numa dada relação social é o consenso e nunca a submissão (ARENDT, 1994), apesar de ser um tipo de relação que é necessariamente movida por assimetrias, as quais se manifestam por meio de conflitos de interesses e nunca por igualdades, daí a menção à existência de um agente hegemônico que exerce o papel de liderança.

Considera-se como ação de liderança qualquer tipo de ação desenvolvida por um determinado agente social legitimamente capaz de assumir tal posição, disso excluindo-se qualquer referência a um ato de relação vertical, de comando/obediência ${ }^{2}$. Nesse sentido, os territórios são reproduzidos segundo um processo de cooperação. A cooperação, segundo Marx (1988, v. 1, p. 374) é "[...] a forma de trabalho em que muitos trabalham juntos, de acordo com um plano, no mesmo processo de produção ou em processos de produção diferentes mas conexos."

Das ações de liderança de um agente hegemônico num dado território resulta que o conteúdo que atribui identidade aos territórios reflete mais fortemente as materializações dos interesses dos agentes hegemônicos que coordenam legitimamente o consenso formado tacitamente ou não em torno de um cronograma de objetivos, mediado pelas perspectivas desses agentes. Entretanto, cada um dos agentes envolvidos busca, de alguma maneira, defender também seus respectivos interesses e almeja suas ambições, do contrário não existe consenso, mas sim a coação, dominação, controle ou termos correlatos que, no fim, significa a supressão da autonomia (CASTORIADIS, 1982) dos demais agentes envolvidos na relação social.

A contemporaneidade tem sido marcada, cada vez mais, por ações desenvolvidas pelos movimentos sociais organizados que reclamam das autoridades governamentais constituídas maior participação e autonomia na cena política, desde a escala do lugar até a mundial. Nessa senda, os agentes sociais, sejam quais forem, muitas vezes, têm apresentado seus pleitos segundo atitudes cada vez mais despojadas de relações de comando/obediência. Isso se deve, em parte, ao avanço do regime de Governos democráticos em várias partes do mundo, e a um constante e progressivo aumento da permissividade e conquista da participação dos movimentos sociais organizados em decisões que afetam a ordem social,

\footnotetext{
${ }^{2} \mathrm{O}$ conceito de legitimidade baseia-se em Lafer, que elaborou o prefácio da obra Poder e legitimidade. O autor assinala que, "A legitimidade é fundamentalmente avaliativa, requerendo o concurso da opinião pública, que no espaço da palavra e da ação, julga dos títulos em nome dos quais o poder é exercido" (FARIA, 1978, p. 12-13).
} 
econômica, política e ecológica em muitos países ${ }^{3}$. Em outras palavras, já se nota contemporaneamente que há uma tendência geral no sentido de que um único agente, seja ele qual for, já não impõe mais aos demais suas opiniões, paixões e desejos, pelo menos abertamente, o que é comum nos regimes tirânicos de direita e/ou de esquerda.

Dito isso, se a própria realidade empírica da sociedade em que se vive tem demonstrado rejeição a relações baseadas em comando/obediência, por que então, na análise científica das relações de poder entre distintos agentes, ainda se insiste em apelar para esse tipo de interpretação, incorrendo em grave equívoco ao não considerar os reais significados que se escondem por detrás de uma relação de dominação, de controle ou de comando/obediência como adverte Machado (1995, p. 22):

Precisamente nas organizações sócio-econômico-espaciais é que aparece também a conotação negativa, essencialmente política, do ato de controlar, na medida em que é identificado como ato de evitar transformações que ameacem a estrutura vigente de poder, ela mesma tomado como algo socialmente negativo (grifos da autora).

Apesar de todo o cuidado com o significado político e rigor científico aplicados pelos estudiosos do tema em torno da idéia de poder, muitos continuam a reproduzir idéias como, dominação, controle e termos correlatos, significando o mesmo que poder.

Os fatos da história social moderna e contemporânea são suficientes e bastantes, quando evidenciam que milhões de pessoas, em distintas partes do mundo, viveram e em alguns casos vivem ainda há várias gerações sob o domínio ou controle de outras, como exemplo pode-se lembrar: os povos indianos, chineses, escoceses e sul-africanos sob o controle inglês; depois os chineses sob a revolução comunista; o povo chileno sob o controle da ditadura do general Pinochet; a dominação da ditadura militar (1964-1985) no Brasil; e, por fim a invasão do Iraque, em 2002, pelas tropas norte-americanas e seus liderados, desconsiderando acordos internacionais, para não falar de fatos mais grotescos. Certamente esses não são exemplos de relações de poder, mas de pura dominação ou controle.

\footnotetext{
${ }^{3}$ Dias, R. (1997) oferece um artigo intitulado Gestão pública e meio ambiente: o caso da CESP e as duas usinas termoelétricas em São Paulo, que traz à discussão a participação dos movimentos sociais organizados nas decisões que afetam diretamente os interesses coletivos, mesmo com o enfrentamento dos interesses do Estado ou do Governo. Nesse artigo o autor analisa o processo de reação popular que embargou peremptoriamente as intenções da Companhia Energética de São Paulo (Cesp) em tentar instalar uma usina termelétrica no município de Paulínia (1989/1992) e outra em Mogi-Guaçu (1992/1993), no estado de São Paulo.
} 
Diante da indistinção do significado político subjacente a esses termos entende-se ser necessário, ainda que brevemente, explorar as principais contribuições sobre o conceito de poder.

Acredita-se como Arendt (1994), que a insistência na repetição dessa maneira de entender o poder como relação vertical advém da situação histórica de o homem querer sempre dominar o próprio homem, e a polissemia embutida no termo poder cumpre bem certos objetivos conjunturais principalmente dos governos e genericamente dos agentes sociais não governamentais que possuem os meios e as condições de fazer com que os demais agentes atendam seus interesses, seja por meio da persuasão, ou da coação. Nessa perspectiva destaca Arendt (1994, p. 32): "Se a essência do poder é a efetividade do comando, então não há maior poder do que aquele emergente do cano de uma arma, e seria difícil dizer 'em que medida a ordem dada por um policial é diferente daquela dada por um pistoleiro" ".

E insiste a autora:

Por detrás da aparente confusão subjaz a firme convicção à luz da qual todas as distinções seriam, no melhor dos casos, de pouca importância: a convicção de que o tema político mais crucial é, e sempre foi, a questão sobre 'quem domina quem'. Poder, vigor, força autoridade e violência seriam simples palavras para indicar os meios em função dos quais o homem domina o homem; são tomados por sinônimos porque têm a mesma função (ARENDT, 1994, p. 36, aspas da autora).

\section{Abordagens correntes sobre o conceito de poder}

Modernamente, a abordagem corrente sobre o conceito de poder baseia-se nas idéias sistematizadas pelo sociólogo Max Weber que é apenas um dos caminhos teóricos possíveis e representava um certo momento histórico - o final do século XIX e o início do século XX -, com todas as demandas decorrentes das dinâmicas de uma nova ordem política, social e econômica mundial emergente, associada ao expansionismo de alguns Estados-nacionais europeus mais fortes, em especial a colonização do continente africano, e internamente, nesses países, a luta política entre as classes sociais para assumir e/ou manter a posição de mando, e tudo isso precisava ser legitimado também cientificamente. Esse caminho atendia aos interesses, tanto das burguesias nacionais, como das classes subalternas que aspiravam a tomada do comando em seus respectivos países.

Conforme Weber (1991, p. 33), "[...] o Poder significa toda probabilidade de impor a própria vontade numa relação social, mesmo contra resistências, seja qual 
for o fundamento dessa probabilidade". Ora, dessa maneira, o poder seria propriedade de um indivíduo ou agente que dispõe dos meios e das condições suficientes para impor aos demais indivíduos e organizações que participam de uma relação social, sua vontade, seus desejos e paixões; no limite, pelo caráter funcional dessa definição, o exercício do poder, nessas bases, pode-se tornar, em certas condições, um claro convite a variadas formas de coação, além de alimentar os esquemas de dominação e controle social e político, como, mas que nunca, a história social contemporânea tem evidenciado.

Destarte o poder é entendido como uma relação unidimensional, apesar da larga defesa que se faz dessa via de se compreender e exercitar o poder, mas que nos dias de hoje parece anacrônica, tendo em vista a recusa mais veemente da sociedade à tirania. É de se observar que Weber não defendia a tirania, mas sua formulação se baseava na realidade de uma época em que o exercício da dominação, da violência legitimada estava sob o monopólio dos Estados-nação. ${ }^{4}$

Para Poulantzas (1986) que era um intelectual orgânico do movimento político de esquerda, o poder somente existe na luta de classes e pertence à classe que assume a posição dominante, em virtude de uma certa homogeneidade de interesses de classe envolvida numa estrutura. Para o autor o poder corresponde "[...] a capacidade de uma classe social de realizar os seus interesses objetivos específicos" (POULANTZAS, 1986, p. 100).

É de se notar que o autor empobrece o significado da categoria poder ao reduzi-lo à luta de classes e a invocar uma homogeneidade de interesses de classe difícil de se verificar, haja vista as constantes disputas de posições e cizões entre os grupos constituintes das distintas classes sociais. Será que no interior das classes sociais não coabitam interesses conflitantes? Pode-se exemplificar que nos países onde o socialismo foi implantado as incontáveis formas de manifestação de conflitos somente não ganhavam a dimensão pública por causa do "medo", do temor à repressão de uma sociedade policialesca. De outra maneira, como ficam as demandas dos grupos sociais minoritários que não possuem organização estruturada em classe? Essas são questões iniciais que dificultam a operacionalização da concepção de poder proposta por Poulantzas (1986), num momento em que a condição humana (ARENDT, 1981) requer e exige a livre expressão da palavra e das ações.

\footnotetext{
${ }^{4}$ A obra de Weber é vasta e consistente, especialmente quando o autor trata dos conceitos, os quais são finamente elaborados e resultam de interpretações criteriosas da realidade social de sua época. Sua obra é rica e de longo alcance intelectual, tanto que desde a sua publicação, que foi traduzida para vários idiomas, ele vem formando escolas em vários campos do saber científico, principalmente na sociologia. Porém, a história social, como entendida também por Weber é dinâmica e os conceitos não são eternos, eles podem ser ressignificados e/ou sofrer a concorrência de um outro que pode emergir como possibilidade de alternativa, no caso, a definição de poder proposto por Arendt.
} 
Noutra perspectiva, Foucault (1999) se esforça em discutir o conceito de poder a partir da idéia de como ele é exercido e em que condições. Nesse sentido, o autor critica as concepções doutrinárias e marxistas que têm em comum o economicismo, servindo essencialmente para favorecer as relações de produção e a dominação de classe. O autor conclui que

\footnotetext{
“[...] o poder não se dá, não se troca nem se retoma, mas se exerce, só existe em ação, como também da afirmação que o poder não é principalmente manutenção e reprodução das relações econômicas, mas acima de tudo uma relação de força" (FOUCAULT, 1999, p. 175).
}

A novidade trazida por Foucault reside em considerar o poder como não sendo de propriedade de nenhum indivíduo ou agente, ele existe e é exercido. Contudo, o autor encara as relações de poder entre os agentes de forma absoluta e em sentido disciplinar.

Contrapondo-se a toda e qualquer possibilidade de tutela e/ou cerceamento da ação e do discurso, ou seja, da vida pública que é própria da sociedade humana, Arendt (1994) entende que o poder emerge da relação de consenso entre os agentes sociais, e por isso, a violência é descartada. A autora adverte que não existe poder puro e nem violência pura. A violência poderá até ser utilizada em alguma medida, mas apenas de forma instrumental e autorizada e, além disso, a violência jamais pode ser entendida como pressuposto do poder.

Para Arendt (1994, p. 36):

O poder corresponde à habilidade humana não apenas para agir, mas para agir em concerto. O poder nunca é propriedade de um indivíduo; pertence a um grupo e permanece em existência apenas na medida em que o grupo conservase unido. Quando dizemos que alguém está 'no poder', na realidade nos referimos ao fato de que ele foi empossado por um certo número de pessoas para agir em seu nome.

Essa assertiva indica que o poder não é hierárquico e tampouco que um agente tenha mais poder que outro; indica também que o poder é tanto mais afirmado quanto maior for o número dos agentes que emprestam seus nomes favoravelmente a uma dada ação do grupo com o qual se relacionam. Segundo Arendt (1994), o poder existe e é próprio das relações sociais, não precisando, portanto, de justificação; o que precisa de justificação para seu uso é a violência. Essa proposta de poder defendida por Arendt (1994) implica que o mesmo é garantido pela legitimidade das ações dos agentes, autorizadas em nome do consenso. A elaboração sobre o poder feita por Arendt (1994) apresenta-se como uma criação intelectual avança- 
da, baseada em reflexões de problemas concretos do tempo atual, que reage à sempre presente tendência à negação da pluralidade da vida social pública.

\section{A emergência e estado atual do conceito de território}

Durante o século XVIII, alguns filósofos já haviam sugerido a emergência e aplicação do termo território, sem, contudo defini-lo. Montesquieu (1973), em 1748 , foi um dos que tratou do assunto território de maneira direta, no capítulo XXII do seu livro "O espírito das leis". Para ele, o território surge como uma parte do espaço geográfico ocupado e usado por uma dada formação econômico-social. Com entendimento semelhante a Montesquieu (1973) sobre o território, Voltaire (1978), no mesmo período, ao tratar da guerra, no dicionário filosófico, apresenta a noção de território como sendo terra de domínio de um príncipe. Em 1857/8, Marx (1986) prenuncia o conceito de território em seus escritos sobre as formações econômicas pré-capitalistas.

De acordo com Marx (1986, p. 87), a noção de território estaria dada em sua declaração, "[...] o que faz com que uma região da terra seja um território de caça é o fato das tribos caçarem nela [...]." Com isso, o autor aponta a condição de suporte da vida material de um dado grupo social que se apropria e usa uma parte do espaço geográfico, em um período historicamente datado. É evidente que Marx (1986) não estava preocupado em compreender o território em si, mas sim as formações econômico-sociais pré-capitalistas, que forneceria elementos de análise para seu trabalho de maior fôlego - O capital.

Para o autor, o território pode apresentar uma certa fixidez ou mobilidade dependendo do uso que os grupos sociais fazem dele, o que é determinado pela forma de organização social, política e econômica desses grupos sociais. Mas isso não implica qualquer tipo de afeição pelo substrato material, mas tãosomente, a apropriação das possibilidades materiais de reprodução da vida.

O conceito de território somente emergiu da condição de noção a partir da sistematização dos trabalhos de Ratzel (MORAES, 1990), em fins do século XIX, e estritamente vinculado ao Estado-nação que provê os meios de sua expansão e defesa, segundo sua potência. Portanto, o território torna-se um meio pelo qual o Estado-nação também se fortalece, retirando dele as condições para implementar o seu vigor econômico, cultural e bélico, como potência temível, por meio de relações sociais de dominação e de violência.

É de Ratzel a seguinte definição de território: "[...] uma determinada porção da superfície terrestre apropriada por um grupo humano" (MORAES, 1990, p. 23). Na concepção do autor o que fica patente é a idéia de conquista, domínio e, 
por fim, de propriedade de uma dada porção do espaço geográfico, que se desenvolve ao nível das relações entre os seres do mundo natural. Esse pensamento decorre do fato de que em seu tempo - fim do século XIX -, o autor estava profundamente influenciado pelas idéias darwinistas e pelo processo expansionista e belicista do Estado germânico depois de sua unificação.

Um dos primeiros autores que se preocupou em descolar a idéia de território, do darwinismo e das ações belicistas dos Estados foi Gottmann (1973). O autor apresenta uma análise pormenorizada sobre o significado do termo território. Ele baseia sua abordagem no processo de desenvolvimento histórico, político e cultural da sociedade humana, relacionando os eventos da formação dos territórios com a satisfação das necessidades de segurança, soberania nacional e prosperidade econômica, política, social e cultural dos povos.

Contrariamente a Ratzel, mas ainda preso à idéia primordial da existência do Estado-nação como condição para o surgimento dos territórios, Gottmann (1973) concebe o território como sendo o substrato onde o Estado-nação exerce sua soberania. Para ele, o território emerge junto com a soberania nacional. Segundo o autor, o território não é um conceito absoluto e nem abstrato, ele encerra um conteúdo essencialmente relacional, envolve a noção de ocupação e uso de uma dada porção do espaço geográfico, que pode ser identificada implicitamente na definição proposta por ele:

The concept of territory, though geographical, because it involves accessibility and therefore location, must not be classified with physical, inanimate phenomena. Although its Latin root, terra, means 'land' or 'earth' the word territory conveys the notion of an area around a place; it connotes an organization with an element of centrality, which ought to be authority exercising sovereignty over the people occupying or using that place and the space around it (GOTTMANN, 1973, p. 5). ${ }^{5}$

A elaboração de Gottmann (1973) é refinada e bastante fundamentada - uma tese de difícil contestação -, porém, com tantas possibilidades, não se pode querer ou simplesmente aceitar que territórios somente possam existir sob a condição de existência de um Estado-nacional, o que implicaria, também, que a experiência do território somente ocorreria no singular, ignorando a toda riqueza da realidade.

Raffestin (1993, p. 144) elabora uma reflexão singular sobre o território, entendendo-o como "[...] um espaço onde se projetou um trabalho, seja ener-

\footnotetext{
${ }^{5} \mathrm{O}$ conceito de território, embora geográfico, porque envolve acessibilidade e localização, não deve ser classificado como fenômeno físico, inanimado. Embora sua raiz latina, 'terra' signifique 'terra', a palavra território transmite a noção de uma área ao redor de um lugar; conota uma organização com elementos de centralidade, que deveria ser a autoridade que a soberania exerce sobre as pessoas que ocupam ou usam o lugar e o espaço em seu redor (GOTTMANN, 1973, p. 5, tradução nossa).
} 
gia e informação, e que, por conseqüência, revela relações marcadas pelo poder". Para o autor, "A territorialidade aparece então, como constituída de relações mediatizadas, simétricas ou dissimétricas com a exterioridade" (1993, p. 161). O autor é enfático ao referir-se à territorialidade explicando que ela não deve ser vista como uma simples ligação com o espaço geográfico; o autor esclarece que "[...] a territorialidade se inscreve no quadro da produção, da troca e do consumo das coisas" (RAFFESTIN, 1993, p. 161).

Em sua contribuição teórica sobre a territorialidade e o território Raffestin (1993) esforçou-se em esclarecer que território e espaço geográfico não são a mesma coisa; o espaço geográfico tem existência anterior ao território e é sobre ele que se organiza o território. O autor enfatiza o caráter do poder que é essencialmente multidimensional, mas estava sucumbido ideologicamente e condicionado a uma concepção unidimensional, ao alcance exclusivamente do Estadonação.

Sem dúvida, é bastante meritória a abordagem que Raffestin (1993) desenvolve para entender a territorialidade e o território, principalmente porque o autor propôs uma outra fundamentação à compreensão do tema, e que contribuiu para erigir avanços substanciais sobre a temática.

No entanto, Raffestin (1993) não atenta para distinguir poder de dominação, apesar de optar por trabalhar com o conceito de poder apresentado por Foucault (1999), talvez seja aí que resida uma das fontes de ambigüidade, pois o autor, pelo que se apresenta, somente apreendeu a parte problemática da formulação de Foucault (1999) - o sentido absoluto e disciplinar das relações sociais. Assim escreve o autor: "[...] o poder visa o controle e a dominação sobre os homens e sobre as coisas" (RAFFESTIN, 1993, p. 58). Inicialmente, ele se propõe a utilizar a proposta de poder desenvolvida por Foucault, mas, na verdade, como vimos anteriormente, é na idéia de poder de Weber (1991) que ele efetivamente se inspira. Para Raffestin (1993), poder, controle e dominação são termos equivalentes, o que implica necessariamente uma relação definida por ações de comando/ obediência. Esse tipo de relação social retira a autonomia dos agentes envolvidos nela, exceto o que domina, o agente sintagmático ou outro adjetivo atribuível àqueles que comandam. Isso é patente em suas afirmações,

\footnotetext{
As 'imagens' territoriais revelam as relações de produção e consequentemente as relações de poder, e é decifrando-as que se chega à estrutura profunda. Do Estado ao indivíduo, passando por todas as organizações pequenas ou grandes, encontram-se atores sintagmáticos que 'produzem' o território (RAFFESTIN, 1993, p. 152).
}

Ora, com isso, o autor apenas desloca o centro da dominação do Estado/Governo para outros agentes particulares, seja um indivíduo ou uma organização, enquanto 
"atores sintagmáticos", ou seja, aqueles que determinam o que podem ou não fazer os agentes subordinados; depois, Rafesttin (1993) reduz a territorialidade a fenômenos relacionados exclusivamente à órbita econômica - produção, circulação, troca e consumo de bens e serviços -, quando, na verdade abundam exemplos de territorialidades ligados a gênero, etnia e idade dentre outros.

Assim, reduzir a territorialidade humana a um fenômeno estritamente econômico para distinguir da territorialidade animal contribui pouco para compreensão desse fenômeno.

A rigor são esses os principais inconvenientes da formulação de Raffestin (1993) que confirmam a polissemia embutida no conceito de território, fruto de sua compreensão confusa do conceito de poder e de uma necessidade míope de afirmação da geografia como a disciplina que monopoliza o tema.

Após a publicação da versão original da obra de Raffestin em 1980, foi sem dúvida o estudo de Sack, publicado em 1986, que contribuiu com os maiores avanços sobre o conceito de territorialidade e seu substrato material - o território - num plano já desvinculado das amarras do Estado-nação, proposto por Raffestin (1993).

Sack (1986, p. 19) define a territorialidade como a "[...] attempt by an individual or group to affect, influence, or control people, phenomena, and relationships, by delimiting and asserting control over a geographic area". ${ }^{6}$

Dentre todas as contribuições que Sack (1986) apresenta para compreensão do conceito de território, as mais importantes referem-se a três questões singulares.

Primeiramente, reforça a distinção entre a territorialidade humana e a territorialidade animal. Enquanto para os humanos a territorialidade significa uma estratégia de ação dos agentes frente a seus interesses num dado território, ou seja, passa pela órbita da ação política, para os animais a territorialidade resulta de instintos fundados somente em ações de natureza biológica.

Segundo, os territórios não possuem uma dimensão fixa, variam de tamanho e inclusive podem ser móveis, a exemplo dos navios de distintas nacionalidades. Os territórios também possuem uma duração temporal variável, isto é, da mesma maneira que existem num dado momento, noutro poderão deixar de existir.

Por último, como os territórios são porções do espaço geográfico organizados em torno da liderança de um agente hegemônico, então, se pode concluir que vários territórios podem ser estruturados concomitantemente pelo mesmo agente. Acredita-se, porém que esses territórios não apresentam a mesma configuração territorial. Essa última característica levantada por Sack (1986) é uma das mais importantes, pois permite a abordagem metodológica do território articulado em

\footnotetext{
6 "[...] tentativa por um indivíduo ou um grupo para afetar, influenciar ou controlar pessoas, fenômenos e relações, pela delimitação e afirmação do controle sobre uma área geográfica" (1986, p. 19, tradução nossa).
} 
rede, pela possibilidade de um mesmo agente projetar suas ações em vários territórios ao mesmo tempo. Essa abordagem é sumamente importante para a análise dos fenômenos sócio-territoriais por meio das redes geográficas. ${ }^{7}$

Essas contribuições tornam mais fácil a compreensão do conceito de territorialidade e de território, pois sepultam de uma vez por todas a idéia de que o território e a territorialidade são determinados exclusivamente pela presença do Estado-nação.

Da mesma maneira que existem territórios independentemente das ações dos Estados-nação, também se formam os territórios representados pelo exercício da soberania dos Estados-nação, cuja relação de poder com a sociedade se exprime no ambiente político do Congresso Nacional dos respectivos países, em se tratando de democracias. Do mesmo modo, as áreas de jurisdição dos Governos em suas distintas escalas de ação e das autarquias federais, estaduais (provinciais) e municipais que agem em dadas partes dos países para promover o progresso social e econômico em regiões economicamente deprimidas são também territórios.

Nesse sentido, dois exemplos de territorialidade dos Estados-nação podem ser destacados: a Tennessee Valley Authority (TVA), nos Estados Unidos da América do Norte, e no caso brasileiro, a extinta Superintendência do Desenvolvimento do Nordeste (Sudene), e demais órgãos governamentais que agem em todo o Brasil e os das distintas nacionalidades em várias partes do mundo.

Vale destacar que em nenhum desses dois exemplos o Estado/Governo utilizou mecanismos de coação na inter-relação com os demais agentes envolvidos, ao contrário, as mediações políticas é que foram privilegiadas. Por exemplo, no embargo da construção das usinas termelétricas nos municípios de Paulínia-SP, em 1989/1992, e Mogi-Guaçu-SP, em 1992/1993, em decorrência de ações populares contra a Companhia Energética de São Paulo (Cesp), apesar de ter sido desfavorável para a empresa, nem o Governo do estado de São Paulo e nem a própria empresa utilizaram recursos coercitivos para tentar anular a Lei, de iniciativa popular, aprovada nas respectivas Câmaras Municipais, a qual proíbe peremptoriamente a instalação desse tipo de empreendimento nos referidos municípios (DIAS, R., 1997).

Esses exemplos servem para reforçar o entendimento de que a territorialidade é um fenômeno produzido por vários tipos de agentes sociais que se relacionam entre si, sob a liderança de um determinado agente que goza de legitimidade no consenso firmado com os demais.

O estudo de Sack (1986) é de uma riqueza teórica e experimental significativas. Contudo, assim como Raffestin (1993), Sack (1986, p. 27, 52-53) também admite a relação de dominação como sinônimo de relação de poder, como está

\footnotetext{
${ }^{7}$ Sobre o conceito de redes consultar Dias, L. (1995a) e Santos, M. (1997).
} 
explícito em sua definição e nos argumentos que aparecem em toda sua obra, "[...] who is controlling whom and for what purposes". ${ }^{8}$

Corrêa (1994) apresenta uma discussão importante sobre a territorialidade de uma grande empresa no Brasil - a companhia de cigarros Souza Cruz. O autor se empenha em distinguir território de espaço geográfico e explora o termo territorialidade e desterritorialidade, dentre outros, relacionados ao conceito de território. A territorialidade é, então, explicada como sendo o resultado de ações materiais e imateriais empreendidas pelos agentes com vistas a permitir-lhes a conquista de um dado território e sua posterior permanência no mesmo, ou seja, a sua reprodução; a desterritorialidade significa para um dado agente a perda do território, mas que poderá ser retomado no futuro. $\mathrm{O}$ autor explica que, ao se apropriar de um território, o agente não está tornando-se proprietário do mesmo, mas tão-somente buscando prover as necessidades de sua reprodução enquanto agente social, que desenvolve interesse sobre um objeto específico ali localizado.

O texto é importante porque exemplifica o processo de territorialização de uma empresa, como um estudo de caso. No entanto, Corrêa (1994) também faz uso do termo controle, pois seu entendimento sobre o conceito de territorialidade e de território é influenciado por Sack (1986), como afirma o próprio autor.

Buscando dirimir algumas dúvidas sobre o conceito de território, Souza, $\mathrm{M}$. (1995), outro geógrafo brasileiro, reabre em alto nível o debate sobre esse conceito. Acredita-se que o grande mérito do autor é, por um lado, ter trazido para a discussão sobre o conceito de território, o conceito de poder com as contribuições teóricas desenvolvidas pela cientista política Arendt (1994), e, por outro lado, tentar sistematizar alguns exemplos de territorialidades associadas à antropologia e à sociologia.

Como os autores anteriores, Souza, M. $(1995$, p. 87$)$ se esforça para esclarecer o que é o território ao assinalar que "[...] territórios, que são no fundo antes relações sociais projetadas no espaço que espaços concretos [...]." O autor também salienta que os territórios existem e que não há nenhuma lei que determine que eles sejam uns justapostos aos outros. Ao contrário, dependendo dos tipos de territorialidades, vários territórios podem, inclusive, superpor-se sem nenhuma ordem prévia e, tampouco, nenhum deles tem obrigação de fazer coincidir o tamanho de sua área com outro qualquer que esteja sobreposto ou anteposto, além da possibilidade de serem móveis, como já havia destacado Sack (1986) e, antes dele, Marx (1986).

Se Raffestin (1993) e Sack (1986) complicam um pouco o entendimento do conceito de território ao se prenderem à idéia de controle/dominação como equi-

8 "[...] quem controla quem e para que propósitos?" (SACK, 1986, p. 27, 52- 53, tradução nossa). 
valentes ao poder, Souza, M., (1995) também segue na mesma direção, pois o mesmo não atentou para a sutileza da indistinção de uma relação social de poder, de uma relação de dominação. Isso, em decorrência do fato de o autor se preocupar em tentar encontrar o agente que exerce a função de dominação no território, tal como ele mesmo explicita,

\begin{abstract}
O território, objeto deste ensaio, é fundamentalmente um espaço definido e delimitado por e a partir de relações de poder. A questão primordial, aqui, não é, na realidade, quais são as características geoecológicas e os recursos naturais de uma certa área, o que se produz ou quem produz em um dado espaço, ou ainda quais as ligações afetivas e de identidade entre um grupo social e seu espaço. Estes aspectos podem ser de crucial importância para a compreensão da gênese de um território ou do interesse por tomá-lo ou mantê-lo, como exemplificam as palavras de Sun Tzu a propósito da conformação do terreno, mas o verdadeiro Leitmotiv é o seguinte: quem domina ou influencia e como domina ou influencia esse espaço? (SOUZA, M., 1995, p. 79, grifos do autor).
\end{abstract}

Do exposto até aqui evidencia-se que o autor, como os demais, nutriu sua idéia sobre o poder no pensamento de Weber (1991), o qual é um caminho possível para interpretar a realidade social. Porém, o que pesa é a opção diametralmente oposta à idéia de poder defendida por Arendt (1994), quando o referido autor afirma que,

A conceituação acima resumida é, como se verá mais adiante na seção 2, de um
interesse especial para o presente artigo, por ampliar a idéia de poder e simultanea-
mente libertá-la da confusão com a violência e da restrição à dominação, permitindo
assim conjugar as idéias de poder - e, por extensão, território - e autonomia (SOU-
ZA, M., 1995, p. 80, grifos do autor).

Cabe ressaltar mais uma vez que, para Arendt (1994), poder e violência, dominação, controle ou comando são conceitos inconciliáveis, porque enquanto o primeiro privilegia a pluralidade e a vida ativa pública, os demais as reprime. Sendo assim, o exemplo de território apresentado por Souza, M. (1995) evidenciado pelas materializações da territorialidade do tráfico de drogas nas favelas cariocas não é outra coisa, senão, e infelizmente, o ambiente da tirania e da violência perpetrados pelos diversos bandos de criminosos, onde as pessoas de bem são vigiadas pelos "olheiros" dos traficantes, são humilhadas e silenciadas, não restando possibilidade para a ação e para o diálogo autônomos, conforme defende Arendt (1981), em A Condição humana. Entende-se, dessa maneira, que, ao mesmo tempo em que o referido autor ampliou substancialmente os horizontes em relação ao entendimento sobre o conceito de território, também criou uma fonte de dúvidas sub-reptícia. 
Dentre outros autores, na ordem cronológica, uma das últimas contribuições fundamentais sobre o conceito de território foi apresentada por Santos, M.; Silveira (2001, p. 19) como sendo "[...] uma extensão apropriada e usada". Essa definição de território é válida, no sentido de relativizar o fenômeno da territorialidade em uma dada porção do espaço geográfico que se torna território, como referência de uso de certos objetos por dados agentes sociais em meio a uma "totalidade parcial".

Todavia, a proposta apresentada por Santos, M.; Silveira (2001) e seus colaboradores, pela própria perspectiva da abordagem do assunto, não contempla relações de poder, o que a aproxima mais do conceito de espaço geográfico. Os autores antecipam que para eles o território é sinônimo de espaço geográfico; porém, é nesse ponto que se acredita residir a ambigüidade do conceito na perspectiva dos autores.

Por fim, Haisbaert (2006) desenvolve uma longa e acurada discussão, muito proveitosa e oportuna, sobre o conceito de território, sobretudo, pela abordagem sofisticada, com o exemplo da idéia de multiterritorialidade. Nos dias de hoje, segundo o autor, a multiterritorialidade significa a possibilidade de os agentes sociais terem acesso a distintos territórios simultaneamente, por meio de interfaces técnicas, tecnológicas e informacionais, conforme sua capacidade de pagar por esse acesso.

Cabe indicar que o autor não esclarece o conceito de poder, que ele associa a controle/dominação e, por outro lado, ao longo do texto, fica evidente que o autor se inspira em Sack (1986), com a idéia de "quem controla quem em uma determinada área"; e em Santos, M.; Silveira (2001) com a idéia de "espaço banal".

Após a análise das contribuições levantadas sobre o conceito de território, cabe, por fim, explicitar o que se entende por território e, portanto, a definição que doravante será seguida neste livro.

Do exposto até aqui pode-se concluir que como todo conceito, o de território é um daqueles em elaboração, o que constitui tarefa nada fácil de explicar diante do grau de complexidade que envolve o tema. Por enquanto, o que se pretende até aqui é contribuir para iluminar os caminhos a serem trilhados. Nesse sentido, compreende-se a territorialidade como um processo social que envolve um feixe de inter-relações mediadas por acordos formais ou não entre distintos agentes que se interessam por algum tipo de objeto comum a eles localizado numa dada porção do espaço geográfico que se torna território. 



\section{O Recôncavo Baiano pré-Petrobras}





\section{O Recôncavo Baiano pré-Petrobras}

Neste capítulo, busca-se compreender a natureza, o significado e as implicações espaciais das ações desenvolvidas pelos diferentes agentes sociais admitidos neste estudo como relevantes no processo de reprodução do espaço geográfico no Recôncavo Baiano, a saber: os usineiros de açúcar, os fornecedores de cana, os trabalhadores dos canaviais e usinas, os lavradores de fumo e operários das fábricas de fumo, os fazendeiros, e os negociantes e industriais do fumo, o Governo em suas distintas escalas de ação, os banqueiros e grandes comerciantes, o CNP e a partir de 1954 a Petrobras. Esses agentes condicionaram a evolução do Recôncavo Baiano ao longo da década de 1940 e início dos anos 1950, período que antecedeu as ações da companhia de petróleo Petrobras nessa parte do espaço geográfico.

Com essa perspectiva, pretende-se verificar se, durante esse período, com o desenvolvimento das ações de reprodução do espaço geográfico no Recôncavo Baiano e com base nas relações sociais entre os referidos agentes, também foi possível fazer emergir um território específico, determinado pela hegemonia de um dado agente social que, por meio de sua liderança, conduziu o processo de materialização da territorialidade nessa porção do espaço geográfico.

Como já foi destacado tem-se por território uma parte do espaço geográfico que contém objetos de interesse comum a vários agentes sociais e esta unidade espacial é apropriada - não no sentido de posse, mas de reconhecimento da hegemonia de um dado agente - e usada por distintos agentes sociais sob a liderança de um deles, que se tenha tornado hegemônico mediante relações de poder.

Feita a opção da categoria poder pela via arendtiana, considera-se que as ações desenvolvidas pelos agentes sociais que nutrem interesses específicos, expectativas e demandas por um dado território devem necessariamente ser mediadas por relações de negociações, as quais envolvem assimetrias que se manifestam por meio de conflitos de interesses e não igualdade.

As assimetrias tornam-se patentes pelo grau diferente de capacidade de convencimento de que dispõe cada um dos agentes envolvidos na relação, segundo sua importância e natureza, no sentido de defender seus interesses e prover suas demandas, diante do constante questionamento levantado pelos demais agentes envolvidos na relação. Como resultado disso, um dado agente social, que na relação com os outros se move progressivamente, conquistando a anuência de seus pares, segundo uma idéia de consenso, irá, aos poucos, se habilitando a assumir a liderança no consenso e, portanto, exercer a posição de hegemonia no território. 
É com essa compreensão sobre o conceito de território e sobre as categorias poder e hegemonia que se busca investigar as relações entre os diferentes agentes sociais no processo de reprodução do Recôncavo Baiano, a partir da década de 1940 até a chegada da Petrobras, em 1954, quando tiveram início as ações diretas dessa empresa nessa parte do espaço geográfico.

A escolha dos agentes baseou-se na consideração da relevância de cada um deles no processo de reprodução do referido território. A idéia de relevância dos agentes é retirada de Bijker; Pinch (1987), que explicam como cada agente interfere no processo de surgimento e de desenvolvimento dos objetos. A perspectiva sugerida pelos autores na abordagem dos agentes é promissora, pois envolve uma dinâmica de interesses entre os agentes - instituições, organizações e indivíduos - para a compreensão dos processos sociais e das respectivas formas espaciais.

\section{O Recôncavo Baiano}

Toma-se aqui como Recôncavo Baiano uma extensão do espaço geográfico diretamente associado aos aspectos econômicos, sociais e culturais que evoluíram sob as influências da tradição da economia açucareira e de suas respectivas atividades acessórias - produção de alimentos e criação de animais para o abastecimento da população local e a fumicultura, cujo produto era utilizado inicialmente no tráfico negreiro e depois se consolidou como lavoura comercial de alto rendimento nos mercados europeus.

Na divisão espacial da produção brasileira o Recôncavo Baiano era animado diretamente pela cidade do Salvador, com a sua função portuária e administrativa, ligando a Bahia preferencialmente aos mercados nacional e estrangeiro, a partir dos anos 1930, aos mercados da região Sudeste, por meio da aquisição de mercadorias industrializadas.

Segundo os estudos de Costa Pinto (1958), Azevedo, A. (1952) e Santos, M. (1959a), o Recôncavo Baiano na década de 1950 era formado por 22 municípios que se distribuem no entorno da Baía de Todos os Santos e se estende por um raio de cerca de $100 \mathrm{~km}$, a partir da cidade do Salvador (Figura 1).

Mesmo sendo uma área de produção de riquezas em escala comercial, suas vias de circulação interna, nessa época, eram muito precárias, fato que tornava deveras difícil e demorada a circulação de pessoas e mercadorias, principalmente durante os períodos de maior intensidade pluviométrica, entre os meses de março e junho. Como o Recôncavo Baiano é uma área de intensa pluviosidade, em torno de $1.500 \mathrm{~mm}$ anuais, as chuvas tornavam lamacento e escorregadio o leito das poucas estradas de barro que ali existiam. Para se ter uma idéia da precarie- 
Figura 1 - Recôncavo Baiano: localização e divisão municipal - 1950.

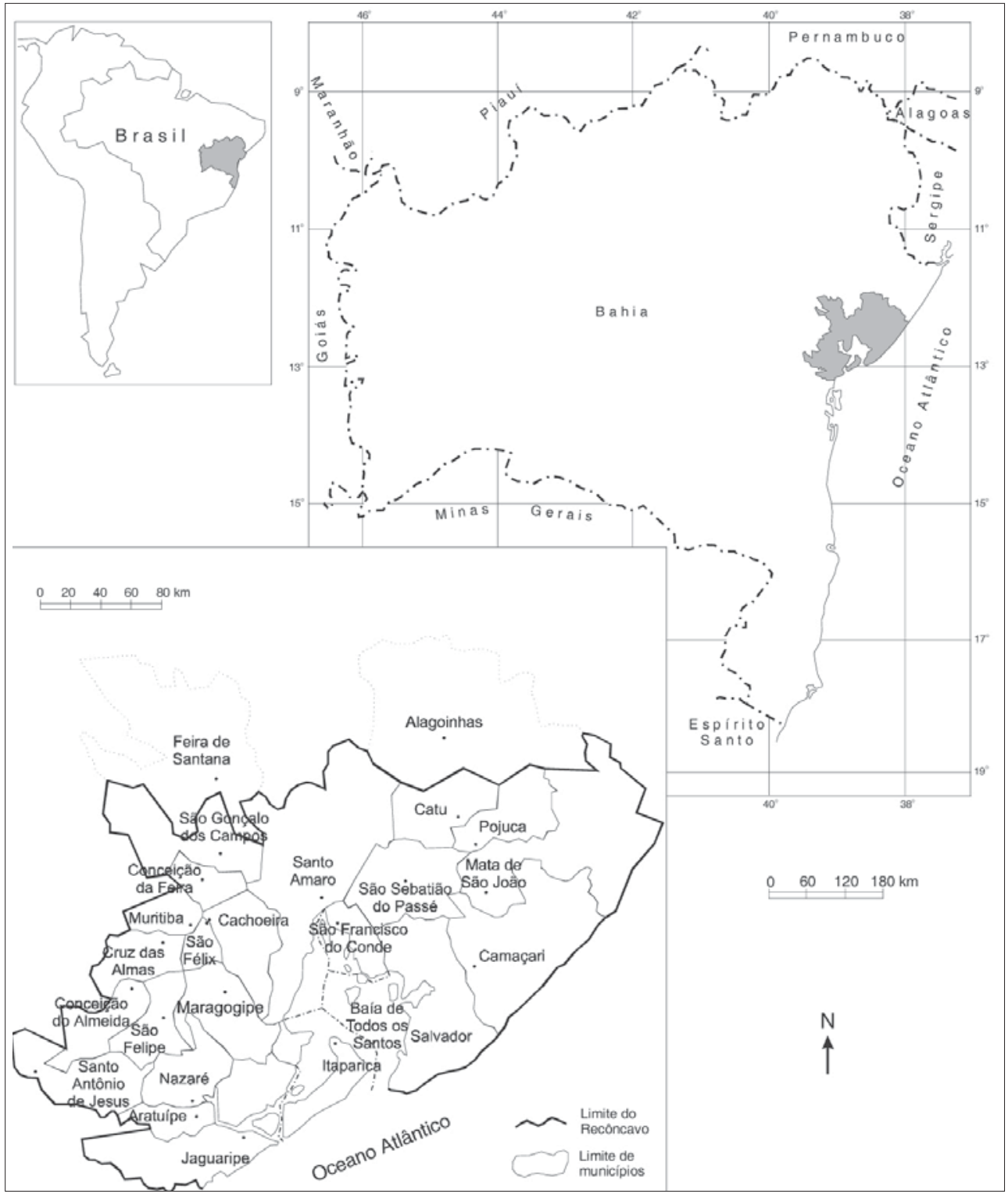

FONTE: elaborado e adaptado por Brito (2004), com base em Bahia (2000).

dade do transporte rodoviário, a antiga estrada das boiadas, a rodovia Salvador/ Feira de Santana, a mais importante estrada de rodagem localizada nessa área na época, foi asfaltada somente em 1959. A estrada das boiadas era o caminho 
por onde se transportava, a pé, o gado procedente do Sertão, destinado aos abatedouros, em Salvador.

A navegação nas águas da Baía de Todos os Santos era, provavelmente, o meio de transporte mais importante. Essa modalidade de transporte era realizada por grandes embarcações e também pelos saveiros, que realizavam a maior parte da navegação entre os pequenos portos no Recôncavo Baiano (inclusive os portos fluviais); por terra, as estradas de ferro e os trens que por elas circulavam ligavam setores do interior baiano às zonas portuárias e à capital, conforme explica Santos, M. (1959a).

Desde o século XVI até por volta de 1950 nas terras do entorno da Baía de Todos os Santos, foi se configurando uma segmentação espacial com base na especialização produtiva, organizada em torno da produção do açúcar, envolvendo canaviais, engenhos, usinas, áreas de matas para extração da madeira para usar como combustível e áreas de cultivo de alimentos e de criação de animais. Os engenhos de açúcar, a partir de 1875 evoluíram para uma posição cada vez menos importante na atividade açucareira; a situação foi se complicando para os senhores de engenho, até que no início do século XX grande parte das terras dos engenhos foi adquirida pelos usineiros de açúcar.

O grande móvel que proporcionava a expansão e/ou a contração da economia açucareira no Recôncavo Baiano era, sem dúvida, a demanda e os respectivos preços animadores do açúcar no comércio exterior, entre os séculos XVIXVIII. Isso fazia com que as lavouras de cana e suas unidades de transformação, os engenhos de açúcar, tivessem, durante esse período, uma vasta disseminação nas terras do massapê (as mais férteis e úmidas) e, inclusive, até em terras de tabuleiros, nas áreas mais secas e de solos menos férteis, localizadas na periferia imediata do Recôncavo Baiano. Tal condição implicava uma ampla extensão do Recôncavo açucareiro, onde quaisquer outras culturas agrícolas e/ou criação de animais tinham somente função acessória.

Desde a primeira grande crise do ciclo econômico da cana-de-açúcar, na segunda metade do século XVII (PRADO JR., 1988), a área de cultivo de cana-deaçúcar passou a diminuir no Recôncavo Baiano, refletindo as sucessivas fases de crise e tentativas de recuperação do mercado do açúcar no exterior.

Ainda na primeira metade do século XIX, a concorrência externa ao açúcar brasileiro não vinha somente dos produtores estabelecidos nas Antilhas, mas também da própria Europa, que passaram a produzir açúcar de beterraba. A Europa, em períodos anteriores, constituía o grande mercado consumidor de açúcar do Brasil.

Como reflexo da Primeira Guerra Mundial, os cinco primeiros anos que se seguiram a ela foram favoráveis à recuperação temporária dos preços para frações importantes do mercado de açúcar brasileiro no exterior, devido à destruição dos campos de cultivo de beterraba e das fábricas de açúcar; mas, por volta de 1923, a 
crise se estabeleceu novamente no comércio internacional do açúcar com a retomada da refinação de açúcar de beterraba na Europa. O mesmo se repetiu após a Segunda Guerra Mundial e, novamente, as dificuldades reapareceram no mercado externo, com repercussões bastante negativas para o setor açucareiro brasileiro conforme explica o Instituto do Açúcar e do Álcool (IAA) em 1972.

As repercussões da crise no mercado do açúcar no exterior contribuíram para manter o processo de decadência da atividade açucareira no Recôncavo Baiano, não constituindo, contudo, um fator determinante, mas resultando no recuo da área antes ocupada com a cultura de cana-de-açúcar, na diminuição do número de usinas e, por conseqüência, em grande escassez de açúcar no mercado regional.

Esse fato se atribui, principalmente, a decisões tomadas pelos financistas e usineiros baianos de agir de maneira estritamente especulativa na atividade açucareira, diante da expectativa de obter taxas de lucros inferiores as que poderiam ser auferidas no financiamento da produção de outros produtos de exportação, como o cacau, por exemplo, que oscilou de U\$ 90,8/t em 1940 para U\$ $595,9 /$ t em 1950, além de outros produtos que apresentaram rendimentos bastante elevados em relação ao açúcar que era comercializado a U\$ 29/t em 1940 e fechou a década a U\$ 139/t, tendo atingido U\$ 192/t em 1947 (Tabela 1).

Tabela 1 - Bahia: preços dos produtos para trocas internacionais (U\$/t) - 1940/1950

\begin{tabular}{|c|c|c|c|c|c|c|c|c|c|c|c|}
\hline \multirow{2}{*}{ Produtos } & \multicolumn{11}{|c|}{ Ano } \\
\hline & 1940 & 1941 & 1942 & 1943 & 1944 & 1945 & 1946 & 1947 & 1948 & 1949 & 1950 \\
\hline Açúcar* & 29 & 20 & 53 & 76 & 83 & 102 & 169 & 192 & 102,3 & 108 & 139 \\
\hline Cacau & 90 & 120 & 153 & 151 & 153 & 138 & 257 & 569 & 795,6 & 388 & 586 \\
\hline Mamona & 51 & 44 & 66 & 67 & 66 & 67 & 92 & 191 & 142,6 & 107 & 114 \\
\hline Borracha & 267 & 301 & 516 & 635 & 901 & 923 & 726 & $\ldots$ & $\ldots$ & $\ldots$ & $\ldots$ \\
\hline Fumo & & & & $\cdots$ & 268 & 447 & 470 & 516 & 542,3 & 520 & 617 \\
\hline Sisal & $\cdots$ & $\ldots$ & $\ldots$ & $\ldots$ & $\ldots$ & $\ldots$ & 291 & 347 & 310,3 & 272 & 292 \\
\hline $\begin{array}{l}\text { Couro/Peles } \\
\text { Manteiga }\end{array}$ & $\ldots$ & $\ldots$ & $\ldots$ & $\ldots$ & $\ldots$ & $\ldots$ & $\ldots$ & $\ldots$ & 573,7 & 795 & 520 \\
\hline de cacau & $\ldots$ & $\ldots$ & $\ldots$ & $\ldots$ & $\ldots$ & $\ldots$ & 522 & 1.292 & 1.833 & 895 & 932 \\
\hline
\end{tabular}

FONTE: Organizada por Cristovão Brito (2004), com base em IBGE (1947, 1949, 1951).

* No período, o estado da Bahia não exportou açúcar para o exterior.

... Dado não disponível.

Deve-se salientar que durante as décadas de 1940 e 1950, os usineiros das mais importantes regiões brasileiras produtoras de açúcar (São Paulo, Rio de Janeiro e Pernambuco) faziam o caminho inverso dos usineiros do Recôncavo Baiano, buscando ampliar o número de usinas e a capacidade de moagem de cana, tanto para a produção de açúcar, quanto para a de álcool carburante nas destilarias (SZMRECSÁNYI, 1979). 
Importa dizer que, no período em análise, os usineiros do estado da Bahia não produziram açúcar em escala suficiente para a exportação e que, das demais mercadorias relacionadas na Tabela 1, apenas o fumo era produzido no Recôncavo Baiano, porém sem exclusividade.

Com isso, enquanto no período colonial os canaviais e engenhos se distribuíam ao longo da orla da Baía de Todos os Santos e chegavam a adentrar pelas bordas mais secas do Recôncavo Baiano, por volta de 1940/1950 a lavoura canavieira tinha sua área core restrita aos municípios de Santo Amaro, São Sebastião do Passé e São Francisco do Conde (COSTA PINTO, 1958). No entanto, no mesmo período, em suas adjacências existiam outros municípios que cultivavam a cana-de-açúcar, mas em menor proporção, conforme se pode verificar na Figura 2.

Figura 2 - Recôncavo Baiano: distribuição do cultivo exclusivo de cana-de-açúcar por município, nos estabelecimentos declarados - 1950.

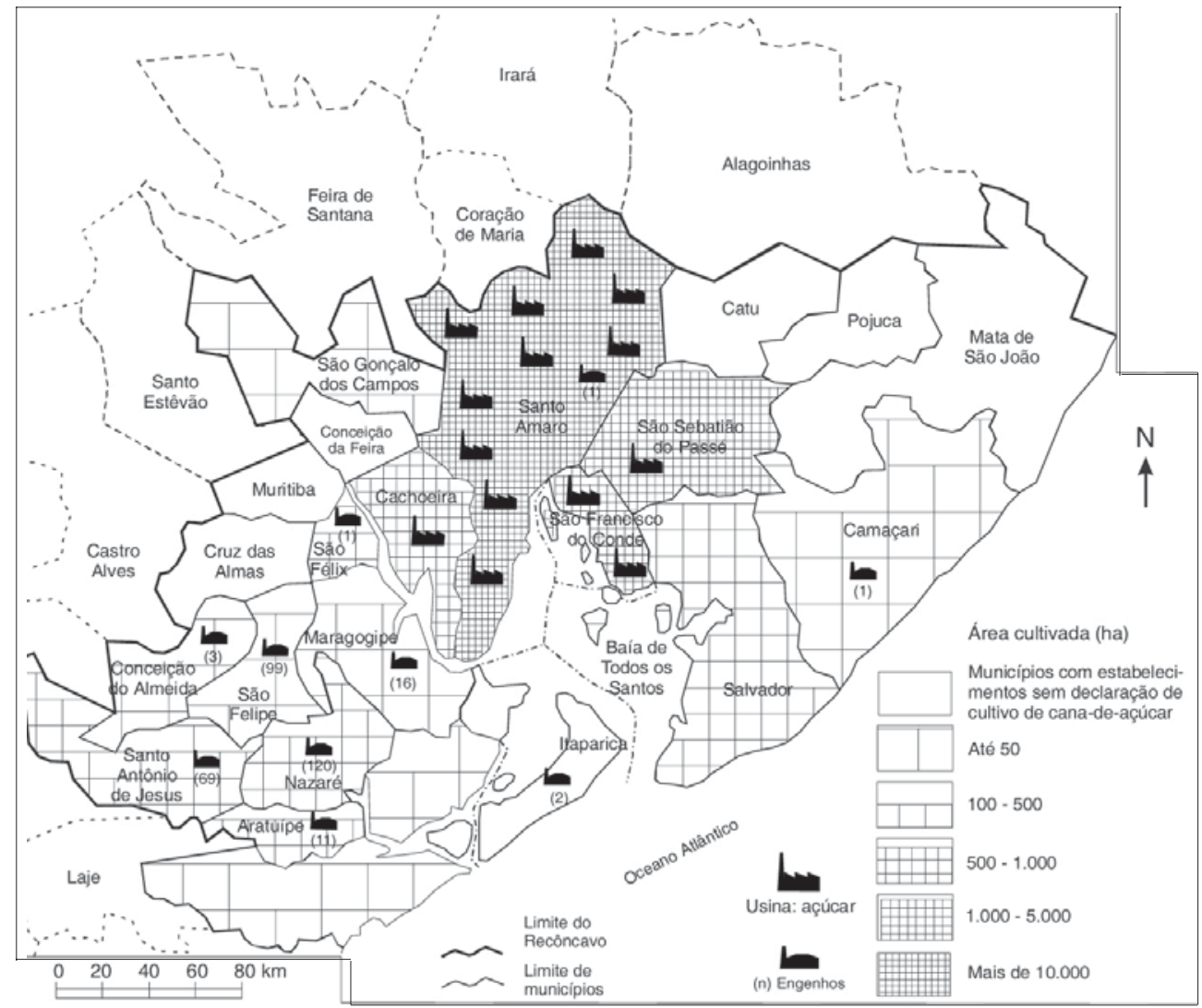

FONTE: Organizada por Brito (2004), com base em IBGE (1955), S. Amaro ... (1946), Cunha (1995) e expresidente do sindicato das indústrias do Açúcar e do Álcool (2002)*.

* Entrevista concedida à Cristóvão Brito. 
Embora o Instituto Brasileiro de Geografia e Estatística (IBGE) não tenha publicado os dados referentes à área ocupada com cana-de-açúcar nos estabelecimentos agrícolas para o recenseamento de 1940, nos três municípios anteriormente referidos foram colhidas $73,3 \%$ de toda a cana-de-açúcar nos estabelecimentos com declaração na safra de 1939/1940, contra 90\% na safra de 1949/ 1950, o que reitera a idéia de uma pequena recuperação após a guerra.

No Recôncavo Baiano, os 323 engenhos que aparecem na periferia da área core da cana-de-açúcar, em 1950, não eram significativos em termos da produção açucareira, pois se trata tão-somente de pequenos engenhos operados pelos próprios membros da família, que utilizavam a tração animal para o processamento da cana em nível de auto-suficiência da própria família e para a produção de pequeno excedente 1 . Esses engenhos, portanto, estavam muito distante de qualquer semelhança com a "[...] idéia de verdadeiro senhorio, regido pelos códigos de nobreza territorial, com seu proprietário à frente da produção realizada à custa de trabalho de numerosos escravos" (ARAUJO, T., 2002, p. 48).

A capacidade de transformação da matéria-prima por essas engenhocas era, como tudo indica, bastante limitada, estando muito aquém dos antigos engenhos centrais que empregavam máquinas a vapor e processos de produção complexos; e mais aquém ainda das usinas, que operavam com maior escala de produção e utilizavam processos mais complexos com o uso de turbinas a vapor e câmaras de vácuo.

Essas engenhocas produziam aguardente, rapadura e também açúcar mascavo, mercadorias comercializadas nas feiras livres locais, daí a ocorrência de grande quantidade de engenhos localizados junto aos canaviais e que se distribuíam fora da área especializada na produção de açúcar de usina.

$\mathrm{Na}$ área especificamente açucareira do Recôncavo Baiano localizavam-se as 14 usinas em fins da década de 1940, nos seguintes municípios: Santo Amaro, com 10 usinas e uma destilaria de álcool para os quais dispunha de 13.189 ha cultivados exclusivamente com cana-de-açúcar (470.870 t de cana); São Sebastião do Passé, com uma usina e 4.829 ha (138.000 t de cana); São Francisco do Conde, com duas usinas e 2.411 ha (93.336 t de cana); e por fim, Cachoeira, com uma usina e 837 ha (44.899 t de cana).

\footnotetext{
1 Segundo dados do Anuário Estatístico do Brasil (AEB), no Recôncavo, entre 1940 e 1942 havia dois engenhos turbinadores e a partir de 1943 diminuiu para um. Esses engenhos, diferentemente dos demais, já dispunham de turbina a vapor, maior quantidade de força de trabalho ocupada na fabricação de açúcar e tinham capacidade de processamento de cana e produção de açúcar bem maior; provavelmente, eles se localizavam no município de Santo Amaro ou em municípios adjacentes, próximos de toda a infra-estrutura da indústria do açúcar na época.
} 
Seguindo a tradição dos antigos senhores de engenhos, os usineiros empreendiam uma ação essencialmente arbitrária sobre os fornecedores de cana e também sobre seus funcionários (ARAÚJO, T., 2002; HUTCHINSON, 1975; LOPES, 1978). ${ }^{2}$ Diante disso, cumpre destacar que a permanência dos pequenos engenhos que subsistiam na periferia da zona das usinas era possível graças à grande distância que separava os primeiros dos últimos e as dificuldades de transporte existentes.

A existência de grandes distâncias a vencer e a precariedade do sistema de transporte no Recôncavo Baiano, não são suficiente para explicar a decadência da atividade açucareira e a concentração de usinas de açúcar restritas a uma pequena área; pesam bastante as ações de natureza especulativa determinadas pela condição de a atividade ter se desenvolvido usufruindo das benesses do Estado e pelo lucro fácil a que estavam acostumados os grandes comerciantes e financistas que controlavam a atividade açucareira na Bahia.

\section{A formação do capital dos usineiros}

A atividade açucareira no Recôncavo Baiano na era das usinas esteve cada vez mais determinada pelos interesses de origem urbana, vinculados, principalmente, ao capital mercantil e bancário.

Esse fato revela as razões pelas quais a produção açucareira no Recôncavo Baiano se manteve ao longo de quase todo o século XX no nível de "fogo quase morto", entre o colapso final e a possibilidade de, em algum momento promissor, poder se refazer ou aproveitar-se de conjunturas políticas e comerciais favoráveis. Isso conduz a uma explicação possível do estágio de isolamento relativo e de pobreza, comuns à vida social do Recôncavo Baiano nesse período.

Os grandes comerciantes e banqueiros sediados na cidade do Salvador, com negócios em torno das funções portuárias e comerciais, que tradicionalmente financiavam as atividades agromercantis por volta da década de 1930, passaram também a adquirir a propriedade e/ou a participação nessas atividades.

A esse respeito, digno de destaque, foi o empreendedorismo desenvolvido pela firma S/A Magalhães Comércio e Indústria, a partir de 1932.

Conforme relato de Simões (1993) e Vida... (1954), o fundador da Casa Magalhães \& Cia. nasceu em 1871, na província D'Ouro (Portugal), chegando à Bahia aos 13 anos de idade e sem recursos. Aos 20 anos, abriu um negócio por

\footnotetext{
${ }^{2}$ Apesar de ser uma obra literária de ficção, baseada em fatos da realidade, o romance Usina, de José Lins do Rego (1973), oferece uma excelente medida do arbítrio praticado pelos usineiros, além de descrever toda uma cultura social e de produção desenvolvida em torno de uma usina de açúcar.
} 
conta própria e, dois anos depois, já havia organizado, com um sócio, uma firma com capital de Rs $30.000 \$ 000$ (trinta contos de réis). Em 1932, quando transformou a firma numa S/A, seu capital já era de Cr\$21.350.000,00, aumentando a cada ano. Raymundo Pereira de Magalhães faleceu em 1932. Sua firma encerrou suas atividades em 1954, conforme sugere Simões (1993), mas, o grupo econômico permaneceu através do Banco da Bahia, do qual era um dos maiores acionistas.

Desde a sua fundação pelo comerciante português Raymundo Pereira de Magalhães, em 1891 até a década de 1950, a Casa Magalhães \& Cia., como era amplamente conhecida, conseguiu estruturar um verdadeiro império comercial na Bahia, com negócios espalhados nos estados de São Paulo, Pernambuco, Alagoas e no antigo Distrito Federal, com a matriz na cidade do Salvador. Os negócios da firma envolviam desde o comércio (importação/exportação) grossista e varejista de mercadorias (secos e molhados), intermediações financeiras, inclusive com grandes firmas estrangeiras, até representação comercial de firmas internacionais, a exemplo da Shell. O grupo econômico que emergiu ao redor da Casa Magalhães \& Cia. também era proprietário de diversas fábricas, fazendas, minas, embarcações para o transporte de cabotagem, além de ser grande acionista do Banco da Bahia, conforme relatam Nascimento (1997), Simões (1993), Vida... (1954), Guimarães (1982) e Gnaccarini (1989).

A firma Magalhães \& Cia. entrou logo cedo na atividade açucareira, no Recôncavo Baiano, durante a Primeira Guerra Mundial, através da intermediação de capitais entre as usinas e as firmas estrangeiras para aquisição de máquinas utilizadas no melhoramento da produção de açúcar. Todavia, como era patente o descompasso entre o fornecimento de cana pelos fornecedores, no que se refere à qualidade e à quantidade demandadas pelas usinas e também em virtude da instabilidade dos preços do açúcar no mercado externo, bem como da dificuldade da exportação do açúcar brasileiro, em especial o baiano, os proprietários das usinas nunca conseguiam saldar suas dívidas que se avolumavam junto ao grande credor.

Com isso, paulatinamente, as usinas passavam às mãos da firma Magalhães \& Cia. que, em 1930, já era proprietária das quatro maiores usinas do Recôncavo Baiano: Aliança, São Carlos, São Bento, Terra Nova; na década de 1940, adquiria mais uma, a Santa Elisa (NASCIMENTO, 1997; CUNHA, 1995).

Com a usina Cinco Rios, de propriedade do banqueiro Clemente Mariani, controlador do Banco da Bahia, que também era um político de grande influência, em nível nacional, além de ser um dos mais qualificados diretores da firma S/ A Magalhães, somam-se seis as usinas sob o controle da Casa Magalhães \& Cia., considerando que essa firma, em 1938, ajudou financeiramente Clemente Mariani a adquiri-la, como declara o próprio Mariani: 
[...] menos de um ano depois, [1937], a necessidade de salvar o patrimônio de uma cliente levava-me a assumir a responsabilidade de uma usina de açúcar praticamente em estado de falência.

Para fazê-lo era necessário crédito. Um constituinte para quem trabalhava há 18 anos e cuja amizade até hoje só tem feito fortalecer-se, teve confiança no seu advogado. Os dois mil contos que então me emprestou valeriam hoje cerca de 25 milhões. Tive a felicidade de poder pagá-los em cinco anos, caso virgem na indústria açucareira baiana. Encarregaram-me, então, de reorganizar o Banco da Bahia, de quem eram os maiores acionistas [...] (MARIANI, 1977, p. 119).

Sobre como a Casa Magalhães \& Cia. entrou no fabuloso negócio de aquisição de usinas de açúcar no Recôncavo Baiano, Nascimento explica todo o processo:

\begin{abstract}
Em 1908, a Aliança, através de sua Diretoria, deliberou construir um ramal de estrada de ferro pelas terras dos engenhos Jacuípe, Brotas, Barra e Nazaré. Chegaram, porém, à conclusão de que antes seria necessária uma transformação no maquinário da usina que não tinha sido montado convenientemente, contratando a firma Orenstein e Kappel este trabalho. A Assembléia de 1913 propõe a compra de equipamentos para o aumento da produção, que foi acertada com a firma francesa Henry Mariolli. Devido à guerra de 1914, a firma de comércio grossista Magalhães e Cia. tornou-se a intermediária nos negócios com a Mariolli. Com a guerra de 1914, as usinas foram se endividando e várias sociedades para a produção do açúcar foram dissolvidas. No lugar delas surgiu uma subsidiária de Magalhães e Cia., a Companhia Lavoura e Indústria Reunidas S/A. Nessa oportunidade a Casa Magalhães passa a monopolizar o comércio do açúcar na Bahia e a controlar sua produção (NASCIMENTO, 1997, p. 28).
\end{abstract}

Perruci (1978), citando depoimentos do Cônsul da França na Bahia, em 1913, apresenta mais elementos sobre o processo de incorporação das usinas de açúcar na Bahia pelo capital comercial e bancário no início do século XX. É bem provável, como tudo indica, que a firma de banqueiros portugueses, que apoiava financeiramente grande parte dos usineiros na Bahia, citada pelo depoente, tenha sido o mesmo grupo da firma Magalhães \& Cia., pois o seu proprietário era de origem portuguesa e também grande acionista do Banco da Bahia e conseguiu levantar seu império comercial em um período de tempo relativamente curto, cerca de 20 anos, para quem tinha poucos recursos no início.

O Sindicato Açucareiro da Bahia, que compreende 12 usinas das 21 existentes, foi fundado por uma firma de banqueiros-exportadores portugueses que construíram rapidamente uma fortuna colossal, obrigando os diretores das empresas ajudadas financeiramente por eles a Ihes pagar uma taxa de 10\%, depois a utilizar o Sindicato como intermediário para as vendas do açúcar, pagando $6 \%$ de comissão, para fornecimento de material, compra de sacos de algodão etc; [...] (PERRUCI, 1978, p. 126). 
A ajuda financeira à disposição dos usineiros não se limitava somente a Casa Magalhães \& Cia., já que outros empresários de destaque da capital também se apresentavam na ocasião para compor as sociedades. Junto com eles, as casas bancárias exerciam papel considerável no financiamento da atividade açucareira baiana, apesar de o açúcar não ter sido um produto de grande interesse dos financistas para o comércio exterior, no período de 1940 a 1950.

Como mencionado anteriormente, no fim desse período, havia 14 usinas no Recôncavo Baiano, sendo que seis delas estavam vinculadas diretamente à firma S/A Magalhães, através de sua subsidiária Lavoura e Indústria Reunidas (LIR); duas outras - Paranaguá e Itapetingui - pertenciam a dois grupos distintos de empresários e comerciantes importantes; as demais, seis, provavelmente se supriam de capital para custeio de suas despesas principalmente com a própria LIR e com casas bancárias; o mesmo se estende aos fornecedores de cana. ${ }^{3}$

\section{Os agentes sociais e suas interrelações: em busca da possibilidade de existência de um território dos usineiros de açúcar nos anos 1940}

$\mathrm{Na}$ Bahia, as categorias usineiros e fornecedores surgiram no fim do século $\mathrm{XIX}$, mais precisamente a partir do Decreto Legislativo $\mathrm{n}^{\circ} 2.687$, de 6 de novembro de 1875. Essa lei, de âmbito nacional, específica para o setor canavieiro/ açucareiro, favorecia, com isenção de taxas de importação de equipamentos e garantia de remuneração de juros de $7 \%$ ao ano sobre o capital, as sociedades que passassem a investir recursos na fundação de engenhos centrais, contanto que não utilizassem força de trabalho escravo (ARAúJO, 2002).

Dessa maneira, o Governo imperial esperava promover o "[...] desenvolvimento da economia açucareira envolvida em uma série de dificuldades, que se supunha debelar com a implantação dos engenhos centrais" (ARAÚJO, 2002, p. 30). Com o advento dos engenhos centrais, estimava-se que haveria melhores condições de competição do açúcar brasileiro no exterior a partir da adoção de processos complexos de industrialização do açúcar com maior eficiência na fabricação e, por outro lado, os fornecedores de cana poderiam dedicar-se aos melhoramentos que, em princípio, iriam ocorrer a partir da exclusividade de sua função. A emergência das fábricas centrais implicava a substituição dos antigos engenhos e de seus métodos arcaicos de produzir açúcar.

3 Outro grupo de comerciantes, porém de menor importância, foi a família Falcão, de Feira de Santana, que adquiriu a usina Itapetingui, em Santo Amaro. 
Como os engenhos centrais foram substituindo os engenhos tradicionais, os senhores de engenho menos aquinhoados, proprietários desses últimos, teriam que utilizar suas terras para o cumprimento da função de fornecimento de cana para atender às necessidades dos primeiros, isso fazia parte, inclusive, da citada legislação. Dessa maneira, efetivava-se uma divisão do trabalho entre a fábrica de açúcar e as fazendas de cana.

Contudo, como os investimentos nas fábricas centrais de açúcar eram vultosos, somente um seleto grupo de senhores de engenho mais ricos, dispondo de importante prestígio social e político - boa parte tinha título de nobreza, os Barões -, aliado a financistas, a grandes comerciantes e a traficantes de escravos, poderia arcar com os altos custos, ficando de fora um grande grupo de senhores de engenho, sem recursos, endividados e sem prestígio, possuidores apenas de terras esgotadas e vivendo da tradição (ARAÚJO, 2002).

A iniciativa dos engenhos centrais malogrou. Não durou muito tempo devido principalmente aos conflitos surgidos entre os fornecedores de cana e os proprietários das fábricas centrais. Como essas últimas aumentavam cada vez mais sua capacidade de moagem de cana e de fabricação de açúcar, e os fornecedores não correspondiam às demandas de cana, os proprietários dos engenhos centrais buscavam, de diversas maneiras, adquirir terras para cultivar a própria cana. Esse fato implicava diretamente o aumento do capital da firma e, portanto, a ampliação da sociedade, com a respectiva admissão de novos sócios.

Esse processo resultava, não raro, na constituição das usinas e no surgimento dos usineiros, os quais agiam de maneira despótica em relação a todos os demais agentes que se colocavam na trajetória de expansão do empreendimento.

\section{As relações sociais e de produção entre os agentes e suas implicações espaciais no Recôncavo Canavieiro}

As usinas de açúcar tiveram expressivo desenvolvimento no início do século XX no Recôncavo Baiano, substituindo os engenhos centrais e aniquilando grande parte dos fornecedores de cana, com a respectiva incorporação de suas propriedades.

É verdade que algumas usinas surgiram sem a necessidade de passar pela fase de engenho central, que, juridicamente, tinha de obedecer ao critério da separação entre fabricação de açúcar e/ou álcool e o cultivo da cana. Prova disso foi a constituição de uma das maiores usinas de açúcar, Aliança, em 1892, no município de Santo Amaro. Essa usina surgiu da reunião de três engenhos banguês, de uma mesma família e tinha uma capacidade inicial de moagem de cana diária de 
250 toneladas. ${ }^{4}$ Atualmente, a usina Aliança é a única em funcionamento no Recôncavo Baiano.

Contudo, na linha de sucessão dos engenhos centrais por usinas, uma das primeiras e mais importantes a se constituir foi a Companhia Usina Bom Jardim (Maracangalha), fundada em 1912, no município de São Sebastião do Passé, com um capital social de 5.000:000\$000 (cinco mil contos de réis). O proprietário desse engenho central era o Senhor Álvaro Martins Catharino, membro de uma importante e influente família baiana.

O engenho central Maracangalha foi fundado em 1889 pelo Barão Moniz de Aragão, com um capital inicial de 400:000\$000 (quatrocentos contos de réis), que foi aumentado um ano depois para 750:000\$000 (setecentos e cinqüenta contos de réis) garantido pelos Governos da Bahia e federal, segundo explica Araújo (2002). Como esse, e nas mesmas condições houve vários outros casos de transformação de engenhos centrais em usinas no Recôncavo Baiano.

O mesmo processo de que se originaram os usineiros de açúcar fez emergir também os fornecedores de cana, como categoria social instituída. Porém, como destaca Araújo (2002), os pequenos proprietários e lavradores viviam numa estrutura social patriarcal e sob o mando inconteste dos senhores de engenho. Dessa maneira, eles não tinham outra alternativa senão entregar o resultado de suas lavouras aos senhores de engenho, que nem sempre agiam de boa fé, pois, muitas vezes, deixavam perder a cana e/ou a moíam sem o devido pagamento aos verdadeiros donos. Assim, em virtude de não disporem de moendas para processar a própria cana, aos fazendeiros menos importantes era imposta a condição de fornecedores involuntários, mesmo antes da fundação dos engenhos centrais.

Já sob o jugo dos usineiros, os fornecedores de cana, que em grande parte descendem de famílias de antigos senhores de engenhos, endividados e sem prestígio, possuidores apenas de terras esgotadas, exploravam suas fazendas como os seus antecessores faziam há séculos. Segundo Silva, J. (1973), em depoimentos colhidos entre seus informantes, fica patente que vem de longo tempo a nãoutilização de técnicas agrícolas convenientes e já conhecidas: adubação química e/ou orgânica, utilização de plantas selecionadas, combate a pragas, irrigação, curvas de nível, mecanização etc., nos tratos culturais da cana, apesar de os Governos estadual e federal disponibilizarem os instrumentos para tal - incentivos financeiros e técnicos. Sobre isso evidencia Silva, J. (1973, p. 48):

Poucas áreas canavieiras do Brasil tiveram condições tão privilegiadas como a do Recôncavo. Ai se instalou um tripé científico da mais alta importância e que nunca se integrou ao sistema: a estação experimental de Jacuípe, [...], a escola Agronômica de Cruz das Almas e o Instituto de Pesquisas Agro-Pecuárias do

\footnotetext{
${ }^{4} \mathrm{O}$ bangüêe é um engenho de açúcar, de sistema antigo, movido a tração animal.
} 
Leste, cujos trabalhos específicos de experimentação e pesquisas científicas voltados para cana de açúcar são insignificantes.

Convém ressaltar que a baixa utilização de recursos técnicos é um fato comum ao sistema canavieiro do Recôncavo Baiano - nas fazendas, tanto das usinas, como dos fornecedores. Contudo, vale destacar que os usineiros dispõem de maiores recursos que os fornecedores e detêm grande quantidade de terras anexas às usinas para o próprio fornecimento de cana.

Em entrevista realizada com funcionários aposentados de uma usina que funcionou até a década de 1980 no Recôncavo Baiano, foi revelado que a mesma chegou a possuir mais de 20 fazendas, plantadas exclusivamente com cana, o que confirma a forte concentração da propriedade da terra em mãos dos usineiros.

Com o advento das usinas, a condição dos fornecedores na estrutura da produção açucareira tendia a ficar cada vez mais precária, a partir das pressões desferidas constantemente pelos usineiros com o fito de ampliar a área de suas unidades fornecedoras de cana. As estratégias utilizadas pelos usineiros para adquirir as propriedades dos fornecedores eram bastante variadas e muito eficazes, Silva, J. (1973), Hutchinson (1975) e o jornal O Momento as esclarecem. ${ }^{5}$

A reportagem do jornal $O$ Momento sintetiza o mecanismo de expropriação das terras dos fornecedores de cana por parte dos usineiros no município de Santo Amaro, ao descrever o processo pelo qual um grupo de usinas pertencente à firma S/A Magalhães, monopolista da fabricação e distribuição de açúcar na Bahia:

\begin{abstract}
Chegamos a contar seis engenhos comprados pelo monopólio. Estes não são engenhos mas apenas fazendas de cana de açúcar (sic), nas quais havia, em geral, antes, um engenho modesto. Estas fazendas produziam a cana e vendiam, mesmo antes das colheitas, às usinas. É evidente, porém, que o chamado "engenho" só podia vender a cana às usinas mais próximas, muitas vezes sem escolher entre dois compradores, dada a distância de outras usinas que não a compradora e a dificuldade do transporte da cana. O resultado disso era que a usina impunha o preço para comprar a cana. Com prejuízos cada vez mais crescentes e evidentes, os proprietários dessas fazendas viam-se na contingência de vendê-las, sob pena de sofrerem maiores prejuízos - e a compra era feita em regra por um preço muito menor do que o valor real (EM SANTO..., 1946, p. 2).
\end{abstract}

A contenda entre usineiros e fornecedores de cana durante os anos 1950 também é apresentada por Hutchinson (1975, p. 128) da seguinte maneira:

\footnotetext{
${ }^{5} \mathrm{O}$ jornal $\mathrm{O}$ Momento era o veículo de comunicação do Partido Comunista Brasileiro.
} 
Não somente os membros da numerosa família Conde, mas também outros fornecedores de cana, ressentiram-se com os métodos despóticos e bruscos dos novos gerentes. Querendo se desligar completamente do passado, estes introduziram várias atitudes novas em suas relações com os fornecedores de cana. Antes, os fornecedores particulares compravam açúcar por saca, adquiriam seus mantimentos na loja da empresa, e consertavam suas máquinas nas oficinas da empresa, pagando por tais serviços no fim da estação das colheitas. [...] Agora, entretanto, a Usina São Pedro quer receber o pagamento no momento da prestação do serviço a cada fornecedor. Mais: a usina tem diminuído paulatinamente o número de serviço que oferece aos fornecedores.

No começo os novos gerentes cobravam um desconto automático sobre a tonelagem de cana fornecida por cada fazenda.

Dessa maneira, as relações entre os usineiros e os fornecedores se deterioravam a cada dia. Essas várias modalidades de coações desferidas pelos usineiros contra os fornecedores resultavam no que o autor $(1975$, p. 128) sublinha: "Ponto central de agrupamento social dos fazendeiros da região há alguns anos atrás, a usina é agora um lugar a ser evitado". Com essas medidas, o interesse maior dos usineiros era de aniquilar os fornecedores e adquirir suas terras a preços vis, como destaca Hutchinson (1975, p. 129):

\begin{abstract}
A situação tem todas possibilidades para levar a uma tradicional captura de terras. A usina precisa de terras para produzir mais cana para poder operar em plena capacidade. Ninguém quer vender para a usina, nem fornecer tanta cana quanto poderia em outras condições. Mas os fazendeiros são dependentes da usina, economicamente e por seus serviços. Portanto, é fácil para a usina dificultar as coisas para eles e, mesmo, gradativamente, levá-los à falência, pois eles operam com crédito e têm pouca margem para suportar até mesmo uma quebra de colheita. Tal situação dá à usina oportunidade de adquirir as terras que ela muito precisa a baixo preço.
\end{abstract}

Silva, J. (1973), conclui que os mecanismos de usurpação da propriedade dos fornecedores de cana pelos usineiros no Recôncavo Baiano também valem para os usineiros menores. Com relação aos últimos, o autor (1973, p. 61) escreve: "Esse processo utilizado não significava necessariamente o uso da terra nem o uso das unidades industriais, no caso de fazendas, engenho, ou pequenas usinas, mas a eliminação de concorrentes e uma concentração de poder." E em seguida, Silva, J., $(1973$, p. 62) denuncia a confissão pública de um usineiro, num Simpósio sobre a lavoura canavieira, em 1973, ao afirmar - "[...] nós aviltamos os fornecedores".

Nessa mesma linha de abordagem, um outro tipo de coação de usineiro contra usineiro também pôde ser identificado pelo diário O Momento, expresso da seguinte maneira:

O monopólio Magalhães não manda apenas em suas usinas, mas também indiretamente, na generalidade das outras - e essa autoridade sobre os usineiros 
menores é a arma de que dispõe o explorador do povo para explorar, também, as usinas menores.

A usina Capanema é pequena e pertence ao Sr. José B. Marques. Outra vítima da constante ameaça de Magalhães. Durante as colheitas, o monopólio diminui os preços assustadoramente, embora essa diminuição não seja sentida pelo povo nem pela Superintendência do Abastecimento. O monopólio é rico e pode ficar sem vender açúcar durante todo um ano, mas as outras usinas são obrigadas, por compromissos, a vender o açúcar pelos preços impostos pelo monopólio. Quando se consuma essa venda, ao próprio Magalhães, o açúcar sobe de preço, outra vez, assustadoramente. Mas antes disso já ficou atrás o enorme prejuízo das outras usinas. Ao que soubemos a Usina Capanema está devendo 1.000.000 de cruzeiros [U\$ 51.519,8] ao monopólio e não plantou, este ano, seus canaviais (S. AMARO, ..., 1946, p. 2, 6).

Como resultado disso, operou-se um processo generalizado de concentração da propriedade da terra, sobretudo nas áreas de forte atividade canavieira, em que se destacam os municípios de São Sebastião do Passé, Santo Amaro, Cachoeira e São Francisco do Conde entre aqueles de maior concentração de terra, cuja área ocupada com grandes propriedades atinge 75\%,75\%, 87\% e 94\%, respectivamente, da área total dos municípios (Gráfico 1).

Gráfico 1 - Recôncavo Baiano: área ocupada e tamanho dos estabelecimentos agrícolas, por município - 1950

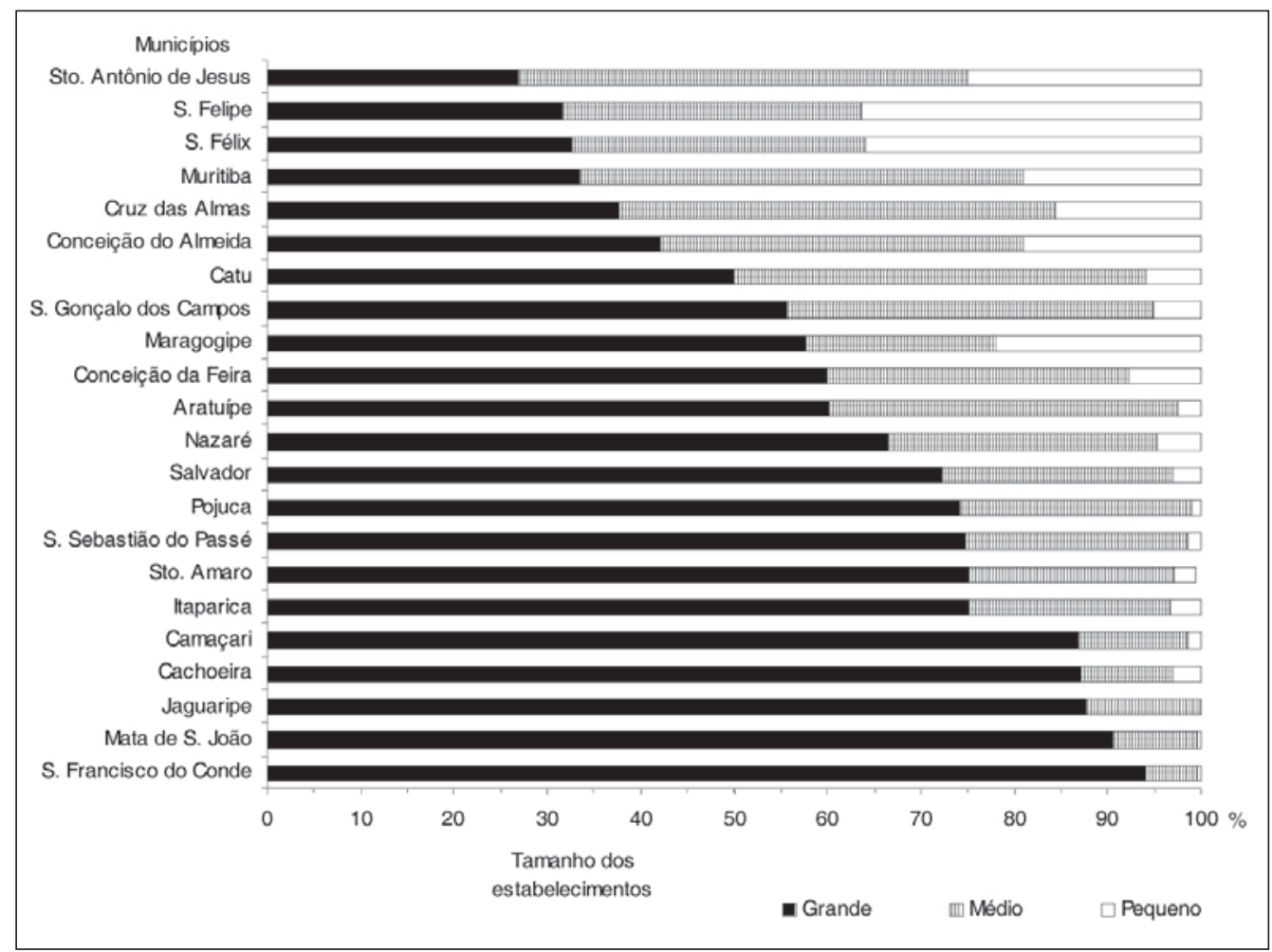

FONTE: Organizado por Brito (2004), com base em IBGE (1950). 
Os demais municípios que também registram forte concentração da propriedade da terra no Recôncavo Baiano têm sua explicação ligada ao processo histórico de formação da propriedade fundiária no Brasil. Alguns desses municípios, os da parte Norte, historicamente estavam voltados para a criação de animais desde o século XVIII e os demais, grande parte deles estava mesmo ligada aos engenhos de açúcar, a exemplo de Mata de São João e Pojuca, nos quais, no início do século XX existia um engenho central em cada município.

De todos os exemplos nos quais ficam patentes as ações de dominação de um agente social, usineiro, sobre o outro, fornecedores e usineiros menores, o que fica claro é o fato de o agente mais forte vislumbrar a possibilidade de beneficiar-se da condição de monopólio no mercado de açúcar para pressionar os órgãos oficiais de regulação de preços no sentido de obter concessões de aumentos, e também granjear recursos do Governo alegando problemas econômicos no setor.

O domínio do monopólio do açúcar pela firma S/A Magalhães permitia-lhe a utilização recorrente do recurso de retirar grande parte do açúcar do mercado para forçar a elevação do preço do mesmo, conforme denuncia o jornal O Momento:

É sabido que a Comissão Estadual de Preços, baseando-se nas últimas safras,
deliberou descer o preço do saco do açúcar que é de $(\$) 161,00[\cup \$ 8,6]$ para $(\$)$
$148,00[\cup \$ 7,9]$ sendo que, ainda por este preço ficará boa margem de lucros
aos cavalheiros do terrível monopólio. [...] É visando torpedear esse tabelamento
que Magalhães cria, agora, uma absurda falta de açúcar, pondo em situação
aflitiva todo o povo baiano e criando dificuldades inclusive, ao próprio governo.
Em conseqüência da manobra altista iniciada pela S/A Magalhães, vem faltando
açúcar nos armazéns e demais casas varejistas (A FALTA..., 1947, p. 1).

Dado que o grupo empresarial S/A Magalhães era o maior acionista do Banco da Bahia, além de possuir vários outros empreendimentos de semelhante importância, e contando ainda com um dos mais destacados e influentes líderes políticos baianos, Clemente Mariani, à frente dos negócios, a subsidiária LIR exercia grande influência no Governo estadual; no Governo federal sua influência também se fazia presente, mas em menor grau. Nesse sentido, Cunha (1995), evidencia a intenção da LIR junto ao Governo da Bahia ao destacar que:

Sua influência no Governo baiano, assim como o peso dos usineiros na política dos estados produtores, pode ser observada pelo memorial enviado ao Governo federal, assinado por 8 governadores, pedindo o aumento do preço do açúcar. O governador baiano, Régis Pacheco, foi um dos signatários do documento, que afirma ser o preço tabelado do açúcar inferior aos custos de produção em 1951. Este Memorial, entretanto foi apresentado meses depois da casa Magalhães ter divulgado o balanço da LIR apontando um lucro líquido superior a $\mathrm{Cr} \$ 7,8 \mathrm{mi}-$ Ihões [U\$ 416.667] em suas usinas (CUNHA, 1995, p. 52). 
Por outro lado, as justificativas recorrentemente utilizadas pelos usineiros para aquisição de novas fazendas, com o objetivo de ampliar a produção de açúcar em suas usinas não têm outro sentido senão a eliminação dos fornecedores externos e, por extensão, outras usinas que, endividadas, sem dispor de extensos canaviais e de fornecedores particulares ficavam na iminência de encerrar suas atividades.

Mesmo com o gigantismo das grandes usinas do Recôncavo Baiano, o nível de produção de açúcar pelas usinas, ao longo dos anos 1940, sempre foi mantido baixo e de qualidade questionável. Apesar da grande concentração da propriedade da terra pelas grandes usinas, persistia a pequena quantidade de cana moída e sua oferta irregular que, associada ao baixo nível técnico utilizado, implicavam uma produção limitada de açúcar que pode ser avaliado pelo Gráfico 2.

Nesse gráfico, o registro de uma forte queda na quantidade de cana moída, em 1942, refere-se à ocorrência de uma grande seca, fato que deve ter comprometido um melhor desempenho daquela safra.

Comentando sobre a qualidade e o preço elevado do açúcar, observa a reportagem de $O$ Momento (A FALTA..., 1947, p. 1), "Sobre isto um técnico e industrial paulista, há poucos dias falando a um diário local, teve a oportunidade de dizer que o bahiano, além de pagar um alto preço, consome um açúcar de péssima qualidade."

Gráfico 2 - Recôncavo Baiano: evolução da quantidade de cana moída e da produção de açúcar nas usinas - 1940/1949

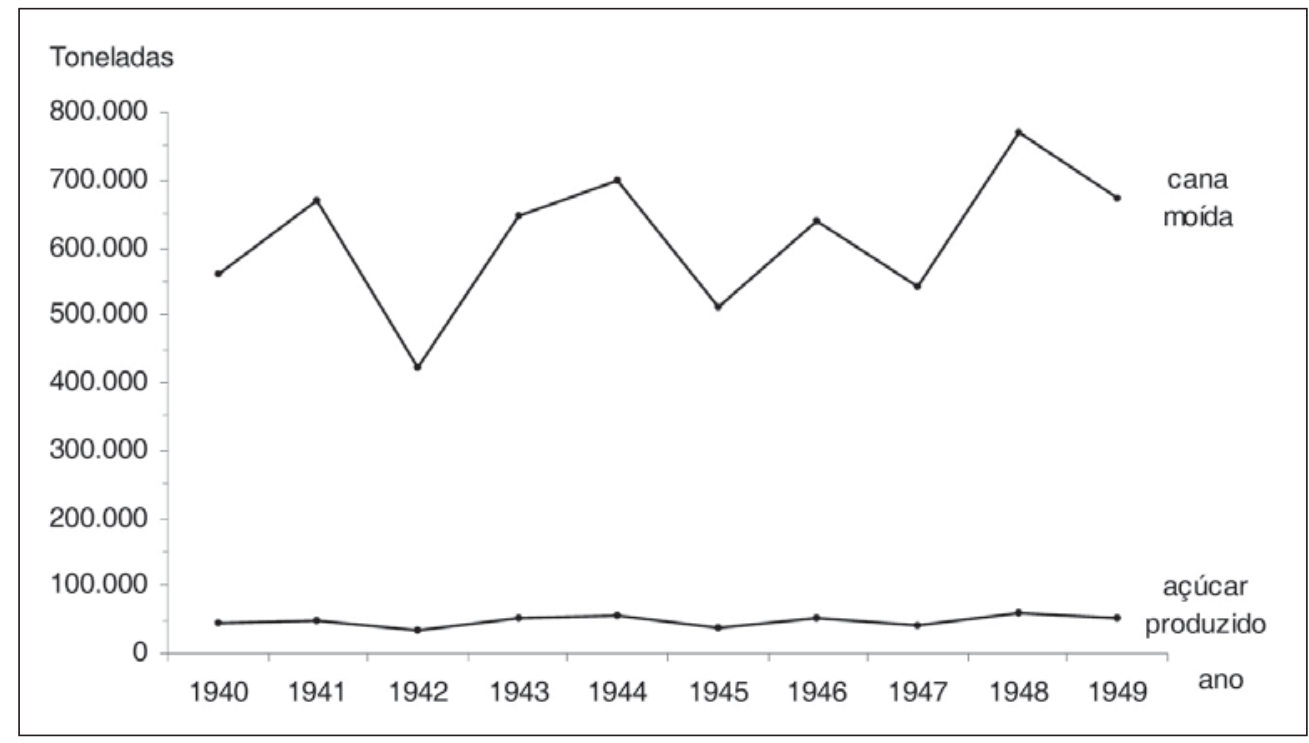

FONTE: Organizado por Brito (2004), com base em IBGE $(1947,1949,1951)$. 


\section{As relações sociais e de produção entre patrões usineiros/fornecedores de cana e trabalhadores canavieiros}

No que se refere às relações entre usineiros/fornecedores de cana e trabaIhadores canavieiros, a tradição de relações sociais e de produção baseadas em relações verticais, herdadas dos antigos senhores de engenho, cuja posição de mando, muitas vezes, transpunha os limites do engenho, conforme a importância do mesmo e da família, parece ter sido pouco modificada no Recôncavo Baiano, após mais de meio século da abolição do trabalho escravo e dos ventos da modernidade que sopravam sobre a República brasileira.

Como reflexo disso, as relações de trabalho contratuais pouco existiam, apesar de o Governo federal ter estabelecido um conjunto de leis em 1943 - a Consolidação das Leis do Trabalho (CLT) - que passou a regular as relações capital/ trabalho no país na qual se previa: o registro na carteira de trabalho, preço do salário mínimo, descanso semanal remunerado, jornada de trabalho limitada a oito horas diárias, horas extras, aposentadoria, contribuição para o benefício previdenciário e contribuição sindical.

A ignorância dos trabalhadores canavieiros - quase a totalidade dos canavieiros era analfabeta - frente aos direitos sociais garantidos pela legislação, pouco conhecida do grande público, e um sentimento de dependência pessoal ainda presente naquele meio social eram os fatores que possibilitavam os abusos dos patrões, usineiros e fazendeiros, que insistiam em não querer reconhecer os direitos trabalhistas dos seus funcionários.

Explorando a entrevista com alguns canavieiros aposentados de uma antiga usina de açúcar, ficou patente esse sentimento entre os ex-operários, ao afirmarem que o patrão era bom, dava casa para todos os empregados morarem e não cobrava nada; mantinha uma escola para as crianças estudarem de graça; mantinha um posto de saúde que atendia gratuitamente todos os moradores da vila operária; e quando a usina fechou, ele os deixou continuar morando no local sem pagar. Não sabiam os ex-operários que tudo aquilo integrava uma legislação de proteção social amparada pelo Decreto-Lei $n^{\circ}$ 6.969 , de 19 de outubro de 1944, baixado pelo IAA e mantida com recursos administrados por aquele órgão (INSTITUTO..., 1972).

O estado de pobreza extrema da maioria da população de canavieiros no Recôncavo Baiano era patente e conhecido por todos. Torres (1945), com base em pesquisa de campo sobre as condições de vida dos trabalhadores da agroindústria do açúcar no Brasil, em 1942, concluiu que os operários das usinas do Recôncavo Baiano eram os que recebiam, em média, os salários mais aviltantes 
da categoria no país, e que cerca de 70 a $80 \%$ da remuneração era comprometida com alimentação (Tabela 2)

Tabela 2 - Salário médio diário dos operários das usinas, segundo alguns estados do Brasil - 1942.

\begin{tabular}{l|c|c|c|c}
\hline \multirow{2}{*}{ Estados } & \multicolumn{2}{|c|}{ Média Rural } & \multicolumn{2}{c}{ Média Industrial } \\
\cline { 2 - 5 } & Cr\$ & U\$ & Cr\$ & U\$ \\
\hline São Paulo & 6,47 & 0,33 & 10,30 & 0,52 \\
Rio de Janeiro & 5,35 & 0,27 & 7,80 & 0,39 \\
Minas Gerais & 4,61 & 0,23 & 6,64 & 0,34 \\
Sergipe & 3,56 & 0,18 & 4,89 & 0,25 \\
Bahia & 3,20 & 0,16 & 4,65 & 0,23 \\
\hline
\end{tabular}

FONTE: Organizada por Brito (2004), com base em Torres (1945).

Os operários, tanto do campo como das usinas, percebiam salários inferiores à metade dos ordenados que recebiam seus colegas de categoria no estado de São Paulo, que eram os melhor remunerados da categoria no país. Contudo, uma parte muito diminuta dos operários das usinas no Recôncavo Baiano, chefe de cozimento e chefe de máquinas entre outros, percebia salários um pouco melhores que os demais, ou seja, apenas aqueles que tinham atingido postos de trabaIho importantes na fábrica, e já tinham dado um longo tempo de trabalho, de mais de 30 anos à usina, conforme declara Muricy (1946).

A explicação para uma remuneração tão baixa dos trabalhadores do açúcar no Recôncavo Baiano não pode ser creditada apenas à busca ilimitada da elevação da taxa de lucro e extração de maior quantidade possível de mais-valia da força de trabalho, por parte dos usineiros e fazendeiros, contra a menor remuneração possivel dos trabalhadores, mas deve ser levada em conta, também, a mentalidade escravista ainda presente nas mentes e nas ações dos usineiros e fazendeiros do Recôncavo Baiano.

Tal mentalidade era a base de todas as relações sociais e de produção no Recôncavo Baiano, fato que se revela sumamente importante para explicar a resistência dos patrões em atender, pelo menos, à recém-implantada "novidade" das demandas oficiais, referentes aos contratos de trabalho, tendo em vista esse novo elemento representar a possibilidade de rompimento da tradição do imaginário político-social dos patrões, fundado na relação entre a "casa grande e a senzala".

Essa parece ser uma questão comum a outros autores que também analisaram a história do Recôncavo Baiano, a exemplo de Brandão, (1997, p. 39) quando pergunta "ou será que não cabia, no tecido do poder, um trabalhador dono de si, fosse negro, fosse branco?"

Um exemplo significativo disso é a resposta dada por um dos diretores da LIR aos operários da usina Aliança quando inquirido sobre a necessidade de 
aumento dos salários que, apesar da possível ironia, servia tanto para desmobilizar a organização dos operários quanto refletir uma idéia paternalista: "[...] a S/A Magalhães não tinha dinheiro e que ele se sentia satisfeito ao ouvir uma queixa tão justa, disse mais: 'vocês são dono de tudo aqui a usina, barracões, pastos etc.'" (OS OPERÁRIOS..., 1949, p. 5).

No sentido de reagir a um regime de exploração extrema da força de trabalho e ao desrespeito à condição de trabalhador livre, a categoria dos operários das usinas de açúcar, cerca de 10.000 em Santo Amaro, organizou-se em um sindicato, fundado em 1935, mas somente reconhecido pelo Ministério do Trabalho em 1942, e registrado oficialmente no ano seguinte (CUNHA, 1995). Inicialmente, a base territorial do sindicato se restringia ao município de Santo Amaro e, socialmente, aos trabalhadores das usinas, ficando desprotegidos os trabalhadores de campo, ou seja, do canavial. Contudo, a intenção dos operários era estender a base espacial para todos os municípios canavieiros e englobar também os trabaIhadores de campo, o que dependia da legislação trabalhista.

De acordo com Cunha (1995), após a negativa de negociação entre os usineiros e os trabalhadores das usinas, sob a mediação da Delegacia Regional do TrabaIho (DRT), os operários do açúcar, sob a liderança do sindicato, realizaram em 1946 a sua primeira greve, que durou 15 dias, com base numa reivindicação de devolução de descontos ilegais relativos à habitação e higiene realizados pelos usineiros.

A Lei $n^{\circ} 4.780$, que trata dos assuntos relacionados às obrigações dos patrões para com os trabalhadores canavieiros tornava

[...] os produtores de cana, açúcar e álcool obrigados a aplicar, pelo Art. 36, em benefício dos trabalhadores industriais e agrícolas, em serviços de assistência médica hospitalar, farmacêutica e social, importância correspondente, no mínimo, a 1\% sobre o preço oficial do saco do açúcar, $1 \%$ sobre o valor oficial da tonelada de cana, e $2 \%$ sobre o valor oficial do litro de álcool de qualquer tipo. Estes recursos serão aplicados diretamente pelas usinas, destilarias e fornecedores de cana, individualmente ou através das respectivas associações de classe, mediante plano de sua iniciativa, submetido à aprovação e fiscalização do IAA (INSTITUTO..., 1972, p. 129).

Dessa maneira, os custos da habitação e higiene estavam cobertos pelo amparo legal do IAA, mas os patrões se apropriavam ilegalmente desses recursos públicos ao executarem esses descontos nos vencimentos dos trabalhadores.

Se os trabalhadores canavieiros acreditavam que a ilegalidade cometida pelos patrões consistia apenas na violação dos direitos trabalhistas, os patrões, por seu turno, tinham a certeza de que, além disso, eles estavam infringindo uma norma pactuada entre eles e o IAA, apropriando-se indevidamente de recursos públicos. 
Estava claro que essa "ousadia" dos operários das usinas de açúcar de Santo Amaro não poderia passar impunemente e, para isso, providências enérgicas teriam de ser diligenciadas para repelir essa rebeldia dos operários a fim de que isso não se repetisse no Recôncavo Baiano. Nesse sentido, a reação dos usineiros foi pragmática, aproveitando-se de uma conjuntura favorável, reclamaram junto à DRT a ilegalidade do sindicato, em decorrência da vigência do Decreto $n^{\circ}$ 9.070, de 15 de março de 1946, baixado pelo Presidente da República, Eurico Gaspar Dutra, mediante o qual era proibido qualquer tipo de manifestação política pública em defesa das massas, assim como, as reivindicações públicas dos sindicatos.

A formulação do Decreto n 9.070, com o qual foram amordaçados, à época, os movimentos sociais organizados, amparava-se na emenda constitucional elaborada pelo deputado constituinte de 1946 pela Bahia, Clemente Mariani. Essa emenda à Constituição Federal de 1946 era estritamente discricionária, proibia o funcionamento de partidos políticos "seguidores de doutrinas consideradas antidemocráticas e extremistas". Tal emenda foi elaborada especialmente para cancelar o registro do Partido Comunista Brasileiro (PCB), logo no início da "guerra fria" - o PCB que em sua política de alianças dava apoio ao governo do presidente Dutra.

Com isso, no início do ano seguinte, após a promulgação da Constituição de 1946, a ordem foi de destituir - ilegalmente, pois a DRT acompanhou todo o processo de negociação entre as partes - a diretoria eleita do sindicato e em seu lugar empossar uma Junta Interventora, nomeada pelo Ministério do Trabalho. De sua parte, a LIR se encarregou de perseguir os membros da diretoria do sindicato, demitindo todos os seus diretores de seus empregos nas usinas do Recôncavo Baiano; a contenda estava formada.

Com o PCB na ilegalidade e sem seu instrumento político de reivindicação de seus direitos e temendo represálias mais agressivas dos patrões, os operários do açúcar foram desmobilizados e tiveram de se submeter aos desejos e às paixões dos patrões. ${ }^{6}$

Sob a tutela da DRT, o Sindicato dos Trabalhadores na Indústria do Açúcar de Santo Amaro, omisso frente aos problemas da categoria, já não representava mais os interesses dos trabalhadores canavieiros. Em virtude disso e da clandestinidade, a nova estratégia de ação do PCB para o seu público alvo era a ação por meio de entidades paralelas, organizando os proletários diretamente nos locais de trabalho, e entre os canavieiros não foi diferente (CUNHA, 1995).

\footnotetext{
${ }^{6}$ O PCB tinha uma importante influência política entre os operários das usinas, nas eleições parlamentares de janeiro de 1947 elegeu dois representantes, um para a Assembléia Legislativa estadual e outro para a Câmara Federal.
} 
Em 21 de abril de 1948, foi fundada a Sociedade União dos Artífices Santamarenses (SUAS), um tipo de sociedade civil prevista na CLT, através da qual os canavieiros passariam a reivindicar diretamente suas demandas junto aos patrões. A SUAS, que estava registrada formalmente no município de Santo Amaro, agia na formulação de pautas de reivindicações denominadas memoriais as quais eram entregues aos patrões por meio das comissões de fazendas e de usinas (CUNHA, 1995).

A vontade e a necessidade de conquistar os direitos oficialmente garantidos, todavia negados pelos patrões do açúcar, fizeram com que, no início do ano de 1949, a categoria dos operários retomasse o processo de mobilização, através de reivindicações de seus direitos, com a apresentação direta de memoriais aos usineiros. A primeira usina a passar por essa experiência de mobilização operária foi a São Carlos, da LIR, que no mesmo dia, 11 de janeiro 1949, chamou a polícia para dentro da usina para impedir a entrega do memorial aos dirigentes da mesma. De maneira respeitosa os trabalhadores canavieiros apresentaram o memorial,

Nós, abaixo assinados, trabalhadores desta usina, considerando que o artigo 29 na consolidação trabalhista determina a assinatura das carteiras profissionais, no prazo de 24 horas, por parte do empregador, o que não vem acontecendo nesta usina; considerando que existem inúmeras carteiras profissionais retidas em mão da gerência, quando a lei determina devolução imediata aos seus respectivos donos; considerando que o gozo de férias é direito mundial dos trabalhadores, o qual nos é assegurado pela consolidação trabalhista e pela constituição da República, o que não vem sendo cumprido pela usina; considerando que muitos trabaIhadores não possuem carteiras profissionais e se sentem impossibilitados de as tirarem; considerando que os trabalhadores quando são despedidos da usina não recebem aviso prévio e não são indenizados de acordo com a lei; considerando que o preço de $\mathrm{Cr} \$ 3,50$ [U\$ 0,2] por tonelada de cana cortada não compensa ao trabalho ao nível de vida atual, porque um homem trabalhando 12 horas por dia corta 3 toneladas de cana, fazendo uma diária de Cr\$10,50 [U\$ 0,7]; vimos muito respeitosamente, através deste memorial, pedir a V. S. que se digne a conceder as seguintes reivindicações: a) Assinaturas nas carteiras profissionais a contar da data que foi admitido no trabalho; b) devolução das carteiras a seus respectivos donos depois de assinadas; c) pagamento das férias atrasadas e atuais; d) aquisição de carteiras profissionais para os que não as possuem por intermédio da usina; e) pagamento integral das indenizações determinadas por lei inclusive férias e aviso prévio dos que forem dispensados da usina; f) pagamento de $\operatorname{Cr} \$ 5,00$ [U\$ 0,3], no mínimo, por tonelada de cana cortada (LUTAM..., 1949, p. 5, acréscimos nossos).

Após uma semana, diante da resposta contrária dada pelos diretores da usina às reivindicações dos operários, que tiveram a justeza reconhecida inclusive pelo fiscal da DRT que estava presente durante o ato da entrega do memorial, os canavieiros decidiram entrar em greve. Em represália, os diretores da usina ordenaram imediatamente o aumento dos preços dos alimentos vendidos no barra- 
cão e suspenderam a compra por meio de "vale"7. Após três dias de paralisação, os patrões ofereceram os termos da negociação: a usina pagaria as férias dos três últimos anos no prazo de 30 dias; as carteiras profissionais seriam assinadas e devolvidas; os empregados demitidos seriam indenizados; e, por fim, nenhum trabalhador seria perseguido por ter participado da greve (MUNIZ, 1949, p. 1, 8).

Os trabalhadores aceitaram a proposta e condicionaram o fim da greve à assinatura de um documento no qual constavam os termos do acordo. Contudo, os patrões protelaram e não assinaram o documento, No dia seguinte, quando discursavam para os operários paralisados da usina, os diretores da SUAS foram presos pela polícia a mando do diretor da usina.

Com isso, os grevistas foram, em passeata, até a delegacia da cidade de Santo Amaro reclamar a liberação dos líderes do movimento, mas acabaram recebidos a bala pela polícia, resultando num saldo de dois operários mortos e onze feridos. Pelas circunstâncias do ocorrido, os diretores da usina previam a desmobilização imediata dos grevistas com as prisões e a violência levada a cabo pela polícia. Mas, diante da repercussão negativa junto à opinião pública, inclusive da capital, a firma cedeu em parte às reivindicações dos operários e comprometeu-se a realizar o pagamento de férias vencidas e assinatura das carteiras de trabalho e, dias depois, os operários presos ilegalmente foram postos em liberdade.

Esse tipo de ação violenta praticada pelo aparelho do Estado em suas distintas escalas, em consonância com os interesses dos usineiros, não foi suficiente para intimidar os operários do açúcar em Santo Amaro, pois tudo para eles estava perdido e carecia ser conquistado. Dessa maneira, novas mobilizações de reivindicações ocorriam em várias outras usinas, com os operários sendo tratados de maneira semelhante.

Os fatos ocorridos na usina São Carlos servem para ilustrar o tipo de relação social e de produção que existia entre os patrões e os empregados no Recôncavo açucareiro, que em nada se aproximava de soluções mediadas por acordos, por concessões de parte a parte, mas sim, por via de coação e violência perpetradas pelos agentes que dispunham dos meios e das condições de impor suas paixões e desejos aos que por estes eram subjugados.

Vê-se, dessa maneira, que, no Recôncavo açucareiro diante dos usineiros, fornecedores de cana, o Governo e os operários do açúcar, quem exercia a posição de mando eram os usineiros e esse fato, como já discutido no início,

\footnotetext{
${ }^{7} \mathrm{O}$ "vale" era uma forma de compra a prazo, por meio do qual os operários das usinas adquiriam os alimentos nos armazéns das usinas, a preços de monopólio; no fim do mês, a quantia adiantada pelo patrão era descontada no pagamento dos operários. Era também através do vale que os operários se endividavam e permaneciam presos ao emprego nas usinas, pois a circulação monetária era a mínima possível implicando a escassez de alternativas à sobrevivência de parte da população.
} 
não Ihes atribuía qualquer característica que lhes levasse à condição de hegemonia, pois as ações que permeavam as relações sociais não resultavam de consensos, mas sim, de coações e, sendo assim, forçosamente o poder estava quase ausente nas várias formas de relações entre os referidos agentes.

Condições semelhantes, mas com menor rigidez, também se repetiam na zona do fumo, adjacente à área açucareira. 



\section{As relações sociais e de produção entre os agentes e suas implicações espaciais no Recôncavo Fumageiro}





\section{As relações sociais e de produção entre os agentes e suas implicações espaciais no Recôncavo Fumageiro}

De maneira complementar à economia açucareira, a fumicultura foi introduzida nas partes mais periféricas das terras do Recôncavo Baiano, nas áreas mais secas e de solos mais pobres, entre a caatinga e os canaviais. Até a primeira metade do século XX, o cultivo do fumo achava-se distribuído nos seguintes municípios: Santo Antônio de Jesus, Conceição do Almeida, Cruz das Almas, São Felipe, Maragogipe, São Félix, Cachoeira, Conceição da Feira e Conceição do Jacuípe.

No fim da primeira metade do século $\mathrm{XX}$, assim como o açúcar, o fumo no Recôncavo Baiano também já vinha perdendo a importância comercial que outrora desfrutava no mercado internacional. A desaceleração e a conseqüente crise em que sucumbiu a fumicultura baiana a partir da década de 1950 deveu-se principalmente à

\footnotetext{
[...] derrocada da Alemanha no último conflito mundial. As empresas sediadas na Bahia, mesmo de propriedade de brasileiros, estavam sempre ligadas ao capital estrangeiro, principalmente o alemão, principal intermediário entre os grupos estrangeiros e a Bahia. Com o final do conflito as empresas exportadoras alemãs enfrentaram sérias dificuldades, decorrentes, sobretudo da retração do mercado germano. Esta retração permite a entrada de empresas norte-americanas na concorrência do fumo, como a Suerdieck, por exemplo, que passa a intensificar o intercâmbio comercial com alguns países africanos como a Rodésia e o Malaui, Zâmbia e Angola, que despontam no cenário internacional da produção nos fins da década de 1950 (SANTOS, V., 1990, p. 58-59).
}

Cultural e socialmente, a atividade fumageira sempre teve pouco prestígio, era lavoura de pobre e, por isso, as relações sociais e de produção na fumicultura, nesse período, eram menos rígidas que na zona canavieira, mas ainda sob o jugo de relações paternalistas entre patrões e empregados, tais como as que se davam nas usinas. O acesso à terra para cultura do fumo e as formas como os parceiros se relacionavam para produzir o fumo eram mais flexíveis, fato disso é que nessa época, em geral, nos municípios fumageiros, a propriedade da terra estava menos concentrada, conforme se pode verificar no Gráfico 1. Nesse gráfico, se destacam especialmente os municípios: Cruz das Almas (27\%), Muritiba $(13,7 \%)$, São Gonçalo dos Campos (13,6\%), Conceição do Almeida (12,1\%) e Santo Antônio de Jesus $(7,8 \%)$ que compunham os cinco maiores produtores de fumo no Recôncavo Baiano, em ordem decrescente de importância e nos quais se registram os menores índices de concentração da propriedade da terra. Igual- 
mente nesses municípios, ao lado das plantações de fumo, cultivava-se a pequena produção de alimentos, além da criação de animais, tudo de maneira relativamente pulverizada.

Ao contrário da zona açucareira, que tendia sempre à concentração da propriedade fundiária com as usinas, na área da fumicultura, as várias formas de parceria e arrendamento eram as modalidades básicas de exploração da terra, implicando a tendência a um excepcional aumento da utilização do estabelecimento facilitada pela existência de várias unidades de produção dentro da mesma fazenda. Ao invés de levar a um processo de fragmentação da propriedade da terra, esse fato fazia aumentar os lucros dos fazendeiros, que pouco investiam e impunham aos seus parceiros e arrendatários a exclusividade da precedência da compra, da parte do fumo que lhes pertencia, certamente, a preços vis (COSTA PINTO, 1958).

A pobreza de grande parte da população, que se dedicava à lavoura do fumo, e a forte relação de dependência pessoal que unia os parceiros ao fazendeiro, condicionavam as relações de comando/obediência entre lavradores e fazendeiros, em face da posição chave destes implicando a:

[...] obrigação que tem os seus parceiros de vender a êle a parte que lhes toca do produto de seu trabalho - questão fechada, norma ínviolável, cujo desrespeito merece não apenas ser punido como rutura de um contrato; quem o fizer, é merecedor de verdadeira expiação, por infidelidade e traição, justificando ser expulso das terras sem remissão e a pecha de ingrato (COSTA PINTO, 1958, p. 51).

Esse acordo leonino entre fazendeiros e lavradores de fumo revela o tipo de relação vertical predominante entre esses agentes, que não permite aos lavradores a escolha entre outros compradores da produção de fumo existente no mercado local.

Diante das vantagens auferidas nas relações de produção com seus parceiros, por dispor de grande quantidade de fumo, geralmente, os fazendeiros tornavam-se também comerciantes, realizando um primeiro beneficiamento do fumo ainda na fazenda, em seus trapiches; em seguida, fechavam os contratos comerciais com as casas exportadoras sediadas na cidade do Salvador que, ao contrário do açúcar, eram controladas por comissários estrangeiros - alemães principalmente - conforme explica Guimarães (1982). Localmente, eles abasteciam parte das fábricas de charutos nas cidades do Recôncavo Baiano. As grandes fábricas de charutos e cigarros dispunham de fazendas com plantações próprias de fumo de melhor qualidade, tanto para o próprio abastecimento como para exportação.

Devido à própria natureza da lavoura do fumo, além do fazendeiro-trapicheiro, também existia uma grande quantidade de intermediários - comissários - que 
agiam junto aos lavradores, e que também impunha regras muito duras aos lavradores, de acordo com sua posição e capacidade de compra. Entre os intermediários se destacavam:

a) comprador avulso de pequenas posses, que compra o fumo em pequenas quantidades e vai armazenando em casa para depois passar a um outro intermediário com maior poder aquisitivo às vezes, um comprador/vendedor de charutos;

b) comprador avulso de posses médias que armazena em casa e transfere o fumo direto para o armazém de trapiche;

c) proprietários de armazéns de secos e molhados na zona rural, que também vai comprando o fumo da vizinhança, para depois passar direto ao armazém;

d) comprador estabelecido na zona rural com um depósito ou pequeno armazém de trapiche, repassando direto ao armazém na sede do município;

e) a compra direta armazém-produtor, principalmente dos grandes produtores. $[\ldots] ;$

f) o último elo da cadeia é o comprador estrangeiro, que na realidade é quem dita as regras do jogo (SANTOS, V., 1990, p. 61).

Muitas cidades do Recôncavo Baiano, dentre as quais Maragogipe, Cachoeira, Cruz das Almas, Muritiba e São Félix sediavam as mais importantes manufaturas de fumo e/ou fábricas de charutos. Nessas fábricas e demais armazéns, a força de trabalho era preferencialmente feminina, cujos patrões e chefes praticavam toda sorte de abusos.

A precarização do trabalho e a pobreza eram uma realidade presente, tanto na lavoura quanto na manufatura do fumo. Na fazenda, era a relação de lealdade - dependência pessoal - que determinava os laços sociais e de produção entre o fazendeiro e seus parceiros, resultando em vantagens econômicas e políticas, fruto do prestígio social de que gozava o primeiro. Esse cadinho cultural forjava o paternalismo que, por sua vez, reproduzia o patrimonialismo (FAORO, 1987; MARTINS, J., 1994) no nível geral da sociedade amalgamada pelas relações de dependência pessoal.

Embora mais flexíveis, as relações entre os agentes sociais nem por isso deixavam de ser reguladas diariamente por ações de dominação, especialmente nas manufaturas e fábricas de charutos. Referindo-se às condições de trabalho dentro dos armazéns, uma manufatura de fumo, o jornal $O$ Momento relata que "Dentro dos armazéns impera ainda o velho regime das senzalas e a falta de higiene é a mais clamorosa. O mestre leva, durante todo o dia, percorrendo as dependências desrespeitando, xingando, censurando e suspendendo os operários" (OS TRABALHADORES..., 1946, p. 5-6).

Quanto à assistência médica prevista pela CLT denuncia, ainda, o diário, 
[...] vamos citar um fato concreto: uma charuteira da fábrica Suerdieck, filial de Cachoeira, estando nos últimos dias de gravidês, pediu a uma companheira para informar-se na fábrica acêrca do direito ao benefício. Atendeu-a um Sr. Melo, empregado nos escritórios da dita companhia. Tratou-a, como de costume, grosseiramente, e mandou dizer à operária gestante que ela não tinha direito a coisa nenhuma, e mais: que tomasse vergonha e deixasse de parir (OS TRABALHADORES..., 1946, p. 5-6).

Como se percebe, também nas fábricas de charutos as relações entre os agentes sociais estavam embotadas pela tradição do comando/obediência, em que as mediações orientadas pelo consenso, se existiam, dependiam exclusivamente do temperamento e das relações de compadrio de quem estava no exercício da posição de mando.

\section{Um agente completamente novo e externo passa a interagir com os demais no Recôncavo Baiano: o CNP}

A insistência na referência à atividade açucareira deve-se ao fato de que essa atividade, dentre as demais, era a mais importante no Recôncavo Baiano, desde a sua origem até o período em análise, mesmo com toda a estagnação predominante na vida social, política e econômica regional.

Apesar de o açúcar produzido no estado da Bahia não ter feito parte da cesta de mercadorias direcionadas para o mercado externo, ao longo da década de 1940, e ter sido "riscado" completamente desse mercado nos períodos subseqüentes, é provável que, ainda assim, tenha garantido boa fatia de lucro aos usineiros e a seus credores, pois no comércio interestadual o açúcar produzido nas usinas do Recôncavo Baiano se fez presente com preços muito próximos e até, algumas vezes, maiores que os praticados no comércio exterior, em certos períodos (Tabela 3). Além disso, o preço do açúcar no comércio varejista na Bahia era controlado pelo monopólio da firma S/A Magalhães, cujas usinas pertencentes ao grupo eram responsáveis por mais de $80 \%$ do açúcar produzido no Recôncavo Baiano.

Tabela 3 - Bahia: quantidade exportada (t) e preço (U\$/t) do açúcar no comércio interestadual - 1940/1948

\begin{tabular}{c|c|c|c|c|c|c|c|c|c}
\hline \multicolumn{10}{c|}{ Ano } \\
\hline \multicolumn{1}{c|}{1940} & \multicolumn{2}{c|}{1941} & \multicolumn{2}{c}{1942} & \multicolumn{2}{c}{1943} & \multicolumn{2}{c}{1944} \\
\hline t. & U\$/t & t. & U\$/t & t. & U\$/t & t. & U\$/t & t. & U\$/t \\
\hline 26.778 & 37,00 & 22.957 & 39,00 & 1.444 & 44,00 & 18.203 & 65,00 & 23.201 & 76 \\
\hline
\end{tabular}


conclusão

\begin{tabular}{c|c|c|c|c|c|c|c|c|c}
\hline \multicolumn{10}{c|}{ Ano } \\
\hline \multicolumn{2}{c|}{1945} & \multicolumn{2}{c|}{1946} & \multicolumn{2}{c|}{1947} & \multicolumn{2}{c}{1948} & \multicolumn{2}{c}{1949} \\
\hline $\mathrm{t}$ & $\mathrm{U} \$ / \mathrm{t}$ & $\mathrm{t}$ & $\mathrm{U} \$ / \mathrm{t}$ & $\mathrm{t}$ & $\mathrm{U} \$ / \mathrm{t}$ & $\mathrm{t}$ & $\mathrm{U} \$ / \mathrm{t}$ & $\mathrm{t}$ & $\mathrm{U} \$ / \mathrm{t}$ \\
\hline 16.385 & 91,00 & 5.472 & 115,00 & 6.683 & 134,00 & 8.479 & 135,00 & $\ldots$ & $\ldots$ \\
\hline
\end{tabular}

FONTE: Organizada por Brito (2004), com base em dados do IBGE $(1947,1949,1951)$.

Na década de 1940, a produção de açúcar pelas usinas do Recôncavo Baiano era mantida baixa intencionalmente, mas a produção de 1942 foi excepcionalmente baixa, provocada pela grande seca ocorrida nesse ano.

Embora muito baixa em relação às mais importantes regiões produtoras do País (Tabela 4), a produção de açúcar das usinas do Recôncavo Baiano não era desprezível, ante a possibilidade de extração de lucros do negócio açucareiro pelos usineiros e financistas, que se utilizando de práticas arcaicas, se serviam desse artifício, sempre que possível, para obtenção de benefícios governamentais. Um outro aspecto já comentado diz respeito às maneiras costumeiras de geração de lucros fabulosos numa atividade decadente. Isso Ihes permitia continuar na atividade açucareira.

Tabela 4 - Produção de açúcar (mil t) pelas usinas nas principais regiões brasileiras produtoras - 1940/1949

\begin{tabular}{l|c|c|c|c}
\hline \multirow{2}{*}{ Ano } & \multicolumn{4}{|c}{ Estados } \\
\cline { 2 - 5 } & Bahia & Pernambuco & Rio de Janeiro & São Paulo \\
\hline 1940 & 45.142 & 335.771 & 149.672 & 139.813 \\
1941 & 49.407 & 282.129 & 174.971 & 134.382 \\
1942 & 35.267 & 263.966 & 168.345 & 175.845 \\
1943 & 52.114 & 296.165 & 139.169 & 177.508 \\
1944 & 55.232 & 296.779 & 180.480 & 183.853 \\
1945 & 38.686 & 294.920 & 205.328 & 175.072 \\
1946 & 51.172 & 329.056 & 187.690 & 272.766 \\
1947 & 42.857 & 382.190 & 217.468 & 322.883 \\
1948 & 59.791 & 483.933 & 234.676 & 348.847 \\
1949 & 51.213 & 455.589 & 234.295 & 358.483 \\
\hline
\end{tabular}

FONTE: Organizada por Brito (2004), com base em dados do IBGE (1947, 1949, 1951).

Uma explicação palpável para a irregularidade e à baixa produção anual de açúcar pelas usinas do Recôncavo Baiano e de sua consequente débâcle a partir da década de 1950 está ligada à conjunção de vários fatores de ordem técnica, econômica e política, que influenciaram negativamente no negócio do açúcar, no Recôncavo Baiano, a saber:

a) apesar de uma usina de açúcar ser composta pela fábrica e fazendas de cana próprias e de terceiros, os seus proprietários e fornecedores não destinavam a 
atenção necessária à lavoura. A esse respeito, Silva, J. (1973) explica, de maneira detalhada, as causas da ineficiência e da conseqüente baixa produtividade da lavoura da cana no Recôncavo Baiano. As explicações são de cunho mais técnico e se referem à ausência, quase absoluta, de utilização de técnicas de manejo adequadamente desenvolvidas; mecanização e uso de fertilizantes químicos e/ ou orgânicos; insistência na utilização de plantas de baixa produtividade e de baixo teor sacarífero; alto grau de analfabetismo da força-de-trabalho, na lavoura e na indústria; esgotamento dos solos, dentre outras;

b) as vias internas de transporte no Brasil (ligação entre as regiões (atualmente) Nordeste e Sudeste, sobretudo) quase inexistiam na década de 1940 até a implantação e a pavimentação da rodovia federal BR-116 (Rio/ Bahia), iniciada em 1949 e concluída em 1963, e depois a BR-101 em 1972. As estradas de ferro eram, igualmente, precárias e sem capacidade de expansão, o que praticamente impedia as trocas de mercadorias entre a Bahia e os estados do Sudeste e Sul. Dessa maneira, a maior parte do intercâmbio de mercadorias do comércio interestadual era realizada através da navegação de cabotagem, que, por sua vez estava sob o controle da firma S/A Magalhães e do grupo econômico do Conde Matarazzo (GNACCARINI, 1989).

Contudo, com o advento da Segunda Guerra, essa modalidade de transporte limitou bastante as trocas comerciais entre a Bahia e os estados das Regiões Sudeste e Sul, especialmente, São Paulo, um grande mercado de açúcar em rápida expansão, tendo em vista o temor de afundamento de embarcações pelas potências beligerantes (SZMRECSÁNYI, 1979);

c) os usineiros do estado de São Paulo, cuja produção de açúcar estava amarrada às cotas determinadas pelo Instituto do Açúcar e do Álcool (IAA), desde 1935, sentiam-se em franca desvantagem em relação aos seus concorrentes do Nordeste. Assim, num momento de conjuntura politicamente difícil para o IAA, os usineiros de São Paulo chegaram a sugerir até a extinção desse órgão. Através de negociações, os referidos usineiros conseguiram obter a liberação total das quotas de produção de açúcar a partir de 1942 e passaram a realizar grandes investimentos nas lavouras e nas usinas, disputando a liderança de produção nacional de açúcar e de álcool com os usineiros de Pernambuco (SZMRECSÁNYI, 1979).

Com a liberação das quotas de produção de açúcar, outros estados também puderam abastecer-se internamente com produção própria. Como consequência, a participação do açúcar baiano nas trocas interestaduais passou a ser cada vez menor. Internamente, no estado da Bahia, o preço do salário dos operários era muito inferior ao recebido pelos operários da região Sudeste, isso atuava como um umbral intransponível à expansão do consumo do açúcar e também para elevar a capacidade de compra de mercadorias dos operários baianos. 
Num período de inflação elevada, como foi toda a década de 1940, o salário mínimo mensal determinado pelo Governo Federal em Salvador e no Recôncavo Baiano era o mais baixo, tendo como referência os estados do Rio de Janeiro, São Paulo e Bahia. No fim da década, para agravar ainda mais a compressão salarial dos operários canavieiros e demais categorias de trabalhadores baianos, houve uma redução do preço do salário mínimo na Bahia, enquanto nos outros dois estados citados o salário mínimo até aumentou, como se pode constatar na Tabela 5.

Tabela 5 - Preço do salário mínimo mensal em três capitais brasileiras escolhidas e nas zonas canavieiras dos respectivos estados - 1944/46 e 1949

\begin{tabular}{|c|c|c|c|c|c|}
\hline \multirow{2}{*}{ Capitais } & \multicolumn{2}{|c|}{ Salário Mínimo (U\$) } & \multirow{2}{*}{$\begin{array}{c}\text { Zonas } \\
\text { Canavieiras }\end{array}$} & \multicolumn{2}{|c|}{ Salário Mínimo (U\$) } \\
\hline & $1944 / 46$ & 1949 & & $1944 / 46$ & 1949 \\
\hline Salvador & 15,4 & 12,8 & Recôncavo & 11,8 & 10,4 \\
\hline Distrito Federal & 19,5 & 20,3 & Campos & 12,6 & 13,1 \\
\hline \multirow[t]{2}{*}{ São Paulo } & 18,5 & 19,2 & Piracicaba/ & & \\
\hline & & & Ribeirão Preto & 14,1 & 14,7 \\
\hline
\end{tabular}

FONTE: Organizada por Brito (2004), com base em dados do IBGE $(1947,1951)$.

Como resultado da baixa produção de açúcar nas usinas e das estratégias de liquidação de usineiros e fornecedores de cana utilizadas pela firma subsidiária da S/A Magalhães, seis das 19 usinas existentes em 1942 encerraram suas atividades em 1949; em 1951, mais duas também fecharam; em 1954, já havia uma a menos; em 1956, existiam apenas nove usinas; em 1965, reabre uma e passam a existir dez usinas; mas em 1972 esse número cai para a metade; em 1974, diminui para quatro; em 1986 fecha mais uma; no ano de 2000 continuam três usinas; e finalmente em 2002, resta somente uma usina. Não é de estranhar que todas as usinas controladas pela firma S/A Magalhães tenham atravessado a década de 1940, pois, de qualquer modo, aquela firma tinha recursos suficientes para enfrentar crises, e além do mais era controladora de usinas de açúcar em Campos-RJ, no interior de São Paulo, Alagoas, Pernambuco e outros estados produtores de açúcar na região Nordeste.

Com grande parte das usinas em estado de "fogo morto", já na segunda metade da década de 1940, o capital empregado na atividade açucareira apresentava os estertores de seu processo de reprodução. A atividade açucareira se mantinha de maneira quase que especulativa e, nessa senda, diante da grave crise que pairava sobre a economia regional, associada à aceleração progressiva da escassez de empregos, e ainda por não dispor dos meios de sua reprodução, tendo em vista que, quase a totalidade das terras pertencia aos usineiros e fazendeiros, a população passou, então, a migrar preferencialmente para a capital da Bahia. 
Em 1950, entre o crescimento natural e os saldos de imigração, a população do município de Salvador somou um contingente de 127.235 habitantes a mais sobre a população existente em 1940.

No período entre 1940 e 1950, os municípios de Salvador, Camaçari, Cruz das Almas, Muritiba e Santo Antônio de Jesus registraram crescimento demográfico superior a 10\%; entre os demais municípios, alguns tiveram incremento modesto, e outros decresceram, com destaque para os municípios canavieiros, a exemplo de Santo Amaro e São Francisco do Conde, os quais registraram uma diminuição substancial da população, além de Pojuca, na parte Norte do Recôncavo Baiano (Tabela 6).

Tabela 6 - Recôncavo Baiano: evolução da população total por municípios - 1940/1950

\begin{tabular}{|c|c|c|c|}
\hline \multirow{2}{*}{ Municípios } & \multicolumn{2}{|c|}{ População } & \multirow{2}{*}{$\begin{array}{c}\text { Evolução } \\
\text { 1940/1950 (\%) }\end{array}$} \\
\hline & 1940 & 1950 & \\
\hline Salvador & 290.000 & 417.235 & 43,8 \\
\hline Camaçari & 11.188 & 13.800 & 19,0 \\
\hline Cruz das Almas & 28.255 & 32.276 & 12,5 \\
\hline Muritiba & 28.135 & 31.605 & 11,0 \\
\hline Santo Antônio de Jesus & 26.466 & 29.668 & 10,8 \\
\hline Itaparica & 19.378 & 21.433 & 9,6 \\
\hline Conceição de Feira & 9.731 & 10.532 & 7,6 \\
\hline Mata de São João & 16.672 & 17.651 & 5,5 \\
\hline Catu & 17.222 & 16.437 & 4,8 \\
\hline Maragogipe & 35.095 & 36.868 & 4,8 \\
\hline São Sebastião do Passé & 20.303 & 21.135 & 3,9 \\
\hline Aratuípe & 6.141 & 6.351 & 3,3 \\
\hline São Felipe & 25.917 & 25.343 & 2,3 \\
\hline Nazaré & 24.332 & 24.405 & 0,3 \\
\hline Jaguaripe & 10.390 & 10.403 & 0,1 \\
\hline São Félix & 14.851 & 14.801 & $-0,3$ \\
\hline Cachoeira & 26.966 & 26.816 & $-0,5$ \\
\hline São Gonçalo dos Campos & 31.431 & 30.830 & $-1,9$ \\
\hline Conceição do Almeida & 27.261 & 25.407 & $-7,3$ \\
\hline Santo Amaro & 106.303 & 85.739 & $-24,0$ \\
\hline São Francisco do Conde & 14.157 & 11.077 & $-27,8$ \\
\hline Pojuca & 10.009 & 6.911 & $-44,8$ \\
\hline Total do Recôncavo & 800.203 & 916.723 & 12,7 \\
\hline
\end{tabular}

FONTE: Organizada por Brito (2004), com base em IBGE (1950 e 1955).

No processo migratório de parte da população do Recôncavo Baiano que se consolida a partir dos anos 1940, a cidade de Salvador foi a principal área de recepção do excedente demográfico. Todavia, sem dispor de uma infra-estrutura 
adequada e também mergulhada no tal "enigma baiano", essa população adicional passou a habitar as partes mais mal localizadas da cidade, vindo a erigir os bairros periféricos e pobres da antiga cidade 8 .

A crise secular que se generalizava no Recôncavo Baiano e no estado da Bahia como um todo estava instalada, mas não totalmente definida. É nessa atmosfera econômica e política rarefeita e de acelerado declínio da importância dos usineiros e dos demais agentes econômicos regionais que um agente completamente novo, o Conselho Nacional de Petróleo (CNP) vai colocando cunhas nas clivagens expostas da estrutura política, social e econômica arcaicas do Recôncavo Baiano.

O CNP é um órgão do Governo federal criado pelo Decreto-Lei n 395, de 29 de abril de 1938 (COHN, G., 1968), e vinculado diretamente à Presidência da República, devido à natureza extremamente estratégica (econômica e militar) do petróleo como combustível. O CNP tinha como meta gerir e executar todas as atividades ligadas a produção, controle e distribuição do petróleo e seus derivados no país por meio do seu instrumento legal - o Decreto-Lei ${ }^{\circ} 538$ de 7 de julho de 1938 (COHN, G., 1968).

As ações do CNP no Recôncavo Baiano também eram eminentemente verticais em relação aos demais agentes, fazendeiros, usineiros e operários do petróleo.

Na busca do cumprimento de seus objetivos, em qualquer lugar que apresentasse a possibilidade de existência de petróleo no subsolo (das fazendas produtivas ou não, o que gerava sempre destruição e/ou contaminação do que estava na superfície da terra e que desagradava os proprietários pelos baixos valores recebidos por indenização), esse órgão não media esforços para pesquisálo e, a partir da constatação de sua existência, passar a explorar o óleo e/ou o gás natural.

A necessidade de gerar a maior quantidade possível de oferta do óleo produzido internamente, no Brasil, era premente. As questões econômicas em torno da tendência ao forte aumento do consumo de petróleo e seus derivados no país pressionavam o Governo a evitar ao máximo os elevados custos de importação de óleo e derivados. Segundo mensagem do Governo federal enviada ao Congresso Nacional com projeto de criação da Petrobras, em 1951, "o valor das importações de petróleo e derivados que, em 1939, correspondem a 7\% do

\footnotetext{
${ }^{8}$ O termo "enigma baiano" foi cunhado pelo governador da Bahia, Otávio Mangabeira (1947-1951), para se referir ao estágio de letargia pelo qual passava a economia baiana, que se reproduzia especulativamente. Mangabeira, vinculado ao setor mercantil baiano, sentiu-se surpreso ao perceber que, apesar da grande possibilidade de geração de riqueza na Bahia devido à generosidade da natureza, seu povo vivia em condições de pobreza. Apesar de uma certa sensibilidade e sentimento de inconformidade demonstrada pelo discurso do governador, Guimarães (1982, p. 100) sintetiza-o: "Seu diagnóstico é claro, preciso, minucioso mas superficial e abstrato, como convém a um discurso ideológico, pois é nesse nível que se acham os elementos de consenso".
} 
valor da totalidade de nossas aquisições externas, em 1946 representou 7,6\% e, em 1950, 11,3\%" (COHN, G., 1968, p. 131). De outro modo, as implicações negativas da dependência externa do óleo e seus derivados não eram bem vistas pelos estrategistas militares do governo, que tinham uma inclinação nacionalista, tendo em vista, ainda, a conjuntura de guerra que se estava atravessando.

A partir dessa premissa e pela finalidade atribuída ao CNP, não havia em sua frente qualquer tipo de obstáculo que lhe dificultasse a busca do petróleo, fato que justificava a necessidade de descobrir e extrair o óleo onde quer que ele pudesse ser encontrado. Isso era mais importante que os direitos individuais dos fazendeiros e usineiros do Recôncavo Baiano, ainda que legítimos.

Apesar de a descoberta do petróleo no Recôncavo Baiano - por acaso, por Oscar Cordeiro - ter ocorrido em 1938, o início de sua exploração econômica somente foi possível a partir de 1941, com as descobertas dos campos de Candeias e Itaparica, os mais produtivos na época (MATTOS, et al., 2000). Nesse lapso, desenvolveu-se uma grande polêmica em torno da existência ou não de petróleo no Recôncavo Baiano. ${ }^{9}$

Essa querela envolveu o descobridor do poço que insistentemente buscava provar às autoridades do Governo federal que havia descoberto petróleo na Bahia. Os geólogos estrangeiros, que já haviam trabalhado em grandes companhias de petróleo, tentavam negar a existência do óleo através de relatórios técnicos incorretos, no intuito de desqualificar Oscar Cordeiro. O próprio Governo federal, que buscava solucionar o problema brasileiro do petróleo com uma política nacionalista, continuou postergando todas as iniciativas de exploração de petróleo por particulares.

A exploração do petróleo, como atividade econômica no Recôncavo Baiano, jamais tinha sido praticada. O petróleo não existia em todo o Recôncavo Baiano, mas apenas em uma parte dele, nos terrenos que recobrem a Bacia Sedimentar do Recôncavo, visto que as demais áreas têm o substrato geológico formado por rochas cristalinas nas quais não existe petróleo.

Estruturalmente, os terrenos que fazem parte do Recôncavo Baiano compõem uma fossa tectônica preenchida por rochas sedimentares cretáceas - Bacia Sedimentar do Recôncavo - que, a partir da Baía de Todos os Santos, se estende

\footnotetext{
${ }_{9}^{9}$ Oscar Cordeiro, personagem importante em Salvador, foi fundador e presidente da Bolsa de Valores da Bahia e Sergipe, sediada em Salvador, e empresário local. A maneira como o petróleo foi descoberto por Oscar Cordeiro na localidade de Lobato, no município de Salvador, constitui uma alegoria que Victor (1970), Marinho Jr. (1989) e outros reproduziram em seus livros.
}

Oscar Cordeiro tentou, sem sucesso, desenvolver a mina na esperança de obter algum lucro do negócio, mas o Governo federal obliterou todas as tentativas de continuidade do empreendimento. 
até o Norte do estado, na direção N-NE, cujos depósitos contêm petróleo. Essa fossa tectônica é limitada de ambos os lados, pelas falhas de Salvador e de Maragogipe, ambas de embasamento cristalino - gnaisse.

Os campos de exploração e produção de petróleo e gás natural no Recôncavo Baiano, à medida que iam sendo descobertos tiveram ampla disseminação, em grande medida exatamente na área core das lavouras de cana-de-açúcar.

Segundo Costa Pinto (1958), o início de todo o processo de inserção do CNP no Recôncavo Baiano e suas ações na busca pelo petróleo no subsolo foi marcado por forte rejeição dos fazendeiros, principalmente pelo tipo de trabalho desenvolvido no início. Os trabalhos consistiam no deslocamento de turmas de homens "estranhos", ferramentas e máquinas pelas fazendas transportados em viaturas e que, em vários locais do terreno, abriam buracos em áreas de canaviais e/ou pastos onde explodiam "bananas de dinamite" provocando, dessa maneira, ondas sísmicas que, pela análise técnica, determinava a probabilidade ou não da existência do óleo. Havendo óleo passava-se à sua exploração. Nessa etapa a destruição das benfeitorias que estava na superfície era bem maior que na etapa anterior.

Tudo isso suscitava muitas desavenças entre os fazendeiros e os funcionários do CNP, em decorrência dos estragos provocados durante os trabalhos de prospecção geofísica e da própria atividade de exploração e produção de petróleo e gás natural.

Uma vez iniciadas, as atividades provocavam toda sorte de destruição do que estava instalado sobre o solo: contaminação das águas com o óleo e produtos químicos utilizados na perfuração dos poços; destruição parcial de canaviais, roças e pastos, dentre outras. Sobre isso escreveu Costa Pinto (1958, p. 81-82):

\footnotetext{
De um fazendeiro ouvimos a seguinte interrogação: 'Será que o petróleo só há de dar em canavial novo?' - queixando-se de que a turma responsável pelo trabalho pisava nos brotos da cana recem-nascida e destruía as covas recemplantadas. Derrubada de cercas pelos jipes da geofísica, que circulavam como se elas não existissem, esta, então, era uma das queixas mais freqüentes. De outro fazendeiro ouvimos esta exclamação: 'Deus me livre que haja petróleo em minhas terras!'
}

Esse tipo de reação, comum na época, ocorria muito mais por uma indefinição quanto à possível indenização a ser paga em decorrência dos estragos provocados nos estabelecimentos, e dava a

[...] impressão de que as relações entre a indústria do petróleo e os proprietários e lavradores da agricultura local dependiam, antes de mais nada, do ânimo e do temperamento dos engenheiros responsáveis, pois, na verdade, nenhuma norma 
jurídica regulava o assunto nem se tinha a impressão de existir sôbre o assunto um princípio, ou plano ou sistema a ser impessoalmente obedecido por todos (COSTA PINTO, 1958, p. 91).

Isso revela o tipo de relação, pouco amigável e unilateral, que existia entre a administração regional do CNP, fazendeiros e usineiros. Como não havia um parâmetro formal que determinasse em que condições dar-se-iam as possiveis indenizações dos prejuízos e desapropriações de terras, os usineiros, os fazendeiros e os lavradores, aceitavam, quase sem opção de escolha e descontentes com as ações, as quantias referentes às indenizações e condições de pagamento por parte do CNP. Essas indenizações pagas pelo CNP, pelo que se indica, dependiam do humor dos engenheiros responsáveis e que, até por isso, era financeiramente prejudicial para o próprio órgão.

A inexistência de uma sistemática de trabalho mais racional nas operações desenvolvidas pelo órgão e de parâmetros previamente determinados para cumprir as indenizações referentes às desapropriações, ocupações e estragos feitos nos estabelecimentos rurais, levava a super e/ou subvalorização das quantias a serem pagas. Sobre isso, Costa Pinto (1958) relata o caso da desapropriação imensamente vantajosa para o proprietário de uma fazenda na área canavieira do Recôncavo Baiano: ${ }^{10}$

[...] a antiga usina Colônia, que já com seus fogos apagados foi, apesar disso,
desapropriada pelo CNP por dez milhões de cruzeiros, afigurou-se um desfêcho
desejável para alguns e por eles pleiteado, nas mesmas bases inteiramente des-
proporcionais ao valor dos estabelecimentos, do seu equipamento e das suas
terras (COSTA PINTO, 1958, p. 91).

A reação inicial à exploração do petróleo no Recôncavo Baiano tinha nos proprietários de terras e usineiros locais o seu primeiro embate. Eles reclamavam que além da inutilização das terras, também estavam perdendo os funcionários mais hábeis para o CNP, além do encarecimento da mão-de-obra, pois esse órgão pagava os melhores salários no estado da Bahia. A direção do CNP contra-argumentava negando as acusações, sem maiores implicações para a produção de petróleo em terra, que no Recôncavo Baiano seguia em escala cada vez mais crescente (COSTA PINTO, 1958).

Como as atividades ligadas ao petróleo requeriam uma grande quantidade de força de trabalho imediatamente e com as habilidades necessárias: mecânicos

\footnotetext{
10 Para Mariani (1977, p. 80), tudo que vinha do Governo central era visto como uma sórdida conspiração contra a Bahia. Sobre a desapropriação da usina Colônia, já desativada, anos mais tarde ele declara: "uma delas posta fora de combate pela ocupação manu militari de suas terras pelo Conselho de petróleo, impossibilitando o trabalho rural".
} 
industriais, tratoristas, caldeireiros, soldadores e outros, o CNP recrutava grande parte desses trabalhadores nas usinas de açúcar, principalmente quando da construção e montagem da refinaria de Mataripe.

Em virtude da abundância do petróleo no Recôncavo Baiano, comprovada ano após ano, foi determinado a construção da primeira refinaria estatal de petróleo do país, em 1947, durante o governo do presidente Dutra.

A decisão de implantação da refinaria de petróleo no Recôncavo Baiano em 1947, bem como da construção da rodovia Rio/Bahia em 1949, dentre outras, surgiu no bojo das políticas compensatórias do Governo Dutra para com a Bahia, diante das desvantagens comerciais reclamadas pelas classes dirigentes regionais como bem entendeu Guimarães (1982), mas também, e principalmente, como prenúncio das condições para a futura expansão da economia do centro.

A Refinaria Nacional de Petróleo (RNP), como se chamaria, com capacidade inicial de refino de 2.500 barris/dia (bpd), foi construída numa localidade denominada Mataripe, município de São Francisco do Conde. Os trabalhos de construção da RNP foram iniciados em fins de 1948 e a refinaria inaugurada em setembro de 1950. Posteriormente, com a criação da Petrobras, a RNP passou a chamar-se Refinaria Landulpho Alves (RLAM). ${ }^{11}$ Anteriormente à RLAM, existiam duas pequenas destilarias de petróleo montadas pelo CNP.

A lógica da definição do local para a construção da refinaria teve como pressuposto a teoria clássica da localização industrial, cujo elemento determinante do ponto de custo mínimo foi a fonte de fornecimento de matéria-prima - em suas proximidades, a uma distância de cerca de $6 \mathrm{~km}$, onde se localizava um dos maiores campos de petróleo descoberto pelo CNP em 1941 - que, além de dispor de fonte de água doce para utilização nos processos de destilação, também poderia dispor do menor custo de transporte dos produtos para os mercados, por via marítima, utilizando o transporte marítimo na Baía de Todos os Santos.

A dificuldade de transporte por terra era grande, considerando que naquela época, para se vencer uma distância de $72 \mathrm{~km}$ entre a refinaria e a cidade de Salvador, gastava-se entre três e quatro horas de caminhão e, no período das chuvas, era impraticável fazer esse trajeto. De trem, partindo da localidade de Candeias a $6 \mathrm{~km}$ da refinaria, gastava-se entre 1,5 horas e 2,0 horas até Salvador. O tempo gasto nesses $6 \mathrm{~km}$ poderia chegar a até 4,0 horas durante o período das chuvas, por motivo de atoleiros na estrada ainda sem asfalto. Em decorrência

\footnotetext{
${ }^{11}$ Landulpho Alves foi interventor na Bahia entre 1938 e 1942, depois eleito senador (PTB), destacou-se na defesa do monopólio estatal do petróleo quando dos debates no Congresso Nacional (1951-1953) sobre o Projeto de Lei de criação da Petrobras.
} 
disso, todo o material empregado na construção da refinaria chegava ao local por mar, utilizando-se os saveiros e para os equipamentos de grandes dimensões utilizavam-se rebocadores (JANKE, 1959).

Uma das inserções de efeito mais eficaz do CNP na antiga sociedade organizada em torno da cana-de-açúcar foi a implantação da refinaria de petróleo que, apesar de ainda pequena, deu nova dinâmica à economia e à sociedade locais. Entre as razões estão: o próprio processo de sua construção, que reuniu uma numerosa força de trabalho, fazendo circular uma importante massa monetária referente aos salários e pagamentos diversos; as relações de trabalho estritamente contratuais; o surgimento, ainda que embrionário, de um tipo novo de operário fabril e, também, a emergência de um novo tipo de ação social marcado pela impessoalidade da sistemática de organização do trabalho que se inaugurava na Bahia.

Contudo, a novidade inaugurada pelo CNP também se revelava, até certo ponto, num tipo de relação baseada, não raro, na dominação entre os chefes do órgão e seus subalternos, os próprios operários e entre os primeiros e seus interlocutores externos - fazendeiros, usineiros e lavradores. As relações de mando refletiam a tradição do regime militarizado nos quadros superiores dos órgãos estatais federais da época.

O arbítrio dos chefes do CNP em relação aos fazendeiros, lavradores e usineiros já foi comentado anteriormente. Internamente, os abusos dos chefes em relação aos operários tinham na ideologia da construção da independência petrolífera do Brasil um amortecimento do caráter impositivo do trabalho compulsório à noite e nos fins de semana e não-remunerado para os operários, técnicos e engenheiros que habitavam a vila da refinaria, pois todos os operários, inclusive engenheiros, se obrigavam a estar a postos para os casos de emergências que ocorriam com grande freqüência à noite, não se afastando do local de trabalho - a refinaria - para gozo de férias e visita às famílias, sob a alegação de necessidade do trabalho, como explica Oliveira Jr. (1996).

Diante do exposto, vê-se, até então, que não foi possível surgir um agente hegemônico nas relações entre os agentes sociais analisados, em face de as relações entre eles serem marcadas não raro por coações ou por outros tipos de ações verticais e, portanto, muito distantes de ações tomadas em concerto. Nessas condições, tal como as relações de poder que subsistiam de maneira tênue, o território organizado em torno das demandas dos referidos agentes estava em vias de dissolução.

A estrutura social e produtiva anacrônicas, em vigor no Recôncavo Baiano estava em deterioração e seu processo de transformação pelo que predomina atualmente somente toma corpo a partir dos anos 1960, por meio de ações de 
natureza mais macroeconômicas empreendidas pela Petrobras. A participação da Petrobras e a inter-relação com os seus interlocutores regionais desenvolvida ao longo do tempo foram sendo alteradas e, com isso, novas relações sociais baseadas em acordos passaram a ser privilegiadas.

\section{A organização territorial resultante das relações entre os agentes sociais no antigo Recôncavo Baiano}

Os reflexos de uma economia eminentemente agro-mercantil em decadência projetaram-se no Recôncavo Baiano, reproduzindo um território, por assim dizer, empobrecido e envelhecido, representativo de um passado distante, tornandose o espelho das ações dos agentes que empreendiam os processos econômicos, políticos e sociais na Bahia.

Nesse sentido, as lamentações de Mariani (1977), atribuindo à Revolução de 1930 toda a responsabilidade pela decadência econômica do estado da Bahia, em virtude da retenção de parte dos lucros das reservas cambiais referentes às exportações baianas, e o comércio triangular a que foi submetido o estado da Bahia que se refletia no esforço de exportar para o estrangeiro as mercadorias de natureza agrícola e importar do Sudeste do Brasil as mercadorias industrializadas a preços elevados, para subsidiar o processo de industrialização da região Sudeste do Brasil, constituem tão-somente uma aleivosia, tendo em vista que as condições históricas da participação dos espaços econômicos periféricos na economia nacional já estavam dadas (AZEVEDO, J., 1975).

De outro modo, internamente, as ações dos próprios condutores da economia baiana eram marcadas pela especulação fundiária/imobiliária na cidade do Salvador e com papéis em torno das atividades agro-mercantis, conforme explicaram Oliveira, F. (1987a) e Kraychete Sobrinho (1988), do qual, ele (Mariani) era um dos maiores, senão o mais importante expoente, tanto para operar como para pensar os processos que davam seguimento à continuidade da evolução econômica, de maneira especulativa. Associado a isso, pesava a perda de fração significativa da influência política a que os grupos baianos estavam acostumados nos postos-chave da república, com a nova ordem nacional implantada no Brasil a partir de 1930 (GUIMARÃES, 1982). A nova ordem nacional esboça-se no programa objetivo de unificação e de centralização do mercado nacional, com centro em São Paulo e na industrialização. 
Essa incrivel forma engenhosa das classes dirigentes baianas seguir criando fortunas, sem um fundamento que provesse sua manutenção regular, apostando apenas na generosidade da natureza, na sagacidade de um ou outro comerciante e/ou banqueiro importante, ancorado no amparo fiscal e financeiro do Estado, dependente das contingências dos mercados estrangeiros, e secularizada na manutenção de uma horda de serviçais desvalidos, já estava esgotada no crepúsculo dos anos 1940. Era disso que Mariani e o governador Mangabeira queixavam-se, mas não se dignavam a assumir.

No estado da Bahia subsistiam, assim, zonas de atividades agropecuárias e agroindustriais: açúcar e fumo (Recôncavo Baiano), cacau (Sul da Bahia), sisal e gado (Sertão), pouco prósperas, autárquicas e controladas pelos financistas e pelos grandes comerciantes sediados na cidade do Salvador.

As ações implementadas pelos senhores de engenho e, posteriormente, pelos usineiros fizeram erigir secularmente a grande lavoura de cana. Com isso, todas as demais atividades econômicas existentes desempenhavam apenas funções acessórias. Assim, a produção de alimentos e a criação de animais para corte e leite ocorriam de maneira marginal, em pequena escala, seja nas próprias fazendas de cana-de-açúcar, voltadas para o autoconsumo, seja nas fazendas da zona do fumo, onde a lida com a produção de alimentos era, muitas vezes, feita com o auxílio do mutirão, pois não sobravam recursos aos lavradores para pagar o trabalho de outrem. Contudo, o Recôncavo Baiano como um todo gerava um excedente de alimentos que se comercializava na cidade do Salvador e nas feiraslivres locais, o que era bastante comum.

Com o aprofundamento da crise do fumo e do açúcar ainda no período em foco, algumas áreas no Recôncavo Baiano foram marginalizadas e, como alternativa de viabilidade econômica e funcional, passaram a ser utilizados para produzir alimentos e criar animais para o abastecimento de grande parte da população da cidade do Salvador. A parte excedente era comercializada nas feiras-livres dos demais municípios do Recôncavo Baiano e de suas adjacências.

No Recôncavo Baiano, as áreas que forneciam alimentos de maneira relativamente sistemática eram formadas pelos municípios que também produziam fumo - Nazaré, Maragogipe, Aratuípe, São Felipe entre outros. Dessa parte provinham especialmente a farinha de mandioca (Nazaré), frutas, legumes, verduras pequenos animais, crustáceos, azeite de dendê e ainda utensílios de cerâmica que eram transportados por animais de carga, saveiros, trem e caminhões (COSTA PINTO, 1958; SANTOS, M., 1959a). 
No outro extremo, consolidaram-se também na função de produção de alimentos os municípios do Recôncavo Norte - Catu, Pojuca, Mata de São João e outros - de onde saiam também a farinha de mandioca, frutas, legumes, verduras, pequenos animais e, em especial, carne e leite, em razão da tradição de criação de gado desde o início do período colonial, com o fidalgo Garcia D'Ávila. Dessa parte, os alimentos eram transportados de trem até a cidade do Salvador.

Como na área core da cana-de-açúcar e do fumo, também no Recôncavo Norte, nas fazendas de criação de gado, o paternalismo era o traço comum das relações sociais e de produção entre o fazendeiro e os vaqueiros. A lealdade aos compromissos firmados entre ambos determinava as relações entre os "compadres" (BAHIA, [1972?]). ${ }^{12}$

A atração e fixação de uma população numerosa proporcionada pelas usinas de açúcar, lavouras de cana, manufaturas de fumo, lavouras de fumo e demais atividades econômicas urbanas e rurais, fizeram do Recôncavo Baiano, em 1950, a região da Bahia de maior densidade urbana, com apenas $19 \%$ da população total do estado, concentrando, entretanto, mais de $43,6 \%$ da população urbana total do estado, ou seja, 545.006 habitantes, dos quais 493.787 (91\%) residiam nas sedes dos municípios (Tabela 7).

Cumpre ressaltar que desse contingente demográfico a cidade do Salvador se destaca concentrando $71 \%$ da população urbana total desta região, isso como resultado da imigração de população proveniente, em grande parte do Recôncavo Baiano. Contudo, ao se considerar a proximidade relativa entre os núcleos urbanos: cidades, vilas e povoados da específica rede urbana no interior de uma economia agro-exportadora em declínio pode-se concluir como Santos, M. (1959a, p. 7):

O Recôncavo é, por excelência, a região de cidades da Bahia.

A natureza da sua economia de exportação (Recôncavo açucareiro e fumageiro) condicionou a formação de numerosos núcleos urbanos e mêsmo nas áreas de subsistência (Recôncavo Sul) pôde se criar uma vida urbana, em virtude da proximidade de Salvador.

\footnotetext{
${ }^{12}$ Nas relações entre fazendeiros e funcionários é comum ambos se tornarem compadres. Esses laços afetivos ocorrem entre os empregados de maior confiança e o fazendeiro. O significado sociológico dessa relação é complexo, mas objetivamente se traduz em vantagens para ambos: de um lado, o fazendeiro beneficia-se da lealdade do compadre no trato com os seus bens, sem arcar com os custos próprios de uma relação contratual; por outro lado, o empregado passa a gozar dos benefícios que envolvem o prestígio do compadre patrão e outras vantagens não pecuniárias.
} 
Tabela 7 - Recôncavo Baiano: população total e urbana, por municípios - 1950

\begin{tabular}{|c|c|c|c|c|}
\hline \multirow{4}{*}{ Municípios } & \multicolumn{4}{|c|}{ População } \\
\hline & \multirow{3}{*}{$\begin{array}{c}\text { Total } \\
\text { Absoluto }\end{array}$} & \multicolumn{3}{|c|}{ Urbana } \\
\hline & & \multirow{2}{*}{ Absoluto a) } & \multicolumn{2}{|c|}{ Na sede } \\
\hline & & & Absoluto b) & $\% \mathrm{~b} / \mathrm{a}$ \\
\hline Salvador & 417.235 & 386.522 & 386.522 & 100,0 \\
\hline Santo Amaro & 85.739 & 29.931 & 12.258 & 41,0 \\
\hline Maragogipe & 36.868 & 15.088 & 9.744 & 64,6 \\
\hline Cachoeira & 26.816 & 12.816 & 10.825 & 84,5 \\
\hline Nazaré & 21.105 & 12.541 & 11.205 & 89,3 \\
\hline Santo Antônio de Jesus & 29.668 & 11.839 & 11.417 & 96,4 \\
\hline Cruz das Almas & 32.276 & 8.912 & 6.758 & 75,8 \\
\hline Muritiba & 31.605 & 8.848 & 7.452 & 84,2 \\
\hline Itaparica & 21.433 & 8.634 & 2.603 & 30,1 \\
\hline Mata de São João & 17.651 & 7.540 & 4.766 & 63,2 \\
\hline São Félix & 14.801 & 5.987 & 5.872 & 98,1 \\
\hline São Gonçalo dos Campos & 30.830 & 5.596 & 3.771 & 67,4 \\
\hline São Sebastião do Passé & 21.135 & 5.079 & 2.544 & 50,1 \\
\hline Camaçari & 13.800 & 4.440 & 2.715 & 61,1 \\
\hline Catu & 16.437 & 4.140 & 3.558 & 86,0 \\
\hline Jaguaripe & 10.403 & 2.978 & 1.006 & 33,8 \\
\hline Pojuca & 6.911 & 2.694 & 2.534 & 94,1 \\
\hline Conceição do Almeida & 25.407 & 2.539 & 2.026 & 79,8 \\
\hline São Francisco do Conde & 11.077 & 2.504 & 1.453 & 58,0 \\
\hline Aratuípe & 6.351 & 2.291 & 1.432 & 62,5 \\
\hline Conceição de Feira & 10.532 & 2.216 & 2.246 & 100,0 \\
\hline São Felipe & 25.343 & 1.811 & 1.080 & 58,7 \\
\hline Total do Recôncavo & 916.723 & 493.787 & 493.787 & 90,6 \\
\hline Total da Bahia s/ o Recôncavo & 4.834 .575 & 1.250 .507 & 947.447 & 75,8 \\
\hline
\end{tabular}

FONTE; Organizada por Brito (2004), com base em IBGE (1955).

A cidade do Salvador, concentrando $71 \%$ da população urbana do Recôncavo Baiano desempenhava a função de "cabeça de ponte" que drenava grande parte da riqueza (recursos, bens, dinheiro, população) de sua hinterlândia imediata, apoiando-se nas diferentes modalidades de transporte de carga e passageiros, ou seja, navios e outros tipos de embarcações, trem, caminhões e ônibus, tal como descreveu Santos, M. (1959a), ao tratar da função dos transportes na rede urbana do Recôncavo Baiano.

Exceto o município de Salvador que possuía quase 400 mil habitantes residindo na área urbana, em 1950, a referida rede urbana era composta de pequenas cidades, consideradas aqui apenas a sede do município. Dessas cidades, quatro possu- 
íam população entre 10.000 e menos de 15.000 habitantes; quatro entre 5.000 e 10.000 habitantes; as demais (13), todas com menos de 5.000 habitantes. Entretanto, havia muitas vilas e povoados que reuniam uma numerosa população urbana. Várias dessas aglomerações tinham mais de 1.000 habitantes, a exemplo do município de Santo Amaro que se destaca com quatorze desses núcleos, os quais desempenhavam algumas funções urbanas centrais, por exemplo, serviços de saúde, educação, comunicação e abastecimento, dentre outras.

Esses embriões urbanos, na maioria das vezes eram vilas operárias, tinham um peso relativo significativo e desempenhavam uma importante função nas atividades agroindustriais, sobretudo na zona açucareira, mas não eram menos importantes na zona do fumo. Tais unidades urbanas tinham, geralmente, como elemento centralizador a usina de açúcar ou a fábrica de charutos. As vilas operárias mantidas pelas usinas de açúcar tinham sua devida importância, contribuindo, sobremaneira, para fixar uma numerosa população próximo à fábrica.

O município de Santo Amaro, com 10 usinas de açúcar e uma destilaria de álcool, apresentava maior destaque, pelo fato de cada unidade industrial manter sua própria vila operária. Para uma população urbana de mais de 17.000 habitantes, residindo fora da sede do município, é possível que grande parte dessa população habitasse as vilas operárias, considerando que esses empreendimentos, geralmente empregavam cerca de mais de 1.000 operários diretamente na fabricação de açúcar, e em torno de 5.000 lavradores nas lavouras de cana. Conforme Muricy (1946, p. 1) "Os trabalhadores de uma usina de açúcar são, geralmente, em número inferior aos trabalhadores dos campos da mesma usina. A proporção é de 1 empregado da usina para 5 do campo."

A Tabela 7 oferece, ainda, uma referência da quantidade de habitantes acostumados à vida urbana, embora simples, organizada no interior das vilas operárias das usinas de açúcar, que reuniam maior quantidade de pessoas para os trabaIhos nas fábricas e nas fazendas de cana. Na zona do fumo, as vilas operárias das fábricas de charutos localizavam-se nas cidades e por isso sua importância era menor.

As vilas operárias eram dotadas de infraestrutura urbana básica: arruamento, sarjeta, abastecimento de água, eletricidade, saneamento, praça pública. Além disso, mantinham serviços para atender às demandas mais urgentes de seus habitantes como, por exemplo, escola primária, posto médico, armazém, templo religioso, segurança etc., devido às grandes distâncias e dificuldade de transporte da fábrica até as aglomerações urbanas nas sedes dos municípios e distritos.

No plano geral, além da infraestrutura urbana, dos serviços disponíveis e da contribuição como elemento civilizatório, para os empresários, as vilas operárias cumpriam também o seu mais importante e imediato papel, o ideológico. Tratando a esse respeito com exemplos de usinas de açúcar em Pernambuco, Lopes (1978) afirma: 
Além disso, as concessões extramonetárias recebidas pelos operários, que giram em torno da casa da usina, trazem importantes repercussões sobre a mobilidade dos operários no mercado de trabalho. Pois não há dúvida de que qualquer ameaça de demissão ou qualquer projeto de procurar um novo emprego esbarram com dois obstáculos que se completam e que praticamente imobilizam o operário: além de se ver na situação de desempregado ao ser demitido ou demitir-se para procurar emprego, o operário vê-se também simultaneamente na condição de despejado. Com efeito, colocar-se na posição de quem procura emprego em nova usina, com a superpopulação existente nas usinas, de fato equivale a engrossar as fileiras dos desempregados, com o agravante de ter que providenciar, nas piores condições, um teto para sua família. É essa instabilidade que se reflete direta e simultaneamente na esfera do trabalho e na esfera doméstica dos operários, principalmente os residentes na vila da usina, que sustenta o fetichismo do salário dos profissionistas e sua tolerância com as enormes jornadas de trabalho a que são submetidos. Dependentes da administração quanto às condições materiais diretas de existência de sua própria moradia, os operários têm que pensar duas vezes ao verem negadas pelos empregados suas reivindicações mínimas (LOPES, 1978, p. 182, grifos nossos)..$^{13}$

\section{É claro que as vilas operárias eram projetadas para oferecer aos seus habitan-} tes as condições mais elementares e suficientes de habitabilidade com fim utilitarista para o qual foram concebidas. Dessa maneira, há nos princípios determinados pelos patrões uma seletividade no padrão de construção das habitações, na localização em relação às amenidades sociais e naturais e, portanto, também uma seletividade na ordem de ocupação para os futuros usuários. Nesse sentido, Lopes observa que,

Ao emprego fixo do operário casado está associada a possibilidade de este operário obter o usufruto de uma casa da usina, nos arruados destinados às famílias operárias que circundam a usina, de forma tal que esse lugar seja homólogo ao lugar dos operários na estrutura social da usina. Com efeito, contrastando com as casas dos empregados, espaçosas e confortáveis, de classe média abastada, as pequenas casas dos operários, uniformes e coladas umas às outras, situam-se nos lugares mais poluídos e insalubres das vizinhanças da usina, convivendo com os efeitos dos resíduos do processo de produção do açúcar - a 'borra' do caldo, seu mau cheiro e seus insetos; a fuligem proveniente do 'bueiro', a chaminé da usina cuja fumaça, levada pela direção do vento, inunda a casa dos operários; barulho intermitente dos trens passando pela estrada de ferro que eventualmente passa exatamente colada a fileiras de casas operárias (LOPES, 1978, p. 175-176, grifos do autor).

\footnotetext{
${ }^{13} \mathrm{O}$ termo empregados é utilizado pelo autor no sentido de distinguir os operários, dos gerentes e chefes das usinas. A denominação é atribuída pelos operários entrevistados pelo autor, com a finalidade de distinguir os proprietários dos funcionários. Os profissionistas se distinguem dos artistas na usina por lidarem diretamente com a produção, enquanto os artistas lidam com a manutenção dos equipamentos.
} 


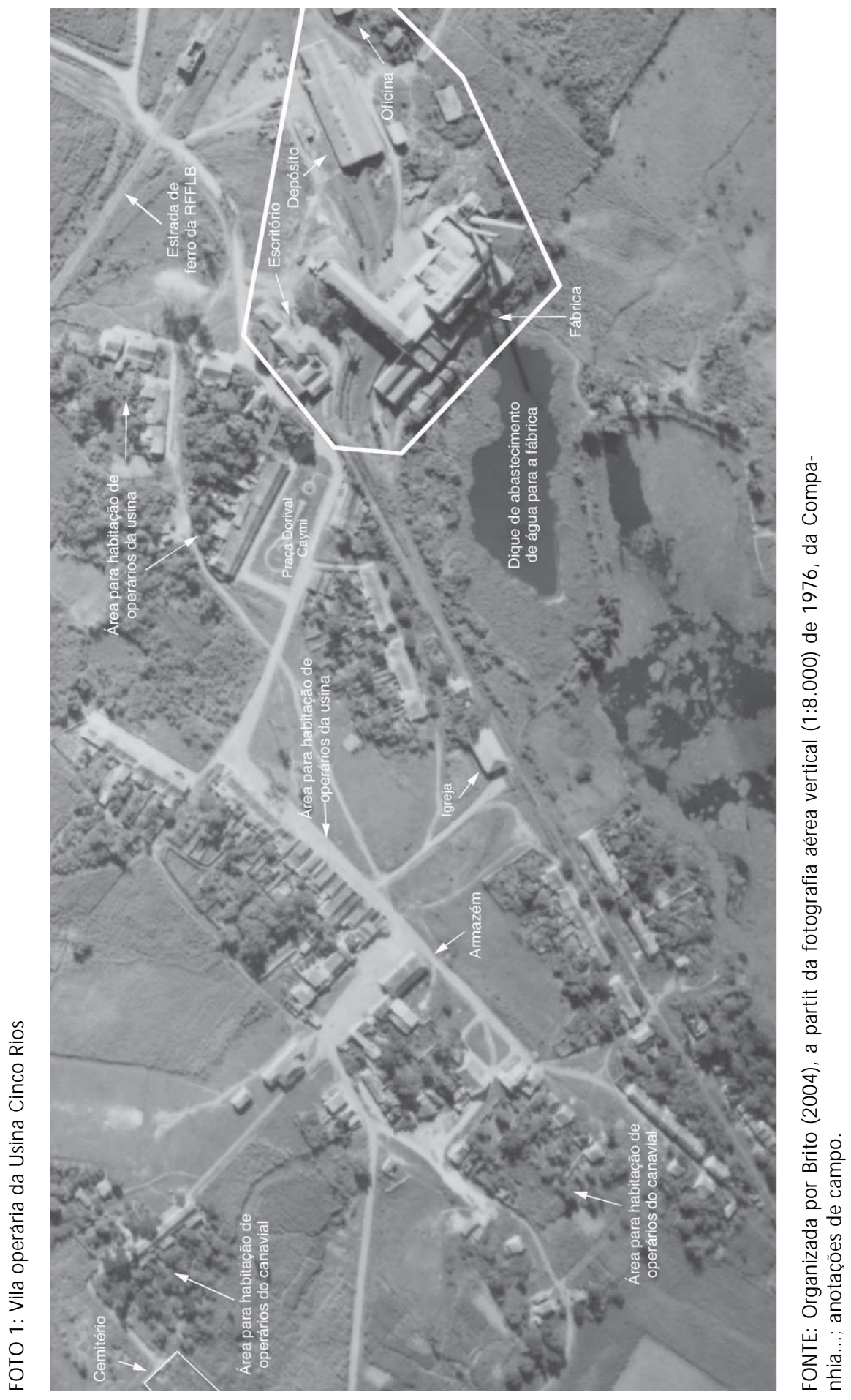


Esse modelo de vila operária de usina de açúcar descrito por Lopes (1978) em Pernambuco também se repetia no Recôncavo Baiano. O exemplo da Usina Cinco Rios, em São Sebastião do Passé, é ilustrativo (Foto 1).

Em fins dos anos 1940, a usina Cinco Rios empregava cerca de 1.000 funcionários, entre operários e técnicos envolvidos com as atividades de escritório, produção, manutenção e transporte e cerca de mais 2.000 funcionários que trabaIhavam na lavoura. A usina localiza-se acerca de $30 \mathrm{~km}$ da cidade de São Francisco do Conde e a aproximadamente $18 \mathrm{~km}$ da cidade de São Sebastião do Passé, as cidades mais próximas.

A usina encerrou suas atividades em 1986, seus canaviais foram liquidados, transformados em fazendas de pastagem para gado. No entanto, a vila operária, Maracangalha, como é conhecida, segue com os antigos habitantes, ex-funcionários da usina. Em fins dos anos 1950, a vila possuía cerca de 400 casas habitadas por mais de 1.100 pessoas; dispunha de arruamento com paralelepípedo (sete ruas), saneamento, abastecimento de água potável, energia elétrica, praça pública e demais equipamentos públicos, além de armazém, posto médico, escola primária, templo católico e um cinema, tudo mantido pela usina, subsidiado pelo IAA. Atualmente, a vila é administrada pela Prefeitura Municipal de São Sebastião do Passé.

Também na vila operária da Usina Cinco Rios, a ocupação das habitações seguia uma lógica fundamentada na posição que os funcionários da usina ocupavam na unidade produtiva (fábrica/fazendas). Dentre as condições para a utilização das casas na vila considerava-se se os funcionários trabalhavam na fábrica ou no campo. Os operários que ocupavam posição de destaque na usina ocupavam as melhores casas e melhor localizadas, em torno da praça e também na rua em frente à usina. À medida que a distância da casa em relação à usina aumentava, o status sócio-profissional do trabalhador diminuía junto com a qualidade e o tamanho da habitação.

As casas da Vila Cinco Rios eram relativamente modestas e apresentavam padrão de construção variado. Aproximadamente 20 casas tinham melhor padrão construtivo, com área construída de até a $114 \mathrm{~m}^{2}(9,5 \mathrm{~m} \times 12,0 \mathrm{~m})$, varanda, quatro quartos, duas salas um banheiro, uma cozinha e quintal. Essas casas se localizavam nas partes menos sujeitas aos odores e à fuligem provenientes do funcionamento da fábrica: na praça, na rua em frente à usina, e eram habitadas por famílias de funcionários bem posicionados na usina, chefes de turma, cozinhadores, administradores, químicos e outros técnicos (Foto 2).

Na posição extrema, estavam os operários de campo, os que tratavam do canavial e cortavam a cana. Seguindo a hierarquia da divisão técnica do trabalho, a esses operários era atribuído pouco prestígio e, como tal, ocupavam as casas mais humildes, situ- 
adas na periferia da vila. Essas casas eram pequenas e dispostas em grupos de unidades geminadas e enfileiradas, com área de menos de $60 \mathrm{~m}^{2}(4 \mathrm{~m}$ e/ou $6 \mathrm{~m} \times 10 \mathrm{~m})$. Internamente, possuíam uma sala, um ou dois quartos, uma cozinha e o assoalho feito à base de tijolos de barro; externamente as edificações tinham fachada simples e contínua, interrompida por uma seqüência de portas e janelas; ao fundo, um pequeno quintal cercado, seguido dos canaviais da usina (Foto 3).

FOTO 2 - Habitação dos técnicos da Usina Cinco Rios

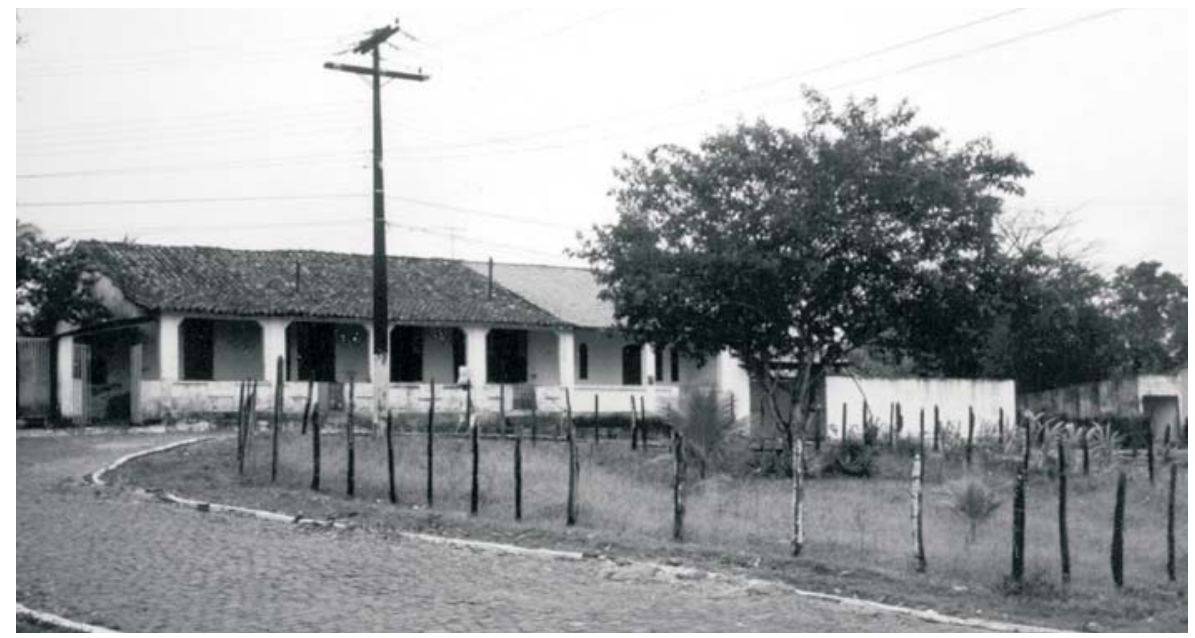

FONTE: Pesquisa de campo do autor.

FOTO 3 - Habitação dos operários de campo da Usina Cinco Rios

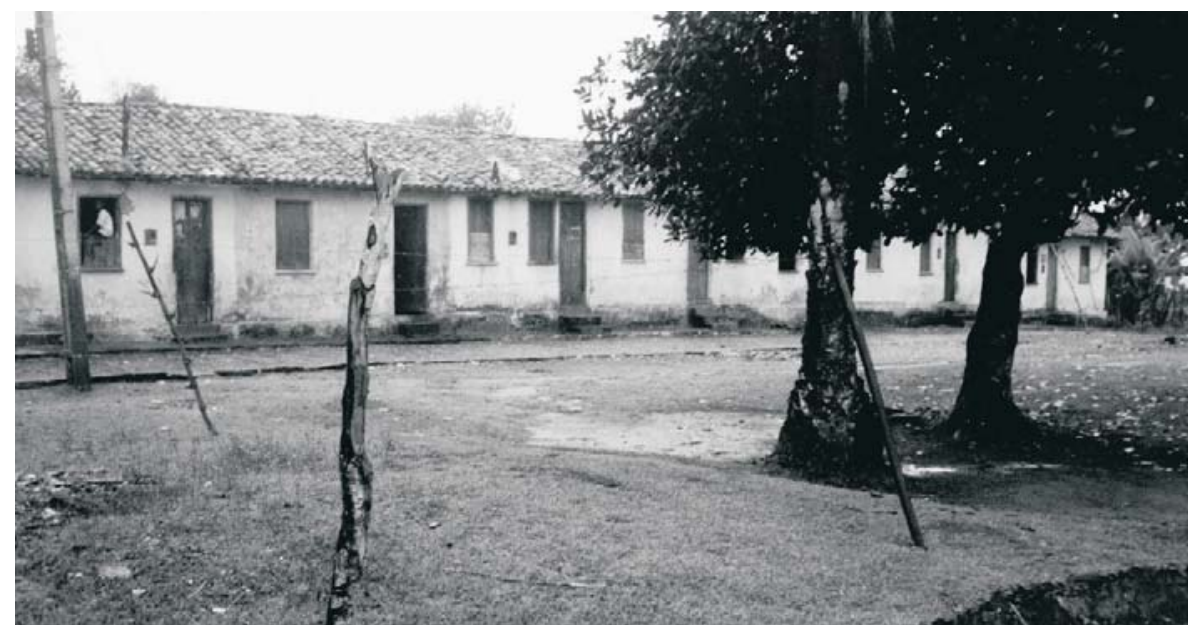

FONTE: Pesquisa de campo do autor. 
Em Maracangalha a maioria das casas situa-se na posição intermediária entre as mais humildes e as melhores.

A vila operária da Usina Cinco Rios é assim, um dos elementos que compõe a paisagem urbana do Recôncavo canavieiro, mas nem todas as vilas operárias eram tão bem organizadas e tampouco dispunham das condições que a referida vila oferecia a seus habitantes, em algumas delas as habitações e os serviços eram muito precários.

\section{A rede urbana do Recôncavo Baiano nos anos 1950}

Apesar da concentração de cidades, vilas e povoados, e da quantidade de população urbana relativamente grande, no Recôncavo Baiano, em meio a uma economia agromercantil em declínio e a um grau elevado de pobreza da população, não aflorava o fenômeno urbano em si, como um modo de vida, sugerido por Lefebvre (1991).

Em razão de as usinas de açúcar e fábricas de charutos serem auto-suficientes, tais empreendimentos satisfaziam, senão todas, grande parte de suas demandas na própria unidade de produção e o que lá não era encontrado, adquiria-se na cidade do Salvador, ou seja, pouca coisa era produzida e comercializada nas cidades, implicando um fator de inibição do desenvolvimento urbano no Recôncavo Baiano.

Contra o desenvolvimento de um modo de vida eminentemente urbano pesava ainda o fato de a economia do açúcar e do fumo estar em ritmo de amortecimento, uma mais rápida que a outra. Isso associado à escassa monetarização da economia local, seja pelos baixíssimos salários recebidos pelos trabalhadores, seja pela circulação mínima de dinheiro (o vale, um pedaço de papel com a assinatura do patrão era a principal moeda em uso na época) contribuía sobremaneira para inibir outras formas de consumo de mercadorias, serviços e câmbio cultural que não aqueles de sempre, oferecidos naqueles núcleos urbanos.

Nessas circunstâncias, a cidade do Salvador, como uma arena organizada pelos principais agentes sociais, funcionava mais como um "ralo drenando para si" grande parte da riqueza gerada no Recôncavo Baiano, influenciando no desenvolvimento urbano de sua região imediata, através de contatos mais diretos com parte da população de todas as cidades (fornecimento de mercadorias industrializadas e serviços diversos e aquisição de alimentos e mercadorias de origem primária). Esse tipo de relação, quando não impedia, dificultava um maior nível de interação espacial entre as cidades do Recôncavo Baiano, dados os tipos de relações funcionais que as uniam - entreposto comercial de mercadorias de base predominantemente agrícola para Salvador e mercadorias industrializadas adquiridas por essa última, para distribuição em sua hinterlândia. 
O dinamismo entre as cidades do Recôncavo Baiano era limitado também pela inexistência de grupos sociais numerosos com potencial e hábitos de consumo variados, pois a reprodução social da maioria da população se dava ao nível da pobreza e, além disso, as famílias importantes das cidades e os grandes comerciantes, os industriais e os usineiros residiam em Salvador.

$\mathrm{Na}$ cidade do Salvador, dentre outras funções urbanas, eram exercidas as de gestão e de acumulação de capital vinculadas às atividades agromercantis, enquanto que as demais cidades da rede urbana do Recôncavo Baiano desempenhavam as funções de produção e coleta de mercadorias para o comércio exterior e inter-regional e também de consumo de mercadorias e serviços importados.

A vida urbana e a funcionalidade dos núcleos urbanos no Recôncavo Baiano eram pouco desenvolvidas, mas, dos 21 núcleos urbanos - excluindo-se a cidade do Salvador, que ocupava a posição de metrópole regional de uma hinterland eminentemente agrária e em declínio econômico - cinco deles ocupavam posição relativamente importante como centros de segunda ordem; quatro ocupavam posições de terceira ordem; seis se distribuíam entre centros de quarta ordem; cinco desempenhavam funções de quinta ordem; e um, ocupava o último nível da hierarquia funcional urbana como mostra a Figura 3.

Além dos serviços próprios da administração pública local, essas cidades eram dotadas de funções urbanas centrais, segundo sua respectiva hierarquia, desde o nível de $1^{\text {a }}$ ordem, que oferecia uma gama maior e mais complexa de bens e serviços à população sob sua área de influência, até os de ordem hierárquica inferior, menos complexos e mais limitados quanto à sua influência espacial. Os serviços mais raros eram os de alfândega e de bolsa de valores que eram oferecidos somente na cidade do Salvador, em seguida vinham os serviços de ensino superior oferecidos na capital e em Cruz das Almas. Os serviços mais banais eram os de cartório, que existia em todas as cidades, agência de correios e posto médico, ambos eram oferecidos em quase todas as cidades.

Na periferia do Recôncavo Baiano localizam-se as cidades de Feira de Santana e Alagoinhas, as quais, à época, desempenhavam papel preponderante na rede urbana baiana, e sua área de influência no Recôncavo Baiano era substantiva, pelo papel complementar ao da cidade do Salvador. Santos, M. (1959a) classifica as referidas cidades como Capital Regional e Centro Sub-regional respectivamente.

Em seu estudo sobre a rede urbana do Recôncavo Baiano, Santos, M. (1959a) elaborou a classificação dos centros urbanos considerando a proporção entre a população urbana total e a população ocupada no setor de comércio e de prestação de serviços de cada município.

Acredita-se que a realidade do fenômeno urbano no Recôncavo Baiano era bem mais complexa e a classificação funcional dos núcleos urbanos que se sugere constitui apenas uma aproximação possivel dessa realidade, com as limitações inerentes às próprias informações históricas. 


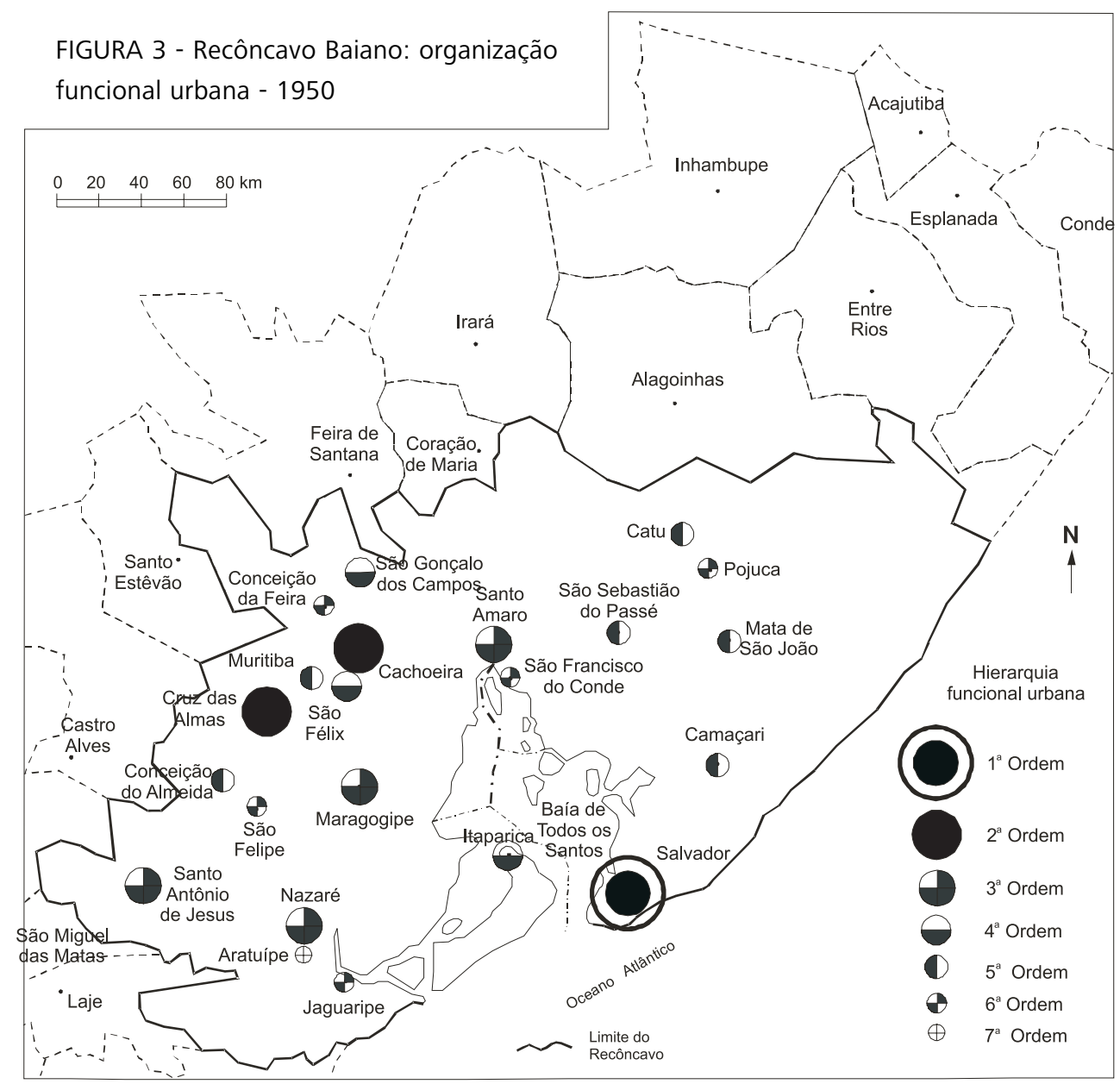

FONTE: Organizado por Brito (2004), com base em IBGE (1958, 1956, 1955).

Como toda classificação dessa natureza, a utilizada nesse estudo também se fundamenta na teoria das localidades centrais de Walter Christaller. Entende-se que a hierarquia das cidades numa rede urbana não surge como um fato dado, mas das condições de como o capitalismo se reproduz e, por conseguinte, como o mesmo em seu processo de reprodução produz o território em questão.

Para essa classificação foram tomadas apenas as sedes dos municípios, porque as vilas e povoados apesar de serem elementos urbanos, porém, eram muito limitados no que se refere à oferta de bens e serviços à população externa e considerando também que a população brasileira nos anos 1950 ainda estava no processo de transição do rural para o urbano. E o fato urbano ainda não apresentava maior complexidade. Cumpre destacar que as vilas anexas às usinas de açúcar serviam 
apenas à população local devido o seu caráter de "fechamento" em relação à população exterior e também pela distância e dificuldade de transporte para outras cidades e vilas.

No sentido de estabelecer a classificação hierárquica dos núcleos urbanos em tela foi feita uma matriz em que aparecem nas linhas as cidades e nas colunas as funções urbanas centrais de maior destaque. Inicialmente, segundo as noções de complexidade e raridade foram definidas as variáveis mais relevantes e indicadoras da centralidade urbana ligadas ao comércio de mercadorias e serviços, administração de serviços públicos e ao transporte, conforme sugerem Christaller, (1993) apud Silva; S.; Souza, J. (1991) e Duarte (1974). Em seguida levantou-se as informações sistematizadas pelo IBGE, publicadas na Enciclopédia dos Municípios Brasileiros, de 1958 e nos Censos Econômico e Demográfico da Bahia, de 1950.

Utilizando-se a planilha do Microsoft Excel criou-se uma matriz, na qual colocouse os nomes das cidades na primeira coluna e na primeira linha as funções urbanas centrais pesquisadas para 1950 (APÊNDICE A). Para cada cidade registrou-se com o número 1 a existência da informação, e com número 0 a sua inexistência, nas respectivas células da matriz desprezando-se a respectiva quantidade para se medir os pesos dos atributos no conjunto da rede urbana.

Tabela 8 - Recôncavo Baiano: hierarquia da rede urbana segundo as funções centrais - 1950

\begin{tabular}{|c|c|c|c|c|}
\hline $\begin{array}{l}\text { Nível } \\
\text { das } \\
\text { cidades }\end{array}$ & $\begin{array}{l}\text { Número } \\
\text { de } \\
\text { cidades }\end{array}$ & Cidades & $\begin{array}{c}\text { Média das } \\
\text { funções } \\
\text { centrais } \\
\text { ponderadas }\end{array}$ & $\begin{array}{l}\text { Média das } \\
\text { funções } \\
\text { centrais } \\
\text { absolutas }\end{array}$ \\
\hline 1 & 1 & Salvador & 95,9 & 23,0 \\
\hline 2 & 2 & Cruz das Almas, Cachoeira. & 42,6 & 19,5 \\
\hline 3 & 4 & $\begin{array}{l}\text { Santo Amaro, Nazaré, Maragogipe, Santo } \\
\text { Antônio de Jesus. }\end{array}$ & 33,6 & 18,0 \\
\hline 4 & 3 & $\begin{array}{l}\text { São Gonçalo dos Campos, São Félix, } \\
\text { Itaparica. }\end{array}$ & 22,7 & 14,3 \\
\hline 5 & 6 & $\begin{array}{l}\text { Camaçari, Mata de São João, Catu, Muritiba, } \\
\text { São Sebastião do Passé, Conceição do } \\
\text { Almeida. }\end{array}$ & 13,1 & 10,0 \\
\hline 6 & 5 & $\begin{array}{l}\text { Conceição de Feira, São Francisco do Conde, } \\
\text { São Felipe, Jaguaripe, Pojuca. }\end{array}$ & 8,6 & 7,2 \\
\hline 7 & 1 & Aratuípe & 1,0 & 1,0 \\
\hline
\end{tabular}

FONTE: Pesquisa do autor. 
Após a determinação dos pesos de cada uma das funções urbanas, que se obtém dividindo-se a quantidade de cada atributo de centralidade existente no sistema de cidades pelo número de cidades, foi feita a classificação dos núcleos urbanos, agrupando-os de acordo com o grau de homogeneidade intra e intergrupo, resultante da aplicação do cálculo do coeficiente de variação entre os pesos agrupados cujo resultado é mostrado na Tabela 8.

Historicamente organizada em função da coleta de mercadorias do interior para o porto de Salvador e daí para o exterior, a rede urbana do Recôncavo Baiano, ao longo dos anos 1940 tinha-se diferenciado e aumentado um pouco o seu nível de complexidade, sem, contudo, ter atingido, nessa época, a condição de rede urbana complexa e tampouco apresentava condições objetivas para chegar à tal condição, em decorrência do estágio declinante da economia baiana como um todo, em especial no Recôncavo Baiano.

À época, na rede urbana do Recôncavo Baiano, a cidade do Salvador ocupava a posição de metrópole regional, dispondo de todas as funções urbanas centrais pesquisadas. Esse núcleo urbano também era o mais populoso do estado da Bahia, possuía quase 400 mil pessoas. O segundo mais importante núcleo urbano do Recôncavo Baiano era, de longe, Cruz das Almas (6.758 habitantes), seguida de Cachoeira (10.825 habitantes), Santo Amaro (12.258 habitantes), Nazaré (11.205 habitantes) e Maragogipe (9.744 habitantes), nessa ordem, com os dois primeiros ocupando a segunda e os seguintes a terceira posição na hierarquia funcional, desempenhando o papel de centros de zona. Essas cidades possuíam entre 18 e 20 funções centrais, das 23 funções urbanas pesquisadas, entre as quais, se destacam: agências bancárias, agências de correios e telégrafos e postos telefônicos interurbanos, que para época acredita-se serem essenciais ao funcionamento da economia sub-regional e para a articulação entre as escalas local/ regional/nacional ou até mesmo internacional.

Os referidos núcleos urbanos também ofereciam serviços de saúde, judiciário, educacional e de diversão à população local e às das demais localidades situadas sob sua área de influência urbana.

O destaque dessas cidades deve-se à sua posição de entreposto comercial estruturado à beira-rio e dentro de baías, desde o período colonial. O caso especial é o de Cruz das Almas (que não está junto de rio ou mar), a única do interior baiano a sediar uma instituição de ensino superior (Escola de Agronomia da Bahia), além de um instituto nacional de pesquisas agrárias (Instituto Agronômico do Leste) e o órgão estadual de fomento ao desenvolvimento da cultura do fumo (Instituto Baiano do Fumo). O município era o maior produtor de fumo da Bahia.

Em fins dos anos 1940 a cidade de Nazaré, com um porto fluviomarinho, era o ponto final da estrada de ferro de mesmo nome, que por meio de uma extensão de 30,8km construída em 1941, se conectava à localidade de São Roque, na 
foz do rio Paraguaçu, na Baía de Todos os Santos (ZORZO, 2001), de onde as mercadorias seguiam em embarcações até a capital, e de onde recebia as mercadorias industrializadas. Essa estrada de ferro ligava ao porto várias cidades na parte Oeste do Recôncavo Baiano, a exemplo de Santo Antônio de Jesus, e se estendia até o município de Jequié, que compunha uma outra região de onde era coletada e transportada a maior parte de uma gama variada de mercadorias: fumo, alimentos, açúcar, café, cacau, utensílios de cerâmica e outros.

A condição de entreposto comercial importante, estruturado na cidade de Nazaré, induziu a instalação cumulativamente de um conjunto de infraestrutura de apoio às demandas dos negociantes e da população em geral, como por exemplo, agências bancárias, fórum, hospitais, hotéis, colégios de ensino médio, serviços de profissionais liberais, órgão públicos estaduais e federais, já que os seus congêneres municipais já faziam parte da estrutura administrativa dos municípios.

Por não dispor de elementos estatísticos para medir a área de influência das cidades durante o período em apreço, admite-se que o deslocamento de uma população de uma dada localidade em busca do atendimento às suas necessidades dá-se sempre pela tendência à utilização de vias de acesso e meios de transporte que minimizem a contabilidade final dos custos de transporte. No Recôncavo Baiano de fins da década de 1940, os meios de transporte mais utilizados eram o trem, o caminhão que estava no início de sua difusão, e as tropas de burros, além da navegação na Baía de Todos os Santos e nos rios navegáveis. A Figura 4 oferece uma idéia aproximada da infraestrutura de transporte terrestre disponível no Recôncavo Baiano e adjacências na década de 1960.

Para a cidade de Nazaré pode-se admitir que o seu papel regional se estendia às cidades e às localidades situadas em seu entorno imediato: Aratuípe, Itaparica, Jaguaripe, Santo Antônio de Jesus e São Felipe, e também mais distantes, conectadas principalmente pela estrada de ferro e complementada pela navegação de cabotagem na Baía de Todos os Santos.

A cidade de Cachoeira também dispunha de um porto fluviomarinho, conectado a uma estrada de ferro - Central da Bahia - que ligava a cidade do Salvador à região Sudeste do Brasil. De Cachoeira partia um ramal para a cidade de Feira de Santana; ao longo do trajeto a ferrovia colocava em comunicação várias localidades e cidades próximas e distantes, especialmente situadas nos municípios fumageiros. Esses dois equipamentos serviam para fazer o transporte de vários tipos de mercadorias provenientes de zonas adjacentes (principalmente o fumo) e do Sertão para o porto exportador em Salvador, ao tempo em que também cumpriam a função de receber e distribuir as mercadorias provenientes desta cidade ou que a ela chegavam como resultado do comércio inter-regional. 


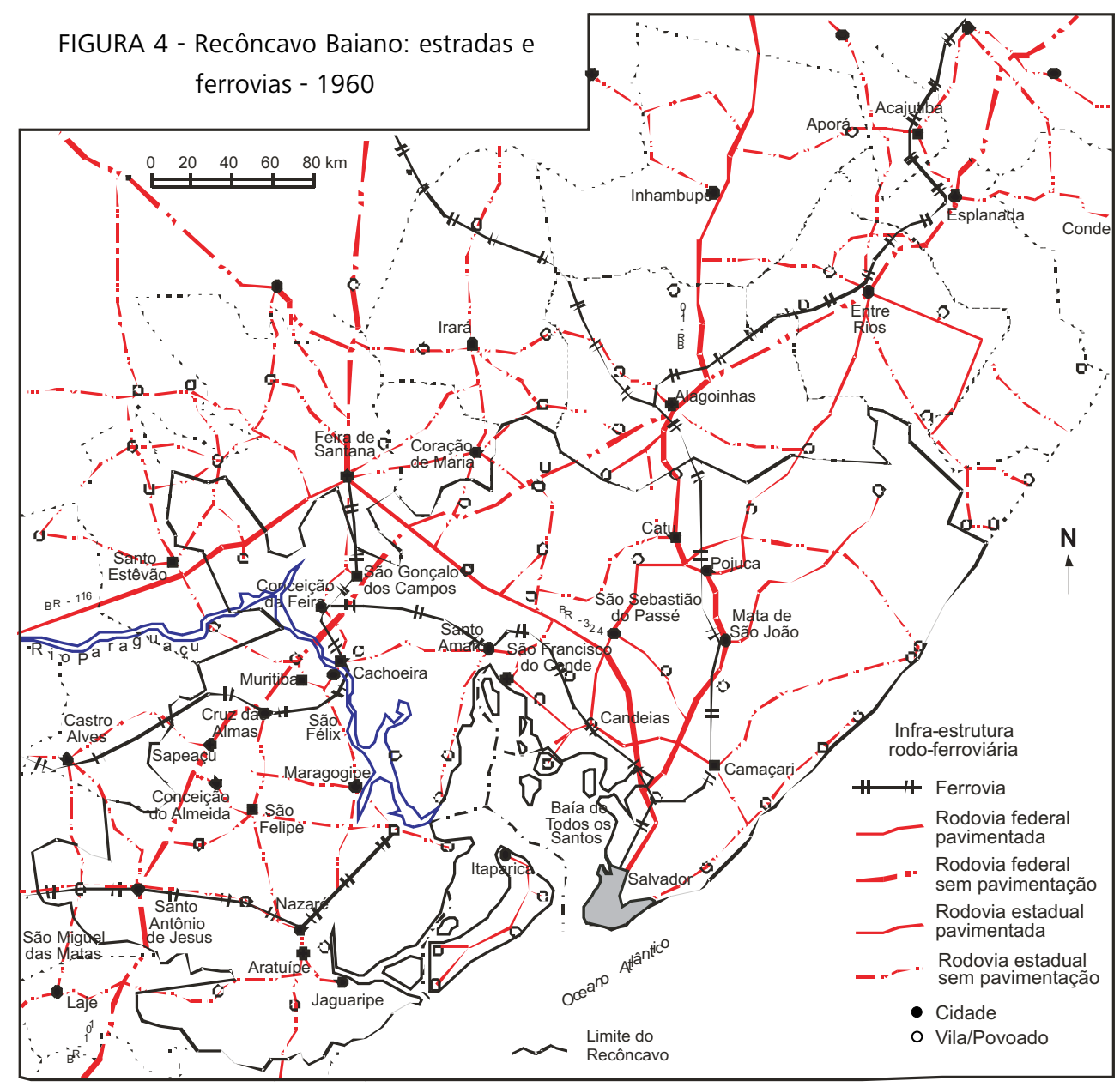

FONTE: Organizado por Brito (2004), com base em IBGE, 1954, 1958; Bahia, 1966; Santos, M. 1959a; A Bahia..., 2001.

Essa situação fez surgir na cidade de Cachoeira uma infraestrutura de apoio às atividades comerciais, manufatureiras, fábricas e trapiches de fumo, e à população em geral como, por exemplo, agências bancárias, sede da aplicação da justiça, serviços de entretenimento cultural, serviços de saúde, colégio de ensino médio, órgão da administração pública federal e estadual dentre outros.

A importância regional da cidade de Cachoeira era significativa, pois além da agência bancária da Caixa Econômica Federal, sediava ainda, segundo Azevedo, T.; Lins (1969) e Oliveira, W. (1993), agências dos dois maiores bancos regionais particulares - Banco da Bahia e Banco Econômico. Esses dois bancos também possuíam agência em São Félix, cidade contígua a Cachoeira, ambas unidas pela ponte e 
estrada de ferro sobre o rio Paraguaçu. Como uma extensão da cidade de Cachoeira, a cidade de São Félix tinha sua economia urbana também fundamentada no beneficiamento do fumo que coletava de sua hinterland e depois transferia para Cachoeira.

Numa posição de menor destaque aparece a cidade de Santo Amaro, liderando os núcleos urbanos em suas proximidades. Essa cidade também possuia porto fluviomarinho conectado a uma ferrovia, mas com movimentação de mercadorias pouco diversificada e baseada na exportação de açúcar para Salvador. Isso, sem dúvida, implicava uma forte limitação nas interações espaciais com outras cidades. Dada a grande extensão do município e a existência de vários núcleos urbanos importantes (sede de distritos), a maior influência urbana da cidade de Santo Amaro ocorria no próprio município e também nos outros dois municípios açucareiros - São Francisco do Conde e São Sebastião do Passé.

Na parte Norte do Recôncavo Baiano predominava um certo equilíbrio funcional entre os núcleos urbanos, todos de quarta ordem. Essa parte da hinterland compunha uma antiga área de fazendas de cana-de-açúcar, onde, inclusive, funcionaram dois engenhos centrais, o Pojuca e o da Mata, até o início do século XX. Já nos anos 1940, esse setor do Recôncavo Baiano havia se consolidado como área de policultura e de criação de gado, constituindo-se na mais importante bacia leiteira para o abastecimento da população de Salvador.

Essa parte do Recôncavo Baiano era servida pela estrada de ferro que ligava a cidade de Alagoinhas à capital, com estações de trem nas cidades de Catu, Pojuca, Mata de São João e Camaçari, além de demais vilas e povoados existentes ao longo desse trajeto. Além desse trajeto, a estrada de ferro Salvador/Alagoinhas (construída em 1876) bifurca-se, um ramal segue em direção ao alto Sertão, chegando até Juazeiro, na parte Noroeste da Bahia, e a outro ramal dirige-se para a direção Nordeste até Aracaju, capital do estado de Sergipe.

Por fim, todo o conjunto regional era influenciado pela capital baiana, que também mantinha contatos diretos com cada um dos centros urbanos e com as cidades de Alagoinhas e Feira de Santana, essa última que já assumia a função regional de distribuição das mercadorias que a ela chegava de caminhão proveniente do Sudeste/Sul, em decorrência de esta cidade estar situada junto aos mais importantes eixos rodoviários nacionais, a BR 116 (Rio-Bahia) e a BR 101.

Atravessando um longo período de transição entre a forma dendrítica consolidada pela estrada de ferro, pelos portos locais e pelos fluxos agromercantis declinantes que a animava - e a futura forma complexa, a rede urbana do Recôncavo Baiano, em fins dos anos 1940, tinha como principal característica o fato de ser o espelho de uma economia de tipo colonial, decorrente das ações dos grupos sociais que historicamente comandavam a vida social, política e econômica da Bahia. Em função disso, o que se 
reproduzia em grande medida era a pobreza e, como regra geral do sistema capitalista, as demandas derivadas da acumulação de capital tinham maior privilégio que as demandas ligadas à reprodução da força de trabalho (LOJKINE, 1981).

Esse fato é constatado ao se observar que nas cidades de Maragogipe (com cerca de 10.000 habitantes), São Félix (com quase 6.000 habitantes) e São Gonçalo dos Campos (com quase 4.000 habitantes) não havia escolas que ministrassem o ensino de nível médio. Por outro lado, esses mesmos núcleos urbanos eram dotados de agências bancárias, principalmente para o financiamento de atividades vinculadas à cultura e beneficiamento do fumo.

Enfim, em termos gerais esse era o Recôncavo Baiano, no qual a Petrobras se inseriu nos anos 1950 e a partir de então passou a reproduzi-lo em outras condições juntamente com os demais agentes sociais pré-existentes e os que, trazidos por ela, passaram a fazer parte das novas relações sociais e de produção que foram instaladas nesse território açucareiro/fumageiro em estágio de dissolução. 


\section{A inserção da Petrobras no Recôncavo Baiano}





\section{A inserção da Petrobras no Recôncavo Baiano}

Tem-se por pressuposto que os territórios são categorias espaciais historicamente construídas e que sua existência independe das qualidades da superfície subjacente aos seus limites. Os territórios, além de serem uma certa extensão do espaço geográfico, encerram também relações sociais mediadas pelo poder; relações essas que marcam a diferença entre o conceito de território e de espaço geográfico.

Que o espaço geográfico é um campo de forças não há dúvidas, mas qual o significado dessas forças e como elas se relacionam? Se os termos força, violência, coação, dominação e poder têm o mesmo sentido, então se trata de uma questão meramente funcional e serve entre outras funções, para o fim da dominação dos agentes mais fortes sobre os mais fracos. Em outras palavras, será que todos os tipos de relações sociais que se verificam em determinada parcela do espaço geográfico ocorrem sem o uso de coações/violência? Será que a existência de territórios é condicionada pela coincidência com a área de exercício da soberania de um Estado-nacional? Acredita-se que não, pois as guerras, como o ápice de toda violência, são fatos freqüentes na história social. Por sua vez, o Estado e dentro dele o Governo, em que pese sua importância política inigualável, constitui apenas mais um agente social entre os demais que, inclusive nas democracias, age mediante acordos formais, de outra maneira, torna-se uma tirania e somente os tiranos a defendem.

Assim sendo, não é exagero reafirmar que o espaço geográfico ou a totalidade social é uma categoria geográfica e os territórios formam outra. Estes resultam das relações sociais mediadas por acordos entre os distintos agentes que se interessam por dados objetos particulares inscritos numa dada porção do espaço geográfico. Os territórios possuem durabilidade e extensão relativizadas pelas dinâmicas próprias dos objetos que motivam os distintos agentes a se territorializarem.

Diante desse pressuposto, busca-se, neste capítulo, identificar, por meio das relações entre os agentes sociais relevantes que agem no Recôncavo Baiano, o momento e os elementos que levaram a Petrobras a abdicar do arbítrio com o qual se relacionava com seus interlocutores, bem como, as materializações que passaram a compor o território por ela organizada.

Esse momento foi marcado pelo surgimento de um consenso firmado tacitamente entre a companhia e os demais agentes que direta e/ou indiretamente se interessavam pelo desenvolvimento das atividades ligadas ao petróleo no Recôncavo Baiano. O sinal mais evidente da gênese desse consenso remonta à segunda metade dos anos 1960, quando a companhia já não representava mais 
um elemento estranho para os seus interlocutores e, por isso mesmo, também não precisava mais ser combatida.

Acredita-se que foi a partir desse momento que a empresa se projetou no Recôncavo Baiano como um agente hegemônico, tornando possível a emergência de um novo território, que vem sendo reproduzido por esse consenso em torno das atividades da empresa sem, contudo, deixar de contemplar os interesses dos demais agentes envolvidos no processo de organização e reprodução do território.

Para prosseguir na análise faz-se mister compreender o processo de constituição da Petrobras, sua inserção no Recôncavo Baiano, bem como as formas de coexistência com os demais agentes existentes e/ou que surgiram a partir das ações dessa companhia.

\section{Da criação da Petrobras à produção de óleo e gás na- tural no Recôncavo Baiano}

O movimento tenentista da década de 1920 e o golpe militar de 1930 implementaram uma nova era na história e geografia brasileira, já reclamada por movimentos artístico-culturais de autonomia nacional, principalmente a Semana de Arte Moderna, de 1922. De cunho liberal, invocando, porém, um sentimento nacionalista e programaticamente centralista, o governo Vargas, apoiado nos oficiais militares, foi responsável pela implantação de uma nova mentalidade social, com a qual pretendia suprir o país com um novo código de normas sociais, econômicas e políticas, além de uma infraestrutura física para promover a unificação e a centralização do Estado e do mercado nacionais.

É nessa senda que ganha fôlego o projeto de autonomia do desenvolvimento nacional liderado pelos militares, com especial destaque para a implantação da grande indústria do aço no Brasil. A instalação da Companhia Siderúrgica Nacional (CSN), em meio a uma conjuntura de guerra internacional, contou com o apoio financeiro, tecnológico e gerencial de empresas e do Governo dos Estados Unidos, país considerado nos meios palacianos e empresariais privados brasileiros como o grande parceiro econômico e militar do Brasil. Ainda durante a Segunda Guerra, por razões de segurança, o Governo federal criou a Fábrica Nacional de Motores (1940), para produzir motores de avião, tratores, caminhões, automóveis e refrigeradores; a Companhia Nacional de Álcalis (1943), para manter o fluxo de matérias-primas para as indústrias de derivados de barrilha; a Companhia Vale do Rio Doce (1942) para o fornecimento de minérios de ferro à futura indústria do aço e outros empreendimentos estatais (WIRTH, 1973). 
O movimento autonomista brasileiro dessa época pretendia dar solução para a maioria dos problemas ligados ao desenvolvimento econômico recorrendo, no entanto, à tutela financeira e tecnológica principalmente dos norte-americanos. Essa perspectiva, durante o Estado Novo, era corroborada também pelos prepostos de distintos grupos econômicos nacionais e estrangeiros localizados e representados por titulares de pastas do alto escalão do Governo, como, por exemplo: Artur Souza Costa (Ministro da Fazenda), Pedro Rache (Presidente do Banco do Brasil), Souza Aranha (Ministro do Exterior), Valentim Bouças (Secretário do Conselho Técnico de Economia e Finanças) e outros (WIRTH, 1973). Esses grupos econômicos e políticos, que não eram homogêneos em seus interesses, estavam ligados comercialmente a outros grupos econômicos internacionais rivais - norte-americanos ou alemães.

Para além de uma aliança comercial entre os distintos grupos econômicos nacionais e estrangeiros e os governos brasileiro e norte-americano, essa forte aproximação representava também lances de estratégia de aliança militar no continente americano.

Essa mesma idéia se encaminhava também para o problema do petróleo brasileiro, mas deparou-se com uma resistência maior e mais organizada surgida no meio militar, como uma questão de segurança nacional em meio a uma conjuntura de guerra internacional de grandes proporções.

Desde o início do século $\mathrm{XX}$, o Governo brasileiro já vinha reunindo esforços para encontrar petróleo no Brasil. Todas as tentativas, todavia, eram bastante limitadas e, em muitos casos, desestimulantes para prosseguir a busca de petróleo no subsolo brasileiro, seja por falta de tecnologia de prospecção, e/ou por falta de recursos, ou mesmo por sabotagem das empresas controladoras do trust mundial do petróleo a exemplo da Royal Dutch-Shell e da Standard Oil of New Jersey (VICTOR, 1970; MARINHO JR., 1989). Contudo, foi no subsolo do Recôncavo Baiano que o petróleo surgiu em abundância no Brasil, em 1939.

Enquanto as pesquisas de petróleo e gás natural expandiam-se no país e, em especial, no Recôncavo Baiano, desde os anos 1930, no meio governamental e legislativo nacional vinham-se desenvolvendo intensas discussões sobre o problema do petróleo no país. Essas discussões resultaram, num primeiro momento, na criação de normas rigorosas e específicas, na tentativa de inibir a cobiça dos trusts mundiais do petróleo com a publicação do Código de Minas de 1934 e de 1940; na criação do CNP em 1938 e, por fim, na nacionalização para a pesquisa, a lavra e o beneficiamento do petróleo.

A criação e a respectiva aplicação dessas normas ocorreram ao longo de mais de duas décadas; uma luta, ora mais, ora menos agressiva, com posições dentro e fora do Governo, e entre os agentes empenhados em defender os interesses do capital privado nos negócios do petróleo no Brasil contra os grupos nacionalistas. 
Do lado do capital privado destacava-se o empresariado nacional: Grupo Matarazzo, União, Ernany-Magalhães e Ipiranga, embora sem o volume de capital necessário aos investimentos e nem a tecnologia adequada. Esses grupos econômicos buscavam participar das atividades relacionadas ao petróleo, associados aos grandes grupos estrangeiros liderados pela Standard Oil of New Jersey (norte-americano) e pela Royal Dutch-Shell (anglo-holandês-franco) que há muito tempo estavam presentes no Brasil, na distribuição de derivados de petróleo importados.

A Standard Oil of New Jersey e a Royal Dutch-Shell tinham interesses bem definidos no petróleo brasileiro e no mercado de derivados, mas mantinham oculto o objetivo essencial, que era o de tentar aumentar suas reservas de petróleo em virtude da concorrência monopolística entre as grandes companhias que dominavam mundialmente os negócios de petróleo. Nesse sentido, Victor (1970) destaca o comentário do presidente de uma das maiores companhias de petróleo do mundo, a Standard Oil of New Jersey, em 1920, em relação aos EUA:

[...] por sua situação no comércio mundial, pelas armas financeiras e econômicas que possuem, poderiam - exigir uma nova partilha de terrenos petrolíferos estrangeiros para assim dispor de uma parte dos bens que outras nações pretendem conservar inteiros para si próprias (VICTOR, 1970, p. 52).

Dentro do Governo federal havia dois grupos políticos distintos: um liderado pelo General Juarez Távora e por alguns ministros, como Souza Costa (da Fazenda) e Mendonça Lima (dos Transportes), que defendia a associação direta com o capital nacional e estrangeiro, principalmente norte-americano; em oposição a este, colocava-se o de linha nacionalista e centralista, defensor do monopólio integral do petróleo operado pelo Estado brasileiro por intermédio do CNP, liderado pelo General Horta Barbosa.

Juarez Távora e Horta Barbosa eram oficiais do exército, ex-militantes do movimento tenentista. O primeiro foi Ministro da Agricultura e mentor do CNP, no primeiro período da era Vargas, assumiu, porém, uma linha mais liberal na fase do Governo Dutra; o outro foi o primeiro presidente do CNP, de linha mais avessa à participação do capital externo nos assuntos considerados de segurança nacional, como o petróleo, por exemplo.

Do âmbito do Governo, os debates sobre a questão do petróleo brasileiro estenderam-se para o Congresso Nacional e também para a opinião pública, com maior ênfase a partir de 1946, quando então ganhou as ruas a campanha nacional "O Petróleo é Nosso". Desse período em diante, pós-ditadura Vargas, houve mudanças importantes na legislação sobre o petróleo, permitindo a participação do capital privado e estrangeiro na refinação e distribuição do petróleo e seus 
derivados, inclusive com autorizações para construção de refinarias estatais e privadas durante a administração do presidente Dutra.

Entre o fim do "Estado Novo" e a criação da Petrobras, em 1954, o Governo brasileiro estava comprometido com o problema criado em decorrência da necessidade premente de explorar o petróleo e desenvolver a indústria petrolífera, embora, sem dispor do volume de capital e de tecnologia necessárias para dar consecução ao projeto da indústria brasileira de petróleo. Subjacente a essa questão pairava entre os grupos nacionalistas do Governo o receio de não ser capaz de controlar as decisões das grandes companhias estrangeiras de petróleo, as quais certamente instituiriam o monopólio privado e dominariam o setor de petróleo no Brasil, caso fosse permitida a participação da livre empresa nos negócios do petróleo. Esses fatores alimentavam as discussões contra e a favor de uma lei que instituía o monopólio estatal do petróleo e o respectivo órgão de operações.

Com o retorno de Vargas ao Governo, já num ambiente político democrático, o presidente enviou ao Congresso Nacional, em 1951, o Projeto de Lei n 1.516 que criaria a sociedade por ações Petróleo Brasileiro S/A (Petrobras) ${ }^{1}($ WIRTH, 1973). O Projeto de Lei previa a organização de uma empresa que admitia a participação acionária do capital privado, nacional e estrangeiro. Fora do ambiente palaciano, no entanto, predominava um cenário político oposto às diretrizes do Governo, com a forte campanha nacionalista em prol do monopólio estatal do petróleo. Com isso, a iniciativa do Governo foi alvo de várias críticas dos parlamentares defensores de posições mais agressivas a favor do monopólio estatal do petróleo (PCB, PSD e PTB) e, inclusive, dos parlamentares da União Democrática Nacional (UDN), que eram contrários ao monopólio estatal do petróleo, mas que, diante da forte campanha popular em defesa do monopólio do petróleo aderiram ao projeto do monopólio integral do petróleo.

Dos debates no Congresso Nacional originou-se a lei aprovada pela maioria dos parlamentares, que criava a Petrobras e Ihe conferia o monopólio estatal do petróleo para lidar com todos os campos de atividades a ele ligado.

A Petrobras foi criada pela Lei $n^{\circ} 2.004$ de outubro de 1953, fruto de um longo e trabalhoso processo de entendimentos entre o Governo e as lideranças partidárias no Congresso Nacional desde dezembro de $1951^{2}($ WIRTH, 1973).

\footnotetext{
${ }^{1}$ Quem elaborou o projeto de criação da Petrobras foi o grupo liderado pelo economista baiano Rômulo Almeida que reaparece em fins dos anos 1960 com o projeto de instalação da indústria petroquímica na Bahia.

2 Para uma compreensão mais detalhada das discussões e do processo de criação da Petrobras e de toda a legislação brasileira a respeito das atividades ligadas ao petróleo ver: COHN, G. (1968); VICTOR (1970); WIRTH (1973); CARVALHO (1977); MARINHO JR (1989).
} 
A exemplo da indústria do aço, mas por meio de um processo distinto, a Petrobras foi criada sob o signo do progresso e do desenvolvimento econômico nacional; portanto, um consenso de âmbito nacional e politicamente bem amplo, embora continuassem pequenos focos de oposição dentro do Governo e entre os parlamentares no Congresso Nacional que defendiam uma solução com a participação do capital estrangeiro, como o foi a implantação da CSN durante a Segunda Guerra.

Criada a Petrobras com um aporte de capital inicial de $\mathrm{Cr} \$ 4$ bilhões (cerca de U\$ 67,1 milhões) subscritos pela União, e determinadas as fontes de suprimento de capital para sua implementação, a empresa foi formalmente constituída em maio de 1954, com a determinação de atender às necessidades prementes de auto-suficiência em petróleo sob a crítica constante (interna e externa) dos grupos políticos e econômicos que a todo o momento tentavam desacreditar a aventura do Estado brasileiro em manter o domínio do monopólio e o abastecimento do mercado nacional com petróleo brasileiro e derivados.

Conforme Petrobras (1989) e artigo da Revista Petrobras (CAPITAL..., 1961), as fontes de recursos para o financiamento da Petrobras no período eram: o Imposto Único sobre Combustíveis Líquidos e Lubrificantes, o Fundo Rodoviário Nacional e o Imposto de Importação de Consumo de Veículos Automotores - aéreos, terrestres e aquáticos e também as receitas próprias. Em 1955, para um capital total de Cr\$ 6 bilhões (equivalente a quase U\$ 84 milhões), os recursos provenientes de receitas próprias perfazia um percentual de $42,49 \%$, enquanto que em 1960 o capital total da empresa somava $\mathrm{Cr} \$ 40$ bilhões (equivalente a quase U\$ 215 milhões) e o percentual de receitas próprias aumentou para $79,64 \%$.

Com a constituição da Petrobras o CNP foi transformado em um órgão regulador da política nacional de petróleo e transferiu para a nova empresa todo o seu patrimônio, incluindo recursos financeiros, máquinas, uma frota de petroleiros com 22 navios, a pequena refinaria de Mataripe, o corpo de funcionários, os campos de petróleo e gás e as jazidas de xisto betuminoso existentes nos estado do Paraná e de São Paulo.

\section{As ações da Petrobras no Recôncavo Baiano}

No Recôncavo Baiano, a única província petrolífera nacional até os anos 1960, as pesquisas e a exploração do petróleo e do gás natural, que vinham sendo implementadas em ritmo acelerado pelo CNP (descoberta dos campos de: Lobato/ Joanes (1939), Candeias (1941), Aratu (1941), Itaparica (1942), Dom João (1947), Pedras (1950), Paramirim (1951), Água Grande (1951), Mata de São João (1953), 
Pojuca-Central (1953) e os campos marítimos da Baía de Todos os Santos), foram ampliadas mais ainda com a participação da Petrobras, por meio de procedimentos mais sistemáticos de pesquisa e aproveitamento do óleo, resultando nas descobertas de novos e maiores campos de petróleo e gás até fins dos anos 1950: Taquipe em 1958 e Buracica em 1959 (FERNANDES, 1958; RPBA, 1975).

As respostas negativas das pesquisas de petróleo em outras partes do país, as recomendações dos técnicos e a necessidade do suprimento de óleo requerido pela demanda nacional, a qual se ampliava a cada ano, fizeram com que a Petrobras, por medida econômica, buscasse intensificar a produção de óleo no Recôncavo Baiano.

O grande volume de óleo produzido no Recôncavo Baiano era surpreendente. Segundo as metas de produção nacional de óleo da Petrobras, o volume mínimo a ser produzido deveria chegar a 40 mil barris de petróleo por dia (bpd) no período de 1956 a 1960, ou seja, 21\% do consumo e 33\% do petróleo refinado no país. Todavia, em fins de 1957, essa meta já havia sido atingida (LANGE, 1959) e em 1958 chegou a 75 mil bpd (BARROSO, 1959), com a perspectiva de ultrapassar a barreira dos 100 mil bpd em 1960.

De acordo com os dados oficiais (PETROBRAS, 1993 apud RAMIRES, 1991, p. 124), até 1973 o Recôncavo Baiano era responsável por $80 \%$ da produção nacional de petróleo, diminuindo progressivamente com as descobertas de grandes jazidas petrolíferas noutras partes do país, em especial, na plataforma continental, com destaque para a Bacia de Campos-RJ.

Mesmo com o significativo aumento anual de produção nacional de óleo, a oferta de produtos derivados do petróleo provenientes das refinarias brasileiras ainda era insuficiente diante da demanda nacional. Em 1955, as seis refinarias instaladas no Brasil processavam mais de 80 mil bpd de petróleo; essa quantidade, contudo, atingia apenas $37,7 \%$ da demanda de derivados (SCHOR, 1959). Em 1959, as refinarias brasileiras já haviam duplicado a capacidade de refino de petróleo; a tão esperada auto-suficiência nacional em óleo cru era, todavia, um limite ainda muito distante de ser alcançado.

O Brasil dos anos 1950 mudara significativamente, sobretudo a partir da segunda metade dessa década, com a instalação da indústria automobilística, a aceleração do processo de urbanização e o consequente aumento do consumo de derivados de petróleo como sublinha Marinho Jr. (1989, p. 260):

O Brasil da descoberta do petróleo em Lobato mudara. As estatísticas mostravam que o petróleo e seus derivados tinham conquistado definitivamente a posição de primeira fonte de energia do país. Em termos de demanda corrente, a taxa de crescimento que tinha sido de $11,3 \%$ no período 1939-40, pulou para $22,4 \%$ em 1950. Isto porque, em 1950, a taxa anual do crescimento da produção industrial tinha sido de $5 \%$ a $6 \%$, o parque rodoviário nacional tinha expan- 
dido extraordinariamente, o crescimento da população tinha alcançado um dos mais elevados índices do mundo e a implementação da tração diesel nas vias férreas tinha começado, acontecendo o mesmo com a mecanização agrícola.

Para aumentar o grau de complexidade do problema da auto-suficiência do petróleo no Brasil, destaca ainda Marinho Jr. (1989, p. 261):

[...] a produção de óleo bruto na única província petrolífera em exploração correspondia, apenas, a $2 \%$ do consumo interno em 1953. Eis a razão de o petróleo e seus derivados se terem tornado um dos mais importantes, senão o maior item, de nossa pauta de importação, absorvendo quotas cada vez maiores provenientes da exportação nacional, numa proporção de 7,9\% em 1939, de 10,4\% em 1950 e de 17,7\% em 1952.

Dessa maneira, logo se depreende que o Recôncavo Baiano, em nome do consenso firmado na escola nacional em torno da Lei $n^{\circ} 2.004$, teria, a todo custo, que buscar reverter esse quadro bastante desfavorável à entrada de capitais provenientes das exportações brasileiras. Ao lado dos esforços da Petrobras em encontrar petróleo em outras partes do país, sem o respectivo aporte de capital e técnicas suficientes, ao longo do tempo, as atividades da companhia foram avançando sobre as terras da Bacia Sedimentar do Recôncavo, abrindo novos campos de exploração de petróleo e gás nos municípios localizados ao norte de Salvador.

A instalação da Petrobras na Bahia, em substituição ao CNP, alimentava, nas forças políticas e econômicas regionais, esperanças de reativação da economia baiana em bases industriais. Contudo, a instalação de empreendimentos industriais geradores de sinergias não se concretizava. Essa situação provocava uma forte insatisfação entre os grupos políticos e econômicos regionais, tendo em vista o fato de a companhia limitar-se à exploração e produção do óleo e do gás natural. Além disso, a refinação de óleo era bastante pequena em relação à produção de óleo que era de cerca de 100 mil bpd entre 1959 e 1960 e também não aproveitava integralmente as qualidades excelentes do óleo parafínico, indicado para a produção de lubrificantes ${ }^{3}$.

Em sentido semelhante estava a utilização do gás natural que era quase simbólica diante da grande potencialidade de aplicação na indústria petroquímica e de fertilizantes que ainda não havia se instalado na Bahia e o valor do royalty devido ao estado da Bahia e aos municípios petrolíferos era muito baixo. Além

\footnotetext{
${ }^{3}$ Os óleos lubrificantes são produtos de alto valor agregado e além disso, àquela altura, a Petrobras não se interessava em produzi-los, o que tecnicamente ocorreria no Recôncavo, e o abastecimento do mercado brasileiro era feito com óleo importado do exterior.
} 
disso, a Petrobras, ao contrário do que seus interlocutores regionais esperavam, tendo em vista a concepção política da criação da estatal, voltada para uma ação essencialmente macroeconômica privilegiando investimentos numa perspectiva de política governamental, como instrumento de progresso econômico e social, a companhia agia numa perspectiva essencialmente microeconômica no Recôncavo Baiano, desconsiderando quase que completamente os pleitos dos demais agentes sociais existentes em seu entorno.

Se no plano eminentemente local e isolado, concomitantemente com o início das explorações de petróleo no Recôncavo Baiano por meio do CNP (na década de 1940), registraram-se algumas reações por parte dos fazendeiros e usineiros, em outro plano e, um pouco mais tarde, diante da falta de iniciativa da Petrobras em implantar indústrias na Bahia, o sentimento de insatisfação se generalizava no Governo estadual. Esse fato tornava-se patente com a constatação de que o estado da Bahia continuava empobrecendo e sua economia, acanhada, subsistia com a exploração de atividades primário-exportadoras, isso após quase duas décadas de produção ininterrupta e fornecimento exclusivo à nação de todo o óleo ali produzido até então.

Cumpre esclarecer, antes de tudo, que não cabe atribuir à Petrobras a infelicidade e a pobreza econômica e social do estado da Bahia, tendo em vista essa situação ser reflexo de um processo engendrado pelos próprios agentes sociais regionais - grandes comerciantes, usineiros, banqueiros, coronéis, fazendeiros... -, os quais, historicamente dominavam a economia regional e se beneficiavam com os resultados comerciais da dinâmica da economia agromercantil, e que após a Segunda Guerra Mundial já se encontrava em uma fase aguda de encerramento do seu ciclo. Contudo, nesse período, a Petrobras contribuía para a formação da riqueza na Bahia, embora em estado pouco dinâmico, apesar de lidar com um produto de grande potencial de geração de riqueza num nível superior ao das antigas indústrias de fumo e do açúcar principalmente.

Apesar da volumosa soma de recursos financeiros aplicados diretamente no Recôncavo Baiano ao longo de cinco anos, tais recursos não se traduziam em investimentos propiciadores de um futuro desenvolvimento econômico regional baseado em atividades industriais. Nessas condições, ainda que os investimentos da Petrobras tivessem a natureza distinta daquela esperada diante da abundância da matéria-prima, eles não poderiam ser desprezados, em conseqüência do grande volume de recursos aplicados em várias obras e serviços. Todavia, os investimentos da Petrobras na Bahia resumiam-se às obras de ampliação da refinaria, aos convênios para abertura e asfaltamento de estradas no Recôncavo Baiano e a outros gastos com suprimentos de serviços por firmas locais. Com isso, o seu papel econômico regional era limitado e quase que absolutamente voltado aos interesses próprios da companhia. 
Como resultado das ações predominantemente microeconômicas da Petrobras no Recôncavo Baiano tomava corpo um forte grau de insatisfação entre os seus interlocutores regionais, que aumentava progressivamente e tornava-se uma ação declarada contra a companhia. No campo de oposição a esse tipo de ação da Petrobras estavam: o Governo do estado, os Governos dos municípios petrolíferos, os grupos econômicos, políticos e os trabalhadores da própria empresa; os últimos se manifestavam por meio de greves em defesa de melhores salários e condições de trabalho e/ou adesão aos protestos dos primeiros.

Entre as ações da companhia que desagradavam os citados agentes destacase, primeiramente, o fato de que desde o início das explorações e produção de óleo e gás natural com o CNP e depois com a Petrobras, os campos de petróleo do Recôncavo Baiano respondiam de maneira positiva e acelerada ao aumento da demanda de óleo cru no país. Para ilustrar, em fins de 1959 o volume de produção de óleo nos campos do Recôncavo Baiano atingiu cerca de 100 mil bpd (BAHIA, [1960?]); contudo, a capacidade de refino da Refinaria Landulpho AlvesMataripe (RLAM) ainda era de apenas 10 mil bpd, ou seja, na Bahia era processado apenas $10 \%$ de todo o óleo produzido na Região de Produção da Bahia (RPBA), conforme dados da Refinaria..., [2000?]. Contudo, nesse mesmo ano os trabaIhos de ampliação da RLAM já estavam em fase de conclusão, o que aumentaria o volume de processamento de óleo para 42,5 mil bpd a partir de 1960.

Nessas condições, a refinaria de Mataripe havia se tornado deveras pequena em relação à grande oferta de óleo do Recôncavo Baiano e à maior capacidade de refino das demais refinarias, inclusive as particulares, existentes noutros estados (Tabela 9). Além disso, a RLAM estava limitada apenas à produção dos seguintes produtos: gasolina, querosene, óleo diesel, óleo combustível e gás liquefeito de petróleo. Entrementes a Refinaria Presidente Bernardes-Cubatão (RPBC), no estado de São Paulo, construída em 1955, com capacidade para processar 45 mil bpd, um ano depois foi ampliada para 65 mil bpd e já produzia asfalto. Em 1958 a RPBC foi ampliada novamente, atingindo quase 80 mil bpd e iniciou a produção de insumos petroquímicos básicos (eteno, propeno, metano, hexano) e deu partida às unidades de amônia e fertilizantes, que são produtos derivados do processamento da nafta importada. ${ }^{4}$

\footnotetext{
${ }^{4}$ Antevendo o promissor e dinâmico mercado dos produtos petroquímicos, o CNP, ao autorizar a construção da refinaria RPBC, concebeu o projeto de modo a utilizar o processo de cracking (obtenção de derivados de petróleo por meio de calor e pressão) com o fito de obter frações de produtos petroquímicos básicos (DA POIAN, 1981). Os produtos petroquímicos básicos derivados do petróleo são: gás residual, eteno, propeno, butenos, butadienos, benzeno, tolueno e xilenos; já os derivados do gás natural são: gás de síntese, metano, acetileno, eteno propeno e butenos (MASCARENHAS, 1973).
} 
O tamanho reduzido da RLAM impedia a produção de outros produtos de elevado rendimento econômico, como óleos lubrificantes, insumos básicos da cadeia petroquímica (estes com a utilização do gás natural) e parafina, os quais já poderiam ser produzidos há mais tempo, com a instalação de uma unidade de lubrificantes e a ampliação da refinaria para o processamento de 30 mil bpd. Essa medida possibilitaria o aproveitamento do óleo do Recôncavo Baiano com alto teor de parafina, recomendado para a produção de lubrificantes, pois esses produtos ainda não eram fabricados no Brasil e, por isso, consumiam parte significativa das divisas brasileiras com a sua importação, o que poderia, então, ser evitado.

Apesar de ter sido a primeira refinaria estatal construída, a capacidade de refino da RLAM ocupava apenas a quinta posição em volume de processamento de óleo. Isso se deve à política adotada pela Petrobras, a qual tendia a priorizar mais a eficiência dos rendimentos econômicos da companhia, baseando grande parte dos investimentos nas áreas de maior mercado consumidor, em detrimento de uma proposta alternativa de busca de realização econômica e promoção do desenvolvimento equitativo das regiões brasileiras. Como resultado dessa política de concentração de investimentos da Petrobras próximo à área de maior mercado de consumo de seus produtos, quase $80 \%$ do parque refinador nacional localizava-se no estado de São Paulo, como evidencia as informações da Tabela 9.

Tabela 9 - Brasil: refinarias de petróleo e capacidade de refino (bpd) - 1959

\begin{tabular}{l|l|c}
\hline \multicolumn{1}{c|}{ Refinarias } & \multicolumn{1}{c|}{$\begin{array}{c}\text { Localização / Unidade } \\
\text { da Federação }\end{array}$} & $\begin{array}{c}\text { Capacidade } \\
\text { de Refino }\end{array}$ \\
\hline Presidente Bernardes (Cubatão) & São Paulo & 93.095 \\
Capuava & São Paulo & 28.105 \\
Ipiranga & Rio Grande do Sul & 11.115 \\
Manguinhos & Rio de Janeiro & 9.551 \\
Mataripe & Bahia & 9.105 \\
Manaus & Amazonas & 4.298 \\
Matarazzo & São Paulo & 1.012 \\
Uruguaiana & Rio Grande do Sul & 172 \\
\hline
\end{tabular}

FONTE: Organizada por Brito (2004), com base em Schor (1959).

Os critérios de localização dos grandes empreendimentos da companhia seguiam fielmente a clássica Teoria da Localização Industrial, de Alfred Weber, segundo analisa Manzagol (1985). Isso pode ser constatado na explanação de Fonseca (1959), ao se referir ao ponto ótimo de localização das refinarias da Petrobras:

A refinação do petróleo utiliza uma única matéria-prima e é mínima aquela redução de peso, que praticamente se resume ao consumo de 6\%; quanto ao custo do transporte, os fretes de petróleo cru são inferiores àqueles cobrados para derivados em geral. Esses dois fatores exercem, portanto, sua fôrça de atração no mesmo sentido, que é o de aproximar as refinarias dos mercados consumidores. Esta é uma regra de aceitação geral (FONSECA, 1959, p. 84). 
Conforme a explanação de Fonseca (1959), estavam assim distribuídas geograficamente a capacidade de refino e as áreas de mercado da Petrobras no Brasil, em 1959:

I - MANAUS (produção de 5.000 bpd) - suprindo do Acre ao Piauí, inclusive com um consumo de 6.000 bpd; abrangerá as atuais bases de provimento de Manaus e Belém.

II - MATARIPE (produção atual de 10.000 bpd) - deverá abastecer do Ceará ao Espírito Santo, cujo consumo alcança 30.000 bpd; absorverá as atuais bases de Fortaleza, Natal, Cabedelo, Recife, Maceió, Salvador e Vitória.

III - Rio de Janeiro (produção atual de 10.000 bpd) - devendo suprir o Distrito Federal e os Estados do Rio de Janeiro e Minas Gerais, cujo consumo atual é de 65.000 bpd; abrangerá apenas a base do Rio de Janeiro.

IV - SANTOS - SÃO PAULO (produção atual de 125.000 bpd) - compreenderá São Paulo, Paraná, Santa Catarina, Mato Grosso, Goiás e pequena parte de Minas Gerais com um consumo de 105.000 bpd; abrangerá as atuais bases de Santos e Paranaguá.

V - RIO GRANDE (produção atual de 10.000 bpd) - compreenderá o estado do rio Grande do Sul, com consumo atual de 20.000 bpd; absorverá apenas a base de Rio Grande (FONSECA, 1959, p. 87).

Do exposto, vê-se que, na prática, a política de investimentos industriais da Petrobras, para o referido período, resulta num indisfarçável privilégio dos investimentos da empresa no estado de São Paulo, inclusive com excesso de produção de refinados, de quase $20 \%$, enquanto todas as demais áreas de mercado registravam déficit, a exemplo do estado da Bahia.

Contraditoriamente, essa concentração de investimentos da indústria petrolífera em São Paulo contribuía como um elemento a mais para a crise de realização econômica iniciada em 1962 e que se prolongou por um lustro. A crise ocorreu pelo excesso de oferta de capacidade industrial instalada (no eixo econômico São Paulo/Rio de Janeiro) diante de um mercado de consumo urbano limitado numérica e qualitativamente. Essa crise somente foi debelada a partir da forte intervenção (da reforma fiscal/financeira e dos investimentos do Setor Público Estatal (SPE)) do primeiro governo militar instalado com o golpe de 1964 (TAVARES, M., 1986; CASTRO, 1975).

Outro tipo de ação empreendida pela Petrobras e que não atendia a outros interesses, senão os da própria empresa, era a utilização do gás natural. À época, o gás natural existia em abundância nos campos de petróleo do Recôncavo Baiano, mais de 4 bilhões de metros cúbicos misturados ao óleo e nos próprios campos de gás (BARROSO, 1959). Até fins de 1950, o uso dessa matéria-prima estava destinado apenas para reinjeção nos poços de petróleo, com a finalidade de garantir a manutenção da pressão do óleo no interior dos poços, tornando mais fácil a recuperação do óleo existente nos poros das rochas. Uma baixa pressão ou 
a ausência dela no interior dos poços de petróleo implica uma redução significativa da quantidade de óleo que pode ser recuperado, devido à força de adesão das moléculas do óleo que se prendem à superfície das rochas.

O gás natural é considerado uma matéria-prima ideal e de larga aplicação nas indústrias químicas e petroquímicas em geral; também o é na indústria de fertilizantes, devido às suas propriedades físico-químicas. A decisão da Petrobras, entretanto, era de não ceder seu uso para fins industriais, com o argumento de que o volume de gás até então disponível, 4,113 bilhões de metros cúbicos, não era suficiente para o aproveitamento industrial.

Com essa decisão, a Petrobras vedava a possibilidade de utilização do gás natural por outras firmas industriais, a exemplo da empresa Nitrogênio $S / A$, que se propunha a produzir 26 mil toneladas/ano de fertilizantes nitrogenados, consumindo apenas 90 mil metros cúbicos de gás por dia, ou seja, menos de um bilhão de metros cúbicos de gás ao longo de 30 anos. Por seu turno, a mesma quantidade de gás era consumida pela usina termoelétrica instalada na localidade de Cotegipe (SÁ, 1959), e também por uma fábrica de cimento localizada em Aratu (AZEVEDO, T., 1959a), ambas no município de Salvador.

A rigor, essa determinação da Petrobras, de impossibilitar a utilização do gás natural do Recôncavo Baiano para fins de aplicação na indústria petroquímica, escondia uma intenção velada, qual seja, agir preventivamente no sentido de reservar para si a matéria-prima que seria utilizada futuramente no promissor mercado de produtos petroquímicos. O fato revelador dessa intenção é identificado pela própria preocupação da tecnoburocracia do CNP e da própria Petrobras que estava receosa com o avanço e a autonomia das empresas estrangeiras no setor petroquímico brasileiro, conforme observam Da Poian (1981) e Suarez (1986). ${ }^{5}$

Em face da incapacidade financeira e tecnológica dos grupos econômicos nacionais e da resistência dos quadros dirigentes do CNP e da Petrobras em abrir brechas para a penetração do capital estrangeiro, o CNP autorizou esta empresa a produzir também matérias-primas petroquímicas, no sentido de evitar o surgimento da indústria petroquímica dominada pelo oligopólio privado internacional no Brasil (DA POIAN, 1981).

Com isso, a Petrobras passou a produzir diretamente os produtos petroquímicos básicos na refinaria de Cubatão e adquiriu o monopólio da importação de nafta que, por meio de contratos comerciais, fornecia parte das matérias-primas às empresas de segunda geração e de bens finais.

Agindo dessa maneira, a Petrobras e o CNP fechavam as possíveis portas de entrada do capital estrangeiro que poderia ser levado pelo empresariado nacional.

\footnotetext{
${ }^{5}$ Da Poian era um executivo da tecnoburocracia petroleira.
} 
Com esse tipo de ação, a tecnoburocracia petroleira também condenava a Bahia a permanecer cumprindo papel somenos importante na divisão espacial da produção, como uma província fornecedora de matérias-primas, pois a própria companhia não se interessava em criar empreendimento petroquímico na Bahia. ${ }^{6}$

Vale destacar que a usina da Companhia Hidrelétrica do São Francisco (Chesf), construída para gerar energia elétrica para a região Nordeste, já havia sido inaugurada desde 1955; portanto, se houvesse interesse da Petrobras em dar uma utilização mais nobre para o gás natural que era consumido como combustível, poderia ter sido desativada a usina termoelétrica de Cotegipe e transferido seu consumo de gás natural para produção de fertilizantes, bem como, o gás natural utilizado na fábrica de cimento localizada em Salvador.

À época, na opinião de técnicos em assuntos de petróleo, para que uma refinaria pudesse fornecer uma quantidade suficiente e regular de matéria-prima (nafta e demais gases derivados do processo de destilação do óleo) para uma planta petroquímica economicamente viável, deveria ter uma capacidade de refino de óleo de pelo menos 90 mil bpd; a RLAM, com capacidade de refinar 10 mil bpd de óleo e sua ampliação para 42,5 mil bpd, em 1960, não tinha condições técnicas suficientes para fornecer à indústria petroquímica os subprodutos da refinação do óleo. Nessas condições, forçosamente era vedada a instalação desse tipo de indústria no Recôncavo Baiano.

Nos anos seguintes, a produção de óleo aumentava cada vez mais, com a descoberta de novos campos de petróleo, de maneira que, no fim dos anos 1960, a produção de óleo no Recôncavo Baiano atingiu o limite máximo de 150 mil bpd (A BAHIA..., 2001) e, por conseguinte, a produção de gás natural crescia de maneira exponencial. Isso contradizia a política de restrição aos investimentos industriais na Bahia por parte da Petrobras.

Uma segunda modalidade de ação da empresa que era contrária aos interesses de seus interlocutores regionais era o fato de a renda proveniente das taxas de participação acionária na companhia e os royalties devidos ao estado da Bahia e aos municípios petrolíferos, pelo óleo extraído no Recôncavo Baiano, somente começarem a ser pagos a partir de 1955, um ano depois da constituição da Petrobras e 14 anos depois do início da exploração e produção comercial do óleo pelo CNP. Quando os royalties passaram a ser recolhidos para o estado (5\%) e os municípios (1\%), seu percentual era muito baixo e não incorporava as áreas da plataforma continental, representando um prejuízo significativo para o erário estadual e dos municípios petrolíferos.

\footnotetext{
${ }^{6}$ A resolução 3/54 do CNP reconhecia a exploração da petroquímica preferencialmente pela livre empresa nacional. A permissão para uma ação estatal na indústria petroquímica dava-se de maneira a subsidiar o desenvolvimento da empresa nacional.
} 
Adicione-se a isso o fato de o montante pago a título dos direitos de royalties dos estados e municípios petrolíferos ser relativamente baixo, pois o preço médio do barril do petróleo no mercado internacional era de U\$3,20. Somente a partir de 1973, quando foi deflagrado o primeiro grande choque do petróleo, é que o óleo atingiu preços elevados - U\$ 11,00 por barril - em virtude da decisão dos países membros da Organização dos Países Exportadores de Petróleo (OPEP) de reduzir em 25\% a oferta de petróleo aos países consumidores, como represália ao apoio militar, financeiro e político dado pelos EUA e outros países a Israel durante o período da guerra Árabe-israelense (SAMPSON, 1976); em 1979, quando houve o segundo grande choque do petróleo, o preço do produto tornou a se elevar bruscamente, atingindo o patamar de U\$ 40,00 o barril.

Ora, se se considerar que a partir dos anos 1940 os países exportadores de petróleo cobravam $50 \%$ de royalties para as companhias de petróleo produzirem petróleo em seus campos, e que, no Brasil, a Petrobras pagava apenas 5\% aos estados e $1 \%$ aos municípios, vê-se o quanto de recursos financeiros estes deixavam de arrecadar. Um exemplo disso é o caso do estado da Bahia - sem computar os valores devidos à exploração do gás natural - que produziu 10.106.269 de barris de óleo em 1957, no valor total de U\$32.340.060,80, e arrecadou apenas o equivalente a U\$849.323,11 quando deveria ser de U\$1.617.003,047, considerando-se a base de $5 \%$ da taxa de royalty (DANNEMANN, 1959); ; e, se fosse considerada a base de 50\%, teria arrecadado U\$ 16.170.030,4. ${ }^{9}$

Assim que a Petrobras iniciou o pagamento dos royalties ao estado da Bahia e aos municípios petrolíferos, em 1955, a parte referente aos campos da plataforma continental, na Baía de Todos os Santos, foi interrompida, em decorrência de uma interpretação equivocada da assessoria jurídica da Petrobras e do CNP, que considerou os recursos da plataforma continental como pertencentes exclusivamente à União, apesar da existência de pareceres jurídicos contrários. A questão foi solucionada favoravelmente ao estado da Bahia e aos municípios petrolíferos somente em 1961 (CAPITAL..., 1961).

\footnotetext{
${ }^{7}$ Em seus cálculos, a Petrobras utilizou uma taxa do dólar equivalente a $\mathrm{Cr} \$ 60,00$, enquanto que a taxa média anual oficial era de Cr\$ 74,23 por dólar.

${ }^{8}$ DANNEMANN (1959, p. 23) sugere que a diferença entre o valor arrecadado e o valor a que teria direito o estado da Bahia deve-se a: exclusão do royalty dos poços submarinos e possivelmente ao preço mais baixo pago pelo óleo nacional.

9 DANNEMANN (1959, p. 23) informa que, desde novembro de 1958, o Congresso Nacional Argentino aprovou um Projeto de Lei oriundo do Governo desse país, o qual nacionalizou "[...] as jazidas mas concede às províncias produtoras 50\% dos lucros líquidos da exploração do petróleo". Na Venezuela, desde os anos 1940, a taxa de royalty cobrada era também de 50\%, bem como na Arábia Saudita (SAMPSON, 1976).
} 
Um outro fator, também de grande importância, que contribuía para o descontentamento dos grupos sociais interessados direta e indiretamente nos negócios do petróleo, no Recôncavo Baiano, era a maneira essencialmente unilateral como a Petrobras agia.

Se os fatores anteriores já eram suficientes para indignar o Governo baiano e as forças sociais que Ihe emprestavam apoio, a ação de natureza microeconômica e unilateral orientadoras das ações do CNP durante as pesquisas e produção de óleo no Recôncavo Baiano, também implementadas pela Petrobras, coroava um forte sentimento de insatisfação e subjugação dessas forças sociais à companhia.

Nesse sentido, uma das queixas mais freqüentes nas discussões políticas, jurídicas e econômicas regionais a partir de 1956, foi o ato de o Governo federal declarar de utilidade pública para fins de desapropriação, de maneira genérica por cinco anos, todas as terras de nove municípios no Recôncavo Baiano,

[...] para fins de servidão legal ou de desapropriação total ou parcial em favor da Petróleo Brasileiro S. A. Petrobras, as áreas necessárias aos serviços de pesquisa, lavra e transportes de petróleo compreendidas nos imóveis situados nos Municípios de Salvador, São Francisco do Conde, Santo Amaro, São Sebastião do Passé, Camaçari, Mata de São João, Pojuca, Catú e Alagoinhas, no Estado da Bahia pertencentes a quem de direito (GOMES, 1959, p. 21).

Essa foi, sem dúvida, uma questão sui generis que descreve de maneira precisa como a Petrobras agia no Recôncavo Baiano, o que, além de tudo, acusa subliminarmente a mesma falta de um plano racional de operações da empresa, como também era usual com o CNP.

Esse fato, na opinião de Gomes (1959), promovia deliberadamente uma espécie de estagnação das atividades econômicas agrícolas e agroindustriais, pois forçava os proprietários rurais estabelecidos na aludida área a não executarem nenhum tipo de melhoramento nos estabelecimentos e também lhes impunha a dificuldade de negociar as propriedades, senão por preços vis, diante da declaração de desapropriação das terras para fins de utilidade pública.

Nessas condições, em forma de lamentação, conclui Gomes (1959, p. 22):

Encarado o problema à luz do decreto-lei n. 3.365 e do decreto n. 40.489, podese afirmar em remate, que toda uma região se encontra, até 4 de dezembro de 1961, em recesso econômico, com a sua atividade produtiva sacrificada e estrangulada a circulação de sua riqueza imobiliária, em conseqüência de se ter feito a declaração indiscriminada de utilidade pública de todas as terras, que serão desapropriadas apenas em parcela insignificante. 
Internamente, entre os funcionários e a direção da estatal, imperavam relações de dominação, que se materializavam por meio de mecanismos de coação utilizados como princípios normatizadores das relações empresa/empregados.

O arbítrio dos dirigentes da Petrobras em relação aos funcionários se manifestava como uma prática comum e de ocorrência no âmbito nacional, dada a formação militarizada dos seus quadros dirigentes, a qual era moldada na aplicação da doutrina da segurança nacional. Na mesma perspectiva se impunha o símbolo do nacional-desenvolvimentismo representado pela Petrobras, em nome do qual se cometia toda sorte de coações contra todos os funcionários que não estivessem atentos ao padrão de comportamento determinado pelo querer pessoal de algum chefe imediato. Nesse sentido, a vila operária, anexa à refinaria, além de cumprir a função para a qual fora construída favorecia também a coerção dos operários subalternos.

Quando a refinaria de Mataripe foi inaugurada, a sua direção resolveu construir uma vila operária anexa, para solucionar os problemas de interrupção do trabalho pelo motivo das dificuldades de transporte existentes à época, já que a maioria dos funcionários residia na cidade do Salvador. Na época, a vila de Candeias, localizada nas proximidades de Mataripe, não oferecia as condições de infra-estrutura necessárias às demandas dos funcionários, especialmente dos mais graduados - técnicos e engenheiros - cuja maior parte procedia de grandes cidades fora da Bahia (MATTOS et al, 2000).

A vila era dotada de cerca de duas centenas de casas para funcionários com família e de vários alojamentos coletivos para funcionários solteiros, escola primária, posto médico e maternidade, mercado, horta, farmácia, cinema e clube recreativo. Tudo estava à disposição do uso dos funcionários, sem qualquer ônus, exceto a aquisição de remédios na farmácia e alimentos no mercado, cujos preços eram subsidiados. Certamente esse conjunto de benefícios tornava-se vantajoso para os funcionários que tinham a possibilidade de ocupar uma habitação ou uma vaga nos alojamentos da vila.

Se por um lado, os funcionários dispunham da comodidade de residir próximo do local de trabalho e da vantagem da redução de custos financeiros, ocupando uma habitação na vila de Mataripe, por outro lado, pagavam o preço de perma- 
necer sob o controle social direto da empresa. Residir na vila de Mataripe também significava submeter-se ao trabalho compulsório e não-remunerado à noite e nos fins de semana, pelo motivo de estarem sempre em prontidão para o atendimento às emergências solicitadas pela empresa cujos funcionários estavam "ajudando a construir". Nesse sentido, o depoimento de um funcionário que residia na vila de Mataripe, há anos, sugere essa condição, segundo ressalta Mattos e outros (2000, p. 150): "Primeiro, ao afirmar que chegou a permanecer trinta e três dias na casa de força, morando perto da família e vendo sua mulher e filhos, todos passarem, sem poder ir até eles, porque não podia sair da refinaria."

A ocupação de uma casa ou alojamento na vila tornava o funcionário "refém" de seu chefe imediato, subordinado a tipos de relações que o impossibilitava fazer reclamações de melhorias salariais e/ou de condições de trabalho, segundo explica Oliveira Jr. (1996).

$\mathrm{Na}$ avaliação dos diretores e chefes da companhia e em especial da RLAM, esse fato, na maioria das vezes, equivalia, por parte dos funcionários, a aceitação sem crítica de jornadas de trabalho compulsórias e submissão a condições de trabalho insalubres e periculosas, contra uma remuneração insatisfatória, já que todos ali deveriam dedicar-se integralmente ao processo de construção do desenvolvimento da empresa e, por conseqüência, do país.

Nesse contexto, de 1954 a 1960, mesmo com a garantia expressa da lei, o surgimento de entidades profissionais para representar os interesses dos trabalhadores era desestimulado por parte dos dirigentes regionais da Petrobras, como esclarece Oliveira Jr. (1996), com base em entrevistas realizadas com antigos funcionários da empresa:

São vários os relatos dos nossos entrevistados em que transparece as dificuldades da construção da Associação, indo desde as tentativas de controle dos dirigentes sindicais à criação de dificuldades para a sindicalização; desde não proceder ao desconto para a entidade do valor da contribuição dos seus associados a pressionar os trabalhadores a dela não participarem, culminando, em $1960 \mathrm{com}$ a demissão de Osvaldo Marques e Mário Lima, presidente e secretário do novo sindicato - SINDIPETRO-Bahia (OLIVEIRA JR., 1996, p. 60-61).

A demissão sumária e injustificada de dois funcionários eleitos pela categoria dos petroleiros, para assumir a direção do sindicato no início de 1960, levou os trabalhadores a lutar pela readmissão dos seus líderes. A readmissão dos funcionários aconteceu ainda em 1960, após intensas negociações intermediadas inclusive pelo Governador do estado da Bahia e por parlamentares com mandato federal. 
Esse fato marcou o início de uma nova era na política de relações entre a empresa e os funcionários, forçada pela primeira vitória do sindicato da categoria recém-criado, com a readmissão de seus diretores. A partir desse evento, o sindicato ganhou força e confiança na categoria e no mesmo ano conseguiu realizar uma grande campanha por isonomia salarial entre os petroleiros da Bahia e os seus colegas da RPBC, no estado de São Paulo.

Após a primeira greve da categoria na Bahia, cuja paralisação das atividades durou três dias, a direção da refinaria decidiu negociar com o sindicato e cedeu, em parte, às solicitações dos grevistas. A direção da refinaria ofereceu $80 \%$ do percentual do pedido de aumento de salário pela categoria, no que os trabalhadores concordaram e retornaram às atividades, com um programa de aumento de produtividade para compensar os dias parados (OLIVEIRA JR., 1996).

O desfecho da greve favorável aos petroleiros baianos foi um fato isolado em que a Petrobras concordou com algum tipo de negociação. A condução administrativa da Petrobras sob uma política centralista e militarizada, escudada na doutrina da "Segurança Nacional", herdada dos tempos do CNP, tornava a empresa uma instituição temível para os demais agentes envolvidos direta e indiretamente nas atividades do petróleo no Recôncavo Baiano, além do que, para a empresa, o Recôncavo Baiano não passava de uma importante fonte de matérias-primas. Nessas condições, a Petrobras era um adversário vigoroso, cuja necessidade de enfrentamento, para dar algum resultado positivo, teria de ser implementada de maneira coletiva.

\section{A reação organizada dos agentes regionais às práticas unilaterais da Petrobras no Recôncavo Baiano}

Desde a época do CNP alguns agentes regionais reagiam de maneira isolada contra as ações unilaterais praticadas por esse órgão. Com a assunção das tarefas de pesquisa, lavra e industrialização do óleo e do gás natural pela Petrobras, logo no início, vários tipos de reações tiveram prosseguimento ainda de maneira individual.

A partir de 1958, com o intuito de proceder a uma reação organizada e unificada contra as ações de caráter unilateral e a falta de um programa de investimentos industriais da Petrobras na Bahia, os agentes sociais regionais, insatisfeitos com as ações da companhia, tomaram a iniciativa de se articular numa campanha de forte repercussão estadual. Essa campanha, dada sua amplitude política, atingiu a esfera política federal. O ápice dos descontentamentos teve seu efeito potencializado durante a realização da Conferência do Petróleo para 
Exame dos Justos Interesses da Bahia organizada pelo Jornal $A$ Tarde, nos dias 21,22 e 23 de janeiro de 1959. ${ }^{10}$

O conclave contou com a presença dos Governadores e vice-Governa-dores eleitos dos estados da Bahia e Sergipe (em Sergipe também eram desenvolvidas pesquisas de petróleo); toda a bancada baiana de parlamentares eleitos para a Câmara federal e o Senado; outros parlamentares federais convidados; representantes das forças armadas; representantes da Petrobras e do CNP; representantes da Associação Comercial da Bahia; demais representações das classes empresariais; representantes da Associação dos Petroleiros; representantes do órgão de Planejamento do Governo do estado da Bahia e intelectuais da Universidade da Bahia. Além disso, recebeu também o apoio formal da União dos Estudantes da Bahia (UEB).

É importante salientar que os interesses dos fazendeiros de cana, dos usineiros e dos banqueiros eram completamente diferentes dos funcionários da Petrobras, até porque a maioria dos petroleiros baianos, cujas condições de trabalho e remuneração eram superiores à sua história operária e social anterior, era formada por ex-empregados dos canaviais e usinas de açúcar, de onde eram recrutados pela Petrobras. Essa condição lhes colocava em campos opostos aos dos primeiros.

Não resta dúvida que a ideologia de "defesa dos interesses da Bahia" arrastava o apoio de várias categorias sociais regionais; mas o apoio dado à Conferência do Petróleo, pelos petroleiros, pode ser entendido como um sinal de gratidão e respeito ao Governador Juracy Magalhães (populista) recém-eleito e também como uma forma de representação de prestígio social e político dos dois mais importantes articuladores da diretoria do sindicato dos petroleiros, um dos quais, Mário Lima, o presidente do sindicato, alguns anos depois, seria eleito deputado federal nas eleições parlamentares em várias legislaturas. Portanto, esse apoio formal não se concretizava em apoio real dos petroleiros, inclusive porque nenhuma das recomendações da Carta do Petróleo relacionava qualquer interesse objetivo da categoria.

O temário da "Conferência do Petróleo" tratou apenas de questões referentes ao petróleo, versando sobre assuntos jurídicos, econômicos e sociológicos. Ao final das discussões foi elaborada e aprovada a "Carta do Petróleo" (Anexo), na qual foram publicados os principais e mais imediatos objetos de interesses dos agentes sociais regionais, em forma de recomendação ao Governo federal, ao Congresso Nacional, à própria Petrobras e ao CNP, para solução dos problemas ali levantados.

\footnotetext{
${ }^{10} \mathrm{O}$ jornal A Tarde pertencia ao seu fundador, Ernesto Simões Filho, que também foi parlamentar federal e exerceu vários cargos políticos, inclusive o de ministro da educação em 1951. Este diário, ao longo de sua história, além de ter obtido notoriedade regional como um veículo de comunicação, a exemplo dos demais, sempre funcionou como uma tribuna, a partir da qual o seu fundador, seus sucessores e seus aliados defendem seus interesses.
} 
Do exposto, tem-se que, no período entre 1954 e 1960, a Petrobras agia no Recôncavo Baiano segundo uma lógica eminentemente microeconômica desconsiderando quase completamente as demandas dos demais agentes sociais existentes na órbita de suas ações, os quais também tinham interesses diretos e/ou indiretos nas atividades vinculadas ao petróleo. Esse descrédito para com as demandas dos interlocutores regionais da Petrobras no Recôncavo Baiano constitui uma indicação evidente de que a estatal, até então não se havia tornado um agente social hegemônico no Recôncavo Baiano. Ao contrário, pela maneira como agia diante dos demais agentes sociais que nutriam interesses diretos e/ou indiretos pelas atividades do petróleo, a própria empresa fez surgir um grande movimento regional de reação aberta às suas ações na Bahia.

\section{A Petrobras inaugura sua lógica bifacial}

O princípio básico da ação da Petrobras era o de atingir suas metas econômicas concomitantemente com o desafio de dar respostas positivas à imperiosa necessidade de, muito brevemente, prover o mercado brasileiro com o volume suficiente de petróleo, essencial ao progresso econômico do país. Nessa perspectiva, a Petrobras se apresentava aos seus interlocutores, concorrentes e/ou aliados, segundo a conveniência exigida no momento, ora com um argumento de uma empresa pública, ora com um argumento de almejar lucros, com sua face privada.

Segundo Abranches (1980) e Contreras (1994), a maneira ambígua com a qual as empresas estatais agem permite-Ihes realizar tanto objetivos macroeconômicos, os de ordem mais social, voltados para a superação do atraso social e econômico regional/nacional, quanto os microeconômicos, comandados por suas necessidades de atingir as melhores taxas de lucro.

Abranches (1980) esclarece que a bifacialidade das ações dessas empresas constitui uma contradição insolúvel, própria da inserção do Estado na economia capitalista. Contudo, ela pode ser disciplinada com a implementação de mecanismos de controle político externo, de maneira sistemática, por parte do Estado sem o comprometimento de sua autonomia gerencial.

Ainda segundo o mesmo autor, a bifacialidade é uma característica inerente aos empreendimentos estatais existentes não só no Brasil e em muitos países da periferia da economia capitalista, como também em vários países que fazem parte do centro da economia capitalista mundial, a exemplo da França, Itália, Espanha e Inglaterra, dentre outros, em que o Estado age por meio de empresas comerciais e industriais diretamente e/ou em associação com grupos privados, como também identificaram Anastassopulos; Blanc; Dussage (1985). 
Para Abranches (1980), a participação do Estado no processo de acumulação capitalista é determinada, principalmente, pelo estágio do desenvolvimento das estruturas produtivas nacionais, pelo grau de heterogeneidade das economias nacionais e também pela dinâmica da política dos interesses sociais nos distintos países.

Nessa linha de raciocínio, a autonomia conquistada por algumas empresas estatais deve-se ao próprio processo de criação das distintas empresas, seus objetivos e mecanismos de inserção na economia nacional, bem como aos procedimentos de regulação e financiamento a elas atribuídos, constituindo uma base social, política e econômica para o desenvolvimento do capitalismo na escala do país, diante da fragilidade financeira e tecnológica da empresa privada nacional (ABRANCHES, 1977; DAIN, 1977).

No Brasil, por exemplo, a autonomia com que a burocracia da Petrobras age reflete a natureza da própria constituição da empresa, gerada no calor dos debates em que a defesa do desenvolvimento nacional surgiu como projeto vencedor e, com isso, logo no início, adquiriu autonomia política. Num segundo momento, foi o próprio Governo (1964-1967) quem Ihe outorgou a autonomia financeira ao Ihe franquear a lucrativa exploração da distribuição dos derivados de petróleo, por meio de uma rede de postos de combustíveis e serviços; pela eliminação dos subsídios ao consumo de derivados do petróleo; pela reformulação da lei do Imposto Único sobre Combustíveis Líquidos (Decreto-Lei no 61/66); pelo monopólio da importação nacional de petróleo e sua vinculação às exportações nacionais de produtos industrializados, dentre outras medidas (MARINHO JR., 1989; CARVALHO, 1977).

A partir de 1970, a própria conjuntura política, econômica, interna e externa favorável à estatal foi que conduziu a tecnoburocracia da estatal a tomar a iniciativa de ampliar exponencialmente sua autonomia, com a consolidação de sua estrutura organizacional conglomerada.

Isso posto, pode-se identificar no Recôncavo Baiano várias oportunidades em que a Petrobras fez uso do recurso da bifacialidade.

Esta empresa, ao empreender suas ações na região segundo uma lógica que não contemplava as demandas dos seus interlocutores regionais e industrialmente limitada, gerava entre esses agentes, na opinião pública e entre os políticos uma forte reação em protesto à política de agressividade microeconômica, quando se esperava que a companhia desenvolvesse ações fundamentalmente ligadas à criação de economias externas, como compreende Abranches (1980).

Sem dúvida, é flagrante a ação da Petrobras no processo de acumulação de capital, vis à vis o forte apelo das condições de mercado como determinante para a localização dos empreendimentos da organização, próximos às áreas de maior con- 
sumo de derivados de petróleo, como fica evidente nas palavras de Fonseca (1959) já citadas anteriormente. Esse fato permitia à empresa maximizar a geração de lucros e dividendos para os seus acionistas, conforme se depreende dos dados relativos aos resultados financeiros globais da empresa, cujo lucro líquido sempre se manteve de maneira crescente (Tabela 10).

Tabela 10 - Receitas, despesas e lucro líquido da Petrobras - 1955/1962

\begin{tabular}{l|r|r|r|r|r|r}
\hline \multirow{2}{*}{ Ano } & \multicolumn{2}{|c|}{ Receita Total } & \multicolumn{2}{c|}{ Despesa Total } & \multicolumn{2}{c}{ Lucro Líquido } \\
\cline { 2 - 7 } & \multicolumn{1}{|c|}{ Cr\$ (1.000) } & U\$ $(1.000)$ & Cr\$ (1.000) & U\$ (1.000) & Cr\$ $(1.000)$ & U\$ (1.000) \\
\hline 1955 & $4.773 .418,0$ & $66.826,5$ & $4.602 .439,6$ & $64.432,9$ & $170.978,5$ & $2.393,7$ \\
1956 & $9.723 .196,0$ & $138.113,6$ & $7.868 .959,0$ & $111.775,0$ & $1.854 .237,0$ & $26.338,6$ \\
1957 & $14.763 .197,7$ & $198.884,5$ & $10.851 .602,4$ & $146.188,9$ & $3.911 .595,3$ & $52.695,6$ \\
1958 & $23.204 .784,3$ & $182.198,4$ & $16.640 .263,6$ & $130.655,3$ & $6.564 .520,7$ & $51.543,0$ \\
1959 & $38.723 .743,7$ & $255.855,6$ & $26.863 .532,5$ & $177.492,8$ & $11.860 .211,2$ & $78.362,8$ \\
1960 & $57.305 .390,8$ & $307.316,9$ & $43.108 .725,9$ & $231.183,2$ & $14.196 .664,9$ & $76.133,8$ \\
1961 & $135.378 .715,7$ & $501.774,3$ & $104.681 .043,0$ & $387.995,0$ & $30.697 .672,7$ & $113.779,4$ \\
1962 & $238.293 .040,4$ & $614.157,3$ & $194.607 .156,9$ & $501.564,8$ & $43.685 .883,4$ & $112.592,5$ \\
\hline
\end{tabular}

FONTE: Organizada por Brito (2004), com base em matéria da Revista Petrobras (1953-1963 DEZ..., 1963). Não foram divulgados os dados para 1954; não se teve acesso aos dados posteriores a 1962.

Se não bastassem as ações, as palavras do Superintendente Regional da Petrobras na Bahia são esclarecedoras da bifacialidade da empresa ao utilizar o recurso da lógica privada das organizações econômicas capitalistas, na tentativa de contestar a acusação de que o estado da Bahia não se beneficiava da existência de petróleo em seu subsolo: "Antes de analisar esta outra afirmação, devemos ter em mente que a Petrobras é uma companhia de capital e de âmbito nacional. É sob este aspecto, também, que ela deve encarar os problemas que lhe são afetos" (BARROSO, 1959, p. 53).

No entanto, quando a questão se referia às melhorias dos salários e das condições de trabalho dos seus funcionários, seus diretores alegavam a natureza pública da empresa que não poderia assumir grandes encargos com salários, pois a empresa era do Governo e estava em fase de desenvolvimento, por isso "[...] a PETROBRAS não tinha condições de promover a equiparação com o pessoal de São Paulo, [...]" (PINTO DE AGUIAR, 1980 apud OLIVEIRA JR., 1996, p. 82-83).

A bifacialidade passaria a ser um recurso comum operado pela empresa, com vistas a tentar arrefecer a imagem negativa que a ela era atribuída por seus interlocutores na Bahia. Nesse sentido, a direção regional da Petrobras buscou dar relevo aos investimentos realizados no Recôncavo Baiano. Nesses investimentos pode-se identificar alguns elementos fortes que, no bojo de seu processo de inserção e fixação no Recôncavo Baiano, desde sua fase inicial, marcaram a cena com um conjunto de ações simultâneas, que "pavimentaram o caminho" para a realização dos interesses diretos da companhia e que, por consequência, 
atingiu indiretamente resultados econômicos e sociais importantes em um meio de forte estagnação econômica.

Trata-se dos principais investimentos realizados pela estatal que, no Recôncavo Baiano, se materializaram em três frentes diferentes e concomitantes, a saber: a instalação de uma rede de estradas, a grande oferta monetária em circulação e o desencadeamento de um rápido processo de urbanização.

\section{A implantação da rede de estradas}

Nos dias atuais tem-se apenas uma idéia aproximada das implicações da construção de uma rede de estradas de rodagem asfaltada ligando escritórios, fábricas, depósitos, cidades etc. às fontes de recursos para uma grande empresa, que lida com um tipo de produto (petróleo), de importância econômica, política e estratégica para os grandes grupos econômicos e Estados-nação. Essa importância aumenta, principalmente, num período pós-Guerra, em que o controle do acesso às fontes dessa matéria-prima para esses agentes tornou-se condição indispensável.

Até o início da década de 1950, por terra, o meio de transporte de carga mais utilizado no Recôncavo Baiano era o carro-de-boi, que vencia os obstáculos do terreno. A maior parte das terras desta região era formada de solos de massapê (vertissolo), originados da alteração físico-química da rocha gnaisse. Bastante argiloso, o solo se torna lamacento durante os períodos de abundância de chuvas. Essa condição natural constituía grande dificuldade para as operações de transporte da Petrobras. Ao longo dos anos 1950, a demanda de petróleo crescia exponencialmente e requeria ações rápidas e integradas da empresa no Recôncavo Baiano, com o fim de equacionar os problemas de transporte.

A precariedade das estradas de rodagem nesta região dificultava, quando não impedia, os trabalhos da empresa durante os períodos de grande concentração pluviométrica - cerca de $2.000 \mathrm{~mm}$ anuais - que se estende do mês de abril a junho. As operações de transporte da Petrobras requeriam o deslocamento de grande quantidade de material, máquinas, equipamentos, pessoal para trabalho nos campos e ainda parte do óleo cujo transporte era feito por caminhão e trem, tudo de maneira contínua.

No Recôncavo Baiano, a partir de fins dos anos 1950, houve uma mudança substancial na infra-estrutura de transporte terrestre, com a implantação e pavimentação asfáltica de uma parte da malha rodoviária estadual. 
Com exceção da rodovia federal BR 324, Salvador-Feira de Santana, cujo asfaltamento foi concluído em 1959, essa novidade somente existia na parte Nordeste do Recôncavo Baiano, no sentido Salvador/Aracaju, a partir da cidade de Salvador, em decorrência da descoberta de grandes campos de petróleo e de gás natural em vários municípios localizados nessa área. Para superar as dificuldades de transporte em sua área de operações, no Recôncavo Baiano, a Petrobras passou a investir volumosos recursos da ordem de $\mathrm{Cr} \$ 300.000 .000,00$ (U\$ 2.355.527,64), em convênio com o Governo do estado da Bahia, no financiamento do programa rodoviário estadual.

O montante de recursos envolvidos na execução das obras rodoviárias formava uma quantia superior à quota investida pela empresa que era de $\mathrm{Cr} \$$ $135.000 .000,00$ (U\$ 1.059.987,44), a partir de 1956. Os recursos da quota-parte do Governo estadual para execução dessa parte do programa rodoviário eram provenientes da taxa de $1 \%$ de royalty devida aos municípios petrolíferos e que até 1956 era paga por intermédio do Governo estadual. Conforme explica Barroso (1959), por conta desse convênio, durante o período de 1956 a 1960, foram abertas várias estradas asfaltadas de acesso aos campos de petróleo em várias partes do Recôncavo Baiano.

Apesar de dispor de uma refinaria em funcionamento desde 1950 e também de uma grande oferta de óleo, as estradas na Bahia somente começaram a ser pavimentadas a partir de 1956, com o asfalto importado da RPBC. O asfalto, procedente inicialmente da RPBC e depois, também, da Refinaria de Duque de Caxias (Reduc), era desembarcado no Terminal Marítimo de Madre de Deus (Temadre), onde tinha uma base de suprimentos do Departamento Nacional de Estradas e Rodagem (DNER) e depois distribuído entre as firmas empreiteiras para a pavimentação da rodovia BR-116, Rio/Bahia, que foi inaugurada em 1963, e também para a pavimentação das demais estradas no estado da Bahia: a rodovia BR 101, inaugurada em 1972, a rodovia BR-324, em 1959, e parte da malha rodoviária estadual.

Deve-se observar que as primeiras estradas de rodagem asfaltadas no Recôncavo Baiano privilegiaram as áreas de interesse direto da Petrobras. Dessa maneira, tornouse efetivamente possivel uma articulação mais flexível, internamente, na específica área, organizada em torno das atividades da companhia.

Com a abertura das estradas foi permitido um amplo acesso rodoviário entre a capital e as áreas produtoras de petróleo. Com isso, a empresa resolveu seus problemas de transporte de máquinas, equipamentos, ferramentas, mantimentos, parte do petróleo e operários das cidades e acampamentos para os campos de produção, para a refinaria e vice-versa. Da mesma maneira, tornava-Ihe acessivel a força de trabalho em abundância, já que novas fronteiras urbanas foram abertas no Recôncavo Baiano por meio de ônibus, caminhões e de automóveis. 
Durante a segunda metade dos anos 1950 os campos de petróleo em plena produção já alcançavam os municípios de Catu, Pojuca, Alagoinhas e também Entre Rios, este localizado mais ao Norte. A mesma celeridade era empregada na descoberta de novos campos de petróleo que se disseminavam nos municípios localizados nas áreas mais extremas ao Norte da Bacia Sedimentar do Recôncavo, em direção ao estado de Sergipe. Até esse momento o município de Entre Rios, com um campo produtor de óleo, era a localidade mais distante da capital, cerca de 130 km (Figura 5).

FIGURA 5 - RPBA: Distribuição dos campos de petróleo e de gás natural - 1960

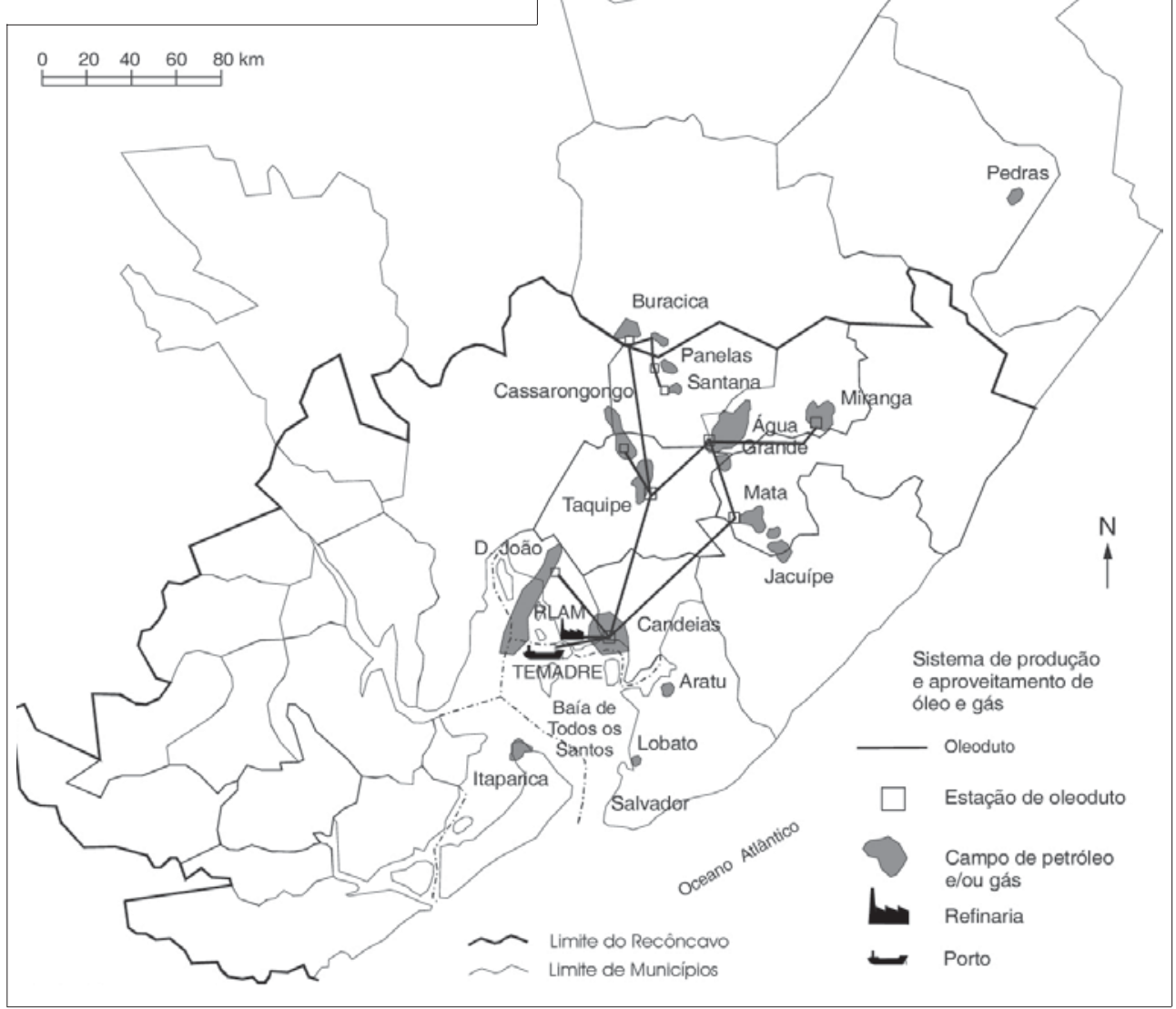

FONTE: Organizado por Brito (2004), com base em Fernandes (1958) e RBPA (1975).

A rede de estradas asfaltadas aberta de maneira seletiva em algumas partes do Recôncavo Baiano, no período de 1950/1960, foi suficiente para, num 
primeiro momento, instrumentalizar o território em torno das atividades petrolíferas, para atender aos objetivos mais imediatos da Petrobras.

Contudo, essa rede de estradas construída pela Petrobras no Recôncavo Baiano não obedecia a outros critérios de integração espacial que não fossem o da própria companhia, ainda que essa infra-estrutura pudesse ser utilizada coletivamente como um equipamento público, como de fato passou a ser.

\section{A grande oferta monetária em circulação}

Associado à abertura de estradas asfaltadas, um outro fato de substancial importância na dinamização das ações iniciais da Petrobras no Recôncavo Baiano foi, sem dúvida, a massa de recursos financeiros gerada pelas atividades da companhia na Região de Produção da Bahia (RPBA) e parte dela reinvestida nela própria.

Como ficou demonstrado na Tabela 10, a magnitude dos recursos gerados anualmente pela Petrobras era tão importante que a empresa programou um investimento, em suas atividades no Recôncavo Baiano, igual à receita total orçada do próprio Governo da Bahia para o exercício de 1959, que foi da ordem de Cr\$3 bilhões, ou seja, quase U\$ 20 milhões (BARROSO, 1959). O extraordinário desempenho econômico da companhia era sustentado pelo aumento exponencial da produção de petróleo que ocorria ano após ano, repercutindo, com isso, na possibilidade de realizar vultosos investimentos em suas atividades.

Até 1956, os recursos devidos aos municípios pela Petrobras eram arrecadados e repassados pelo Governo estadual, mas, a partir de 1957, a empresa passou a pagar os impostos e taxas diretamente aos municípios. Esse fato passou a gerar um incremento de receita anual bastante importante para os municípios petrolíferos, ainda que com o percentual de $1 \%$ sobre o total das matérias-primas extraídas de seus respectivos subsolos.

A Tabela 11 apresenta uma idéia aproximada do montante de recursos exclusivamente derivados da produção de petróleo pagos a alguns dos municípios petrolíferos durante o período em discussão.

Quanto ao Governo do estado, os pagamentos devidos pela Petrobras eram a cada ano sempre mais significativos como se pode inferir a partir da declaração do Superintendente Regional da Petrobras:

Nos três primeiros anos esta importância foi de Cr\$36.916.208,50 [U\$ 524.377,96]; em 1957, foi de Cr\$ 43.106.787,00 [U\$ 580.719,21] e no primeiro semestre deste ano já é de Cr\$40.356.208,40 [U\$550.937,99] devendo, no mínimo duplicar até dezembro (BARROSO, 1959, p. 54). 
Tabela 11- Recôncavo Baiano: arrecadação de taxas de royalty e impostos de vendas e consignações, em alguns municípios petrolíferos - 1956/57

\begin{tabular}{l|c|c|c|c|c|c|c}
\hline \multirow{2}{*}{ Municípios } & \multicolumn{7}{c}{ Ano } \\
\cline { 2 - 9 } & \multicolumn{2}{|c|}{1956} & \multicolumn{2}{c}{1957} & \multicolumn{3}{c}{ Aumento 1956/1957 } \\
\cline { 2 - 9 } & $\begin{array}{c}\text { Cr\$ } \\
(1.000)\end{array}$ & $\begin{array}{c}\text { U\$ } \\
(1.000)\end{array}$ & $\begin{array}{c}\text { Cr\$ } \\
(1.000)\end{array}$ & $\begin{array}{c}\text { U\$ } \\
(1.000)\end{array}$ & $\begin{array}{c}\text { Cr\$ } \\
(1.000)\end{array}$ & $\begin{array}{c}\text { U\$ } \\
(1.000)\end{array}$ & $\%$ \\
\hline Pojuca & 945,69 & 13,43 & $4.117,79$ & 55,47 & $3.172,10$ & 42,04 & 435,4 \\
Mata de São João & $1.104,56$ & 15,68 & $2.000,94$ & 26,94 & 896,38 & 11,26 & 181,2 \\
Catu & $2.774,36$ & 39,4 & $4.796,16$ & 64,61 & $2.021,80$ & 25,21 & 172,8 \\
São Francisco do Conde & $1.752,19$ & 24,88 & $2.370,23$ & 31,92 & 618,04 & 7,04 & 135,3 \\
TOTAL & $6.576,80$ & 93,39 & $13.285,12$ & 178,94 & $6.708,32$ & 85,55 & 202,0 \\
\hline
\end{tabular}

FONTE: Organizada por Brito (2004), com base em Barroso (1959).

Enfim, a massa monetária em circulação na RPBA era de tal monta que os valores pagos referiam-se à ordem de milhões de cruzeiros em fins dos anos 1950, como afirma ainda Barroso, referindo-se ao ano de 1958:

No ano findo, por exemplo, o oleoduto ligando Catu-Mata-Pojuca à Mataripe e à Madre de Deus foi construído desta forma [obras extras]. Foi uma obra, que nos custou cerca de 172 milhões de cruzeiros [U\$1.350.502,21].

[...] êste ano até outubro pagamos 337 milhões de cruzeiros [U\$2.699.887,84] por várias obras que foram executadas por empreiteiras. Nos dez primeiros meses deste ano pagamos de salário ao pessoal nacional o total de $\mathrm{Cr} \$ 290$ milhões [U\$ 2.323.345,62]; compramos na praça de Salvador por dia útil uma média de Cr\$ 750.000,00 [U\$ 5.888,82] (BARROSO, 1959, p. 54-55).

Como a Petrobras não era apenas uma grande empresa estatal, mas também detinha o monopólio do petróleo e do gás natural, a companhia arcava com despesas bastante vultosas, pagamentos diversos e, também, com a folha de salários de seus milhares de funcionários diretos. A esse respeito, Azevedo, T. (1959a, p. 14), destaca:

O montante de salários pagos e, em grande parte, lançados em circulação é extraordinário para o meio. A folha de pagamento do "campo" de Candeias é da ordem de Cr\$ 4 milhões mensais [U\$31.407,00]; a da Refinaria Landulpho Alves, de Cr\$ 8,5 milhões [U\$ 66.739,94]; a da ampliação da Refinaria, de Cr\$ 11 [U\$ 86.369,34]; a do "campo" de Catú, Cr\$ 6,8 milhões [U\$ 53.391,95]. O total de todos os salários na área em exploração e pesquisa somará mais de Cr\$30 miIhões [U\$ 235, 552,76] mensais, sem computar os salários de técnicos de alto padrão, que recebem na Cidade do Salvador. Quanto às empresas empreiteiras [...] essas organizações receberam, somente nas obras de ampliação da refinaria, 
em novembro último, cerca de Cr\$14 milhões [U\$ 109.924,62] que devem incluir boa parte de salários pagos no local.

Segundo informações de Azevedo, T. (1959a), em sua área de operações, na RPBA, a Petrobras reunia 7.553 funcionários diretos no fim dos anos 1950 e, possivelmente, uma parte ainda maior de funcionários subcontratados. Os funcionários administrativos e técnicos de nível superior e médio eram os melhor remunerados, eles percebiam salários "[...] muito acima dos proventos da maioria de proprietários rurais e urbanos, gerentes e funcionários de usinas, funcionários públicos e outros [...]" (AZEVEDO, T., 1959a, p. 14). Contudo, para os operários de campo, a maior parte dos funcionários da empresa, os salários situavam-se entre $\mathrm{Cr} \$ 5.500,00$ e $\mathrm{Cr} \$ 6.450,00$ [U\$ 36,34 e U\$ 42,62], sendo que o valor do salário mínimo determinado pelo Governo federal para o município de Salvador, em 1959, era de Cr\$4.500,00 [U\$29,72]. Para a mesma época, segundo dados do Anuário Estatístico do Brasil (AEB), o valor do salário mínimo era de $\mathrm{Cr} \$ 4.000,00$ [U\$ 25,43], em: Catu, Itaparica, Mata de São João, Pojuca, Santo Amaro, São Francisco do Conde e São Sebastião do Passé, incluindo Feira de Santana e Alagoinhas; e de Cr\$3.600,00 [U\$ 23,79], em: Cachoeira, Camaçari, Conceição do Almeida, Cruz das Almas, Maragogipe, Muritiba, Nazaré, Santo Antônio de Jesus, Sapeaçu, São Félix, São Felipe, São Gonçalo dos Campos e Conceição da Feira.

Certamente os salários dos "petroleiros" não eram tão elevados, pois sequer atingiam dois salários mínimos. Há de se considerar que o período era de inflação alta, entretanto, comparando-se os salários dos "petroleiros" com a média salarial regional, os empregados da Petrobras apareciam como a categoria de trabaIhadores baianos mais bem pagos. Contra a política da Petrobras de pagar meIhores salários aos seus funcionários, sempre se colocavam os usineiros e fazendeiros, com a finalidade de manterem sempre muito baixo o nível salarial regional, para continuar obtendo lucros elevadíssimos e manter a massa de trabalhadores do Recôncavo Baiano sem a possibilidade de opção de escolha de trabalho.

Essa importante novidade, representada pelo grande volume de dinheiro que entrava mensalmente em circulação nas cidades petrolíferas, e nas outras que se situavam em suas adjacências e/ou ficavam em sua órbita, dava partida a uma nova dinâmica econômica e social no velho Recôncavo. Essa mudança se verificava por meio dos salários dos "petroleiros", de uma massa igualmente grande de operários, de firmas que prestavam serviços à Petrobras e de pagamentos diversos da própria empresa, contra a aquisição de bens e/ou serviços.

Nesse sentido, a perspectiva de almejar salários melhores e um emprego de prestígio, como o era na Petrobras, fazia com que uma parte importante da população em idade de trabalho e que habitava as áreas do entorno das atividades 
petrolíferas se aproximasse da empresa, seja para trabalhar diretamente nela ou em firmas subcontratadas; seja ainda para fornecer mercadorias e serviços à própria empresa, às firmas contratadas e também aos seus funcionários. Essa nova dinâmica associada a outros fatores ligados principalmente às operações da companhia no Recôncavo Baiano, potencializou o início do processo de crescimento urbano em ritmo acelerado e de seus possíveis desdobramentos na RPBA.

\section{O desencadeamento de um rápido processo de cresci- mento urbano}

A infra-estrutura construída pela Petrobras na RPBA, entre 1954 e 1960, para dar prosseguimento às suas operações de pesquisa, produção, transporte e processamento do óleo e do gás natural imprimiu, na referida área e em suas adjacências, a emergência de uma nova forma de organização e de reprodução do espaço geográfico.

Nesse período, a base construída para servir às operações da companhia envolveu várias obras de construção civil e montagem industrial de grande expressão, executadas simultaneamente e distribuídas por distintas partes da RPBA, conforme está sumarizado no Quadro 1.

Quadro 1 - Principais obras construídas para utilização pela Petrobras na RPBA - 1955/1960

\begin{tabular}{|c|c|}
\hline Ano & Obras construídas \\
\hline 1955 & - 50 km de oleoduto para conectar os campos de Miranga, Água Grande e Mata; \\
\hline 1956 & $\begin{array}{l}\text { - } 100 \text { km de oleoduto para conectar os campos de Panelas, Buracica, Taquipe e } \\
\text { Candeias até a refinaria e ao Temadre; } \\
\text { - Temadre; } \\
\text { - construção de rodovias; }\end{array}$ \\
\hline 1957 & $\begin{array}{l}\text { - duplicação da RLAM (de } 5 \text { mil bpd, para } 10 \text { mil bpd); - } 65 \text { km de oleoduto para o } \\
\text { Temadre; - construção de rodovias; }\end{array}$ \\
\hline 1958 & - ampliação da RLAM (de 10 mil bpd para 42,5 mil bpd); - construção de rodovias; \\
\hline 1959 & - ampliação do Temadre; - ampliação da RLAM (42,5 mil bpd); \\
\hline 1960 & - conclusão da ampliação da RLAM (42,5 mil bpd); - construção de rodovias. \\
\hline
\end{tabular}

FONTE: Organizado por Brito (2004), com base em 1953-1963: DEZ... (1963), RPBA (1975).

Como conseqüência imediata dessas transformações no espaço geográfico, ocorreu um importante incremento na população residente nas sedes dos municípios petrolíferos, reforçado inclusive por um grande número de imigrantes que se instalou nesses municípios entre 1950 e 1960. 
No Recôncavo Baiano, a população urbana aumentou, mas o incremento demográfico foi maior nas sedes dos municípios. Para os municípios localizados na RPBA, as taxas de incremento da população nas cidades foram as mais elevadas. Nesse sentido, o município de Candeias, emancipado de Salvador em 1958 tem grande destaque: até 1958, a localidade de Candeias era um subdistrito do município de Salvador, com uma população total de 3.607 habitantes distribuídos entre o povoado e a parte rural; em 1960, após a emancipação política, a população total do novo município passou para 18.484 habitantes, com 12,5 mil pessoas residindo na sede e quase seis mil na zona rural, representando um aumento total de mais de 500\% na população em menos de dois anos.

Dos 12 municípios do Recôncavo Baiano, cujas respectivas cidades registraram aumento de população acima de 50\%, apenas três: Conceição do Almeida $(94,6 \%)$, Cruz das Almas $(80,4 \%)$ e Sapeaçu $(74,8 \%)$ não se localizam na RPBA; os outros nove municípios tiveram aumento entre $60 \%$ e $150 \%$ (Tabela 12).

Para os municípios petrolíferos, o fenômeno que aparecia como fator de atração da população era a presença da Petrobras, enquanto para os outros três municípios citados, as elevadas taxas de crescimento urbano deveram-se, principalmente, ao excedente demográfico no meio rural, em conseqüência da crise da fumicultura no estado da Bahia, iniciada em fins dos anos 1950 e que liquidaria a incipiente indústria baiana do fumo nas décadas seguintes.

Apesar de nos municípios fumageiros a crise da fumicultura ainda não ter se apresentado de maneira aguda durante os anos 1950, nos municípios canavieiros, a estagnação econômica já era patente e, de 19 usinas de açúcar existentes em 1942, dez já haviam encerrado suas atividades por volta de 1960.

O encerramento das atividades de um maior número de usinas não se concretizava de imediato, em decorrência de os usineiros prosseguirem firmemente em suas ações de se apoiarem nos seguintes expedientes: o apoio fiscal dos Governos estadual e federal; o apoio dos Governos estadual e federal para legitimar a elevação artificial dos preços do açúcar monopolizado pela firma S/A Magalhães; o esbulho, até as últimas conseqüências, de outros usineiros menores, de fazendeiros de cana independentes e dos operários e lavradores. Isso concorriam para a obtenção de resultados financeiros amortizadores do processo de liquidação das formas de relações sociais e de produção anacrônicas presentes até então no Recôncavo Baiano (LEFEBVRE, 1973). 
Tabela 12 - Recôncavo Baiano: população rural e urbana - 1950/1960

\begin{tabular}{|c|c|c|c|c|c|c|c|c|}
\hline \multirow{4}{*}{ Municípios } & \multicolumn{8}{|c|}{ População } \\
\hline & \multicolumn{3}{|c|}{1950} & \multicolumn{3}{|c|}{1960} & \multirow{2}{*}{\multicolumn{2}{|c|}{$\begin{array}{l}\text { 1950/60 } \\
\text { Na Sede }\end{array}$}} \\
\hline & \multirow{2}{*}{ Rural } & \multicolumn{2}{|c|}{ Urbana } & \multirow{2}{*}{ Rural } & \multicolumn{2}{|c|}{ Urbana } & & \\
\hline & & Total & Na Sede & & Total & Na Sede & Total & $\%$ \\
\hline Catu & 12.297 & 4.140 & 3.558 & 12.035 & 9.686 & 8.883 & 5.325 & 149,7 \\
\hline São Francisco do Conde & 8.573 & 2.504 & 1.453 & 14.525 & 3.930 & 3.005 & 1.552 & 106,8 \\
\hline Camaçari & 9.360 & 4.440 & 2.715 & 11.818 & 10.031 & 5.342 & 2.627 & 96,8 \\
\hline Conceição do Almeida & 2.868 & 2.539 & 2.026 & 19.802 & 4.566 & 3.942 & 1.916 & 94,6 \\
\hline Cruz das Almas & 14.064 & 6.758 & 6.758 & 12.006 & 12.190 & 12.190 & 5.432 & 80,4 \\
\hline (1) Alagoinhas & 27.411 & 24.596 & 21.283 & 32.851 & 42.571 & 38.246 & 16.963 & 79,7 \\
\hline (2) Sapeaçu & 9.300 & 2.154 & 1.206 & 10.239 & 2.924 & 2.108 & 902 & 74,8 \\
\hline Mata de São João & 10.111 & 7.540 & 4.766 & 12.472 & 10.921 & 8.117 & 3.351 & 70,3 \\
\hline Itaparica & 12.799 & 8.634 & 2.603 & 13.647 & 11.629 & 4.308 & 1.705 & 65,5 \\
\hline São Sebastião do Passé & 12.501 & 5.079 & 2.544 & 15.663 & 8.300 & 4.140 & 1.596 & 62,7 \\
\hline Salvador & 27.813 & 389.422 & 389.422 & 17.143 & 638.592 & 630.878 & 241.456 & 62,0 \\
\hline Pojuca & 4.217 & 2.694 & 2.534 & 4.358 & 4.217 & 4.054 & 1.520 & 60,0 \\
\hline São Felipe & 23.502 & 1.841 & 1.080 & 22.345 & 2.336 & 1.579 & 499 & 46,2 \\
\hline S. Gonçalo dos Campos & 25.207 & 5.596 & 3.771 & 26.091 & 7.343 & 5.391 & 1.620 & 43,0 \\
\hline Santo Amaro & 55.808 & 29.931 & 12.258 & 53.658 & 46.563 & 17.226 & 4.968 & 40,5 \\
\hline Conceição da Feira & 8.286 & 2.246 & 2.246 & 8.361 & 3.057 & 3.057 & 811 & 36,1 \\
\hline Nazaré & 11.504 & 12.541 & 11.205 & 12.281 & 15.977 & 14.644 & 3.439 & 30,7 \\
\hline Santo Antônio de Jesus & 17.829 & 11.839 & 11.417 & 18.352 & 15.486 & 14.902 & 3.485 & 30,5 \\
\hline Muritiba & 22.757 & 8.848 & 7.452 & 24.457 & 13.589 & 9.679 & 2.227 & 29,9 \\
\hline Maragogipe & 21.680 & 15.188 & 9.744 & 20.420 & 19.322 & 12.575 & 2.831 & 29,1 \\
\hline Cachoeira & 14.163 & 12.816 & 10.825 & 14.953 & 13.916 & 11.415 & 590 & 5,5 \\
\hline Aratuipe & 4.060 & 2.291 & 1.432 & 4.212 & 2.646 & 1.508 & 76 & 5,3 \\
\hline São Félix & 8.814 & 5.987 & 5.872 & 8.807 & 6.059 & 5.993 & 121 & 2,1 \\
\hline Jaguaripe & 7.425 & 2.978 & 1.006 & 8.448 & 3.410 & 941 & -65 & $-6,5$ \\
\hline (2) Candeias & $\ldots$ & $\ldots$ & $\ldots$ & 5.984 & 12.500 & 12.500 & & \\
\hline
\end{tabular}

FONTE: Organizada por Brito (2004), com base em IBGE (1950, 1961).

NOTAS: ... Dado não divulgado; - Dado igual a zero, não resultante de arredondamento. (*) M unicípio petrolífero localizado fora do Recôncavo;(**) Município emancipado na década de 1950.

Se nenhuma novidade se apresentava como alternativa à crise, nessa parte do Recôncavo Baiano, essa parte do espaço geográfico tornava-se, predominantemente, um centro de expulsão de população. Dessa maneira, o incremento demográfico nas cidades ali localizadas ocorria com percentuais mais baixos que na parte da RPBA.

Durante o lapso de tempo em análise, no que se refere à evolução econômica e social do Recôncavo Baiano, é sugestivo destacar que, entre os municípios açucareiros, Santo Amaro é o mais importante e também o que mais perdeu população entre 1950 e 1960. No Recôncavo Baiano, somente esse município aparece numa lista dos 27 municípios baianos, que mais perderam população para o estado de São Paulo em 1952; nesse ano emigraram de Santo Amaro, 1.731 pessoas para São Paulo, conforme evidencia o estudo de Borges (1958). 
Ao longo da década de 1950, no Recôncavo Baiano, a divisão espacial da produção já se encontrava organizada predominantemente em torno das atividades da cana-de-açúcar e do fumo de um lado, e as atividades petrolíferas e de criação de gado do outro. A economia do Recôncavo Baiano ainda estava imersa em seu longo processo de estagnação estrutural e, subjacente a isso, permanecia, em 1960, uma estrutura fundiária fortemente concentrada, com $68 \%$ das terras formando os grandes estabelecimentos, os quais totalizavam $4,6 \%$ dos estabelecimentos agrícolas (BAHIA, [1972?], t. III).

Esse fato resultava na formação de um grande excedente demográfico no meio rural, que se dirigia inicialmente para as cidades mais próximas, daí para as maiores e, em seguida, para a capital; parte desse excedente demográfico também migrava para fora do estado da Bahia. Sobre a dinâmica da população no Recôncavo Baiano, nesse período, evidencia Santos, M. (1959a, p. 25):

Mais recentemente, a decadência da cultura do fumo tem contribuído para aumentar a população urbana dessa área. Incapaz a zona rural de reter excedentes, um processo migratório tem início e vai se terminar nas maiores cidades da região e em Salvador, sem falar nos que emigram para o Sul do país, ou encontram ocupação nos trabalhos petrolíferos.

Essa assertiva é também corroborada pelos resultados de uma pesquisa dirigida por Beaujeu-Garnier em 1961, sobre a migração de população para a cidade de Salvador, cuja maior parte das famílias entrevistadas $(75,4 \%)$ procedia do próprio Recôncavo. Tal fato levou-a a afirmar que:

[...] plus des quatre cinquièmes des migrants attirés par Salvador viennet d'un rayon de moins de 200 kilomètres autor de la ville, résultats qui s'opposent à l'opinion courante, d'aprés laquelle ce sont surtout les originaires de l'intérieur séc, la région la plus misérable, qui viennent chercher refuge dans la grande ville côtiere (BEAUJEU-GARNIER, 1962, p. 293). ${ }^{11}$

Com efeito, no Recôncavo Baiano, a área petrolífera surge como um centro de forte atração de população, acusando as mais altas taxas de imigração, de $10 \%$ e mais (Tabela 13), e de elevado crescimento urbano, ambos estimulados pelas atividades diretas e indiretas da Petrobras que demandava pessoal, produtos e serviços, em grande escala.

\footnotetext{
${ }^{11}$ [...] mais de quatro quintos dos migrantes atraídos pela cidade de Salvador vêm de uma distância de menos de $200 \mathrm{~km}$ em torno da cidade, resultados que se opõem à opinião corrente, segundo a qual são, sobretudo, os originários do interior seco, a região mais pobre, que vêm buscar refúgio na grande cidade litorânea (BEAUJEUGARNIER, 1962, p. 293, tradução nossa).
} 
Dos dez municípios que acusaram uma taxa de imigração acima de 10\%, apenas dois não faziam parte da RPBA. Os dois municípios que registraram as maiores taxas de imigração foram Candeias, com 37\% e São Francisco do Conde, com 27,3\%, ambos localizados na antiga zona açucareira, e que tiveram como principais fatores de atração de população as atividades de prospecção e extração de óleo e de gás dos primeiros grandes campos de petróleo e gás natural, o desenvolvimento das obras de construção e a posterior ampliação da RLAM e do Temadre. Tais fatores contribuíram para atrair e fixar uma numerosa população nas proximidades imediatas de onde estavam sendo realizadas tais atividades.

As palavras de Souza, G. (1976, p. 46) confirmam esse fato:

Nos anos que vão de 1950 a 1965, correspondentes ao período em que a Petrobras mais recrutou mão de obra, foi significativa a parcela de migrantes absorvida por vários dos municípios onde a empresa atuava, principalmente por Candeias, S. Francisco do Conde e Camaçari.

As elevadas taxas de crescimento urbano verificadas nos municípios petrolíferos, ao longo do período, resultaram do entrelaçamento das seguintes condições:

a) a rede de estradas asfaltadas construída na área de operações da Petrobras favorecia, ao mesmo tempo, as operações de transporte da empresa, a circulação de pessoas e de mercadorias e, consequentemente, os fluxos migratórios de população do campo para as cidades e de uma cidade para outra;

b) as ações da empresa, principalmente nas cidades próximas aos alojamentos dos funcionários, por meio da grande oferta monetária em circulação em forma de salários pagos a seus milhares de funcionários diretos e outros tantos indiretos e pelos gastos diversos da empresa, a título de pagamentos a várias firmas subcontratadas, para execução de seus serviços e aquisição de mercadorias;

c) a maior concentração da propriedade fundiária, inclusive sob domínio da própria Petrobras, como se esclarece: ${ }^{12}$

Levando-se em consideração apenas a estrutura fundiária, observa-se que a Zona Norte é a mais concentrada, ou seja, é aquela onde se localiza o maior número de municípios com elevadas taxas de concentração, destacando-se Camaçari, com grau equivalente a 0,85 [...]. Esta situação tende a perdurar, em face da indivisibilidade das terras da PETROBRAS (antes ocupadas nos trabalhos de perfuração), além da volta recente da pecuária de corte desenvolvida em regime extensivo ( BAHIA, [1972?], t. III, p. 12);

\footnotetext{
12 Segundo informa BAHIA ([1972?], t. III, p. 18), a Petrobras conseguiu adquirir, por mecanismos de desapropriação, cerca de 6.000 ha de terras na RPBA. A superfície total da área que limita o Recôncavo baiano é de 16.071,9 km2, ocupa 2,83\% da área total do estado da Bahia que possui $567.295 \mathrm{~km} 2$. A área total de propriedade da Petrobras na RPBA é de $60 \mathrm{~km} 2$.
} 
Tabela 13 - Recôncavo Baiano: população total e imigrante residentes há até 10 anos no município - 1960

\begin{tabular}{|c|c|c|c|}
\hline \multirow{3}{*}{ Municípios } & \multicolumn{3}{|c|}{ População } \\
\hline & \multirow{2}{*}{ Total } & \multicolumn{2}{|c|}{ Imigrantes } \\
\hline & & Total & $\%$ \\
\hline Candeias & 18.484 & 6.830 & 37,0 \\
\hline São Francisco do Conde & 18.455 & 5.037 & 27,3 \\
\hline Camaçari & 21.849 & 5.121 & 23,4 \\
\hline Mata de São João & 23.393 & 4.604 & 19,7 \\
\hline Catu & 21.721 & 3.754 & 17,3 \\
\hline Pojuca & 8.575 & 1.397 & 16,3 \\
\hline Alagoinhas & 75.422 & 11.869 & 15,7 \\
\hline Salvador & 655.735 & 101.152 & 15,4 \\
\hline Santo Antônio de Jesus & 34.018 & 4.281 & 12,6 \\
\hline Nazaré & 28.258 & 3.323 & 11,8 \\
\hline São Sebastião do Passé & 23.963 & 2.403 & 10,0 \\
\hline Jaguaripe & 11.858 & 1.026 & 8,7 \\
\hline Itaparica & 25.276 & 2.157 & 8,5 \\
\hline Cruz das Almas & 24.196 & 1.870 & 7,7 \\
\hline São Félix & 14.866 & 1.129 & 7,6 \\
\hline Conceição do Almeida & 24.368 & 1.777 & 7,3 \\
\hline Sapeaçu & 13.163 & 858 & 6,5 \\
\hline Conceição da Feira & 11.418 & 531 & 4,7 \\
\hline Maragogipe & 39.742 & 1.735 & 4,4 \\
\hline Cachoeira & 28.869 & 1.179 & 4,1 \\
\hline Santo Amaro & 100.221 & 3.987 & 4,0 \\
\hline Muritiba & 38.046 & 1.314 & 3,5 \\
\hline São Felipe & 24.681 & 816 & 3,3 \\
\hline São Gonçalo dos Campos & 33.434 & 943 & 2,8 \\
\hline Aratuipe & 6.858 & 170 & 2,4 \\
\hline TOTAL & 1.326 .869 & 169.263 & 12,8 \\
\hline
\end{tabular}

FONTE: Organizada por Brito (2004), com base IBGE (1961).

Dessa maneira, o conjunto urbano, ainda que em fase de desenvolvimento, organizado em torno das atividades da Petrobras, passou a constituir uma bacia de força de trabalho, ao tempo em que também se ampliavam os efetivos urbanos e todas as possíveis implicações de um processo de urbanização em 
curso, que servia, muitas vezes, de apoio às necessidades da empresa, como, por exemplo, a instalação de agências bancárias nas cidades mais importantes da RPBA. A presença de agências bancárias nas cidades da RPBA foi deveras importante para a empresa, pois, antes disso, o dinheiro destinado ao pagamento dos salários dos funcionários no campo era transportado de caminhão de valores, sob o risco iminente de assaltos.

A esse respeito registra Azevedo T. (1959a, p. 19), referindo-se ao ano de 1958:

\begin{abstract}
Em uma das cidades aqui referidas, um banco de praça da Capital abriu há 2 meses uma agência que, no dia de sua inauguração recebeu depósitos no total de Cr\$ 6 milhões [U\$ 47.110,55]; hoje tem 105 contas de menos de Cr\$ 200 mil [U\$ 1.570,35], faz um movimento animador e já está construindo seu prédio próprio; por seu intermédio, são pagos os salários de empregados de uma emprêsa empreiteira que executa obras para a PETROBRAS (cerca de Cr\$1.500.000 mensais) [U\$11.777,64]. Noutra cidade abrir-se-á brevemente a agência de outro banco. Ambos os estabelecimentos são os primeiros do gênero nessas cidades.
\end{abstract}

Ainda que não estivesse tão avançada a divisão do trabalho no Recôncavo Baiano, o processo já se tinha iniciado. Dessa maneira, guardadas as devidas proporções e singularidades, a RPBA começava a passar por transformações significativas na organização do espaço geográfico, como se refere Smith (1988, p. 181), "[...] quanto mais avançada esteja a divisão do trabalho, maior tende a ser o número de serviços e atividades acessórias exigidos por um dado processo de produção [...]". Assim, as condições para a expansão das atividades da companhia na RPBA se consolidavam à medida que iam surgindo novas demandas.

Com a expansão das atividades da Petrobras no Recôncavo Baiano, os núcleos urbanos "adormecidos" e os novos que surgiam entraram em um dinâmico processo de crescimento, acompanhado do fenômeno da urbanização que, entretanto, se desenvolvia de maneira mais lenta. Esses núcleos urbanos passaram a desempenhar novos papéis, em decorrência das novas demandas que surgiam a partir de fins dos anos 1950, provocadas, principalmente, pela Petrobras. As impressões de Azevedo, T. (1959a, p. 14) sobre o processo de urbanização na área petrolífera corroboram essa assertiva:

A Petrobras faz o grosso de suas compras na capital do estado; todavia compra algum material de construção, alimentos, medicamentos [...] e outros artigos miúdos nas cidades próximas aos seus serviços, mesmo fora da área de lavra como em Feira de Santana e Alagoinhas. [Em Candeias], ali como noutros "campos" compram-se verduras, ovos, aves, carne, farinha produzidos nos arredores pelo estímulo da demanda de tantos consumidores novos. 
A massa de dinheiro em circulação na RPBA, em forma de salários e gastos diversos da Petrobras, principalmente nas cidades próximas aos alojamentos dos funcionários e aos campos de petróleo e gás, induziu, em pouco tempo, uma grande elevação dos preços nos mercados locais, sobretudo nos itens habitação, alimentação, vestuário e serviços pessoais. Além disso, verificou-se também uma significativa segmentação social e mudança de hábitos na população, indicando a emergência do fenômeno da urbanização destacado por Azevedo, T. (1959a, p. 14):

[...] aumenta o número de bares, sorveterias, farmácias, lojas de miudezas, fazendas, artigos de toilette; surgem casas de artigos elétricos, rádios, móveis, fogões a gaz e a querozene, bicicletas, até geladeiras, tudo denunciando um processo intensivo de urbanização com toda sua fenomenologia sócio-cultural.

O aumento da arrecadação de receitas nos municípios petrolíferos permitia às municipalidades implantar e/ou ampliar a infraestrutura pública como, por exemplo, a pavimentação de ruas, a rede de energia elétrica, a rede de abastecimento de água e saneamento além de outros serviços públicos de uso coletivo. A vida simples das populações dessas cidades se abria à complexidade do novo modo de vida que já começava e se fazer presente.

Por seu turno, a condição de metrópole regional da cidade do Salvador e sua posição geográfica em relação à RPBA consolidou a sua função de "cidade-chave" de segundo nível para as grandes empresas multidivisionais e multilocalizadas, como sugere Hymer (1978). ${ }^{13}$

Na segunda metade da década de 1950, a cidade do Salvador atendia às demandas de contatos mais diretos entre as atividades da empresa no Recôncavo Baiano e sua sede geral na cidade do Rio de Janeiro, os quais eram intermediados pela sede regional em Salvador.

Na cidade do Salvador, desde 1954, localiza-se a sede regional da Petrobras, onde são centralizadas todas as operações desenvolvidas regionalmente e sua abrangência espacial envolve as regiões Norte e Nordeste do Brasil e o estado do Espírito Santo. As funções desempenhadas pelo corpo administrativo da empresa em Salvador inclui desde o provimento do mercado regional com derivados de petróleo até a lavra e industrialização do óleo e do gás natural.

A sede regional da Petrobras em Salvador é responsável pela gerência de pessoal e de compras; por contatos com os fornecedores e compradores de produtos e

\footnotetext{
${ }^{13}$ Chandler (1998), Hymer (1978) e Clark (1985) discutem os mecanismos que levam as grandes empresas multidivisonais e multilocalizadas a localizar seus escritórios da: alta gerência - tomada de decisões - nas grandes cidades (cidades-chave de I nível), junto às sedes de outras grande empresas, bancos, o Governo etc., gerência das atividades desenvolvidas regionalmente e de médio prazo, nas cidades grandes de abrangência regional (cidadeschave de II nível); da gerência das atividades desenvolvidas localmente, junto à fábrica.
} 
serviços e pela coordenação da produção regional. Nessa cidade, reside a maioria dos funcionários ligados à produção e aos setores de direção da empresa na Bahia.

Enfim, todo esse processo sócioeconômico-espacial envolvendo a concentração de força de trabalho em dados locais, a inversão de grande volume de capital de maneira contínua ao longo do tempo, a localização de infraestrutura, indústria e pontos de apoio logístico e outras necessidades, todos mobilizados pela Petrobras em torno de suas atividades, na RPBA, tinha um único sentido, o de prover as demandas requeridas pela própria empresa. A dispersão dos campos de petróleo e de gás natural e a grande escala de produção de matérias-primas desses campos, implicam um amplo alcance espacial das ações diretas da empresa nessa parte do Recôncavo Baiano, suscitando a agregação de novas áreas à RPBA.

Como ficou patente, o período compreendido entre a chegada da Petrobras no Recôncavo Baiano, em 1954, e a realização da "Conferência do Petróleo", em 1959, foi marcado por relações unilaterais praticadas pela estatal sobre seus interlocutores regionais. Essas ações se fundamentavam em uma doutrina militarizada e centralista da antiga gerência da companhia que, amparada na lei do monopólio estatal do petróleo e na ideologia do progresso e da segurança nacional, impunha seus interesses aos demais agentes regionais, os quais, direta e/ou indiretamente eram tocados pelos negócios em torno do petróleo.

Convém salientar mais uma vez, que não havia qualquer tipo de homogeneidade de interesses entre os distintos interlocutores regionais da Petrobras - o Governo baiano, usineiros, banqueiros, fazendeiros, demais empresários, trabalhadores do açúcar e do fumo, políticos e estudantes - a única questão que os unia era tentar quebrar a forma de ação arbitrária do inimigo comum, o que certamente proporcionaria a posteriori o atendimento de parte dos interesses específicos de cada um dos agentes e/ou de alguns.

Apesar de a Petrobras ter realizado vários investimentos na RPBA, contribuindo para as transformações significativas nessa parcela do espaço geográfico, tal fato ocorria em benefício dos interesses microeconômicos da empresa que se contrapunham a ações de natureza macroeconômicas, esperadas por seus interlocutores regionais, os quais tinham suas demandas postergadas e/ou preteridas pela empresa.

Dessa maneira, os agentes regionais, insatisfeitos com a condição de subjugação imposta pela Petrobras, buscavam por vários meios reagir às ações tomadas unilateralmente por um adversário comum e vigoroso. O fato de as relações entre os referidos agentes serem determinadas, até então, predominantemente, por meios coercitivos implicava o não-surgimento de um agente hegemônico nessas relações. Como resultado, a existência de um território estruturado em torno das relações entre a Petrobras e seus interlocutores regionais na RPBA ainda estava por ser construído. 


\section{O processo de expansão organizacional da Petrobras a partir dos anos 1960 e a industrialização do estado da Bahia}

Em 1960, ao realizar uma greve vitoriosa por equiparação salarial com seus companheiros de São Paulo, o Sindicato dos Petroleiros da Bahia já havia descoberto sua força e sua importância política nos meios governamentais - aproveitando-se da permissividade dos governantes populistas - em relação ao monopólio do petróleo. Ao longo dos três anos, nos quais o sindicato dos petroleiros exerceu verdadeira influência na indicação de nomes para a alta direção da Petrobras ele contribuiu diretamente na escolha de quatro presidentes da empresa; todavia, na mesma medida, também contribuía para os destituir, num processo de autofagia (MARINHO JR., 1989; CARVALHO, 1977).

Segundo entrevista concedida por Josaphat Marinho ao jornal A Tarde, a importância política do Sindicato dos Petroleiros da Bahia era tamanha que, se o Presidente Jânio Quadros não tivesse renunciado no início do mandato, possivelmente teria transferido a sede geral da Petrobras, do Rio de Janeiro para Salvador (A BAHIA..., 2001). Essa importância política se sustentava no grande volume de produção de óleo da RPBA e nos compromissos políticos entre os governos populistas e os sindicatos de trabalhadores.

Na sequência das administrações populistas no Brasil, o novo Governo instalado em 1961 tratou de cumprir os compromissos assumidos com os sindicatos e, imediatamente, designou dois baianos: Geonísio Barroso, um técnico de carreira para dirigir a Petrobras, e Josaphat Marinho, um político e professor de direito da Universidade da Bahia para dirigir o CNP. O Presidente da República, no entanto, renunciou com menos de um ano de mandato e, em seu lugar, assumiu o Vice-Presidente da República João Goulart, sob a ameaça de embargo pelas forças políticas conservadoras presentes no Congresso Nacional Brasileiro.

Com o novo Governo e sob nova orientação política, Geonísio Barroso foi substituído pelo professor de direito da Universidade da Bahia, Francisco Mangabeira, que também permaneceu no cargo de presidente da Petrobras por um ano apenas.

O período compreendido entre setembro de 1961 e março de 1964 foi marcado por uma forte instabilidade no ambiente político e institucional brasileiro, com o risco iminente de deposição do Governo constitucional pelas forças de oposição (militares golpistas e políticos conservadores), que conspiravam contra o frágil governo de João Goulart. É nesse contexto que o Governo tenta se equilibrar, buscando atender às demandas do jogo de forças que lhe dava sustentação política; essa situação se refletia diretamente na Petrobras. 
A empresa, por não dispor de recursos técnicos e financeiros suficientes para investir nas custosas atividades de prospecção do óleo no país (em meio a uma conjuntura de inflação elevada), não conseguia descobrir novas jazidas de petróleo fora do Recôncavo Baiano e, com isso, se desmoralizava diante de seus críticos (CARVALHO, 1977). Externamente, as críticas partiam dos opositores do monopólio estatal e internamente, dos funcionários ligados ao Sindipetro, que defendiam o monopólio integral das atividades ligadas ao petróleo no país, a encampação das refinarias particulares e nomeações de funcionários indicados pelo sindicato para cargos de chefia (MARINHO JR., 1989).

Essas críticas aliadas aos compromissos políticos do Governo com os sindicatos contribuíram decisivamente para a efemeridade da ocupação do cargo de presidente da Petrobras. Assim, mais dois presidentes - Albino Silva (06/1963 a 01/1964) e Osvino Alves (01/1964 a 04/1964), ambos oficiais militares de alta patente - ocuparam, sem sucesso, o posto de presidente da companhia, pois não conseguiram atender integralmente às demandas do sindicato.

A instabilidade da alta cúpula da Petrobras refletia a precariedade política do Governo de João Goulart até o golpe militar de 31 de março de 1964.

Durante o aludido período, a empresa acumulou prejuízos com o baixo desempenho apresentado ano a ano e, com isso, ocorreu o desgaste político diante da opinião pública, provocado pelas disputas de posições internas entre as correntes sindicais e os quadros tecnocráticos. Amparado pela opinião majoritária do Governo, ou seja, pela defesa do monopólio do petróleo, o escopo autonomista dos quadros tecnocráticos da companhia (privilegiar os interesses microeconômicos) resistia aos interesses exclusivamente corporativistas dos sindicatos e também ao assédio dos grupos regionais de pressão.

Nesse ínterim, ao lado dos demais investimentos da Petrobras (programados e em desenvolvimento em algumas partes do país) para o Recôncavo Baiano, em cumprimento de alguns pontos do acordo proclamado na Carta do Petróleo ficaram decididas, a partir de 1961, a implantação e a operação pela companhia dos seguintes empreendimentos: uma fábrica de asfalto junto ao Temadre; o Conjunto Petroquímico da Bahia (Copeb), em Camaçari, constituído de uma fábrica de amônia e outra de uréia ${ }^{14}$; uma fábrica de gasolina natural junto à refinaria de Mataripe, com capacidade para processar 400 a $450 \mathrm{~m}^{3} / \mathrm{dia}$ de líquido de gás natural; novas ampliações na RLAM e demais investimentos (BAHIA: UM... 1971; PLANTA DE... 1962).

As fábricas de amônia e de uréia foram dimensionadas para produzir 200 e 250 toneladas por dia, dos respectivos produtos, para produção de fertilizantes nitrogenados à base de gás natural proveniente dos campos do Recôncavo Baiano.

\footnotetext{
${ }^{14}$ Atualmente o antigo Copeb constitui a Fábrica de Fertilizantes Nitrogenados (Fafen) da Petrobras.
} 
Para extração de gasolina natural estavam sendo construídas desde 1961, duas unidades de processamento de gás localizadas, uma no município de Catu e outra em Candeias. Nessas unidades de processamento são retirados do gás natural: gasolina, propano, butano e hexano, que são enviados, por dutos, para a fábrica de gasolina natural na refinaria. Empobrecido, o gás retorna aos campos para ser reinjetado nos poços, com o fim de manter a pressão interna para favorecer a recuperação do óleo.

Ainda em cumprimento ao acordo da Carta do Petróleo, a Petrobras, buscou atender à orientação do CNP (dirigido à época por Josaphat Marinho), procedendo a majoração do percentual da taxa de royalty, de $5 \%$ para $8 \%$ destinado ao estado da Bahia, e de $1 \%$ para $2 \%$ em favor dos municípios petrolíferos. A empresa também ampliou esses direitos para a exploração submarina - medida extensiva a outras partes do país - ao mesmo tempo passou a pagar os respectivos royalties atrasados referentes aos campos submarinos.

A execução de tudo isso se daria, porém, sem a participação acionária de capitais privados, o que atendia só parcialmente às demandas dos grupos empresariais regionais (banqueiros, usineiros e grandes comerciantes), que pleiteavam participar dos negócios do petróleo e do gás natural.

Mesmo com esse novo ânimo esboçado pela nova orientação dos investimentos da Petrobras no Recôncavo Baiano, os grupos regionais de pressão (banqueiros e demais empresários), interessados na definição de uma nova política de ação econômica da companhia no Recôncavo Baiano, não lograram os benefícios almejados, pois esses grupos ainda permaneceriam por mais algum tempo alijados de uma atividade econômica mais robusta e de longa duração proporcionada pela Petrobras. Contudo, esses agentes eram contemplados com a contratação temporária de vários tipos de serviços, desde obras civis e de montagens industriais até transporte de valores.

Nesse lapso de tempo, a economia baiana seguia sua trajetória de tendência declinante. Os capitais regionais reproduziam-se de maneira precária e limitada, dependentes de contratação de serviços do Governo estadual (este sem boas perspectivas de arrecadação financeira), de serviços extras da Petrobras e da lavoura cacaueira (secundada pelo fumo, pela mamona, pelo sisal e por outros produtos primários) que, embora lucrativa como as demais, também dependia das flutuações de safras e dos preços nos mercados estrangeiros.

Do lado da indústria, não se podia alimentar grandes aspirações, pois, em grande parte, era constituída de pequenas firmas, cada qual com quatro funcionários em média. Em 1960, o conjunto de firmas industriais gerou em média cerca de U\$ 2.300 por estabelecimento; mas em meio a uma miríade de firmas pequenas e de pouca expressão econômica se destacava quase uma centena de firmas, entre as quais, a refinaria da Petrobras, usinas de açúcar, fábricas têxteis, 
fábricas de fumo, moinhos de trigo etc., que eram responsáveis pela geração de cerca de $70 \%$ do Valor da Transformação Industrial (VTI), ocupando menos de $2 \%$ dos estabelecimentos industriais (Tabela 14).

Tabela 14 - Firmas industriais: constituição jurídica e valor da transformação industrial no estado da Bahia - 1960

\begin{tabular}{|c|c|c|c|c|}
\hline $\begin{array}{l}\text { Constituição } \\
\text { jurídica }\end{array}$ & $\begin{array}{l}\text { Estabele- } \\
\text { cimentos }\end{array}$ & $\begin{array}{c}\% \text { do total de } \\
\text { estabelecimentos }\end{array}$ & $\begin{array}{c}\text { Valor da } \\
\text { trasformação } \\
\text { industrial (U\$) }\end{array}$ & $\begin{array}{l}\% \text { do total do } \\
\text { Valor da transfor- } \\
\text { mação industrial }\end{array}$ \\
\hline Firmas individuais & 5.224 & 87,8 & 11.954 .179 & 13,5 \\
\hline $\begin{array}{l}\text { Sociedades de respon- } \\
\text { sabilidade limitada }\end{array}$ & 340 & 5,7 & 11.172 .805 & 12,6 \\
\hline Sociedades de pessoas & 245 & 4,2 & 3.221 .850 & 3,6 \\
\hline Sociedades anônimas & 97 & 1,6 & 61.722 .550 & 69,6 \\
\hline Entidades públicas & 30 & 0,5 & 507.876 & 0,6 \\
\hline Outras & 14 & 0,2 & 68.715 & 0,1 \\
\hline TOTAL & 5.950 & 100 & 88.647 .975 & 100 \\
\hline
\end{tabular}

FONTE: Organizada por Brito (2004), com base IBGE (1966).

Em 1960, o Recôncavo Baiano concentrava 24\% de todos os estabelecimentos industrias da Bahia e $47,2 \%$ do total do VTI; no município de Salvador, estavam localizados $47,7 \%$ dos estabelecimentos industriais existentes no Recôncavo Baiano, nos quais foram gerados $54,7 \%$ do VTI.

Em situação financeira limitada, a maioria das firmas, utilizando tecnologia arcaica, não estava em condições de produzir mercadorias em quantidade, qualidade e preços suficientes para competir com as mercadorias vindas de outras partes do país, principalmente do eixo São Paulo/Rio de Janeiro.

No final dos anos 1950, o centro econômico nacional - São Paulo/Rio de Janeiro - já dispunha de um parque industrial complexo, constituído de indústrias - automotivas, de máquinas, químicas e petroquímicas, siderúrgicas, de plásticos, de material elétrico etc. -, com elevado grau de sinergia a jusante e a montante, e que se ampliava rapidamente. Apesar da grande distância física entre essa região e a Bahia, já relativizada pelo uso corrente do transporte de cargas por caminhões, as mercadorias de melhor qualidade e preço, procedentes desse eixo urbano-industrial em expansão, disputavam, com grande vantagem, o mercado de consumo baiano e deslocavam as mercadorias produzidas localmente para as áreas de mercado constituídas de consumidores de baixa capacidade de compra, tanto na capital, como no interior (CASTRO, 1975).

A penetração de mercadorias em certas áreas de mercado na Bahia, em quantidade cada vez maior, provenientes do eixo São Paulo/Rio de Janeiro passou a ser mais efetiva a partir da conclusão do asfaltamento da rodovia BR 116 
- Rio/Bahia -, em 1963. Esse fato, devido à flexibilidade de entrega de mercadorias porta a porta, associado ao deslocamento de pequenos volumes, compensava o preço do frete de longa distância (MANZAGOL, 1985); isso favorecia sobremaneira um volume crescente de intercâmbio de mercadorias entre a Bahia e o eixo industrial São Paulo/Rio de Janeiro.

Se não bastassem a conjuntura de altas taxas de inflação, os salários muito baixos e a ação essencialmente especulativa dos grandes capitalistas regionais, uma grande área do estado da Bahia (mais de 60\%) localiza-se nos limites de clima semi-árido - polígono das secas - sujeito a fortes e constantes secas como as que ocorreram em 1952 e em 1958; esta última teve seus efeitos negativos prolongados até 1962 .

Ao lado do fator natural negativo, porém tecnicamente contornável, colocavam-se, implacavelmente, as ações dilapidadoras dos coronéis do sertão (LEAL, 1976) e das demais áreas rurais e pequenas cidades da Bahia articulados, por meio do voto e da clientela, à burguesia mercantil/financeira e letrada da capital (SAMPAIO, N., 1960), que juntos agravavam (e continuam agravando) consideravelmente, as possibilidades de progresso econômico e social da Bahia.

Para se ter uma medida do grau de atraso das oligarquias baianas, nas eleições municipais de 1976, o partido governista, a Aliança Renovadora Nacional (Arena), apresentou elevado desempenho eleitoral nos municípios com até 10.000 habitantes: $87,4 \%$ e $78,4 \%$ dos votos apurados para prefeitos e vereadores, respectivamente; e nos municípios de baixo grau de urbanização: $88,3 \%$ e $74,8 \%$ dos votos apurados para prefeitos e vereadores, na mesma ordem (BAHIA..., 1979). Apesar de não ser exclusivo da Bahia, isso indica uma forte correlação com vínculos coronelistas, já identificados por Sampaio, N. (1960) nas eleições municipais baianas de 1959.

Nessas condições, as bases econômicas para a reprodução futura dos capitais regionais no estado da Bahia já estavam comprometidas a priori, enredadas nos laços da aliança entre as oligarquias mercantil-financeiras e os coronéis do Sertão, que reproduziam o "enigma baiano", representado pelo longo processo de letargia econômica.

Todavia, o estado da Bahia não estava sozinho nesse ambiente de estagnação econômica, causadora de conseqüências sociais e políticas gravíssimas. Com ele também estavam todos os estados da "recém-descoberta região problema" - o Nordeste brasileiro - em meio a um processo de quase convulsão social devido ao seu nível de pobreza extrema. A condição de pobreza em processo de agudização empurrava as massas de trabalhadores rurais e não proprietários (pequenos produtores) ao movimento de organização e preparação para uma forma de ação revolucionária iminente (OLIVEIRA, F., 1987b; COHN, A., 1978).

No sentido de tentar superar as dificuldades sociais e econômicas da região e integrá-la ao mercado nacional, o Governo federal decidiu criar, em 1959, mais 
um órgão de ação exclusiva no Nordeste, a Superintendência do Desenvolvimento do Nordeste (Sudene), para agir de maneira planejada e com recursos técnicos e econômicos suficientes ao fomento econômico da região.

Antes da criação da Sudene, já agiam de maneira setorial no Nordeste os seguintes órgãos federais: Departamento Nacional de Obras Contra as Secas (Dnocs), em 1945, que substituiu a Inspetoria de Obras Contra as Secas (Ifocs), de 1909; Comissão do Vale do São Francisco (Codevasf), de 1948; Companhia Hidrelétrica do São Francisco (Chesf), em 1948; Banco do Nordeste do Brasil (BNB), em 1952, este, por sua condição de banco de fomento econômico, tinha uma ação mais ampla e planejada; todos eles, porém, passaram a ser controlados pelas oligarquias regionais (OLIVEIRA, F., 1987b).

Para além de um inócuo programa de combate aos efeitos das secas, inicialmente a ação da Sudene previa desenvolver um processo de industrialização com a implantação de indústrias novas, principalmente siderúrgicas, e a reestruturação das tradicionais, além de dar apoio à agricultura em seus setores mais dinâmicos, privilegiando a elevação da produtividade e a diversificação dos produtos. Excluía-se dos propósitos da Sudene, a reforma agrária.

O primeiro Plano Diretor da autarquia, aprovado pelo Congresso Nacional em dezembro de 1961, trazia embutido um mecanismo financeiro importante para dar suporte à promoção dos investimentos econômicos na região. Esse mecanismo consistia na dedução de até $50 \%$ do imposto de renda devido das pessoas jurídicas de capital totalmente nacional para inversões produtivas no Nordeste.

A referida proposta foi uma alternativa à extinção pelo Governo Federal, no mesmo ano, do incentivo à importação estrangeira de máquinas, equipamentos e insumos industriais. Como explica Castro (1975), essa proposta teve inspiração no programa de recuperação econômica aplicado em 1959, no Sul da Itália. O programa de apoio ao Nordeste via incentivos fiscais da Sudene representava para os grupos regionais implicados a recompensa de uma dívida antiga do Governo federal, desde o primeiro governo de Vargas, para com os estados dessa região.

Durante o ano de 1962, os capitais que aportavam no Nordeste ainda não apresentavam o volume desejado e, para isso, uma modificação na lei de incentivos fiscais da Sudene alterou substancialmente a importância das inversões financeiras na região, com a introdução do "mecanismo 34/18". Por meio desse artifício, todas as pessoas jurídicas do país e estrangeiras com negócios no Brasil poderiam deduzir até $50 \%$ do imposto de renda devido para aplicar no Nordeste e ainda dispor de outros incentivos governamentais. Dessa vez, os efeitos nos cofres da Sudene foram surpreendentes, os investimentos passaram a chegar em maior volume e mais rapidamente, já a partir de 1963.

Faz-se mister destacar que um dos fatores preponderantes para a forte migração de capitais da região brasileira mais próspera, o Sudeste, para o Nordeste foi, 
sem dúvida, o "excesso planejado" de infraestrutura produtiva localizada no eixo São Paulo/Rio de Janeiro (COUTINHO; REICHSTUL, 1983). Essa capacidade tecnoprodutiva ociosa, caracterizada pela indivisibilidade técnica das plantas industriais, que foi seletivamente instalada nessa parte do país ao longo da implementação do "Plano de Metas", do governo Juscelino Kubitschek, efetivou-se segundo uma perspectiva de antecipação de mercado para as firmas estrangeiras, produtoras de bens de consumo duráveis, que fizeram a opção pelo Brasil naquele período.

Os volumosos investimentos foram realizados por agentes privados, sobretudo estrangeiros, e estatal, via endividamento externo. Como resultado disso, e diante da capacidade de consumo do mercado brasileiro, limitada em volume e qualidade, surgiu uma grande crise de realização econômica iniciada a partir de 1962 e que se estende até 1967 (TAVARES, 1986). É em meio a essa crise econômica que se encontra a raiz da explicação de uma menor resistência dos capitais sediados na região econômica mais próspera para se deslocarem para a região Nordeste.

De outro modo, as vantagens econômicas concedidas pelo Governo federal com a adoção dos artigos 34/18, contidos no segundo Plano Diretor da Sudene, de 1963, produziram, ao final, efeitos animadores no processo de industrialização do Nordeste e dessa maneira, criaram a possibilidade de expansão mais rápida do mercado de consumo nacional para os bens de consumo duráveis.

As indústrias que passaram a se instalar na região Nordeste, a partir de então, eram, em grande parte, novas, intensivas em capital e produtoras de bens intermediários; essa base industrial era complementar, portanto, às indústrias localizadas na região Sudeste. Dessa maneira, o processo de "desconcentração concentrada" cumpriria sua dupla função: de um lado, conter a efervescência das massas agrárias na região mais pobre, ao tempo em que forjava a emergência de uma classe social com relativa capacidade de consumo, via melhor remuneração nas indústrias; por outro lado, ampliar o processo de produção/acumulação e centralização do capital no Brasil, com a instalação de filiais industriais.

É com essa ferramenta indispensável às políticas de atração dos desejados investimentos econômicos, por meio de mecanismo de subsídios líquidos ao capital privado, que a burocracia do estado da Bahia estava se preparando para tentar operar o processo de redenção econômica baiana. Esse processo demoraria mais meia década para se efetivar e demandaria mais investimentos, dessa vez, estaduais, para ganhar materialidade efetiva na construção do Centro Industrial de Aratu (CIA) e, posteriormente, também do Complexo Petroquímico de Camaçari (Copec).

Ao lado disso, ocorre a derrubada do governo João Goulart em 31 março de 1964. O novo Governo é logo ocupado pela junta militar, com o Marechal Castelo Branco à frente. De imediato, o novo Governo interveio na Petrobras, nomean- 
do o também Marechal Ademar de Queiroz para a presidência da empresa. Sob o regime de força, a empresa dispensou imediatamente 467 funcionários por motivos ideológicos (MARINHO JR., 1989), isso seria a senha para o restabelecimento da autoridade da diretoria executiva da companhia.

A grave crise econômica instalada no país entre 1962 e 1967 impunha à Petrobras a tarefa mais que necessária de descobrir novas fontes de abastecimento nacional de óleo, para evitar a saída maciça dos desejados e tão necessários dólares que se desviavam para importação do petróleo.

Com esse propósito e visando uma possibilidade de atingir sua própria autonomia financeira, a partir de 1964, a diretoria executiva da empresa decidiu por em prática um vasto programa de investimentos em refinação: ampliação da Reduc, aumentando em 45 mil bpd sobre os 110 mil bpd existentes desde sua inauguração, em 1961; ampliação de mais seis mil bpd na capacidade de refino da RLAM, que era de 42,5 mil bpd em 1960; aceleração das obras de construção das refinarias Gabriel Passos, em Betim-MG, e Alberto Pasqualini, em Canoas-RS, ambas com capacidade de processar 45 mil bpd; em 1965, foram concluídas as Fábricas de Asfalto, uma em Fortaleza-CE e outra junto ao Temadre, na Bahia; além da conclusão de numerosos investimentos em dutovias em várias partes do país, aquisição de navios petroleiros, construção e ampliação de terminais de carga e a realização de maciços investimentos na pesquisa e exploração de óleo e de gás (MARINHO JR., 1989; NÃO..., 1966).

A ação empresarial mais agressiva da Petrobras pós-1964 resultou também na descoberta de novos e maiores campos de petróleo no Recôncavo Baiano (Miranga e Araçás dentre outros), no estado de Sergipe (Carmópolis), e em incursões na plataforma submarina dos estados de Alagoas e Sergipe.

Dessa maneira, surpreendentemente, a meta de atingir a produção de 150 mil barris de petróleo por dia até 1970 já tinha sido alcançada em 1967.

Essa nova fase de ação da Petrobras veio em resposta à necessidade de o Governo federal não deixar declinar ainda mais o nível da atividade econômica no país, que atravessava um período bastante difícil. O Setor Produtivo Estatal (SPE) foi chamado a participar de maneira decisiva na economia brasileira.

O Ministro do Planejamento Roberto Campos, pretendendo que o próprio mercado se auto-regulasse, o que gerou o fechamento de um grande número de firmas menos eficientes, em meio a um ambiente de forte grau de oligopolização e desnacionalização da economia, buscou equacionar as elevadas taxas de inflação aplicando um rígido programa de controle fiscal, tributário e contendor de aumentos dos salários; ainda nessa perspectiva apoiou, seletivamente, o autofinanciamento de algumas empresas estatais, como a Petrobras, para desenvolver estritamente a produção e refino de óleo determinado pela Lei n 2.004 (COUTINHO; REICHSTUL, 1983). 
Portanto, foi o próprio Governo, por intermédio do ultraliberal Ministro do Planejamento, Roberto Campos, que injetou dinheiro na companhia proporcionando um grande passo para a autonomia financeira, como ressalta Marinho Jr. (1989, p. 345-346):

\begin{abstract}
Paradoxalmente, foi o arquiinimigo do monopólio estatal, Roberto de Oliveira Campos, ministro do planejamento do governo Castelo Branco (1964-67), que comandou a transferência de uma soma impressionante de recursos financeiros para a PETROBRAS, o que permitiu ampliar as atividades nos setores de pesquisa e lavra e empreender "num amplo programa de investimentos". Com a eliminação do subsídio ao consumo de derivados do petróleo, a reformulação da Lei do Imposto único sobre combustíveis líquidos (Decretolei $n^{\circ}$ 61/66), a vinculação das importações de petróleo às exportações de manufaturados brasileiros, a elevação da taxa de câmbio para petróleo e outras decisões do Ministério do Planejamento, aumentou substancialmente o nível de recursos da empresa.
\end{abstract}

Nessa nova dinâmica da organização, ainda em 1964, a empresa executou seu plano de reestruturação organizacional para tornar-se mais ágil diante da retomada de sua nova expansão. Em 1965, a Petrobras iniciou o ano com uma nova estrutura organizacional - departamental.

A departamentalização é uma estrutura verticalmente integrada e complexa, que permite maior autonomia e agilidade nas tarefas da companhia, ao contrário da estrutura organizacional anterior, centralizada na diretoria executiva, que já não correspondia às novas necessidades da empresa. A nova estrutura organizacional foi estabelecida com a criação dos seguintes Departamentos: Exploração e Produção, Industrial, Comercial e de Transporte, além de seis órgãos de Serviços, que por sua vez englobavam várias Consultorias e Assessorias (DIRETORIA..., 1966).

Nesse período, no Recôncavo Baiano, as atividades da Petrobras continuavam bastante firmes, na produção de óleo e de gás natural, com as descobertas de novos campos; no refino, com as novas ampliações da RLAM e a construção da fábrica de asfalto junto ao Temadre; no encaminhamento das obras das fábricas de uréia e amônia; em investimentos em construção de estradas de serviços; em demais obras de construção e de montagem industrial; e em outras demandas por serviços industriais, principalmente, nos que atraíam para sua órbita a instalação de novas indústrias - especialmente as metalúrgicas e mecânicas - beneficiando-se dos incentivos fiscais da Sudene.

Os efeitos desses investimentos da Petrobras no Recôncavo Baiano associados ao apoio financeiro da Sudene contribuíram para a instalação e modernização de indústrias metalúrgicas e mecânicas, em boa parte servindo de suporte às demandas da Petrobras. Segundo os dados do censo industrial, no estado da Bahia, em 1950, existiam apenas 16 estabelecimentos da indústria metalúrgica e dois 
da indústria mecânica; em 1960, passam a existir 55 estabelecimentos do primeiro gênero e seis do segundo; em 1970, aumentam para 206 e 144 e, em 1980, somam 332 e 98 o número de estabelecimentos industriais, respectivamente.

Essas atividades, contudo, ainda não representavam nenhuma certeza na consolidação de um desenvolvimento industrial futuro da Bahia, tendo em vista o fato de os interlocutores regionais da Petrobras já anteverem a escassez do petróleo do Recôncavo Baiano em pouco tempo, segundo o ritmo crescente de sua extração. Dessa maneira, os investimentos industriais mais importantes da companhia, desejados pelos interlocutores regionais, poderiam não se concretizar finalmente, diante da tendência da racionalidade microeconômica esboçada pela tecnoburocracia da empresa de continuar realizando seus investimentos mais importantes no Centro-Sul, pois a companhia estava envolvida no projeto de expansão do refino, o que demandava grandes aplicações de recursos na construção de duas novas refinarias: uma em Betim-MG e outra em Canoas-RS, além da ampliação das demais.

O esgotamento do petróleo nos campos do Recôncavo Baiano e suas consequências negativas para os investimentos da Petrobras na Bahia, constituía o maior temor dos articuladores regionais para a instalação da indústria petroquímica nessa unidade da federação. No período pós-1964, os articuladores da instalação da indústria petroquímica na Bahia tinham como interlocutores os altos escalões do Governo federal e a tecnoburocracia estatal do petróleo, como ficou patente nas palavras do experiente Rômulo Almeida algum tempo depois, em 1972, por ocasião da realização do Simpósio Franco-Brasileiro sobre a Indústria Petroquímica, em Salvador: ${ }^{15}$

\begin{abstract}
O último aspecto a aflorar é o da reserva dos recursos de óleo e gás para a indústria petroquímica. Por enquanto, dispomos de reservas muito pequenas. Seria sábio esgotá-las na política tradicional de economizar divisas? Por várias razões diríamos que não. Primeira, os recursos são escassos e assim, por motivo de segurança, devemos reduzir sua exploração; segunda, sua utilização em petroquímica é muito mais vantajosa; terceira, o óleo baiano tem condições especiais para a petroquímica; [...].

Portanto, é bem avisada a política da PETROBRAS de ir reduzindo a produção nacional, do mesmo passo que elevando a taxa de recuperação das jazidas. Mas nos atreveríamos a submeter que, nas condições presentes do Brasil e do mundo, essa política se deve explicitar no sentido de reserva de recursos para a petroquímica (ALMEIDA, 1973, p. 29).
\end{abstract}

${ }^{15}$ O economista baiano Rômulo Almeida era um dos mais conceituados membros da equipe econômica do segundo governo Vargas. Homem de visão mais larga e desenvolvimentista foi sob sua liderança que se originou o projeto de criação da Petrobras em 1951. 
O sinal positivo para que a indústria petroquímica pudesse se instalar na Bahia foi finalmente dado em 1968, com a autorização do CNP, para a Petrobras operar também na petroquímica, por meio de uma subsidiária - a Petrobras Química S/A (Petroquisa) -, com a publicação do Decreto $n^{\circ}$ 61.981, de 28 de dezembro de 1967 (BRASIL, 1967). Até esse momento, nada assegurava, entretanto, a efetivação de grandes investimentos petroquímicos na Bahia, além da fábrica de fertilizantes da Petrobras Fertilizantes (Petrofértil) cuja operação se iniciava em 1968, no Copeb, organizado pela Petrobras, no município de Camaçari. Todavia, os capitais regionais, ávidos por uma nova forma de reprodução mais segura e previsível, eram deixados de fora da nova indústria que timidamente surgia na Bahia.

O núcleo petroquímico do Copeb teve um custo estimado de aproximadamente U\$ 26 milhões, financiado pelo Banco Nacional de Desenvolvimento Econômico (BNDE) e pela Petrobras. O Copeb estava sendo equipado com a seguinte infraestrutura: uma central térmica com três caldeiras de $10 \mathrm{t} / \mathrm{h}$ cada uma; um gasoduto com $20 \mathrm{~km}$ de extensão e capacidade de escoamento de 500 mil metros cúbicos/dia; uma central de ar comprimido com seis compressores; uma estação de tratamento de água com capacidade para abastecer uma cidade de 100 mil habitantes; uma torre de resfriamento de água e um sistema de captação e adução de água com sete poços de 200 metros de profundidade entre outros equipamentos (BAHIA..., 1971).

Próximo ao Copeb, entre 1968 e 1970, aproveitando os incentivos fiscais da Sudene e o apoio financeiro do BNDE e dos demais órgãos de fomento econômico, bem como a oferta de matérias-primas fornecidas pela Petrobras - gases de síntese da RLAM e o gás natural -, além da fábrica de fertilizantes com capacidade de produção inicial de 72 mil t/ano de amônia e 90 mil t/ano de uréia, também já se encontravam em funcionamento uma fábrica de cerveja da Companhia Industrial de Bebidas da Bahia (Cibeb) e outra da Companhia Industrial Química do Nordeste (Ciquine) e a fábrica Ciquine Química; mais três empreendimentos estavam em construção e outros três estavam à espera de autorização pela Comissão de Desenvolvimento Industrial (CDI); funcionavam ainda duas outras grandes companhias, uma química, a Titânio do Brasil (Tibras) e outra de minerais nãometálicos, a Céramus. Todos esses empreendimentos estavam localizados no município de Camaçari (VIANA FILHO, 1984; O QUE..., 1974).

Como uma medida de centralização do Governo federal, todos os projetos industriais, para serem implantados, teriam de passar, primeiro, pelo julgamento do CDI, criado pelo Decreto n 53.898, de 29 de abril de 1964 (BRASIL, 1964a), pois esse órgão é que aprovava a autorização das concessões dos benefícios governamentais a serem utilizados pelas empresas. Antes de serem analisados pelo CDI, os projetos eram submetidos aos respectivos Grupos Executivos, criados pelo Decreto 
n 53.975, de 19 de junho de 1964 (BRASIL, 1964b), para apresentarem as devidas orientações no sentido de uma melhor performance industrial de acordo com os interesses do Governo. No caso dos projetos químicos, ambos eram avaliados pelo Grupo Executivo das Indústrias Químicas (Geiquim), posteriormente transformado no Grupo Setorial III (GSIII). O Geiquim era subordinado ao CDI e este, por sua vez, era subordinado ao Ministério da Indústria e Comércio (MIC).

\section{A fundação do Centro Industrial de Aratu}

Enquanto a Petrobras e o Governo federal não tinham uma decisão definitiva sobre a instalação de um complexo industrial químico na Bahia, tão desejado pelas forças políticas e econômicas regionais, o Governo baiano agia também em outra frente. Sem descuidar da petroquímica, o Governo estadual investia decididamente em políticas de reestruturação e renovação das indústrias tradicionais (fumo, couro, têxtil, alimentos, bebidas etc.) e, principalmente, na atração de outros tipos de indústrias de transformação, notadamente a metalurgia, em especial a de não-ferrosos e a metalmecânica que abririam novas perspectivas econômicos para o Estado.

Além dos incentivos fiscais da Sudene e de outras subvenções concedidas pelo Governo federal, o Governo estadual também disponibilizou uma importante contribuição fiscal para atrair indústrias para o estado por meio da redução de $60 \%$ do Imposto sobre Circulação de Mercadorias (ICM), por cinco anos, recolhidos ao Banco de Desenvolvimento do Estado da Bahia (Desembanco), para posterior reinversão na própria indústria, a fim de produzir melhorias no empreendimento. A partir de 2001 a instituição foi reestruturada e passou a chamar-se Desenbahia.

O Desembanco surgiu como decorrência da reforma administrativa do Governo estadual implantada na administração de Lomanto Junior (1963-1967). Essa reforma já vinha sendo preparada desde 1955 na administração de Régis Pacheco, quando foram dados os primeiros passos em direção ao planejamento, com a criação da Comissão de Planejamento Econômico (CPE) e demais órgãos de fomento econômico que foram sendo constituídos nas administrações seguintes. A reforma administrativa do governo Lomanto Junior teve como pressuposto um esforço de aperfeiçoamento do aparelho administrativo estadual, com vistas à aplicação mais racional dos recursos públicos orientados para o desenvolvimento regional.

O Governo estadual também procedeu a um grande investimento da ordem de U\$ 23,6 milhões entre 1967 e 1970, na preparação da infraestrutura industrial do CIA, com a construção do porto de Aratu; de ramais ferroviários (10 km) e 
rodoviários ( $8 \mathrm{~km}$ ); além disso, construiu mais de $80 \mathrm{~km}$ de rodovias internas; implantou uma rede de energia elétrica, de telecomunicações e de sistema de adução e de distribuição de água industrial, além de outros beneficiamentos diretos como terraplanagem e loteamento de terrenos, os quais foram vendidos às empresas por preços simbólicos. O CIA ocupa uma área total de 5.300 ha e está localizado nos municípios de Simões Filho e Candeias, contíguos ao município de Salvador (VIANA FILHO, 1984).

Para dar uma dimensão do considerável tamanho do esforço financeiro e político do Governo estadual, no sentido de produzir as externalidades custosas para atrair as indústrias para o $\mathrm{CIA}$, sublinha o ex-governador:

\begin{abstract}
Até 1967 a Bahia tinha pouco mais de 210.000 cruzeiros [cerca de U\$ 79 miIhões] de investimentos aprovados pela SUDENE. No período de 1967/1970 foram aprovados 2.000 .000 [quase $U \$ 440$ milhões] [...]. O que significa que dos investimentos aprovados pela SUDENE, nos seus dez primeiros anos de existência $90 \%$ o foram entre 1967 a 1970. E se antes de 67 a Bahia tinha apenas 36\% do concedido pela SUDENE, situando-se depois de Pernambuco, em 1970 veio a ocupar o primeiro lugar com $45 \%$ dos projetos aprovados.

[...] Em síntese, tínhamos, em 1970, 25 empresas em plena produção; 37 em fase de implantação; e 125 com carta de opção (VIANA FILHO, 1984, p. 30).
\end{abstract}

No estudo realizado por Sampaio, F. (1974), é demonstrado o rompimento da vinculação anteriormente existente entre a indústria baiana e o setor agropecuário, a partir do processo de industrialização apoiado pela Sudene. As indústrias localizadas no CIA, em suas adjacências e na área industrial localizada no município de Salvador, têm como matérias-primas e insumos básicos os minerais não-metálicos, em especial o petróleo.

$\mathrm{Na}$ análise da procedência das matérias-primas e insumos utilizados pelas indústrias localizadas no referido cenro industrial, a maior parte era adquirida no próprio estado da Bahia, seguido da região Sudeste, como mostra a Tabela 15. Mas, dependendo do tipo de indústria, dos produtos processados e de a indústria ter passado por ampliação ou modernização, essa parcela pode aumentar ou diminuir.

O mesmo autor constata ainda que:

Efetivamente, em média, tão somente $28,9 \%$ da produção das empresas novas destinam-se ao mercado regional (Norte e Nordeste), neles incluído o baiano, enquanto a maior parcela das vendas se orienta para outros mercados, notadamente o do Sudeste do país. No que diz respeito às indústrias em ampliação e modernização, a dependência de mercados extra-regionais é menor (SAMPAIO, F., 1974, p. 85). 
Tabela 15 - Participação percentual do valor das matérias-primas e materiais secundários das empresas novas e em ampliação/modernização do sistema Sudene, de acordo com a procedência - 1963/1973

\begin{tabular}{l|c|c|c|c|c|c}
\hline \multirow{2}{*}{$\begin{array}{c}\text { Grupos de } \\
\text { indústrias }\end{array}$} & Bahia & $\begin{array}{c}\text { Nordeste } \\
\text { menos Bahia }\end{array}$ & $\begin{array}{c}\text { Sudeste e } \\
\text { outros estados }\end{array}$ & $\begin{array}{c}\text { Não- } \\
\text { especificado }\end{array}$ & Exterior & TOTAL \\
\cline { 2 - 5 } Novas & 48,0 & 9,0 & 26,9 & 1,6 & 14,5 & 100,0 \\
Tradicionais & 58,6 & 16,2 & 15,6 & 0,0 & 9,6 & 100,0 \\
Dinâmica & 46,1 & 7,6 & 29,0 & 1,9 & 15,4 & 100,0 \\
Ampliação/ & & 15,3 & 12,5 & 0,0 & 3,6 & 100,0 \\
Modernização & 68,6 & 0,5 & 4,5 & 0,0 & 14,0 & 100,0 \\
Tradicionais & 81,0 & 0,5 & 0,0 & 0,9 & 100,0 \\
\hline Dinâmicas & 65,4 & 19,2 & 14,5 & 0,0 & \\
\hline
\end{tabular}

FONTE: Sampaio, F. (1974, p. 84).

Esse fato revela a natureza funcional e integrada dos capitais centralizados no Centro-Sul que se deslocaram para a região Nordeste em busca de maior valorização. Indica ainda o tipo de indústria que se instalou na Bahia e na região Nordeste que é basicamente produtora de bens intermediários, complementares às indústrias de bens finais, localizadas no Centro-Sul. Esse tipo de industrialização, por um longo tempo, até atingir um determinado grau de amadurecimento relativo da economia regional, caracterizou-se como quase enclave (Tabela 16).

Tabela 16 - Participação percentual do valor da produção das empresas novas e em ampliação/modernização do sistema Sudene, segundo o mercado consumidor - 1963/1973

\begin{tabular}{l|c|c|c|c|c}
\hline \multirow{2}{*}{ Grupos de Indústrias } & \multicolumn{4}{|c|}{ Mercados } & \multirow{2}{*}{ Total } \\
\cline { 2 - 5 } & $\begin{array}{c}\text { Norte / } \\
\text { Nordeste }\end{array}$ & Nacional & Externo & $\begin{array}{c}\text { Não- } \\
\text { especificado }\end{array}$ & \\
\hline Novas & 48,0 & 9,0 & 26,9 & 1,6 & 100,0 \\
Tradicionais & 58,6 & 16,2 & 15,6 & 0,0 & 100,0 \\
Dinâmicas & 46,1 & 7,6 & 29,0 & 1,9 & 100,0 \\
Amplição/M odernização & 68,6 & 15,3 & 12,5 & 0,0 & 100,0 \\
Tradicionais & 81,0 & 0,5 & 4,5 & 0,0 & 100,0 \\
Dinâmicas & 65,4 & 19,2 & 14,5 & 0,0 & 100,0 \\
\hline
\end{tabular}

FONTE: Sampaio, F. (1974, p. 86).

No momento em que foi instalado o CIA, a Petrobras constituía-se em uma grande compradora de parcela significativa da produção de algumas indústrias sidero-metalúrgicas e metalmecânicas, localizadas nesse centro industrial e na cidade do Salvador. A partir dos anos 1970, a presença da Petrobras no Recôncavo 
Baiano atrairia grandes indústrias metalmecânicas e de engenharia, exclusivamente para o fornecimento de peças e artefatos à montagem e à manutenção de plataformas marítimas, sondas, bombas e outros artefatos utilizados na prospecção, transporte e industrialização do óleo e do gás natural, demandando, assim, um aumento significativo das firmas de usinagem industrial (FEDERAÇÃO..., 1995).

Ainda na primeira metade dos anos 1970, o país estava envolto na crise de abastecimento do petróleo nacional e precisava fazer prospecções na plataforma continental; com a crise do petróleo de 1973, contudo, muitas companhias ocidentais de petróleo tiveram de buscar outras alternativas ao petróleo árabe, ocupando todas as plataformas de aluguel no Mar do Norte e na região do Alaska (MARINHO JR., 1989). Esse fato conduziu a Petrobras a fazer encomendas de plataformas de petróleo, as quais eram construídas no Brasil; algumas delas foram construídas na Bahia, por indústria instaladas no $\mathrm{ClA}$, bem como os tanques para armazenamento de óleo que eram bastante requisitados na mesma época.

Para a sidero-metalurgia do aço, com a implantação da Usina Siderúrgica da Bahia (Usiba) ${ }^{16}$, embora a Petrobras fosse um grande cliente, seu maior mercado era mesmo a indústria da construção civil, setor que demandava maior quantidade de aço, utilizado na construção civil. O mercado imobiliário da capital começava a se expandir rapidamente no início dos anos 1970. A expansão da indústria da construção civil em Salvador, especialmente, a de habitações, contribuiu também para ampliar a indústria de cimento e de minerais não-metálicos, que, dentre outras, passaram a fornecer a maior parte dos insumos, antes quase todo importado da região Sudeste (FEDERAÇÃO..., 1995).

Um desenvolvimento ainda maior no segmento metalmecânico ocorreria ao longo dos anos 1970, durante o processo de instalação do Copec, ocasionando grande demanda de vários tipos de peças e artefatos industriais e, inclusive, para sua manutenção.

As indústrias de minerais não-metálicos (cimento, cerâmica e artefatos para construção civil) produziam para o mercado regional, enquanto as indústrias químicas, classificadas no ramo das indústrias novas e dinâmicas, possuíam um mercado um pouco mais amplo, atingindo o exterior.

\section{A vez do pólo petroquímico baiano}

O CIA estava praticamente consolidado na virada para a década de 1970. Mas, por outro lado, a grande ambição industrial do Governo baiano e dos gru-

\footnotetext{
${ }^{16}$ A Usiba foi fundada em 1973, como empresa estatal pertencente ao Governo baiano, mas em 1989 foi privatizada e seu controle acionário foi adquirido pelo Grupo Gerdau. Atualmente a companhia é denominada Gerdau Usiba.
} 
pos econômicos e políticos regionais - banqueiros, grandes comerciantes e industriais -, que exerciam certa posição de destaque no estado, era a instalação de um grande complexo industrial químico, que ainda seria postergado por mais alguns anos, até que a tecnoburocracia petroleira tivesse reunido as condições para o exercício do controle no desenvolvimento desse ramo industrial no Brasil.

Esse era um pressuposto que servia de mote, tanto para evitar o monopólio das firmas estrangeiras, como para colocar em prática a própria estratégia autonomista de expansão da Petrobras. Claro estava que essa intencionalidade rebelde da tecnoburocracia do petróleo, associada a uma outra não menos importante, a do BNDE, que também já desfrutava de uma certa autonomia relativa (MARTINS, L., 1985), contrariava frontalmente a já declarada determinação política do Governo federal, pelo Decreto n 56.571, de 9 de julho de 1965 (BRASIL, 1965), de incentivar o desenvolvimento da indústria petroquímica, preferencialmente, o capital privado nacional em associação com as firmas estrangeiras.

A essa altura, os grupos regionais já conscientes do papel menor destinado ao estado da Bahia e às regiões periféricas nacionais, na nova divisão espacial da produção a partir de 1930 (GUIMARÃES, 1982; AZEVEDO, J., 1975), já estavam com os ânimos arrefecidos e integrados na nova aliança política nacional inaugurada com o movimento militar de 1964. Nesse sentido, o núcleo do grupo político baiano, liderado pelo Governo estadual, buscava colher os possíveis frutos dessa aliança.

Esse grupo político regional organizado no partido governista, a Arena, seguindo o processo de modernização conservadora, reinaugurado a partir de 1964, passou a utilizar uma tática diferente: em vez de continuar lamuriando-se pelo tratamento recebido do Governo central, requalificou os discursos e as ações, com a utilização cada vez maior do recurso do planejamento. Ao lado disso, passou a reconhecer a Petrobras como um agente aliado e não mais como adversário, isso após a empresa, entre 1968 e 1970, ter dado sinais evidentes de comprometimento com a instalação do pólo petroquímico na Bahia.

O Governo estadual liderado por Luiz Viana Filho, um arguto articulador político, invocando uma racionalidade técnica, antecipou-se ao que posteriormente seria exigido pelos burocratas do Governo federal e pelos grupos privados contrários à instalação da indústria petroquímica na Bahia - a viabilidade técnica e econômica do tal pólo petroquímico. Em 1969, o Governo baiano solicitou um estudo detalhado das possibilidades para instalação da indústria petroquímica na Bahia, seguindo uma indicação sugerida pela Missão do Banco Interamericano de Desenvolvimento (BID), da qual participava Rômulo Almeida, para promover o desenvolvimento do Recôncavo Baiano.

O projeto, desenvolvido pela empresa Consultoria e Planejamento (Clan S.A), teve o apoio financeiro da Financiadora de Estudos e Projetos (Finep), da Petroquisa 
e da Petrobras. Além disso, contou com a colaboração de figuras-chave da tecnoburocracia petroleira, do BNDE e, discretamente, do Ministro do Planejamento Reis Veloso, para não se chocar com a recusa e rejeição dos ministros: Delfim Neto, Pratini de Moraes, Dias Leite e Costa Cavalcanti.

Vê-se, dessa maneira, que havia uma solidariedade no âmbito da alta cúpula da Petrobras, do CNP, do BNDE e do CDI/Geiquim, o que contribuiu sobremaneira para desobstruir o caminho que possivelmente conduziria à instalação da indústria petroquímica na Bahia, diante das dificuldades interpostas pelas facções políticas e econômicas contrárias à realização desse projeto na Bahia. A oposição à instalação dessa indústria na Bahia possuía a seu favor o fato de ser a Bahia um estado periférico e distante do mercado de consumo, além dos interesses privados da Petroquímica União (PQU) e de demais grupos nacionais e estrangeiros que julgavam que perderiam vantagens com o pólo da Bahia.

O estudo da viabilidade econômica da indústria petroquímica na Bahia foi concluído e as negociações tiveram continuidade com o novo presidente da Petrobras, o general Ernesto Geisel, que era simpático à idéia proposta pelo grupo baiano e tinha planos próprios para a expansão comercial da companhia; e, mais que isso, tinha "carta branca" para agir. Geisel era um profundo conhecedor das questões atinentes ao petróleo, por já ter sido superintendente da refinaria de Cubatão, e também era um militar que gozava de extrema confiança do presidente General Médici. Ele assumiu o cargo com a exigência de livre ação nos projetos da empresa, pois, a partir dali, iria arquitetar sua candidatura à Presidência da República, como de fato aconteceu (MARINHO JR., 1989).

Mesmo com o estudo que apontava favoravelmente para as possibilidades de implantação da indústria petroquímica no Recôncavo Baiano e com o apoio da Petrobras à instalação do pólo na Bahia, sua concretização não se deu de maneira pacífica, pois já havia interesses privados consolidados, sendo a maioria ligada a grupos estrangeiros, como escreve Da Poian:

A inexistência de oferta de matérias-primas petroquímicas no país, a falta de uma definição clara a respeito da petroquímica [...] levou os capitais privados nacionais e estrangeiros a desenvolverem, na década de 50, alguns empreendimentos pioneiros utilizando rotas de produção não-petroquímicas. Surgiram assim: a) em 54, as fábricas de MVC e PVC a partir de acetileno obtido do carbureto de cálcio (Solvay); b) em 57, uma fábrica de estireno a partir de benzeno carboquímico e eteno obtido do álcool (Koppers/Firestone/Hulls); c) em 58, uma fábrica de polietileno de baixa densidade a partir de eteno obtido do álcool (Union Carbide); d) em 60, uma fábrica de fenol a partir de benzeno obtido na siderurgia (Burne $Y$ Borne).

Ainda em 58, a Petrobras colocou em funcionamento sua fábrica de amônia e fertilizantes, iniciou o fornecimento de eteno e propeno e deu início ao projeto da fábrica de borracha sintética [...]. As empresas estrangeiras adaptaram suas instala- 
ções para utilização de matérias-primas petroquímicas ou lançaram-se a novos empreendimentos, como uma fábrica de metanol a partir de óleo combustível (Borden Chemicals), uma fábrica de negro de fumo a partir de resíduo aromático importado (Columbia Carbo-Celanese), uma fábrica de isopropanol e acetona a partir de propeno (Rhone-Poulenc), e uma fábrica de polietileno de alta densidade (Solvay), a qual teve que recorrer ao eteno obtido do álcool devido à sua localização e à insuficiência da produção de Cubatão (DA POIAN, 1981, p. 29-30).

Mais tarde, após as devidas correções feitas pelo Governo federal na política do setor petroquímico, determinando sua exploração pela livre empresa, criou-se um ambiente político favorável à ação dessas organizações.

Para sair na frente dos negócios petroquímicos no Brasil, a firma estrangeira Union Carbide, individualmente, interessou-se em fazer investimentos numa fábrica, para processar 120 mil t/ano de eteno, em Cubatão, a partir da nafta importada; dessa produção, uma parte seria convertida em polietileno (90.000 t) para consumo próprio.

Iniciativa semelhante teve o grupo Capuava, liderado por Soares/Sampaio, um dos maiores acionistas da refinaria de petróleo Capuava e proprietário do Banco União Comercial. Com base em seu know-how no refino de petróleo, esse grupo resolveu entrar no ramo da petroquímica e, para tanto, precisava de um sócio de peso; associou-se inicialmente à Phillips Petroleum, e anexa à refinaria Capuava, de propriedade do grupo de mesmo nome, construíram uma fábrica de eteno com capacidade inicial para processar 180 mil t/ano de nafta importada; logo depois, envolveram-se no negócio o grupo financeiro Moreira Sales, o grupo Ultra e outros grupos estrangeiros, resultando na constituição da holding Unipar para controlar a emergente PQU.

O projeto da PQU era de construir uma central de matérias-primas para abastecer um conglomerado de fábricas petroquímicas, que logo passaram a se instalar em suas proximidades (DA POIAN, 1981; EVANS, 1980).

A Union Carbide, após ter realizado grande parte dos investimentos no projeto de sua Central de Matérias-Primas, desistiu do empreendimento por causa de graves falhas técnicas do novo processador industrial instalado na fábrica, tornando inviável financeiramente o seu reparo; com isso, essa empresa passou a demandar os produtos da PQU, influenciando, conseqüentemente, na ampliação desta última para atender também às necessidades da primeira. Ao mesmo tempo, a Phillips Petroleum, que também estava associada ao grupo Ultra para produção de fertilizantes (Ultrafértil), com os atrasos no desenvolvimento do cronograma desse empreendimento, implicando mais desembolsos, decidiu se retirar do projeto da PQU. Esse fato criou dificuldades orçamentárias para o grupo Soares/Sampaio e seus associados tiveram problemas para levar adiante 0 pesado encargo. 
Dessa maneira, às negociações em torno do fornecimento de nafta pela Petrobras à PQU foi adicionada a necessidade da participação da estatal no projeto da PQU, por intermédio de sua subsidiária, a Patroquisa.

A constituição da Petroquisa em 1968 ocorreu por necessidade de atender à demanda da PQU, pois esta empresa estava passando por dificuldades financeiras e não tinha como se socorrer com outros grupos privados.

Não tendo a mesma capacidade de recuperação financeira dos grupos estrangeiros, a exemplo da Union Carbide e da Phillips Petroleum, que perderam milhões de dólares em investimentos no Brasil, em conseqüência de graves falhas técnicas de seus projetos, o grupo Unipar teve de se associar à Petrobras, para dar seguimento ao projeto de desenvolvimento da Central de Matérias-primas da PQU. Todavia, essa era a parte importante de uma estratégia da Unipar para, ao mesmo tempo, ganhar posições em barganhas comerciais com grupos estrangeiros e também "[...]bloquear o projeto Petrobras/BNDE, que recomeçava a ser articulado pelas burocracias dos dois órgãos, e garantir, assim, o acesso do grupo privado aos recursos financeiros do BNDE" (MARTINS, L.; THÉRY, 1981 apud SUAREZ, 1986, p. 78).

Ao lado disso e de olho na expansão do mercado brasileiro de produtos petroquímicos, cujo consumo aparente crescia a uma taxa média anual de $246 \%$ entre 1960 e 1970 (Tabela 17), os diretores da Unipar, já cientes da intenção da Petrobras/BNDE de construir um pólo petroquímico na Bahia, contra-atacavam atraindo o apoio da Petrobras e do BNDE à criação de uma área de mercado exclusiva para os produtos da PQU e, principalmente, tentar sustar a efetivação do pólo petroquímico no Nordeste.

Tabela 17 - Brasil: consumo aparente, produção e importação (t) dos principais produtos químicos e petroquímicos - 1960/1970

\begin{tabular}{l|r|r|r|r|r|r}
\hline \multirow{2}{*}{$\begin{array}{l}\text { Classe de } \\
\text { produtos }\end{array}$} & \multicolumn{2}{c}{ Consumo aparente } & \multicolumn{2}{c|}{ Produção } & \multicolumn{2}{c}{ Importação } \\
\cline { 2 - 7 } & \multicolumn{1}{c}{1960} & 1970 & 1960 & \multicolumn{1}{c}{1970} & 1960 & \multicolumn{1}{c}{1970} \\
\hline Inorgânicos & 570.893 & 1.187 .134 & 359.730 & 965.950 & 187.699 & 221.192 \\
Fertilizantes & 298.734 & 998.566 & 126.837 & 231.950 & 13.687 & 927.020 \\
Plásticos ePlasticantes & 44.645 & 314.690 & 41.547 & 214.152 & 4.149 & 100.295 \\
Fibras sintéticas & 45.931 & 103.442 & 45.500 & 90.262 & 433 & 14.074 \\
Elastômeros e & 15.834 & 132.981 & - & 124.901 & 22.248 & 12.968 \\
Negro de Fumo & & & & & & \\
Detergentes Sintéticos & 1.374 & 21.400 & 1.374 & 21.400 & - & - \\
Solventes Orgânicos & 202 & 18.687 & 20 & 14.948 & 299 & 3.739 \\
Matérias-primas para & 1.226 & 514.343 & - & 260.600 & 1.562 & 253.743 \\
Fertilizantes Naturais & & & & & & \\
Intermediáriosem geral & 20.011 & 474.892 & 1.500 & 310.948 & 10.654 & 176.985 \\
Primários & 343.291 & 880.341 & 413.930 & 799.205 & 2.620 & 81.301 \\
\hline TOTAL & 1.342 .141 & 4.646 .476 & 990.438 & 3.034 .316 & 443.351 & 1.791 .317 \\
\hline
\end{tabular}

FONTE: Organizada por Brito (2004), com base em Instituto... (1972). 
Entre 1969 e 1970, avançavam os acertos entre a Petrobras/BNDE e a PQU, sob a fiscalização atenta de alguns ministros da República: Dias Leite (Minas e Energia), Pratini de Moraes (MIC) e Delfim Neto (Economia), que se posicionavam favoravelmente ao apoio da Petrobras à PQU. Mesmo diante da larga vantagem do apoio oficial à PQU, a tecnoburocracia petroleira e os articuladores do futuro pólo petroquímico da Bahia não se davam por vencidos. Nos bastidores, as discussões sobre o segundo pólo petroquímico seguiam celeremente e em nível de decisão: o CDI/Geiquim aprovava vários projetos petroquímicos para a Bahia e recomendava a instalação de um segundo pólo petroquímico para esse estado.

Noutra vertente, o novo presidente da Petrobras contrariando abertamente a antiga política do Governo federal e dos nacionalistas centralistas, de evitar comprar petróleo no exterior a qualquer custo, também dava sua colaboração para a implantação do pólo petroquímico na Bahia.

Sem desprezar a pesquisa do óleo no próprio país, mas, devido ao custo mais barato de sua aquisição no exterior, Geisel, em sua administração, orientava a aquisição da maior parte do óleo refinado no Brasil em fontes externas ${ }^{17}$. Não por acaso, isso também favorecia ao plano de não esgotar as limitadas reservas de óleo do Recôncavo Baiano. No mesmo sentido, Geisel deu seqüência à ampliação da RLAM (a exemplo das demais refinarias estatais), cuja capacidade de refino foi elevada de 48 mil bpd, em 1966, para 77,5 mil bpd, em 1970, com projetos de novas ampliações até 1978, para mais de 130 mil bpd, quando o pólo petroquímico da Bahia entraria em operação. Dessa maneira, a RLAM atingiria uma capacidade de refino de óleo significante para produzir matérias-primas petroquímicas em escala comercial.

A partir do início da década de 1970, os entendimentos em relação à implantação da central de matérias-primas da PQU já estavam consolidados, com a Unipar tendo subscrito $50 \%$ das ações daquela empresa, seguida da Petroquisa com $25 \%$, o grupo ULTRA com $15 \%$ e o grupo IFC com os $10 \%$ restantes (BANAS, 1972 apud EVANS, 1980); com essa distribuição acionária, a PQU entrou em operação em 1972.

Em 1970, ao ter conhecimento do assédio do governador do estado da Bahia diretamente no MIC e na presidência da República para a instalação da indústria petroquímica na Bahia, a direção da Unipar decidiu aumentar a planta da fábrica

\footnotetext{
${ }^{17}$ Numa perspectiva de expansão comercial, a Petrobras passou a adquirir a maior parte do óleo consumido no Brasil, em fontes externas. Segundo Carvalho (1977, p. 185), em 1974, apesar de a Petrobras ter atendido mais de $90 \%$ do consumo de derivados no país, somente cerca de $21 \%$ do óleo que entrava nas refinarias era produzido no Brasil. O investimento na produção (na plataforma continental onde já se tinham iniciado as pesquisas) era três vezes mais caro que o óleo importado. Mas, os dias de petróleo barato estavam contados; a partir de 1973, a OPEP elevou o preço do barril de petróleo de U\$3,05 para U\$ 11,65 em 1974, aumentando bruscamente a dependência brasileira do petróleo estrangeiro.
} 
de eteno da PQU, de 180 para 300 mil toneladas/ano, o que, conseqüentemente, inviabilizaria economicamente as pretensões originadas em torno do pólo petroquímico baiano, em decorrência do controle de mercado exercido pela PQU.

O projeto de ampliação da planta industrial da PQU e o projeto de criação de um segundo pólo petroquímico na Bahia geraram no ambiente governamental federal uma acirrada disputa de posições entre o grupo Unipar e o Governo baiano, cada um apresentando a defesa da viabilidade técnica e econômica de seus respectivos projetos. Depois de dois meses, o apoio ao segundo pólo petroquímico foi deferido pelo Governo federal. Porém, somente em maio de 1970, durante uma visita ao estado da Bahia, é que o presidente Médici declarou-se publicamente a favor da posição do Governo baiano. Para isso, foi fundamental o comprometimento da Petrobras com a construção da Central de Matérias-Primas e a execução de obras de ampliação da RLAM para o fornecimento de:

[...] 300 mil t/ano de eteno, 202 mil t/ ano de propeno, 52 mil t/ano de butadieno, 126 mil t/ano de benzeno [...]. Haveria também uma Central de Utilidades e outra de Manutenção e Serviços, que dariam a Camaçari condição singular no Brasil (VIANA FILHO, 1984, p. 45-46).

Após várias ações protelatórias acolhidas pelos ministros pró-PQU, a decisão final da implantação do segundo pólo petroquímico somente sairia em 1971, depois do resultado de um novo estudo contratado pelo MIC para avaliar a viabilidade técnica e econômica da instalação do segundo pólo petroquímico na Bahia. A pesquisa apenas confirmou os resultados do estudo anterior realizado pela Clan, em 1969 (VIANA FILHO, 1984; SUAREZ, 1986).

Durante esse período, o grupo Unipar obteve várias autorizações para fazer ampliações nas plantas industriais da PQU e de demais empresas sob seu controle acionário no pólo de São Paulo. Ironicamente, esses custosos investimentos da Unipar a envolveram em graves dificuldades financeiras, em decorrência de não mais contar com o apoio financeiro do grupo Ultra, que havia se retirado logo no início da constituição da holding e de estar acumulando prejuízos, pela "[...] inadequação do preço final dos produtos petroquímicos e seus custos [...]" (O QUE..., 1974, p. 20) pela ação rígida do Conselho Interministerial de Preços (CIP) de tentar conter a inflação.

Diante da dificuldade, a alternativa encontrada pela Unipar para cobrir as despesas na PQU e ampliar a planta industrial do pólo de São Paulo foi recorrer inicialmente ao Banco União Comercial (BUC), de propriedade do grupo Unipar. Como não havia cobertura dos créditos tomados ao banco, este faliu e os prejuízos financeiros da Unipar continuaram se acumulando (STUMPF; PEREIRA FILHO, 1979). A saída para a crise financeira da Unipar foi negociar o controle acionário da PQU 
com a Petroquisa, em 1973. Assim que a Petroquisa assumiu a PQU o “[...] preço do etileno sofreu imediata quadruplicação por simples decisão dos diretores [...]" (O QUE..., 1974, p. 20). Em 1974, a Petroquisa já possuía 64,4\% do capital votante da PQU (O QUE..., 1974).

No pólo petroquímico de São Paulo, apesar de a Petroquisa deter o controle acionário da PQU, existiam outras empresas de capital nacional associadas ao capital estrangeiro que agiam de maneira quase autônoma. Essa ação autônoma, ao que tudo indica, não agradava à tecnoburocracia petroleira, como comenta um importante ex-executivo dessa tecnoburocracia: "Na consolidação do pólo de São Paulo lançaram-se, portanto, as bases, sem regras claras ainda definidas, para a convivência do Estado com a iniciativa privada nacional e estrangeira" (DA POIAN, 1981, p. 32).

A quase liquidação do outrora vigoroso grupo Unipar pela tecoburocracia petroleira e a assunção legal da distribuição das matérias-primas petroquímicas serviram de aviso aos demais grupos empresariais privados que pretendiam agir autonomamente no não menos importante mercado brasileiro de produtos petroquímicos e derivados. Como pode ser mensurado pelos dados da Tabela 17, o mercado brasileiro de produtos petroquímicos se alargava ano a ano, com base na nova matriz industrial inaugurada com o "Plano de Metas" e que, por sua vez, ganhava maior impulso durante a fase do "Milagre Econômico".

Historicamente, grande parte dos grupos empresariais privados nacionais e estrangeiros via o crescimento do SPE como algo sempre inoportuno. Esses grupos ainda não haviam descoberto uma das formas de ação do Estado, por meio do SPE, o qual, de maneira contraditória e funcional, se empenhava em realizar objetivos microeconômicos associados a interesses macroeconômicos e, a partir disso, viabilizava a reprodução do capital privado em escala ampliada. Mas, os que, apesar das desconfianças, perceberam a longa e segura estrada preparada pelo SPE, para o desenvolvimento de um específico processo de reprodução do capital na petroquímica (CÁRIO, 1997), aproveitaram as vantagens de estar associados ao SPE e desfrutaram das benesses que lhes eram concedidas (ARAÚJO; DICK, 1974; DA POIAN, 1981).

O estudo realizado por Araújo e Dick (1974) sobre as empresas do Copec aponta para uma remuneração enormemente vantajosa dos capitais privados em associação com a Petroquisa.

Os autores identificaram que, para os capitais nacionais, em sua maioria, de pouca tradição no setor petroquímico, a participação acionária efetivamente de risco era de menos de $5 \%$, e magicamente via empréstimos, financiamentos e subsídios junto ao Governo federal, se transformava em 1/3 do total dos capitais nos empreendimentos de segunda geração, pelo artifício do modelo tripartite da composição do capital das empresas. 
Para os capitais estrangeiros, as vantagens advinham do desimpedimento das transações entre a matriz no exterior e sua participação nas empresas daquele pólo: licenciamento de patentes, comercialização de produtos em mercados distintos, facilidades de remessas de lucros etc.; o sócio estatal, que a título de arcar com maiores custos durante a instalação do empreendimento, ao final também colhia os respectivos lucros; tinha acesso à tecnologia e processos sempre atualizados pela presença de técnicos estrangeiros nas fábricas, treinamento de técnicos brasileiros nas fábricas das empresas estrangeiras, acesso a "dinheiro novo, em moeda forte", e acesso a mercados estrangeiros, por conta da participação do sócio estrangeiro.

A despeito dos enormes subsídios econômicos oferecidos pelo Governo federal (Art. 34/18 da Sudene), das linhas de financiamento do BNDE, dos benefícios cedidos pelo Governo baiano e do acesso fácil e seguro às fontes de matériasprimas regionais, de custo inferior a uma localização no eixo São Paulo/Rio de Janeiro, o fator determinante para a consolidação do projeto do Copec foi, sem dúvida, a adoção da fórmula política de organização das empresas, segundo o modelo tripartite, já em operação no pólo de São Paulo.

Em novembro de 1972 foi constituída a Companhia Petroquímica do Nordeste (Copene), uma subsidiária da Petroquisa que assumiria a Central de MatériasPrimas, a Central de Utilidades e a Central de Manutenção. Ainda no fim desse ano, teve início o processo de organização das empresas de segunda e terceira gerações e os respectivos formatos para operação no Copec.

No projeto de organização das empresas de produtos de segunda geração, funcionou o modelo tripartite de participação acionária, cuja base era formada por 2/3 de capital nacional (1/3 privado e 1/3 estatal), e a participação do SPE não poderia ser inferior a qualquer uma das outras duas partes, e 1/3 estrangeiro. Essas organizações também ficariam obrigadas a adquirir participação acionária na Copene, como uma maneira encontrada pela estatal para garantir o compromisso com o empreendimento, o que era essencial para as três partes, principalmente para Copene (ARAÚJO; DICK, 1974).

Quando a Copene foi constituída, a participação da Petroquisa não era inferior a 51\%, mas cinco anos depois de plena operação, em 1983, esta detinha $48,16 \%$ do capital votante daquela empresa, e estava presente diretamente em 12 das 30 empresas que faziam parte do Copec; operava também em outras empresas por meio de suas coligadas e da própria Copene (BACCARIO, 1983).

Para a Copene, a vantagem advinha do fato de essa empresa ter garantido os usuários dos produtos básicos e dos serviços oferecidos por suas Centrais de Matérias-Primas, de Utilidades e de Manutenção; para os particulares, a vantagem adivinha de poder contar com o fornecimento contínuo de insumos e estar presente nas decisões daquela empresa, que afetaria todo o Copec. Já para as 
empresas que lidavam com produtos finais a participação do SPE era minoritária e/ou não existia. As empresas que operavam principalmente no setor de produtos de terceira geração e posteriores nessa época tinham maior participação de capitais nacionais, especialmente os regionais, como o grupo econômico liderado por Clemente Mariani (Banco da Bahia Investimentos e da Companhia de Seguros da Bahia), fundador da empresa Petroquímica da Bahia - uma holding que controlava mais cinco companhias no Copec (DA POIAN, 1981; BACCARIO, 1983); o grupo Econômico e o grupo Odebrecht, que encontraram seus devidos lugares nas diversas indústrias petroquímicas com as quais se associaram (DA POIAN, 1981) e, em especial, o último que, associado ao grupo Mariani, adquiriu o controle acionário da Copene, em 2002, quando essa estatal foi privatizada e passou a chamar-se Braskem - que, por sua vez, tem o controle acionário da Companhia Petroquímica do Sul (Copesul) e de várias outras companhias petroquímicas distribuídas em distintas partes do mundo. ${ }^{18}$

A associação entre os grupos econômicos regionais Odebrecht e Mariani resultou na aquisição de quase $50 \%$ do capital votante da Braskem; esse grupo controla também a Norquisa, além de possuir participações acionárias menores em outras empresas do Copec (DA POIAN, 1983).

O balanço dos episódios da instalação do CIA e depois do Copec serve para ilustrar o processo de organização e reprodução de um território no Recôncavo Baiano, a RPBA, sob a liderança da Petrobras, a partir da segunda metade dos anos 1960. Para tanto, foram envolvidos os agentes regionais outrora contrários às ações até então implementadas no Recôncavo Baiano pela Petrobras.

A liderança exercida pela Petrobras no processo de industrialização da Bahia e o abandono de ações unilaterais, ainda na primeira parte dos anos 1960, foram os elementos que alçaram a companhia para a posição de hegemonia em relação aos demais agentes sociais (seus interlocutores) no Recôncavo Baiano.

Durante esse período, pode-se afirmar que a Petrobras foi capaz de construir um território novo no Recôncavo Baiano, e ao mesmo tempo, induzir um processo de transformações fundamentais na estrutura social, política, econômica e territorial que, associado a outros vetores internos e externos, transbordou para além dos limites de seu território no Recôncavo Baiano. Contudo, a construção desse território pela Petrobras não se deu de maneira aleatória, mas sim combinando seus interesses diretos com os interesses dos demais agentes envolvidos, resultando no processo de gestão do território. Cumpre destacar que a gestão empreendida pela companhia no Recôncavo Baiano é anterior à formação desse território, remonta ao seu próprio processo de inserção e desenvolvimento de suas atividades.

\footnotetext{
${ }^{18}$ A Copesul foi criada em junho de 1976 para operar como uma Central de Matérias-Primas e de Serviços para o Pólo Petroquímico do Rio Grande do Sul, no município de Triunfo.
} 


\section{A Petrobras e o processo de reorganização territorial no Recôncavo Baiano}





\section{A Petrobras e o processo de reorganização territorial no Recôncavo Baiano}

Neste capítulo, busca-se discutir em que condições e como a Petrobras implementou o processo de gestão de seu território no Recôncavo Baiano a partir de sua inserção na Bahia. Pretende-se esclarecer também qual a extensão e de que maneira as relações entre a companhia e os demais agentes sociais em torno da produção e da industrialização do petróleo e do gás natural provocaram implicações na configuração desse território e, por fim, apresentar a respectiva configuração espacial contemporânea do Recôncavo Baiano.

A passagem do General Ernesto Geisel pelo comando gerencial da Petrobras, de 1969 a 1973, foi marcada por uma intensa expansão organizacional e comercial da companhia. A tecnoburocracia petroleira que assumiu a direção da Petrobras junto com Geisel, cujo sentido empresarial era muito mais agressivo que o de sua antecessora, caracterizado por uma ação mais centralista e governamental, foi responsável pela condução da empresa ao processo de conglomeração organizacional.

A nova tecnoburocracia petroleira não se contentava somente em cumprir as determinações circunscritas ao monopólio estatal do petróleo. Dentro do exercício do monopólio do petróleo, a nova direção da companhia buscava sempre, por todos os meios, a maximização de lucros, os quais constituíam a fonte de sua autonomia em relação ao Governo.

Estava evidente que, levada pelo interesse microeconômico de sua tecnoburocracia, a Petrobras sempre se empenhava para atingir a liderança comercial em todos os setores da economia do petróleo no Brasil e, inclusive, no exterior, com o desenvolvimento de serviços de prospecção e produção de óleo e gás, venda de serviços e de tecnologia etc. A razão e a necessidade para que esse intento pudesse prosseguir sem interrupções e/ou sem obstáculos de ordem financeira e/ou organizacional, levaram os dirigentes da companhia a adotar uma política de maior agressividade microeconômica, combinando diversificação e ampliação dos investimentos em vários setores econômicos ligados ao petróleo.

Para tanto, a companhia teria que passar por uma nova e importante reformulação organizacional adotando, dessa vez, a forma conglomerada, implementada ao longo dos anos 1970. Esse formato de estrutura organizacional, além de garantir o reforço no caixa, dada sua potência no processo de geração e acumulação de lucros, servia também para qualificá-la como uma grande corporação, durante as negociações com outras companhias e Governos, com os quais a Petrobras se relaciona comercialmente. 
Dessa maneira, ciente da impossibilidade de atingir a auto-suficiência em petróleo extraído do subsolo brasileiro e diante do desígnio da companhia, de suprir o mercado nacional de todo o óleo necessário ao seu consumo, que crescia em ritmo acelerado, dado o grau elevado de crescimento econômico do país na era do "milagre econômico", Geisel, apoiado pela tecnoburocracia petroleira, retomou o processo de reestruturação organizacional da empresa. A transformação da Petrobras em uma grande corporação de petróleo, tal qual suas congêneres - Ente Nazionali Idrocarburi (Eni), da Itália; British Petroleum (BP), da Inglaterra; Petróleos Mexicanos (Pemex), do México; dentre outras - e as grandes corporações privadas, possibilitou à estatal buscar atingir a auto-suficiência em produtos derivados do petróleo produzidos internamente.

O processo de transformação da Petrobras em uma grande corporação de petróleo iniciou-se após a criação da Petroquisa (química) em 1968, prosseguiu com a criação da BR Distribuidora (venda ao consumidor), em 1971, seguida da fundação da Braspetro (ação internacional), em 1972, da Petrofértil (fertilizantes), em 1973, da Interbras (comércio e serviços no exterior), em 1976, e da Petromin (mineração), em 1977.

Como prática comum às grandes corporações, as transformações na estrutura organizacional da Petrobras desenvolveram-se num continuum, pela busca da superação de possíveis dificuldades que surgiram no processo de geração e acumulação de riqueza no interior da organização. Dessa maneira, já nos anos 1970 a companhia tinha adotado uma estrutura organizacional multidivisional, formada com seis subsidiárias. Esse fato implicou uma impressionante robustez funcional e de lucratividade, cujo resultado mais palpável emergiu logo nos albores da década de 1980, como um conglomerado de empresas de ação internacional e de grande complexidade - uma grande corporação típica.

As transformações na estrutura organizacional da Petrobras prosseguiram até atingir a forma atual composta pela própria holding que opera as refinarias de petróleo, pela Petroquisa (ramo químico), pela Braspetro (ação internacional), pela Transpetro (transporte), BR Distribuidora (varejo de combustíveis e lubrificantes), pela Gaspetro (gás), pela Fafen (ex-Petrofértil - fertilizantes) e pelo Centro de Pesquisas e Desenvolvimento (Cenpes).

Em 2001 a Petrobras foi classificada pela Revista Fortune, como a nona maior companhia de petróleo do mundo e no ranking geral era a $160^{\mathrm{a}}$ maior companhia. Ao final do exercício de 2000, a Petrobras possuía 133 mil acionistas, 13 refinarias, 38.908 empregados e apresentou o lucro líquido de $\mathrm{R} \$ 10$ bilhões (cerca de U\$ 4,25 bilhões); esse desempenho financeiro significou um novo recorde na história da companhia.

A natureza estatal da Petrobras, associada ao cunho gerencial nacionalista e centralista adotado desde sua fundação, em 1954, implicou atraso no início das 
transformações em sua estrutura organizacional, precisamente de onze anos para a implantação, em 1965, da estrutura organizacional departamentalizada e, de dezoito anos para a criação da primeira subsidiária - a Petroquisa. Essas transformações iniciais foram incentivadas pelo próprio Governo federal, a fim de evitar o aumento dos gastos públicos com o oneroso financiamento da companhia; as mudanças organizacionais seguintes, que transformaram a companhia numa grande corporação, ocorreram à revelia do Governo. Tais mudanças foram comandadas pela própria tecnoburocracia corporativa, diante do grau elevado de autonomia financeira e gerencial adquirido pela corporação ao longo do tempo.

O atraso histórico é bem maior se comparar o início do processo de mudanças na estrutura organizacional da Petrobras com o das grandes corporações, em especial as norte-americanas, que efetivamente passaram a adotar tais mudanças organizacionais desde antes da Segunda Guerra Mundial, como sublinha Chandler (1998). Grande também é a diferença de tempo entre essas companhias que passaram a realizar investimentos diretos no estrangeiro já no pós-Guerra e a Petrobras; esta somente passou a fazê-los no início dos anos 1970, com a criação da Braspetro, para produzir e adquirir petróleo no exterior.

Trata-se por grandes corporações, as grandes empresas estatais e/ou privadas, sejam elas denominadas multinacionais, transnacionais e internacionais. A categoria empresa multinacional é muito controversa e se está longe de se chegar a um consenso.

Para Hymer (1978, p. 54) "[...] as empresas multinacionais são instituições privadas que organizam uma ou poucas indústrias em muitos países". Essa definição limita a complexidade imanente dessas organizações, pois ela não contempla as organizações controladas ou mantidas pelo Estado, as quais agem da mesma maneira que as grandes corporações privadas: a Petrobras é um exemplo evidente disso.

Estudo realizado por Anastassopoulos; Blanc; Dussauge (1985) concluiu que a categoria "empresa multinacional" não é exclusiva das organizações privadas, como defendem os pesquisadores norte-americanos que estudam essas categorias de empresas, algumas organizações estatais também podem ser multinacionais; como exemplo, os autores citam a Petrobras. No exterior, por meio de suas subsidiárias a Petrobras se associa a outros grupos empresariais privados e/ou estatais para operar na produção, transporte e industrialização do óleo e do gás etc.

As empresas multinacionais, como são conhecidas atualmente, encerram um conceito cercado de interesses político, econômico e ideológico, principalmente nos EUA, onde tiveram origem e exercem grande influência no Governo. Por isso mesmo, grande parte dos autores (a maioria norte-americanos) tem uma tendência a se referir quase que exclusivamente às firmas de capital privado. $O$ pro- 
cesso que envolve apropriação, reprodução/gestão de uma fração do espaço geográfico ou de um dado território não constitui obra de exclusividade de empresas internacionais. As empresas nacionais também cumprem bem esse papel; e a parte do espaço geográfico ou o território onde elas se inserem tem tanta visibilidade quanto a importância da respectiva corporação em sua perspectiva de ação no mercado mundial, determinada pela lógica complexa da acumulação capitalista.

Apesar de, na maioria das vezes, serem compreendidas de modo monolítico, as corporações agrupam, em sua rede corporativa várias organizações que agem de maneira quase independentes, do ponto-de-vista de suas formas de gerenciamento interno e de relacionamentos com o mercado, mas, no fim, são controladas por uma empresa holding, que determina e centraliza o processo de produção e de acumulação de capital, como esclarece Mandel (1985, p. 164) ao afirmar que a "[...] atividade de investimentos nessas várias fábricas ou oficinas da mesma empresa depende de uma decisão central, e não da decisão de diretores das unidades isoladas".

Na busca pela compreensão da lógica da divisão interempresarial da produção e da acumulação capitalista no interior das grandes corporações, e do consequente processo de organização do espaço geográfico produzido pelas ações dessas companhias, Taylor; Thrift (1983) propõem a abordagem da segmentação das grandes corporações.

Taylor; Thrift (1983), com base, principalmente, nos conceitos da abordagem ambiental, do grupo de pesquisadores de Aston, e da abordagem da estrutura organizacional das grandes corporações, desenvolveram a teoria da segmentação das organizações aplicada à geografia econômica.

A formulação de Taylor; Thrift (1983) fundamenta-se na existência de várias empresas de natureza diferente, pertencentes a uma grande corporação. Essas distintas empresas operam conectadas em rede a uma holding. A segmentação ocorre pela função que cada empresa ou divisão desempenha, segundo sua classificação em: leaders, em geral, correspondem aos centros de pesquisa e desenvolvimento das grandes corporações, intermediates - são as empresas essenciais à geração da maior parte da riqueza produzida pela corporação; elas agem, principalmente, no fornecimento de produtos ou serviços de primeira linha e mais rentáveis -, laggards - são as empresas que operam no fornecimento de produtos ou serviços de tecnologia já consolidada; mas, mesmo assim, essas empresas continuam sendo importantes no processo de geração de lucros da grande corporação - e de support - são empresas que operam no fornecimento de serviços de apoio ao desenvolvimento da própria corporação.

Para os referidos autores, a estrutura organizacional multidivisional e multilocalizada, adotada pelas grandes firmas, constitui uma importante estraté- 
gia de ação para lidar com as atividades meio e fim, diante da concorrência intercapitalista, na escala mundial. Essa estratégia foi sumamente importante para as grandes corporações em fins dos anos 1960, na tentativa de superação da grave crise econômica mundial e sua posterior reestruturação, nos anos 1970. Durante esse período, as grandes corporações apresentaram uma significativa expansão em termos de tamanho e quantidade e se espalharam por amplas partes do globo (TAYLOR; THRIFT, 1986).

Nesse sentido, seja qual for a categoria e a natureza das grandes empresas, sejam elas de controle estatal e/ou privado, essas organizações são permeadas pelo know-how universal do capitalismo, em função de empregarem tecnologia atualizada, obterem financiamento de várias fontes nacionais e internacionais, almejarem o mercado mais amplo possível e buscarem lidar com produtos ou parte de produtos mundiais, dado o forte grau de "universalização da mercadoria" promovida pela padronização que, dentre outras questões da lógica dos negócios, é determinada pela necessidade de produção em larga escala e em múltiplos lugares, em conseqüência da busca pela redução de custos e controle de áreas de mercado.

A análise das ações da Petrobras numa parte do Recôncavo Baiano implica pensar em sua gestão desse território, desenvolvida com base nas intenções e nas necessidades corporativas, segundo um conjunto de normas gerais e específicas reguladoras das ações dos agentes sociais. A gestão do território é, ao mesmo tempo, condição e necessidade do processo de inserção da companhia no Recôncavo Baiano e do posterior desenvolvimento de sua reprodução, por meio de suas estratégias e ações.

Com base em Tzu (2001), entende-se a noção de estratégia como um conjunto de possibilidades, por meio das quais os agentes sociais buscam auferir vantagens em face de contingências surgidas em sua trajetória.

As ações praticadas pela Petrobras ao longo do tempo, numa parte do Recôncavo Baiano, têm por finalidade torná-la cada vez mais funcional e integrada às demandas diretas e indiretas, presentes e futuras da companhia e/ou de outros agentes para ali atraídos, ou seja, essa porção do espaço geográfico temse tornado cada vez mais corporativa (SANTOS, M., 1993; LOJKINE, 1981).

Apesar de o termo gestão, management, ser de difícil definição, sua análise é deveras importante, devido à sua utilidade para os propósitos deste livro. O termo gestão é usualmente empregado pela ciência da administração no sentido da realização de ações teleológicas, implementadas por um corpo administrativo empresarial e/ou não-empresarial envolvendo meios e fins.

Nesse sentido, a gestão vincula-se às ações sistemáticas da alta gerência das organizações e/ou dos Governos, segundo princípios científicos, para conduzi-los na trajetória de seus objetivos, dentro de uma perspectiva de eficiência previsivel. 
Vista como processo, em face das contingências do mundo real, a gestão é exercida essencialmente por tomada de decisões, antes políticas que técnicas, na busca por erigir e/ou conservar posições convenientes aos agentes sociais interessados, como destaca Reed (1997, p. 80):

O trabalho de gestão sofre uma metamorfose conceitual, surgindo como uma prática social que se acha inevitavelmente envolvida, de forma profunda e resistente, em negócios pouco claros, [...], que perante os conflitos e tensões potencialmente ameaçadores das suas bases materiais e culturais, ajudam a manter as estruturas de poder [...].

Dessa maneira, fica claro que o conteúdo político é determinado pela própria natureza das escolhas de estratégias apropriadas às tentativas de superar as incertezas no desenvolvimento dos objetivos das organizações, as quais têm origem tanto em seu interior, como no ambiente externo.

É nesse sentido, que se entende o termo gestão, como tarefa desenvolvida por um agente social que, por meio de determinadas estratégias, busca dirimir os conflitos e/ou superar os obstáculos à sua frente, tornando as contingências menos aleatórias e, portanto, mais determináveis diante dos seus objetivos. A gestão envolve ações sociais que não se pautam somente em decisões técnicas e nem pela neutralidade política. O conteúdo técnico da gestão é apenas instrumental e é concebido ao nível do planejamento, o qual faz parte de outras instâncias de status inferiores à de tomada de decisões.

Por ser instrumental, o planejamento apenas legitima a tomada de decisões que é, por natureza, política. Logo, há uma clara distinção entre gestão e planejamento conforme sugere também Machado (1995). Contrariamente à proposição de Becker $(1988$, p. 4) para quem "[...] a gestão é a prática estratégica, científico-tecnológica do poder no espaço [...]", pode-se afirmar ainda que, seja qual for a situação, o processo de gestão, que é desenvolvido num continuum, não se acha determinado por nenhum conteúdo científico, técnico ou tecnológico, ainda que se sirva desses. Acima de tudo, porém, a natureza da gestão é essencialmente política.

Dessa maneira, a gestão de uma dada porção do espaço geográfico e/ou de um território por uma grande corporação significa a gestão da reprodução das diferenças dos conteúdos de distintas partes de uma mesma matriz espacial. Essa gestão se baseia nas práticas espaciais desenvolvidas pelos agentes sociais com o fim de, segundo seus interesses, dar sentido ao processo de reprodução das condições de produção atuais e futuras (CORRÊA, 1992). Para Marx $(1988$, p. 659) "[...] todo processo social de produção encarado em suas conexões constantes e no fluxo contínuo de sua renovação, é ao mesmo tempo processo de reprodução." Isso implica que a gestão, ou seja, as decisões de como desenvolver melhor o processo de reprodução dos interesses de dados agentes 
em suas múltiplas conexões possibilita a produção futura em nível sempre mais avançado.

No processo de gestão do espaço geográfico torna-se mister frisar que a implementação dos interesses de um dado agente em relação aos demais, com os quais se relaciona em uma dada porção do espaço geográfico, não necessariamente envolve consenso; depende, em primeira instância, da vontade do agente que possui maior vigor, o qual poderá ou não utilizar recursos que servem exclusivamente a seus interesses, dessa maneira, precisamente aqui, utiliza-se o termo espaço geográfico. De outra maneira, o termo território será utilizado, exclusivamente, quando constituído por relações pactuadas entre os agentes interessados por um objeto circunscrito numa dada porção do espaço geográfico.

É por meio do processo de gestão de partes do espaço geográfico e/ou de territórios que os distintos agentes, sobretudo as grandes corporações, que se inserem nessas categorias espaciais e/ou que têm pretensão de fazê-lo, pautam suas estratégias de ação em relação aos conteúdos de parcelas do espaço geográfico e/ou territórios e também em seu exterior.

Assim, diante da complexidade e da instabilidade do mundo real, a abordagem contingencial das organizações, desenvolvida entre os anos 1950 e 1960, busca superar os problemas gerados pela rigidez da forma clássica de gestão das organizações, pensadas, até então, como elementos isolados do ambiente. Essa abordagem considera as organizações como sistemas abertos, sujeitos a influenciar e a serem influenciados pelas variáveis do ambiente exterior à firma (MORGAN, 1996; CLARKE, 1985; HALL, 1984).

Na lógica de compreensão da abordagem ambiental da ciência da administração, o ambiente é composto pelas seguintes variáveis: tecnológicas, legais, políticas, econômicas, demográficas, ecológicas, sociais e culturais. O ambiente é ainda dividido em geral (nacional e supranacional) e de operações (local); as variáveis ambientais são comuns a ambos.

Para dar consecução às suas intenções de instalar unidades comerciais e/ou produtivas em dadas partes do espaço geográfico mundial, as grandes corporações consideram as seguintes condições: a magnitude e o grau de qualificação e politização da força de trabalho; a escala de oferta de insumos, de sua qualidade e origem; o tamanho e as especificidades do mercado de consumo das mercadorias e dos fornecedores de insumos; a logística de apoio governamental, jurídico e financeiro; a infraestrutura física disponível - transportes, telecomunicações, energia elétrica, abastecimento de água e terrenos para expansão, dentre outras (OFFNER; PUMAIN, 1996).

Assim, a alta gerência da Petrobras, ao decidir instalar unidades da empresa no Recôncavo Baiano, certamente considerou o conjunto de condições indispensáveis ao progresso das atividades inerentes às grandes empresas, em uma dada localização. Porém, como tudo indica, a condição essencial para a inserção 
da Petrobras no Recôncavo Baiano foi, sem dúvida, a grande oferta de matériaprima (petróleo e gás natural) disponível. As demais condições foram sendo providenciadas pela própria companhia, a exemplo de uma indústria de artefatos para petróleo, estradas, outros meios de comunicação, que quando existiam eram precárias e/ou muito limitadas, sem falar da técnica e da força de trabalho qualificada necessários à operação dos processos industriais da companhia.

Até os anos 1960, o Recôncavo Baiano não se constituía em um meio inovador, fecundo para as atividades da Petrobras a jusante e a montante dos campos de petróleo e de gás natural; ou seja, o Recôncavo Baiano, nessa época, constituía-se, de maneira predominante, num "espaço opaco" (SANTOS, M., 1994). O surgimento de "espaços luminosos" no Recôncavo Baiano deve-se, sobretudo, à ação objetiva emanada pelas atividades da Petrobras, associada aos demais interlocutores regionais, nacionais e estrangeiros.

\section{A reprodução dos "espaços luminosos" e dos "espaços opacos" no Recôncavo Baiano}

Como elementos que agem influenciando direta e indiretamente no processo de reprodução do capital em estágios sempre mais avançados, as grandes corporações e suas subsidiárias se constituem em empresas-rede, em decorrência de suas demandas e da escala de operações.

O termo empresa-rede é retirado de Offner; Pumain (1996), no sentido da maximização da integração espacial/territorial e da centralização do capital, no âmbito da rede da grande corporação. As empresas-rede cumprem papel fundamental no processo de gestão de parcelas do espaço geográfico ou dos territórios. A conformação do espaço geográfico ou do território subjacente a esse tipo de empresa ampara-se em apoios de toda ordem - institucional, político, jurídico, cultural, empresarial etc. Esses tipos de empresas são capazes de criar e/ou induzir a criação, a transformação e/ou a ampliação de um sistema de infraestrutura de apoio logístico para dar suporte ao desenvolvimento de suas ações no local e nas adjacências onde elas executam suas operações.

Como função da enorme escala de operações e das diferentes demandas em seus processos de produção, as grandes corporações também conseguem atrair para sua órbita um pool de numerosos agentes de naturezas distintas, para, a partir das relações entre si, ao mesmo tempo, beneficiarem-se e fornecerem apoios diretos e indiretos às ações desses grupos empresariais, em porções do espaço geográfico e/ou território, nos quais algumas de suas unidades estão inseridas.

A Petrobras, ao se instalar no Recôncavo Baiano, desde os tempos do CNP, também deu início ao seu processo de gestão sobre o seu ambiente de opera- 
ções. O processo de gestão espacial desenvolvido pela Petrobras nesta região pode ser mensurado, de um lado, pela nova sistemática da organização do trabalho e pelo sistema de produção, em fluxo contínuo, de natureza mais técnica e em bases contratuais. Por outro lado, a própria matriz industrial/técnica e sua correspondente escala de produção, introduzida pela companhia, implicou uma transformação profunda na base técnico-econômico-produtiva que, transbordou também para os setores social e cultural.

O processo de gestão do território pela Petrobras, no Recôncavo Baiano, a partir da segunda metade da década de 1960 ocorre inicialmente sobre aquele outro que se encontrava em fase de quase dissolução, pela extrema fragilidade em que as relações de poder entre os agentes subsistiam, até fins dos anos 1950; em seguida a gestão é implementada num novo território que foi erigido sobre as cinzas do anterior.

A gestão do território pela Petrobras, teve destacada relevância, em decorrência da existência de petróleo e gás natural em profusão. Essas duas matérias-primas são relativamente escassas e se acham associadas a atributos especiais (energia e combustíveis que movimentam fábricas, hospitais, veículos civis e militares etc.) para os Estados e para as grandes corporações que detêm partes significativas de suas reservas. Tais matérias-primas são de suma importância para a produção de uma infinidade de produtos, de ampla aceitação no mercado mundial.

Isso implica a atenção à lei do desenvolvimento desigual e combinado do capitalismo que orienta, sobretudo, as grandes corporações a se inserirem em porções do espaço geográfico e/ou territórios e a os reproduzir ignorando, em maior ou menor grau, a vida de relações sociais, culturais e de produção historicamente existentes, movidas por temporalidades próprias.

Da interação entre a novidade que chega, veiculada principalmente pelas redes das grandes corporações, e o antigo, já consolidado, que se dá em níveis variados de resistências, ganha força a emergência de frações do espaço geográfico que podem ser mais ou menos favoráveis ao processo de reprodução ampliada do capital. A essas porções do espaço geográfico, Santos, M. (1994) denomina de espaços luminosos - subespaços ativos e também funcionais à acumulação capitalista - e, de espaços opacos, os fragmentos do espaço geográfico mais ou menos desprezados pelos agentes capitalistas maiores; estes subespaços, entretanto, também são funcionais no processo universal de reprodução da riqueza no sistema capitalista, pela natureza complementar e seletiva da exclusão social, econômica e cultural de dadas partes do espaço geográfico, mas que, em ocasiões distintas, segundo condições históricas específicas, podem se alterar ao serem seletivamente incorporados na engrenagem do sistema capitalista de produção e de valorização das mercadorias.

Essas categorias espaciais refletem o grau de desenvolvimento das forças produtivas e da respectiva divisão espacial do trabalho em um país, região ou territó- 
rio. Dessa maneira, quanto mais desenvolvida se encontra a divisão do trabalho numa dessas categorias espaciais, maior é a visibilidade das diferenças entre as funções realizadas e as distintas configurações espaciais (MARX; ENGELS, 1984).

No Recôncavo Baiano, a reprodução dessas duas categorias espaciais - "espaços luminosos e espaços opacos" - é nítida e ambas podem ser mensuradas pelas diferenças de níveis de organização e funcionalidade das atividades econômicas, dos níveis desiguais de desenvolvimento social e da concretização do fenômeno próprio da urbanização que se processam ao longo do tempo.

A nova configuração espacial no Recôncavo Baiano da segunda metade dos anos 1960 resulta da implementação do processo de criação e de gestão do território pela Petrobras, por meio de suas práticas espaciais as quais não atingiram a região por inteiro, não tiveram a mesma intensidade e nem ocorreram ao mesmo tempo. Em outras palavras, ao longo do tempo, as ações da Petrobras em inter-relação com as ações dos demais agentes regionais, nacionais e internacionais no Recôncavo Baiano deram-se de maneira seletiva temporal e espacialmente. Esse processo ensejou, nos tempos atuais, a consolidação de duas unidades espaciais distintas, e a sua compreensão está ligada ao processo histórico de intervenção dos agentes sociais (BROWETT, 1984) interessados pelo petróleo e pelo gás natural existentes no subsolo de uma parte do Recôncavo Baiano e pela emplementação das atividades econômicas em torno dessas matérias-primas.

As duas unidades espaciais (Quadro 2) são as seguintes: a antiga Região de Produção da Bahia (RPBA) e o Recôncavo "canavieiro/fumageiro".

Quadro 2 - Municípios que compõem a RPBA e o Recôncavo “canavieiro/fumageiro" - 2000

\begin{tabular}{|l|l|}
\hline \multicolumn{1}{|c|}{ RBPA } & \multicolumn{1}{|c|}{ Recôncavo “Canavieiro/Fumageiro” } \\
\hline $\begin{array}{l}\text { Alagoinhas, Araçás, Camaçari, Candeias, Cardeal } \\
\text { da Silva, Catu, Dias D’Ávila, Entre Rios, Esplanada, }\end{array}$ & $\begin{array}{l}\text { Amélia Rodrigues, Aratuípe, Cachoeira, Conceição } \\
\text { da Feira, Conceição do Almeida, Conceição do }\end{array}$ \\
Ita-nagra, Itaparica, Lauro de Freitas, Madre de & Jacuípe, Cruz das Almas, Dom Macedo Costa, Go- \\
Deus, Mata de São João, Pojuca, Salvador, São & vernador M angabeira, Jaguaripe, M aragogipe, \\
Francisco do Conde, São Sebastião do Passé, & $\begin{array}{l}\text { Muniz Ferreira, Muritiba, Nazaré, Salinas da M arga- } \\
\text { rida, Santo Amaro, Santo Antônio de Jesus, São }\end{array}$ \\
& $\begin{array}{l}\text { Felipe, São Félix, São Gonçalo dos Campos, Sapeaçu, } \\
\text { Saubara, Teodoro Sampaio, Terra Nova e Varzedo. }\end{array}$ \\
\hline
\end{tabular}

FONTE: Pesquisa do autor.

Atualmente, a Petrobras deu nova denominação à antiga RPBA: Exploração \& Produção (E\&P-BA) abrange a Bacia Sedimentar do Recôncavo/Tucano/Jatobá, as demais bacias sedimentares fora do Recôncavo Baiano e a plataforma continental. Para se manter uma diferenciação espacial e baseando-se no próprio processo histórico, será mantida aqui a antiga denominação - RPBA. Da mesma maneira, para a zona "canavieira e fumageira", em termos econômicos, já não tem muito sentido manter essa denominação, em virtude da produção de açúcar e de 
fumo nessa área não ser mais importante economicamente, mesmo assim será conservada com base nos elementos históricos subjacentes aos aspectos da cultura, da economia e da sociedade regionais.

A RPBA é composta por vinte municípios, inclusive Salvador e dela fazem parte municípios que compõem as regiões econômicas e funcionais: Metropolitana de Salvador e Litoral Norte, nas quais, são desenvolvidas as operações de produção propriamente ditas - prospecção, extração, transporte e industrialização do óleo e do gás natural, bem como de seus derivados - e as funções de coordenação das atividades da companhia e de suas subsidiárias e coligadas que se encontram instaladas exclusivamente na cidade de Salvador. A RPBA constitui uma secção da matriz geográfica maior, que é o Recôncavo Baiano.

Contíguo à RPBA, localiza-se o Recôncavo "canavieiro/fumageiro", com 25 municípios, constituído por municípios integrantes das regiões econômicas: Recôncavo Sul e Paraguaçu. Nesse conjunto de municípios, atualmente, nenhuma atividade econômica se encontra ligada à produção de óleo e de gás natural e nem à sua industrialização; contudo, era de alguns deles, sobretudo dos municípios canavieiros, que saía uma parte considerável da força de trabalho para constituir o exército industrial de reserva à disposição da Petrobras, até por volta da primeira metade dos anos $1960 .^{1}$

\footnotetext{
1 Segundo os dados do Censo Agropecuário da Bahia, de 1950, existiam três municípios que se destacavam como grandes produtores de cana-de-açúcar para usinas: Santo Amaro (470.870t), São Sebastião do Passé (138.000t) e São Francisco do Conde (93.336t), com uma produção total de 702.206t. Já em 1996, data do último Censo Agropecuário, os dados sobre a produção de cana-de-açúcar propriamente para usina registram um acréscimo de apenas $8.3 \%$ (760.320t) na produção total, mesmo diante de toda a evolução tecno-científica voltada para essa atividade, ocorrida ao longo de quatro décadas.
}

O que é relevante frisar é que a área de produção canavieira restringiu-se aos atuais municípios de Amélia Rodrigues, que produz sozinho 76\% (541.110t), e Santo Amaro, com mais 24\% (172.587t), cuja produção é processada por apenas uma grande usina de açúcar - a Aliança, localizada em Santo Amaro; as terras de outras duas usinas (Paranaguá (Santo Amaro) e Itapetingui (Amélia Rodrigues)), paralisadas em 2000 e 2001, respectivamente, cumprem a função de fornecimento de cana-de-açúcar àquela usina. Nos demais municípios da mesma área onde havia usinas, as quais foram desativadas há mais tempo, suas terras, entre $20 \%$ e $46 \%$ dos estabelecimentos agropecuários, são utilizadas para criação de gado semi-extensiva.

Entre os municípios onde predominava a fumicultura, como lavoura comercial, cuja produção total foi de 6.404t em 1950, destacam-se Cachoeira, Conceição da Feira, Cruz das Almas, Maragogipe, Muritiba, Santo Amaro, Santo Antônio de Jesus, São Félix, São Felipe e São Gonçalo dos Campos, esta em 1996 diminuiu para menos de 1/4 (1.521t) da produção total. Em 1996, os municípios de Muritiba (37\%) e Governador Mangabeira (29\%) produziram juntos 997 de fumo, dentre os demais se destacam: Sapeaçu (9\%), Gonçalo dos Campos (8\%), São Felipe (6\%), Conceição do Almeida (5\%), os demais tiveram produção inexpressiva. Nesse último período, os municípios de Conceição da Feira e São Gonçalo dos Campos, respectivamente, 40\% e 46\% dos estabelecimentos agropecuários estavam ocupados com criação de gado. 
Do sistema de gestão e organização do território implementado pela Petrobras, no conjunto da área que abrange a RPBA e o Recôncavo "canavieiro/fumageiro", pode-se destacar a ocorrência simultânea de três práticas espaciais diferentes e complementares, a saber: seletividade espacial, reprodução da região produtora e antecipação espacial. ${ }^{2}$

Os princípios da seletividade espacial - uma das primeiras práticas espaciais desenvolvidas pela Petrobras no Recôncavo Baiano - foram orientados pela abundância das matérias-primas existentes nos terrenos da Bacia Sedimentar do Recôncavo, que se prolonga até a Bacia Sedimentar Tucano/Jatobá, na parte mais ao Norte e exterior do Recôncavo Baiano. A descoberta dos campos de petróleo e de gás natural nessa área e sua posterior exploração deu origem à RPBA.

Na década de 1950, em virtude de o Recôncavo Baiano ser a única província petrolífera brasileira, a companhia decidiu localizar uma sede administrativa regional na cidade do Salvador, por meio da qual são coordenadas todas as tarefas e decisões da companhia, executadas regionalmente, abrangendo as mesorregiões Norte e Nordeste do Brasil. Na época, a cidade do Salvador, habitada por pouco mais de 420 mil pessoas, era o único núcleo urbano no estado da Bahia em condições de atender às demandas corporativas da Petrobras.

Como metrópole regional, descrita por Santos, M. (1959b), a cidade do Salvador dispunha de um grande porto marítimo, junto ao qual se consolidou o Central Business District (CBD) desde o século XIX. Nessa cidade, a companhia tinha acesso a vários tipos de serviços urbanos de apoio empresarial, bem como usufruía das possibilidades dos contatos face a face com as demais empresas fornecedoras e compradoras de produtos e serviços. Ao lado disso, a companhia também podia ter acesso a outros interlocutores localizados fora da área central, a exemplo da Universidade da Bahia, de colégios de ensino técnico e profissionalizante de nível médio, além da própria indústria mecânica, localizada na antiga zona industrial da cidade - na Península de Itapagipe até os anos 1960. ${ }^{3}$

Para se evitar problemas futuros de congestionamento e obsolescência da infraestrutura urbana na área central da cidade, a instalação da sede regional da

\footnotetext{
${ }^{2}$ Corrêa (1992) explica, com o exemplo do grupo econômico Souza Cruz, como as grandes corporações, na busca por aumentar seus níveis de lucratividade e expansão comercial, desenvolvem algumas práticas espaciais tais como: seletividade espacial, fragmentação e remembramento espacial, antecipações espaciais, marginalidade espacial e reprodução de regiões produtoras.

${ }^{3}$ Em fins dos anos 1960, a maior parte das indústrias existentes na cidade de Salvador passou a se localizar no CIA e no Distrito Industrial Urbano (Dinurb), estabelecido em Salvador ao longo da rodovia BR-324.
} 
Petrobras em Salvador já surgiu descentralizada - na zona periférica do centro, contígua à feira de Água de Meninos, na Avenida Jequitaia.

Contemporaneamente, a cidade do Salvador destaca-se em relação às demandas corporativas da Petrobras, em virtude de sediar seus escritórios e os de algumas de suas subsidiárias, por meio dos quais pode centralizar e coordenar, no âmbito regional, as diversas tarefas da companhia e de suas empresas subsidiárias e das coligadas. Essa função de gerência também se aplica às empresas industriais que possuem fábricas no CIA e no Copec, bem como a outras empresas comerciais e industriais que possuem escritórios na capital baiana.

A partir dessa localização central e dispondo das redes técnicas - malha rodoviária, dutoviária e de telecomunicações - rapidamente implantadas em sua área de operações, ainda nos anos 1960, a companhia integra territorialmente todos os campos de petróleo e gás natural e suas unidades processadoras, indústrias, bases de suprimentos de matérias-primas e derivados (porto do Temadre), e escritórios, seletivamente distribuídos em seu território, no Recôncavo Baiano e noutras partes localizadas nas regiões Norte e Nordeste do Brasil.

Por sua vez, ligada diretamente à produção, foi construída a refinaria, no município de São Francisco do Conde. Essa unidade industrial localiza-se a jusante dos campos de petróleo e gás, na borda da Baía de Todos os Santos, formando uma área de porto natural, relativamente afastada de núcleos de povoamento por motivo de segurança e dispondo de área suficiente para ampliações.

Noutra parte, distante cerca de quatro quilômetros da RLAM, foi construído o porto-terminal de óleo e derivados (Temadre), na ilha de Madre de Deus, um dos limites extremos do município de Salvador até 1989, quando foi transformada em município. Na opinião dos técnicos da companhia, essa localização, para os respectivos empreendimentos, era a mais recomendada, devido às facilidades de recebimento e expedição de materiais para a construção de ambos e das matérias-primas, utilizando-se o transporte de cabotagem na Baía de Todos os Santos e, além disso, a própria condição de segurança do complexo industrial-portuário petrolífero também recomendava essa localização.

Já no município de Camaçari, em fins dos anos 1960, a corporação construiu o Copeb que antecedeu o Copec, onde foi instalada uma fábrica para produção de fertilizantes nitrogenados, utilizando o gás natural como matéria-prima, abundante nos campos da Petrobras na RPBA. Essa iniciativa se deu visando a antecipação de interesses de se utilizar o gás natural na fabricação de produtos petroquímicos já reclamados por seus interlocutores regionais, tendo em vista a Petrobras estar interessada em desenvolver e controlar a exploração desse ramo industrial no Brasil. Com essa medida, já se tem presente também a antecipação espacial como uma prática das grandes corporações. 
A refinaria, o terminal marítimo de petróleo e derivados, além das fábricas localizadas no Copeb, as subsidiárias da companhia, a sede regional da corporação e a rede de dutos e estradas asfaltadas instaladas na RPBA pela própria empresa constituem os maiores e mais importantes elementos dos "sistemas de objetos" (SANTOS, M., 1997) exclusivos da Petrobras e operados pela companhia na RPBA. Afora esses equipamentos há também, em vários outros municípios - Camaçari, Candeias, Catu, Entre Rios, São Sebastião do Passé e São Francisco do Conde - junto aos grandes campos de petróleo e gás natural, bases, atualmente denominadas Núcleos de Produção (Nupro), compostas pelas unidades processadoras de gás natural in locu; centrais de acumulação e expedição de óleo e de gás natural, para a refinaria e para o Copec, por meio de oleodutos e gasodutos; galpões para armazenamento de máquinas e equipamentos; oficinas, alojamentos e refeitórios; núcleos de treinamento profissional e escritórios, destinados ao controle diário das operações de produção de óleo e de gás executadas localmente.

Dos Nupros a companhia monitora os vários campos de produção sob as respectivas áreas de ação de cada um deles, que abrange mais de um campo de exploração situado em um mesmo município. Atualmente há cerca de oitenta campos de exploração de petróleo e de gás natural na bacia do Recôncavo, com centenas de poços produtores (AGÊNCIA..., 2003).

Todas essas unidades de operação são interligadas por meio de redes de estradas asfaltadas, de sistemas de telecomunicações, de redes de dutovias e ainda por uma estrada de ferro pré-existente. Para a conexão das unidades de operações com a sede regional da companhia, na cidade do Salvador, a empresa utiliza-se das estradas e dos sistemas de telecomunicações, especialmente a telefonia e a rede intranet.

Os investimentos econômicos da Petrobras no Recôncavo Baiano certamente induziram outros agentes, em especial o Governo baiano, a planejar a criação de uma base de sinergias econômicas com os investimentos regionais dessa companhia.

Em consequência disso, o Governo baiano decidiu construir, em fins dos anos 1960, o ClA, nos municípios de Candeias e Simões Filho, ambos contíguos a Salvador. Os parâmetros balizadores para essa localização foram: a proximidade com a refinaria da Petrobras, para obtenção de matérias-primas derivadas do petróleo a custos mais baixos e a acessibilidade portuária (o porto de Aratu construído também em fins dos anos 1960, no município de Candeias), para a recepção de matérias-primas e insumos importados de outras regiões do Brasil e do exterior, bem como, a exportação das mercadorias produzidas localmente. Para isso, definiu-se que o CIA seria instalado numa área, ao mesmo tempo próxima da refinaria e também de uma zona portuária, entre os municípios de Candeias e Simões Filho. 
Já a decisão de localização do pólo petroquímico da Bahia foi tomada pela própria tecnoburocracia petroleira e comunicada ao Governo baiano, para providência das medidas legais e econômicas necessárias à execução do projeto.

Em vez de construir o pólo petroquímico na área do CIA, como desejava o Governo estadual, inclusive por motivos econômicos decorrentes da existência de uma ampla infraestrutura industrial e, também, onde já estavam em funcionamento algumas grandes indústrias químicas, entre as quais se destacava a Dow Química uma empresa multinacional, a tecnoburocracia da Petrobras preferiu fazê-lo noutra área, junto ao Copeb. Esse empreendimento foi organizado exclusivamente pela Petrobras e pelo BNDE para a produção de fertilizantes, iniciada no fim dos anos 1960.

Tal decisão, como explica Suarez (1986), deveu-se a uma forma de represália da tecnoburocracia petroleira contra a Dow Química, em virtude de esta empresa pretender ser autônoma na produção de produtos petroquímicos no Brasil. Considerando essa conjuntura, a localização do pólo petroquímico baiano, nas proximidades de onde estava instalada a fábrica da Dow Química, resultaria em vantagens para aquisição dos insumos básicos produzidos pela Central de MatériasPrimas da Copene, uma subsidiária da Petroquisa, o que não era do desejo da tecnoburocracia petroleira.

Excetuando-se as vinculações de ordem corporativa, de participação acionária, a Petrobras também tem estreitas ligações com as indústrias localizadas no Copec e, em parte, das que se instalaram no CIA (químicas e siderúrgicas). As vinculações da Petrobras com essas indústrias ocorrem pelo motivo de fornecimento de insumos - nafta, gasóleo, gás natural e outras matérias-primas petroquímicas. Dada a proximidade da refinaria e dos campos de gás, em relação a esses dois núcleos industriais localizados na Região Metropolitana de Salvador (RMS), os insumos fornecidos pela Petrobras são transferidos da RLAM e dos campos de gás natural, com grande segurança e economia, por meio de oleodutos, gasodutos, caminhões e trem.

As ações da Petrobras, que resultaram na antecipação espacial e na seletividade espacial dos investimentos da corporação no Recôncavo Baiano, também condicionaram a criação das possibilidades para o desenvolvimento concomitante de uma terceira prática espacial - reprodução da região produtora. Essa foi se materializando com a ampliação dos investimentos da corporação e dos demais agentes ao longo do tempo.

Ainda como parte do processo de gestão do território pela Petrobras, começou a se estruturar na RPBA um agrupamento de núcleos urbanos, que possui vínculos muito próximos com a Petrobras e com as demandas organizadas em torno da pesquisa e produção de óleo e gás natural nos campos da RPBA. 
Muitos desses núcleos urbanos oferecem uma base de apoio logístico às operações das unidades da própria corporação e das firmas que a ela prestam serviços, seja simplesmente pelo aluguel de residências e/ou fornecimento de alimentação aos trabalhadores, ou ainda pelo suprimento de parte das necessidades das operações diárias da Petrobras, das empresas terceirizadas e das empresas que executam diretamente nas próprias operações de pesquisa e produção de óleo e gás natural. A partir de 1997 a Petrobras perdeu o monopólio estatal do petróleo.

Nas cidades mais importantes da RPBA, a Petrobras e as demais firmas do setor petrolífero e de apoio buscam a utilização de serviços: bancários, judiciários, de segurança, transporte, manutenção de equipamentos, máquinas e veículos, alimentação, compras de materiais e outras especialidades ou atividades comuns às demandas de operações locais.

As cidades da RPBA também são importantes às atividades dessa corporação, por serem local de residência de 96\% dos 5.051 funcionários diretos em atividade na RPBA, em 20004. Nesse ano, em Salvador, residiam $74 \%$ dos funcionários e, entre as outras cidades onde habitam funcionários da Petrobras, dezessete cidades ao todo, distribuem-se $22 \%$ do pessoal da companhia; dentre essas cidades, sobressaem-se Alagoinhas e Catu onde residia a maior quantidade funcionários, após Salvador; os outros $4 \%$ se distribuíam em várias localidades fora da RPBA como é evidenciado na Tabela 18, onde a cidade de Feira de Santana reunia 125 funcionários diretos da corporação.

Quanto à produção, em 1999, dos 4.977 funcionários diretos da Petrobras em serviço na RPBA, 83\% ocupavam-se nas unidades localizadas fora de Salvador; nessa situação, destacavam-se os municípios de São Francisco do Conde, onde está localizada a refinaria e, por isso, ocupa uma numerosa força de trabalho (32\%), e Catu, que sedia um dos mais importantes Nupros da RPBA, denominado Água Grande (Tabela 18). Situação semelhante, mas em menor escala, é verificada para as demais empresas que operam na extração de petróleo e gás natural na RPBA; mais uma vez a cidade de Catu mostra-se relevante para as atividades de produção de óleo e gás natural. A cidade de Catu, seguida por Salvador, Simões Filho e Pojuca servem de base de operações para outras empresas que mantêm $875,428,11$ e 6 funcionários, nessa ordem, conforme os dados da RAIS (BRASIL, 2000).

\footnotetext{
${ }^{4}$ Em estudo de tese de doutorado em 1972 sobre Les migrations pour le reconcave du petroleo, quando teve acesso ao fichário dos empregados da empresa, Silva, M. contabilizou cerca de 16.000 funcionários diretos ligados às atividades da Petrobras no Recôncavo Baiano, por volta de 1970.
} 
Tabela 18 - Local de residência dos funcionários da Petrobras em serviço na RPBA - 1999

\begin{tabular}{|c|c|c|c|c|c|}
\hline \multirow{2}{*}{ Cidades } & \multicolumn{2}{|c|}{ Funcionários } & \multirow{2}{*}{ Cidades } & \multicolumn{2}{|c|}{ Funcionários } \\
\hline & Total & $\%$ & & Total & $\%$ \\
\hline Salvador & 3.742 & 74,1 & Feira de Santana & 125 & 2,5 \\
\hline Alagoinhas & 451 & 8,9 & Santo Amaro & 41 & 0,8 \\
\hline Catu & 180 & 3,6 & Amélia Rodrigues & 10 & 0,2 \\
\hline São Sebastião do Passé & 96 & 1,9 & Aramari & 7 & 0,1 \\
\hline Lauro de Freitas & 85 & 1,7 & Cruz das Almas & 3 & 0,0 \\
\hline Candeias & 79 & 1,6 & Serrinha & 3 & 0,0 \\
\hline Pojuca & 51 & 1,0 & Terra Nova & 3 & 0,0 \\
\hline São Francisco do Conde & 38 & 0,8 & Cachoeira & 2 & 0,0 \\
\hline Madre de Deus & 28 & 0,6 & Conceição do Jacuípe & 2 & 0,0 \\
\hline Camaçari & 23 & 0,5 & Muritiba & 2 & 0,0 \\
\hline Mata de São João & 20 & 0,4 & Inhambupe & 2 & 0,0 \\
\hline Dias D'A vila & 15 & 0,3 & Conceição da Feira & 1 & 0,0 \\
\hline Simões Filho & 14 & 0,3 & Governador $M$ angabeira & 1 & 0,0 \\
\hline Entre Rios & 12 & 0,2 & Irará & 1 & 0,0 \\
\hline Esplanada & 4 & 0,1 & Maragogipe & 1 & 0,0 \\
\hline Cardeal da Silva & 2 & 0,0 & Mutuípe & 1 & 0,0 \\
\hline Itaparica & 2 & 0,0 & Riachão do Jacuípe & 1 & 0,0 \\
\hline Araçás & 1 & 0,0 & Santa Bárbara & 1 & 0,0 \\
\hline- & - & - & São Gonçalo dos Campos & 1 & 0,0 \\
\hline Total da RPBA & 4.845 & - & Total das outras áreas & 206 & - \\
\hline
\end{tabular}

TOTAL GERAL

5.051

FONTE: Organizada por Cristóvão Brito, a partir dos dados cedidos pela assessoria de comunicação da Petrobras. Dado numérico arredondado, inferior a 0,1.

A Lei n 9.478, de agosto de 1997 (Lei do Petróleo), permite a participação de outras empresas na produção de petróleo e de gás natural no Brasil. Assim, em fins da década de 1990, algumas empresas de petróleo passaram a explorá-lo nos "campos maduros" - campos que possuem baixo volume da produção de óleo, não sendo de interesse imediato das grandes empresas, mas é operado por empresas menores - e em novos campos descobertos no Recôncavo Baiano. Em 2000 já havia quatro firmas, associadas ao capital multinacional, operando na RPBA e mais uma se instalou em 2003; as quatro primeiras possuem escritórios nas cidades de Mata de São João, Catu, Lauro de Freitas e Simões Filho e a última em Aracaju-SE. Segundo reportagem de $A$ Tarde (A BAHIA..., 2001), essas empresas possuem unidades de apoio localizadas nas respectivas cidades, bem como recrutam sua força de trabalho e buscam serviços de outras firmas localizadas em suas proximidades.

A gestão e reprodução do território da Petrobras no Recôncavo Baiano implicou a segmentação funcional, econômica, produtiva e social desta região, fazendo emergir duas áreas distintas: o Recôncavo "canavieiro/fumageiro" e a RPBA. 
Tabela 19 - RPBA: Local de trabalho dos funcionários da Petrobras - 1999.

\begin{tabular}{|c|c|c|}
\hline \multirow{2}{*}{ Municípios } & \multicolumn{2}{|c|}{ Funcionários } \\
\hline & Total & $\%$ \\
\hline São Francisco do Conde & 1.601 & 32,2 \\
\hline Salvador & 843 & 16,9 \\
\hline Catu & 687 & 13,8 \\
\hline São Sebastião do Passé & 614 & 12,3 \\
\hline Camaçari & 511 & 10,3 \\
\hline Candeias & 314 & 6,3 \\
\hline Entre Rios & 204 & 4,1 \\
\hline Madre de Deus & 203 & 4,1 \\
\hline TOTAL & 4.977 & 100,0 \\
\hline
\end{tabular}

FONTE: Organizada por Brito, a partir dos dados cedidos pela assessoria de comunicação da Petrobras em 1999.

\section{A indústria de transformação como fator de produção de "espaços luminosos" e de "espaços opacos"}

Tomando-se a indústria de transformação como medida relativa de progresso econômico, numa economia de base agromercatil-financeira, em declínio acentuado, verifica-se, de acordo com os dados referentes a essa indústria, que ao longo das décadas de 1960 e 1970 a economia baiana deu passos largos e importantes, na direção de sua integração funcional ao centro da economia nacional, cuja consolidação aconteceu nos períodos posteriores. Esse fato implicou um processo de descolamento da economia baiana, das atividades agromercatil-financeiras, inserindo-se na economia nacional, por meio de uma política governamental de industrialização induzida pela Sudene, seguindo um modelo de crescimento econômico, de base industrial e urbana.

Os dados do censo industrial de dezembro de 1959 do estado da Bahia indicam que as indústrias de transformação, de modo geral, produziram em conjunto U\$ 88.647.975,00 referentes ao VTI e, na média, o grau de extração de mais-valia foi 3,8. Com as mudanças substanciais ocorridas na economia baiana, ao longo das décadas de 1960 e de 1970, promovidas pela Sudene e por outras agências de fomento econômico, principalmente, a partir da entrada em operação das indústrias do CIA e do Copec e das ampliações executadas na RLAM, ao longo desse período, esses números foram ampliados respectivamente para U\$ 2.698.090.229,00 referentes ao VTI e 5,8 de mais-valia na década de 1980 (Tabela 20). 
Tabela 20 - Bahia: extração de mais-valia na atividade industrial - 1960, 1980 e 2000

\begin{tabular}{l|c|c|c|c|c|c|c|c}
\hline Período & $\begin{array}{c}\text { Unidades } \\
\text { locais }\end{array}$ & $\begin{array}{c}(\mathrm{A}) \\
\text { Pessoal } \\
\text { ocupado }\end{array}$ & $\begin{array}{c}(\mathrm{B}) \\
\text { Salários } \\
(\mathrm{U} \$)\end{array}$ & $\begin{array}{c}\text { Valor da Transfor- } \\
\text { mação Industrial }(\mathrm{U} \$)\end{array}$ & $\begin{array}{c}(\mathrm{D}) \\
\begin{array}{c}\text { Média } \\
\text { salário/ano } \\
(\mathrm{B} / \mathrm{A})\end{array}\end{array}$ & $\begin{array}{c}(\mathrm{E}) \\
\text { Riqueza/ } \\
\text { funcionário } \\
(\mathrm{C} / \mathrm{A})\end{array}$ & $\begin{array}{c}(\mathrm{F}) \\
\begin{array}{c}\text { Mais-valia } \\
\text { (absoluto) } \\
(\mathrm{E}-\mathrm{D})\end{array}\end{array}$ & $\begin{array}{c}(\mathrm{G})(2) \\
\begin{array}{c}(2) \\
\text { ais-valia } \\
(\text { relativo }) \\
(\mathrm{F} / \mathrm{D})\end{array}\end{array}$ \\
\hline 1960 & 5.950 & 50.023 & 18.591 .886 & 88.647 .975 & 371,7 & $1.772,1$ & $1.400,5$ & 3,8 \\
1980 & 12.671 & 133.514 & 398.051 .619 & 2.698 .090 .229 & $2.981,3$ & $20.208,3$ & $17.226,9$ & 5,8 \\
2000 & 14.124 & 134.107 & 628.518 .721 & $\ldots$ & $4.686,7$ & $\ldots$ & $\ldots$ & $\ldots$ \\
\hline
\end{tabular}

FONTE: Organizada por Brito (2004), com base em IBGE $(1966,1984)$.

Salário médio mensal: U\$31, em 1960, e U\$248, em 1980 e, \$ 412, em 2000. Obtém-se o salário médio mensal dos funcionários dividindo-se os valores da coluna D por 12 (doze meses). (2) Para $G=1$, a extração da mais-valia é $100 \%$..... Dado numérico não disponível.

O índice representado pela mais-valia constitui um parâmetro relativamente consistente, por meio do qual se pode aferir indiretamente a evolução dos padrões de desenvolvimento das técnicas e métodos de produção na indústria, considerando-se também os padrões salariais nacionais e/ou regionais vigentes.

O índice de mais-valia é uma função do valor da transformação industrial e do montante de salários pagos para produzi-la; ele oferece uma medida da evolução da produtividade do trabalho, que é tanto maior quanto melhores e mais avançadas forem as técnicas e métodos de produção, os quais implicam o grau elevado de extração de mais-valia da força de trabalho.

Para o período referente ao recenseamento de 2000, as informações são incompletas; contudo, indicam um certo progresso no setor industrial baiano, de acordo com o aumento dos números para as variáveis divulgadas, principalmente os salários pagos aos trabalhadores.

Os dados acusam uma surpreendente recuperação setorial da economia baiana, indústria de transformação, embora ainda distante do volume de riqueza gerado no centro nacional mais dinâmico, representado pelo estado de São Paulo.

O VTI gerado pelas unidades industriais instaladas na Bahia atingiu apenas 4,4\%, em 1960, e 6,8\%, em 1980, do VTI gerado nas fábricas localizadas no estado de São Paulo. Quanto ao grau de extração de mais-valia na atividade industrial, no estado de São Paulo, este índice foi de 2,8, em 1960, e de 14,8, em 1980 (Tabela 21).

Tabela 21 - São Paulo: extração de mais-valia relativa na atividade industrial - 1960, 1980 e 2000

\begin{tabular}{|c|c|c|c|c|c|c|c|c|}
\hline Período & $\begin{array}{l}\text { Estabele- } \\
\text { cimentos }\end{array}$ & $\begin{array}{l}\text { (A) } \\
\text { Funcio- } \\
\text { nários }\end{array}$ & $\begin{array}{c}\text { (B) } \\
\text { Salários } \\
(U \$)\end{array}$ & $\begin{array}{c}\text { (C) } \\
\text { Valor da } \\
\text { Transformação } \\
\text { Industrial (U) }\end{array}$ & $\begin{array}{c}(\mathrm{D})^{(1)} \\
\text { Média } \\
\text { salário/ano } \\
(\mathrm{B} / \mathrm{A})\end{array}$ & $\begin{array}{c}(\mathrm{E}) \\
\text { Riqueza/ } \\
\text { funcionário } \\
(\mathrm{C} / \mathrm{A})\end{array}$ & $\begin{array}{c}(\mathrm{F}) \\
\text { Mais-valia } \\
\text { (absoluto) } \\
\text { (E/D) }\end{array}$ & $\begin{array}{c}(\mathrm{G})^{(2)} \\
\text { Mais-valia } \\
\text { (relativo) } \\
\text { (F/D) }\end{array}$ \\
\hline $\begin{array}{l}1960 \\
1980\end{array}$ & $\begin{array}{l}36.254 \\
62.426\end{array}$ & $\begin{array}{r}831.339 \\
2.287 .045\end{array}$ & $\begin{array}{r}519.255 .434 \\
2.567 .720 .413\end{array}$ & $\begin{array}{r}1.994 .807 .010 \\
39.875 .970 .725\end{array}$ & $\begin{array}{r}624,6 \\
1.122,7\end{array}$ & $\begin{array}{r}2.399,5 \\
17.435,6\end{array}$ & $\begin{array}{r}1.774,9 \\
16.312,9\end{array}$ & $\begin{array}{r}2,8 \\
14,5\end{array}$ \\
\hline 2000 & 136.575 & 2.150 .647 & 14.037 .150 .588 & $\ldots$ & $6.526,9$ & $\ldots$ & $\ldots$ & $\ldots$ \\
\hline
\end{tabular}

FONTE: Organizada por Brito (2004), com base em IBGE $(1966,1984,2002)$.

Salário médio mensal: U\$52, em 1960, e U\$276, em 1980 e, U\$544, em 2000. Obtém-se o salário médio mensal dos funcionários dividindo-se os valores da coluna D por 12 (doze meses). (2) Para $G=1$, a extração da mais-valia relativa é $100 \%$.... Dado numérico não disponível. 
O maior índice de extração de mais-valia apresentado pelas indústrias localizadas na Bahia, em relação ao alcançado pelas indústrias do estado de São Paulo, em 1960 decorre dos salários mais baixos percebidos pelos operários baianos, cujo valor alcançava, em média, $60 \%$, no mesmo período, aumentando bruscamente para $265,4 \%$, em 1980 , e diminuindo em seguida para $76 \%$, em 2000 , em relação aos salários dos operários do estado de São Paulo.

Enquanto o salário mínimo mensal oficial em vigor em Salvador e no municípios adjacentes era de U\$26,7, em 1960, U\$ 155,9, em 1980, e U\$ 82,5, em 2000, conforme dados do Anuário Estatístico do Brasil, os operários empregados nas industrias instaladas na RPBA percebiam, em média, U\$ 48,7, U\$ 415,4 e U\$ 780 , nos respectivos períodos. A partir de 1988, o salário mínimo deixou de ser regionalizado e sua vigência passou a ser nacional.

Na época da realização da pesquisa do Censo Industrial de 1960, que ocorreu em 1959, a indústria de transformação no estado da Bahia ainda não tinha experimentado as mudanças ensejadas pelo apoio financeiro da Sudene a partir de 1960. Esse fato se reflete no baixo nível de geração de riqueza nesse tipo de indústria, fortemente vinculada às matérias-primas de origem agropecuária e ainda utilizava processos de produção e equipamentos predominantemente arcaicos.

Contudo, nesse contexto, destaca-se a indústria do petróleo, que já surge avançada nos aspectos tecnológico e gerencial, contribuindo para ampliar a geração de riqueza e incrementar o padrão de extração de mais-valia na indústria de transformação. Para o período posterior a década de 1960, não se pode perder de vista que as grandes indústrias localizadas no CIA e no Copec, bem como as unidades de produção da Petrobras, eram tão intensivas em capital quanto suas congêneres localizadas no estado de São Paulo.

Em 1960, o conjunto de indústrias de transformação localizado no Recôncavo "canavieiro/fumageiro", na RPBA e no município de Salvador foi responsável pela geração de 49,4\% do VTI do estado da Bahia, indicando, assim, uma forte concentração industrial nessa parte do estado. Dessa massa de riqueza, as indústrias localizadas na cidade do Salvador produziram a maior parte, 52,3\%; a RPBA, $35 \%$ e o Recôncavo "canavieiro/fumageiro", apenas 12,7\%.

Em relação à extração de mais-valia relativa na atividade industrial, o município de Salvador e o conjunto dos municípios que compõem a RPBA, superam, de longe, o Recôncavo "canavieiro/fumageiro; este com 1,7, a RPBA (sem o município de Salvador) com 4,5 e o município de Salvador exclusivamente com 3,4 (Tabelas 22, 23 e 24).

A proporção de geração de riqueza na indústria de transformação, localizada na mesma área, foi ampliada de 49,4\% em 1960 para 86\%, em 1980, em relação ao conjunto do estado da Bahia. 
Tabela 22 - Salvador: extração de mais-valia relativa na atividade industrial - 1960, 1980 e 2000

\begin{tabular}{|c|c|c|c|c|c|c|c|c|}
\hline Período & $\begin{array}{l}\text { Estabele- } \\
\text { cimentos }\end{array}$ & $\begin{array}{l}\text { (A) } \\
\text { Funcio- } \\
\text { nários }\end{array}$ & $\begin{array}{l}(B) \\
\text { Salários } \\
(U \$)\end{array}$ & $\begin{array}{l}\text { (C) } \\
\text { Valor da Transforma- } \\
\text { ção Industrial (U\$) }\end{array}$ & $\begin{array}{c}\text { (D) }{ }^{(1)} \\
\text { Média } \\
\text { salário/ } \\
\text { ano(B/A) }\end{array}$ & $\begin{array}{c}\text { (E) } \\
\text { Riqueza/ } \\
\text { funcionário } \\
(\mathrm{C} / \mathrm{A})\end{array}$ & $\begin{array}{c}(F) \\
\text { Mais-valia } \\
\text { (absoluto) } \\
\text { (E/D) }\end{array}$ & $\begin{array}{c}(\mathrm{G})^{(2)} \\
\text { Mais-valia } \\
\text { (relativo) } \\
(\mathrm{F} / \mathrm{D})\end{array}$ \\
\hline & & $\begin{array}{l}12.413 \\
26.517\end{array}$ & $\begin{array}{r}5.201 .625 \\
76.160 .462\end{array}$ & $\begin{array}{r}22.894 .827 \\
367.954 .743\end{array}$ & $\begin{array}{r}419,0 \\
2.872,1\end{array}$ & $\begin{array}{r}1.844,4 \\
13.876,2\end{array}$ & $\begin{array}{r}1.425,4 \\
11.004,0\end{array}$ & $\begin{array}{l}3,4 \\
3,8\end{array}$ \\
\hline 2000 & 2.688 & 32.641 & 205.840 .394 & $\ldots$ & $6.306,2$ & $\ldots$ & $\ldots$ & $\ldots$ \\
\hline
\end{tabular}

FONTE: Organizada por Brito (2004), com base em IBGE (1966, 1984, 2002).

(1) Salário médio mensal: U\$35, em 1960, U\$239, em 1980 e, U\$ 526, em 2000. Obtém-se o salário médio mensal dos funcionários dividindo-se os valores da coluna $D$ por 12 (doze meses). (2) Para $G=1$, a extração da mais-valia relativa é $100 \%$... Dado numérico não disponível.

Tabela 23 - Recôncavo "canavieiro/fumageiro": extração de mais-valia relativa na atividade industrial 1960,1980 e 2000

\begin{tabular}{|c|c|c|c|c|c|c|c|c|}
\hline Período & $\begin{array}{l}\text { Estabele- } \\
\text { cimentos }\end{array}$ & $\begin{array}{l}\text { (A) } \\
\text { Funcio- } \\
\text { nários }\end{array}$ & $\begin{array}{l}(\mathrm{B}) \\
\text { Salários } \\
(\mathrm{U} \$)\end{array}$ & $\begin{array}{c}\text { (C) } \\
\text { Valor da Transforma- } \\
\text { ção Industrial (U\$) }\end{array}$ & $\begin{array}{l}\text { (D) })^{(1)} \text { M édia } \\
\text { salário/ } \\
\text { ano(B/A) }\end{array}$ & $\begin{array}{l}\text { (E)Riqueza/ } \\
\text { funcionário } \\
\text { (C/A) }\end{array}$ & $\begin{array}{l}\text { (F)M ais- } \\
\text { valia } \\
\text { (absoluto) } \\
\text { (E/D) }\end{array}$ & $\begin{array}{c}(\mathrm{G})^{(2)} \\
\text { Mais-valia } \\
\text { (relativo) } \\
(\mathrm{F} / \mathrm{D}) \\
\end{array}$ \\
\hline $\begin{array}{l}1960 \\
1980\end{array}$ & $\begin{array}{l}615 \\
518\end{array}$ & $\begin{array}{l}6.633 \\
8.157\end{array}$ & $\begin{array}{l}2.028 .841 \\
9.432 .326\end{array}$ & $\begin{array}{r}5.570 .302 \\
49.203 .257\end{array}$ & $\begin{array}{r}305,9 \\
1.156,3\end{array}$ & $\begin{array}{r}839,8 \\
6.032,0\end{array}$ & $\begin{array}{r}533,9 \\
4.875,7\end{array}$ & $\begin{array}{l}1,7 \\
4,2\end{array}$ \\
\hline 2000 & 1.371 & 10.746 & 16.653 .184 & $\ldots$ & $1.549,7$ & $\ldots$ & $\ldots$ & $\ldots$ \\
\hline
\end{tabular}

FONTE: Organizada por Brito (2004), com base em IBGE (1966, 1984, 2002.

(1) Salário médio mensal: U\$26, em 1960, U\$ 96, em 1980 e, U\$129, em 2000. Obtém-se o salário médio mensal dos funcionários dividindo-se os valores da coluna D por 12 (doze meses). (2) Para G =1, a extração da mais-valia relativa é $100 \%$. ... Dado numérico não disponível.

Tabela 24 - RPBA: extração de mais-valia relativa na atividade industrial - 1960, 1980 e 2000

\begin{tabular}{l|c|c|c|c|c|c|c|c}
\hline Período & $\begin{array}{c}\text { Estabele- } \\
\text { cimentos }\end{array}$ & $\begin{array}{c}(\mathrm{A}) \\
\text { Funcio- } \\
\text { nários }\end{array}$ & $\begin{array}{c}(\mathrm{B}) \\
\text { Salários } \\
(\mathrm{U} \$)\end{array}$ & $\begin{array}{c}\text { Valor da Transforma- } \\
\text { ção Industrial (U\$) }\end{array}$ & $\begin{array}{c}(\mathrm{D}) \text { (1)M édia }_{\text {salário/ }} \\
\text { ano(B/A) }\end{array}$ & $\begin{array}{c}\text { (E)Riqueza/ } \\
\text { funcionário } \\
(\mathrm{C} / \mathrm{A})\end{array}$ & $\begin{array}{c}(\mathrm{F}) \mathrm{M} \text { ais- } \\
\text { valia } \\
\text { (absoluto) } \\
(\mathrm{E} / \mathrm{D})\end{array}$ & $\begin{array}{c}(\mathrm{G})(2) \\
\text { Mais-valia } \\
(\text { relativo) } \\
(\mathrm{F} / \mathrm{D})\end{array}$ \\
\hline 1960 & 344 & 4.793 & 2.802 .458 & 15.347 .169 & 584,7 & $3.202,0$ & $2.617,3$ & 4,5 \\
1980 & 612 & 37.594 & 206.504 .071 & 1.907 .211 .475 & $5.493,0$ & $50.731,8$ & $45.238,8$ & 8,2 \\
2000 & 1.608 & 32.903 & 308.036 .075 & $\ldots$ & $9.361,9$ & $\ldots$ & $\ldots$ & $\ldots$ \\
\hline
\end{tabular}

FONTE: Organizada por Brito (2004), com em IBGE (1966, 1984, 2002.

(1) Salário médio mensal: U\$49, em 1960, U\$ 458, em 1980, e U\$780, em 2000. Obtém-se 0 salário médio mensal dos funcionários dividindo-se os valores da coluna $D$ por 12 (doze meses). (2) Para $G=1$, a extração da mais-valia relativa é $100 \%$.... Dado numérico não disponível.

Esse incremento no VTI, produzido pelas indústrias localizadas nessa área, inclusive com uma proporção cada vez menor do número de estabelecimentos industriais que era de $27,5 \%$, em 1960, diminuindo para 15,9\%, em 1980, em relação ao total de estabelecimentos do estado da Bahia, deveu-se, principal- 
mente, à participação das novas indústrias instaladas no CIA e no Copec e às modificações nas instalações industriais da Petrobras.

Certamente, trata-se de indústrias intensivas em capital, contrariamente às demais indústrias localizadas no interior do estado que, pelos dados, presume-se sejam indústrias menos intensivas em capital.

As indústrias localizadas especialmente no $\mathrm{CIA}$ e no Copec e em suas adjacências contribuíram sobremaneira para a elevação da geração de riqueza na economia regional e na ampliação da quantidade de riqueza produzida por operário, a qual se acha representada pelo valor correspondente à taxa de maisvalia dessas indústrias. Esse fato, associado às lutas sindicais no início dos 1980, refletiu-se no aumento dos salários dos operários.

Da massa do VTI produzido pelas indústrias instaladas na RPBA, no Recôncavo "canavieiro/fumageiro" e em Salvador, na década de 1980, 15,8\% correspondeu às indústrias localizadas exclusivamente na capital; $82,1 \%$ foi gerado na RPBA sem a participação da capital e apenas 2,1\% foi gerado nas indústrias localizadas no Recôncavo "canavieiro/fumageiro".

Como resultado do grau de industrialização mais elevado registrado na RPBA, conclue-se que esse subespaço constitui uma unidade com maior grau de "luminosidade" que o Recôncavo "canavieiro/fumageiro".

Essa propriedade da RPBA mantém forte coerência com outros fatores essenciais ligados direta e indiretamente à reprodução do capital, tais como: consumo de energia elétrica não residencial 45,5\%,46,7\% e 7,8\%; número de agências bancárias $68,6 \%, 19,8 \%$ e 11,6\%; e terminais telefônicos em serviço 84,5\%, 12,3\% e 3,2\%, localizados respectivamente em Salvador, na RPBA e no Recôncavo "canavieiro/fumageiro". Porém, é importante frisar que não se verifica qualquer homogeneidade entre os distintos municípios que compõem os correspondentes subespaços.

Essas informações ratificam a assertiva desenvolvida por Marx e Engels (1984), segundo a qual, a intensificação da divisão do trabalho num país ou numa região resulta por aprofundar e tornar mais complexa essa divisão espacial do trabalho, em que algumas partes desempenham funções com elevado grau de destaque funcional, enquanto outras cumprem funções menos relevantes, segundo sua posição na específica divisão espacial do trabalho.

Nessas condições, ao longo de meio século - no Recôncavo "canavieiro/ fumageiro" a divisão espacial do trabalho teve pouca alteração tanto qualitativa como quantitativamente - na RPBA e, sobretudo, na RMS consolidou-se a grande indústria intensiva em capital. Nas demais partes da própria RPBA, tem lugar o desenvolvimento de uma indústria menos homogênea, no tocante à utilização do recurso capital intensivo e ao produto. 
Convém frisar que pouco mais de duas décadas - de 1954 a 1980 - foram suficientes para incorporar a tendência de tornar hegemônico o know-how capitalista de produção de mercadorias, especialmente na RPBA, em sua forma universal e mais avançada, proporcionado pela inserção da Petrobras no Recôncavo Baiano, e pelas articulações de ações entre a corporação e os demais interlocutores interessados em obter ganhos nas atividades econômicas a montante e a jusante da produção de petróleo e gás natural no Recôncavo Baiano.

\section{Implicações sociais e profissionais da inserção da Petrobras no Recôncavo Baiano}

As novas formas de produzir mercadorias na Bahia, com a instalação de indústrias incentivadas pela Sudene se materializaram na produção em série, em larga escala, intensiva em capital e baseada no sistema fordista/taylorista de produção e organização do trabalho. Por sua vez, devido à sua ampla escala de produção e ao seu caráter mais universal e, logicamente, mais avançado processo produtivo, essa nova matriz técnico-econômico-produtiva foi capaz de gerar uma grande massa de operários fabris e técnicos relativamente melhor remunerados, à disposição da nova indústria instalada no estado da Bahia.

$\mathrm{Na}$ esteira das transformações sócio-técnicas e produtivas ocorridas na Bahia, provocadas inicialmente pelas ações da Petrobras, fica patente que a nova indústria também contribuiu para criar regionalmente uma massa relativamente importante de quadros técnico-profissionais superiores - químicos, psicólogos, contadores, advogados, assistentes sociais, administradores, engenheiros etc., vinculados direta e indiretamente a essa indústria, os quais, na maior parte, residem na cidade do Salvador.

Embora se limite apenas ao Copec, Guimarães (1998) apresenta uma medida aproximada da constituição da força de trabalho nas indústrias do Copec, por volta da metade dos anos 1980:

O total de trabalhadores empregados no Complexo Petroquímico de Camaçari (COPEC) em meados de 1980 era de apenas 44.000 pessoas, [...] Dessa mão-deobra, algo em torno de 4.000 era empregada em gerência e supervisão, ou em atividades de nível superior. 23.000 pessoas eram subcontratadas por meio de empreiteiras em serviço de manutenção (9.700), construção (6.300), projetos (2.700) [estes possivelmente de nível superior], limpeza (2.500), e em outras atividades tais como transporte, segurança, alimentação etc. Sobravam, portanto, 17.000 trabalhadores de nível médio ou primário, qualificados ou semiqualificados, empregados por 47 firmas [...] (GUIMARÃES, 1998, p. 152153). 
Da observação de Guimarães (1998), depreende-se que a quantidade de profissionais de nível superior, ligada às indústrias de transformação na RPBA, é bastante significativa, considerando-se a amostra de 6.700 funcionários somente no Copec.

A análise de Guimarães (1998) exclui as demais indústrias localizadas no município de Salvador; em São Francisco do Conde (a refinaria); em Camaçari e Dias d'Avila, (fora da área do Copec) com indústrias químicas, de minerais não-metálicos e siderurgia do cobre; no CIA, (nos municípios de Simões Filho e Candeias) onde estão instaladas grandes indústrias (siderurgia, química, metalmecânica, alimentos etc.); no município de Pojuca, com a siderurgia de ferro-ligas; e demais municípios da RPBA onde estão localizadas outras indústrias de transformação e unidades da Petrobras.

Este cenário revela um grau de transformação substancial na base educacional/profissional e universitária baiana, cujo campo de ação de seus egressos refletia em número e qualidade um novo modelo de geração de riqueza regional, já distanciado de um passado recente, em que grande parte dos profissionais se encaminhava basicamente para fora do estado e/ou para ocupação de cargos técnico-burocráticos da administração pública, enquanto outros se engajavam nas estruturas público-privadas regionais, como quadros dirigentes da antiga sociedade baiana - em especial, médicos, advogados e engenheiros.

A sistemática da organização do trabalho em fluxo contínuo e com elevado grau técnico, introduzido pela Petrobras nas atividades econômico-produtivas baianas, tornou-se uma regra na nova matriz econômico-produtiva, que foi ampliada com a participação do CIA, do Copec e do Complexo do Cobre e mais recentemente com a nova indústria automobilística também em Camaçari, em operação a partir de 2003.

Essa nova matriz, ao longo do tempo, estendeu-se para outras partes do estado da Bahia e foi de fundamental importância à preparação e capacitação da força de trabalho, diretamente pela própria Petrobras, nos seus centros de treinamento e nos próprios locais de trabalho, como também por via indireta, por meio de convênios firmados a partir de fins dos anos 1950, com a Universidade da Bahia, para formar turmas de geólogos, de engenheiros químicos e de engenheiros de petróleo; convênios também foram firmados com a Escola Técnica Federal da Bahia e com demais colégios para formar técnicos de nível médio com qualificação suficiente para trabalhar na nova indústria.

Ao longo do tempo, essa força de trabalho, habituada ao novo regime e sistemática de trabalho, passou a ser maioria nas indústrias química, petroquímica, metal-mecânica e siderúrgica, dentre outras. Se, de um lado a própria dinâmica da nova matriz econômico-produtiva instalada na RPBA foi responsável pela cri- 
ação de uma grande oferta de força de trabalho, com as qualidades necessárias à lógica da organização do trabalho contemporâneo, por outro, também ajudou a desenvolver os mecanismos de defesa econômica e de formação política, com as respectivas organizações sindicais operárias, para se contrapor às organizações patronais; as últimas aninham-se na Federação das Indústrias do Estado da Bahia (Fieb).

A estrutura de classes anterior a 1960, que evoluiu do antigo sistema, fundada em grupos de prestígio, "[...] cujo status é antes atribuído em virtude do nascimento do que adquirido [...]" (AZEVEDO, T., 1959b, p. 109), foi atravessada e substituída, em grande medida, por relações eminentemente contratuais (GUIMARÃES, 1998), a partir do processo de industrialização e seus rebatimentos na política, na economia, na cultura, na educação e no trabalho regionais.

Foi da própria Petrobras e das transformações econômico-sociais ensejadas na Bahia que emergiram os dois mais importantes órgãos de classe das categorias profissionais baianas - o Sindicato dos Petroleiros (Sindipetro), fundado em 1960, e o Sindicato dos Trabalhadores Petroquímicos (Sindiquímica), fundado em 1978. Conforme Guimarães (1998), a origem do Sindiquímica remonta a 1963, com a fundação da Associação dos Trabalhadores do Copeb (Aspetro). O Copeb era composto pelas duas fábricas de fertilizantes da Petrobras, ainda em implantação na época.

Esses dois sindicatos, que a partir de 2000 fundiram-se no Sindiquímica, lideravam a formação política e ideológica de classe dos trabalhadores baianos, identidade reconhecida após a primeira greve dos trabalhadores do Pólo Petroquímico, em 1979, organizada pelo Sindiquímica (GUIMARÃES, 1998).

Essas transformações, que têm desdobramentos complexos, não somente nas dimensões produtivas e do trabalho, mas também na própria organização social e política da vida regional, ocorreram, em grande medida, como resultado da inserção da Petrobras no Recôncavo Baiano e do desenvolvimento de suas práticas espaciais associadas às dos demais agentes presentes no território.

\section{A evolução da rede urbana sub-regional, 1960-2000}

A inserção da Petrobras na RPBA e o desenvolvimento de suas ações com a descoberta e exploração de novos campos de petróleo e gás natural, a implantação da respectiva infraestrutura de apoio junto aos grandes campos de produção de óleo e gás - estradas, alojamentos, fábricas, escritórios etc. -, e o grande sistema industrial e gerencial instalado a jusante das jazidas minerais contribuíram diretamente para a produção de modificações complexas, de ordem estrutural e funcional na rede urbana sub-regional. 
Entre 1950 e 2000, em decorrência do desenvolvimento das atividades petrolíferas na RPBA, muitas cidades aumentaram bastante o seu tamanho demográfico e sua respectiva importância funcional, ao tempo em que surgiram outras com a emancipação de municípios.

Em 1960, além da cidade do Salvador que possuía mais de 600 mil habitantes, existiam onze núcleos urbanos na RPBA que concentrava uma população de 121.424, habitantes num total de 273.075 pessoas, ou seja, $44,5 \%$ da população habitava em áreas urbanas. Esse foi o período em que se iniciou a fase de crescimento urbano mais rápido nessa área. Mesmo assim, somente Alagoinhas possuía população urbana com mais de 40 mil habitantes, dos quais 38.246 residiam na cidade; em nenhum outro município da RPBA, a população urbana atingia 15 mil habitantes, e apenas Candeias tinha mais de 10 mil habitantes residindo na cidade (Tabela 25).

Tabela 25 - RPBA: população residente por situação de domicílio - 1960

\begin{tabular}{l|r|r|r|r}
\hline \multirow{2}{*}{ Municípios } & \multicolumn{4}{|c}{ População } \\
\cline { 2 - 5 } & \multicolumn{1}{|c}{ Total } & Urbana & Na sede & \multicolumn{1}{c}{ Rural } \\
\hline Salvador & 630.078 & 612.166 & 607.713 & 18.712 \\
Alagoinhas & 75.422 & 42.571 & 38.246 & 32.851 \\
São Sebastião do Passé & 23.963 & 8.300 & 4.104 & 15.663 \\
Mata de São João & 23.393 & 10.921 & 8.117 & 12.472 \\
Camaçari & 21.849 & 10.031 & 5.342 & 11.818 \\
Entre Rios & 21.772 & 3.092 & 1.185 & 18.680 \\
Catu & 21.721 & 9.686 & 8.883 & 12.035 \\
Itaparica & 25.276 & 11.629 & 4.308 & 13.647 \\
Candeias & 18.484 & 12.500 & 12.500 & 5.984 \\
São Francisco do Conde & 18.455 & 3.930 & 3.005 & 14.525 \\
Esplanada & 14.165 & 4.547 & 3.792 & 9.618 \\
Pojuca & 8.575 & 4.217 & 4.054 & 4.358 \\
Total & 903.153 & 733.590 & 701.249 & 170.363 \\
\hline
\end{tabular}

FONTE: Organizada por Brito (2004), com base em IBGE (1961).

Já na área "canavieira/fumageira", com quinze municípios, a população total era de 428.023 habitantes, 1,6 vezes maior que a população da RPBA, exclusive a capital. A população residente em áreas urbanas, 168.800 habitantes, era 1,4 vezes maior que a da RPBA, mas em termos relativos atingia apenas $39,4 \%$. Nessa parte, o município de Santo Amaro destacava-se com população urbana superior a 45 mil habitantes, entre os quais 17,226 (37\%) residiam na sede do município; em seis outros municípios, a população, que vive em aglomerados urbanos, distribuía-se em grupos entre 10 mil e 20 mil habitantes, entre esses municípios havia cinco cidades com população entre 10 e 15 mil habitantes; nos oito municípios restantes a população urbana não atingia 10 mil habitantes (Tabela 26). 
Tabela 26 - Recôncavo "canavieiro/fumageiro": população residente por situação de domicílio - 1960

\begin{tabular}{|c|c|c|c|c|}
\hline \multirow{2}{*}{ Municípios } & \multicolumn{4}{|c|}{ População } \\
\hline & Total & Urbana & Na sede & Rural \\
\hline Santo Amaro & 100.221 & 46.563 & 17.226 & 53.658 \\
\hline Maragogipe & 39.742 & 19.322 & 12.575 & 20.420 \\
\hline Muritiba & 38.046 & 13.589 & 9.679 & 24.457 \\
\hline São Gonçalo dos Campos & 33.434 & 7.343 & 5.391 & 26.091 \\
\hline Cachoeira & 28.869 & 13.916 & 11.415 & 14.953 \\
\hline Nazaré & 28.258 & 15.977 & 14.644 & 12.281 \\
\hline Santo Antônio de Jesus & 27.945 & 14.902 & 14.902 & 13.043 \\
\hline São Felipe & 24.681 & 2.336 & 1.579 & 22.345 \\
\hline Conceição do Almeida & 24.368 & 4.566 & 3.942 & 19.802 \\
\hline Cruz das Almas & 24.196 & 12.190 & 12.190 & 12.006 \\
\hline São Félix & 14.866 & 6.059 & 5.993 & 8.807 \\
\hline Sapeaçu & 13.163 & 2.924 & 2.108 & 10.239 \\
\hline Jaquaripe & 11.858 & 3.410 & 941 & 8.448 \\
\hline Conceição da Feira & 11.418 & 3.057 & 3.057 & 8.361 \\
\hline Aratuípe & 6.958 & 2.646 & 1.508 & 4.312 \\
\hline Total & 428.023 & 168.800 & 117.150 & 259.223 \\
\hline
\end{tabular}

FONTE: Organizada por Brito (2004), com base em IBGE (1961).

Em termos médios, nos anos 1960, o grau de urbanização da população nas duas partes ainda era baixo, inferior a 50\%. Na RPBA, havia municípios onde a taxa de urbanização mais alta era de $68 \%$ (Candeias) e a mais baixa 14\% (Entre Rios); na área "canavieira/fumageira", a mais alta era 56\% (Nazaré) e a mais baixa 9\% (São Felipe). Mesmo assim, a urbanização da população já apresentava tendências de crescimento (Figura 6). Esse crescimento urbano ocorria basicamente como resultado de fatores de estagnação econômica em ambas as partes da região (SINGER, 1981).

No Recôncavo "canavieiro/fumageiro", o processo de emigração da população das áreas rurais descrito por Santos, M. (1959a), já evidente nos anos 1950, prolongou-se nas duas décadas seguintes, quando se deu o colapso da economia açucareira e fumageira, com a liquidação da quase totalidade das usinas de açúcar e das fábricas de fumo. Com isso, parte significativa da população da zona da cana e do fumo transferiu-se para as áreas adjacentes (petrolíferas) que poderiam oferecer algum tipo de expectativa de progresso social para essa população migrante - a cidade de Salvador e a RPBA - em busca do possivel emprego urbano e nas atividades da extração e industrialização do petróleo e do gás natural.

Entretanto, a cidade do Salvador, também imersa no ambiente de letargia econômica, presente em todas as partes do estado da Bahia, não atendia às expectativas dos milhares de novos habitantes que se instalavam na cidade a cada ano e sobreviviam como podiam. 
FIGURA 6 - Recôncavo "canavieiro/ fumageiro" e RPBA: distribuição da população total, urbana e rural, por municípios - 1960

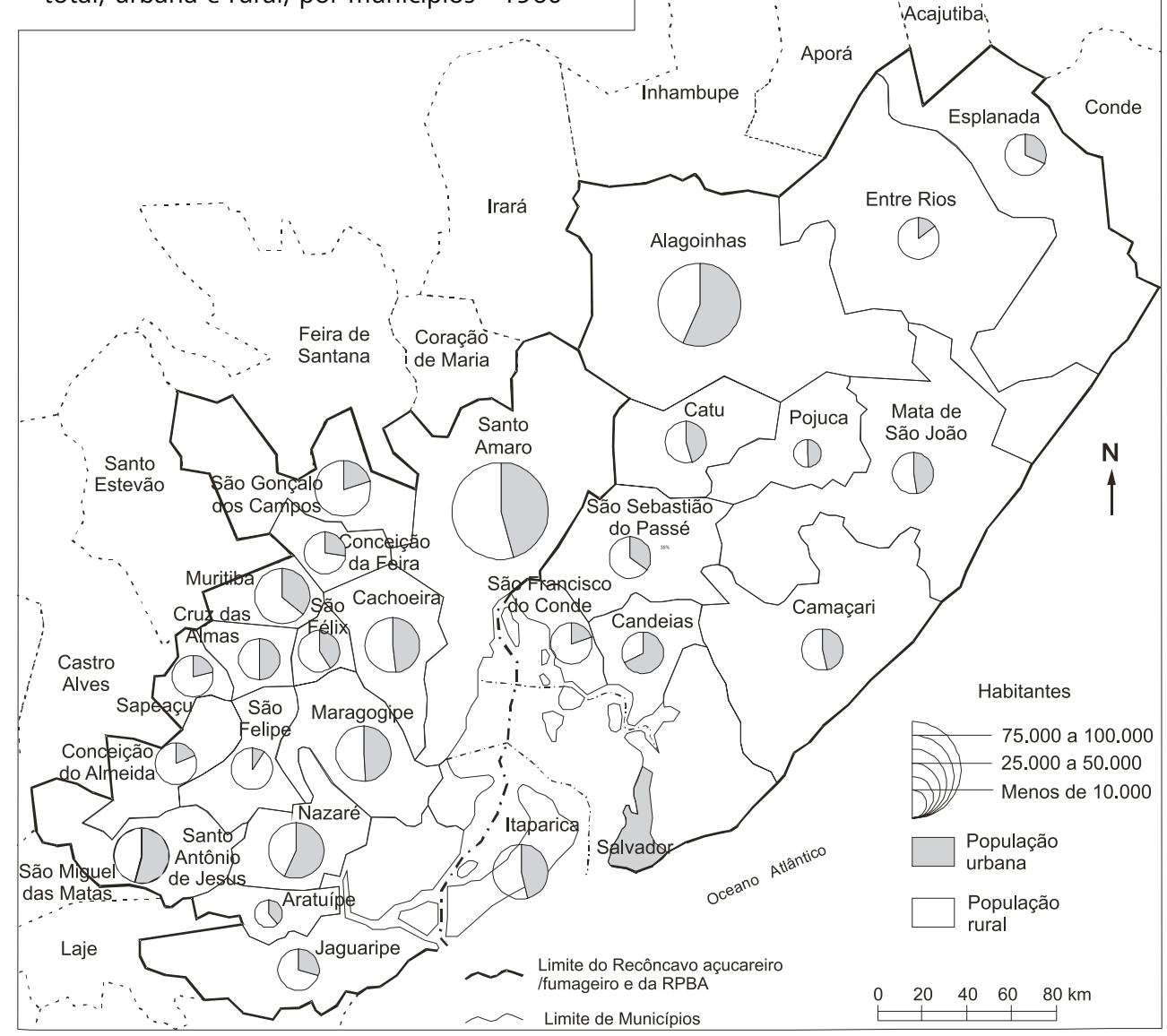

FONTE: Organizada por Brito (2004), com base em IBGE (1961).

Para os grupos de indivíduos que se dirigiam à RPBA e para os naturais das localidades ali existentes, mas que migravam das áreas rurais para as áreas urbanas, as possibilidades de obtenção de melhor êxito pessoal ficavam condicionadas ao desenvolvimento das atividades petrolíferas. A população, em grande parte, possuidora apenas da força de trabalho e sem a qualificação necessária para os trabalhos industriais, buscavam colocação profissional diretamente na Petrobras e/ou nas empresas que prestavam serviços a essa corporação.

Convém ressaltar que as atividades de prospecção, extração, transporte e industrialização do óleo foram bastante intensificadas durante a década de 1960, e que, portanto, demandava uma numerosa força de trabalho.

Ao longo dos anos 1960, a estagnação econômica também estava presente na RPBA, porém de intensidade menos aguda, em decorrência dos investimentos 
da Petrobras. Deve-se observar, entretanto, que em 1956 o Governo federal baixou decreto declarando desapropriadas todas as terras da área petrolífera em favor da Petrobras. Isso praticamente imobilizou por cinco anos a exploração econômica das terras nessa região.

Nesse sentido, aliada à situação de uma espécie de recesso econômico, verificou-se uma reestruturação agrária e fundiária, provocada pelo avanço da Petrobras nas terras onde se conformaria a RPBA. Esse fato é revelado pelo relatório de pesquisa do Conselho de Desenvolvimento do Recôncavo (Conder), ao tratar da estrutura agrária no Recôncavo Baiano, no fim dos anos 1960:

[...] a instalação de atividades petrolíferas em vários municípios da região veio desorganizar a produção agropecuária ai existente. As desapropriações de terra diminuíram o volume antes destinado à agricultura, e a oferta, direta ou indireta de empregos, fez com que muitos pequenos agricultores, justamente os responsáveis pela cultura de subsistência, abandonassem a atividade agrícola para ingressar na própria PETROBRAS ou na estrutura de serviços nascida em função dela. Como isso aconteceu em maior grau com os trabalhadores mais jovens, as famílias se viram desfalcadas de braços para a lavoura e, não podendo explorar toda a sua terra à base de mão-deobra composta de velhos e crianças, preferiram vender parte dessa terra, aumentando, assim o número de pequenas propriedades (BAHIA, [1972?], p. 19).

Na trajetória do processo de expulsão de parte da população das áreas rurais para as áreas urbanas na RPBA, também tiveram importância crucial as ações da Ferbasa e de sua empresa controlada, a Reflora. A Ferbasa é uma empresa do setor de siderurgia de ferro-ligas, instalada em 1961, no município de Pojuca e, além das matérias-primas minerais e outros insumos, também utiliza madeira em seus processos industriais. Para prover suas demandas por madeira, a holding constituiu a empresa Reflora, que opera no seguimento de madeira e agropecuária.

A partir da década de 1960, a Reflora passou a adquirir grande quantidade de terras ao longo da rodovia BA-093 - estrada que a partir do km 14, na BR-324, na direção NE, atravessa os municípios da RPBA até atingir a BR-101, em Entre Rios -, em vários municípios, para desenvolver a silvicultura.

Um outro fator que também provocou a migração de uma parcela considerável da população das áreas rurais para os povoados, vilas e cidades foi a reativação da agropecuária extensiva e semi-intensiva nos municípios do Litoral Norte, onde a RPBA se encontra encaixada.

O desenvolvimento dessas atividades, ao lado da difusão do próprio processo de urbanização como modo de vida, e a implantação de estradas que recortou amplas áreas nos municípios da RPBA, suscitaram o crescimento das cidades e vilas, desde os anos 1960.

Movimento semelhante, mas com processos específicos de reorganização das atividades agrárias e comerciais na área do Recôncavo "canavieiro/fumageiro", também provocou o crescimento urbano nesse subespaço, no mesmo período. 
Todos os fatores e processos anteriormente referidos, associados a um movimento demográfico mais macro (imigração, que inclui várias escalas espaciais, e o incremento por crescimento vegetativo) observado em todo o estado da Bahia, contribuíram para que em 2000 a cidade do Salvador alcançasse cerca de 2,5 milhões de habitantes. Em menor proporção, os demais municípios populosos da RPBA experimentaram o mesmo fenômeno, totalizando 944.171 habitantes, registrando um aumento de 3,5 vezes em relação ao número de habitantes existente em 1960.

Sem contar com a capital, a população urbana recenseada na RPBA em 2000 era composta de 807.012 indivíduos, ou seja, $85,7 \%$ da população total. O acréscimo do contingente urbano no período foi de 6,7 vezes, enquanto a população rural diminuiu 24,4\%, passando de 178.761 pessoas, em 1960, para 135.159 pessoas, em 2000.

Dos municípios que compõem a RPBA, sem contar com Salvador, destacam-se três: Camaçari, Alagoinhas e Lauro de Freitas, cuja população residente em áreas urbanas ultrapassa 100 mil pessoas. Há também três municípios com população urbana inferior a 10 mil habitantes: Araças, Cardeal da Silva e Itanagra (Tabela 27). Os demais municípios estão distribuídos em classes intermediárias entre 10 e 100 mil pessoas residentes em aglomerados urbanos - cidades, vilas e povoados.

Para o período de 2000, no subespaço que compõe o Recôncavo "canavieiro/ fumageiro", já com 25 municípios, a população total aumentou 1,4 vezes, passando de 428.023 em 1960, para 581.360 em 2000, e a quantidade de indivíduos que residem em áreas urbanas ampliou-se em 2,3 vezes no mesmo período.

Tabela 27 - RPBA: população residente por situação de domicílio - 2000

\begin{tabular}{l|r|r|r}
\hline \multirow{2}{*}{ Municípios } & \multicolumn{3}{|c}{ População } \\
\cline { 2 - 4 } & \multicolumn{1}{|c|}{ Total } & Urbana & \multicolumn{1}{c}{ Rural } \\
\hline Salvador & 2.443 .107 & 2.442 .102 & 1.005 \\
Camaçari & 161.727 & 154.402 & 7.325 \\
Alagoinhas & 130.095 & 112.440 & 17.655 \\
Lauro de Freitas & 113.543 & 108.385 & 5.158 \\
Simões Filho & 94.066 & 76.905 & 17.161 \\
Candeias & 76.783 & 69.127 & 7.656 \\
Dias d'Ávila & 45.333 & 42.673 & 2.660 \\
Catu & 46.731 & 37.816 & 8.915 \\
São Sebastião do Passé & 39.960 & 29.549 & 10.411 \\
Vera Cruz & 29.750 & 27.872 & 1.878 \\
Mata de São João & 32.568 & 24.969 & 7.599 \\
Entre Rios & 37.513 & 23.019 & 14.494 \\
Pojuca & 26.203 & 21.884 & 4.319 \\
São Francisco do Conde & 26.282 & 21.870 & - \\
Itaparica & 18.945 & 18.945 & 9.692 \\
Esplanada & 27.230 & 17.538 & 437 \\
Madre de Deus & 12.036 & 11.599 & 5.673 \\
Araças & 11.003 & 5.330 & 5.203 \\
Cardeal da Silva & 8.033 & 2.830 & 4.511 \\
Itanagra & 6.370 & 1.859 & 135.159 \\
Total & 944.171 & 809.012 & \\
\hline
\end{tabular}

FONTE: Organizada por Brito (2004), com base em IBGE (2001).

- Dado igual a zero, não resultante de arredondamento. 
Tabela 28 - Recôncavo "canavieiro/fumageiro" população residente por situação de domicílio - 2000

\begin{tabular}{|c|c|c|c|}
\hline \multirow{2}{*}{ Municípios } & \multicolumn{3}{|c|}{ População } \\
\hline & Total & Urbana & Rural \\
\hline Santo Antônio de Jesus & 77.368 & 66.245 & 11.123 \\
\hline Santo Amaro & 58.414 & 44.505 & 13.909 \\
\hline Cruz das Almas & 53.049 & 39.604 & 13.445 \\
\hline Maragogipe & 40.314 & 21.043 & 19.271 \\
\hline Muritiba & 30.644 & 17.905 & 12.739 \\
\hline Cachoeira & 30.416 & 15.831 & 14.585 \\
\hline São Gonçalo dos Campos & 27.000 & 13.552 & 13.448 \\
\hline Nazaré & 26.365 & 23.011 & 3.354 \\
\hline Conceição do Jacuípe & 26.194 & 19.466 & 6.728 \\
\hline Amélia Rodrigues & 24.134 & 19.022 & 5.112 \\
\hline São Felipe & 20.228 & 8.250 & 11.978 \\
\hline Conceição do Almeida & 18.912 & 8.318 & 10.594 \\
\hline Conceição da Feira & 17.514 & 11.237 & 6.277 \\
\hline Governador Mangabeira & 17.165 & 6.684 & 10.481 \\
\hline Sapeaçu & 16.450 & 7.524 & 8.926 \\
\hline São Félix & 13.699 & 8.748 & 4.951 \\
\hline Jaguaripe & 13.422 & 4.632 & 8.790 \\
\hline Terra Nova & 12.875 & 11.131 & 1.744 \\
\hline Salinas da Margarida & 10.377 & 4.611 & 5.766 \\
\hline Saubara & 10.193 & 10.076 & 117 \\
\hline Teodoro Sampaio & 8.884 & 6.627 & 2.257 \\
\hline Varzedo & 8.673 & 2.627 & 6.046 \\
\hline Aratuípe & 8.381 & 4.787 & 3.594 \\
\hline Muniz Ferreira & 6.941 & 3.301 & 3.640 \\
\hline Dom Macedo Costa & 3.748 & 1.297 & 2.451 \\
\hline TOTAL & 581.360 & 380.034 & 201.326 \\
\hline
\end{tabular}

FONTE: Organizada por Brito (2004), com base em IBGE (2001).

Nessa parte do Recôncavo Baiano, a cidade de Santo Antônio de Jesus é o maior e mais importante núcleo urbano, cuja dinâmica advém da sua localização às margens da rodovia BR-101, que é interceptada pela rodovia BA-001 ligação Santo Antônio de Jesus/Bom Despacho, na llha de Itaparica -, e da consolidação de uma praça comercial importante que distribui bens e serviços para a região em seu entorno; os núcleos de Santo Amaro e Cruz das Almas aparecem em seguida, com população em torno de 40 mil habitantes, e há cerca de metade dos municípios cuja população urbana não atinge a 10 mil pessoas (Tabela 28).

Os dados referentes à população em ambas as áreas indicam que a dinâmica de incremento demográfico foi mais intensa na RPBA que no Recôncavo "canavieiro/fumageiro", apesar de em dois municípios, Cardeal da Silva e Itanagra, as taxas de urbanização serem de $35 \%$ e $29 \%$ respectivamente; são municípios emancipados em 1961, cuja economia baseia-se na pecuária bovina e os respectivos núcleos urbanos desenvolvem baixa interação espacial com os núcleos adjacentes, sobretudo o último. 
Na RPBA, os municípios mais populosos e que possuem maior quantidade de habitantes em áreas urbanas estão concentrados na zona de industrialização densa, na RMS como destaca a Figura 7.

FIGURA 7 - Recôncavo "canavieiro/fumageiro" e RPBA: distribuição da população total, urbana e rural, por municípios - 2000

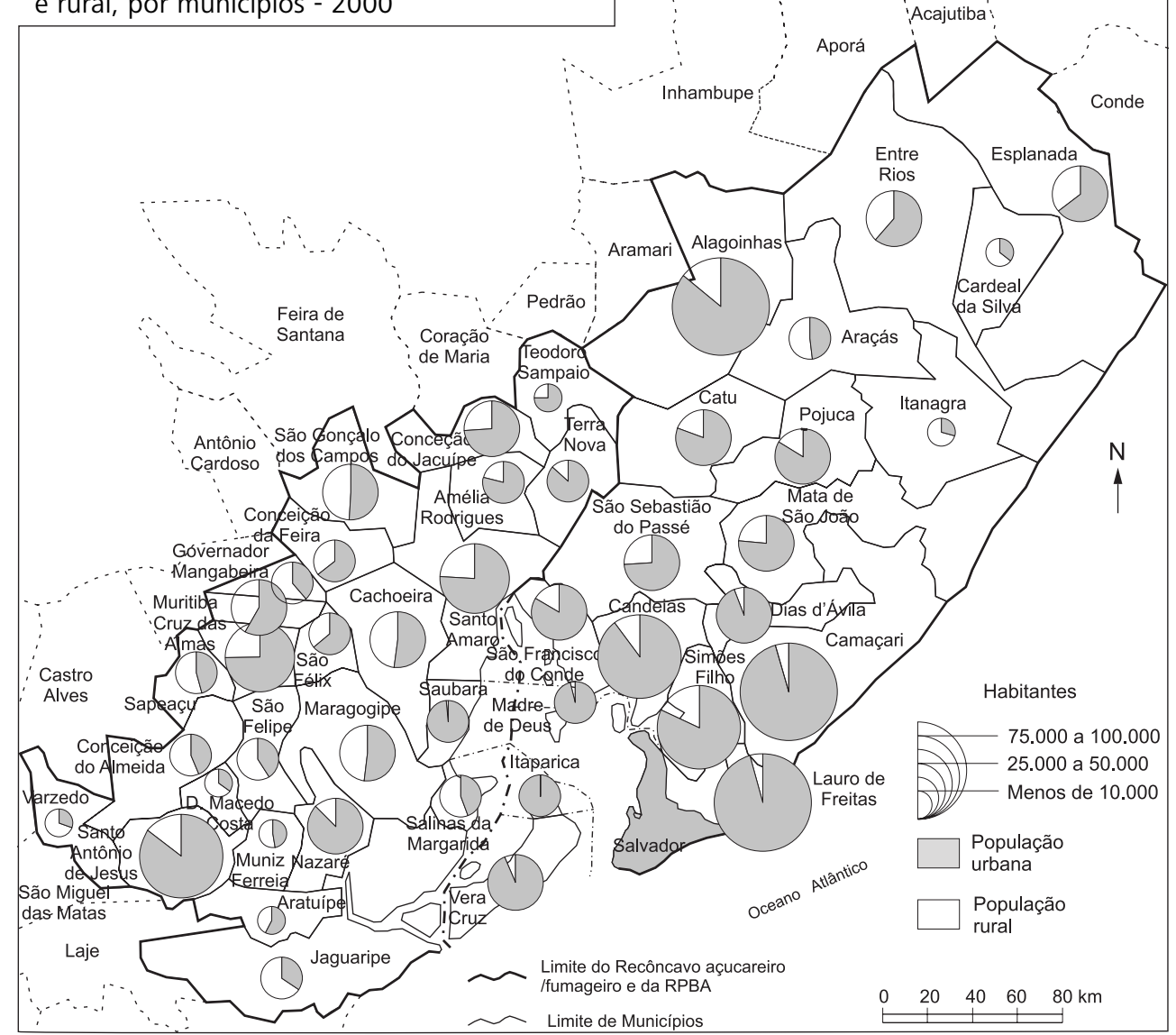

FONTE: Organizada por Brito (2004), com base em IBGE (2001).

\section{A funcionalidade da rede urbana regional no período atual}

Como foi visto, no ano de 1990 se consolidou no Recôncavo "canavieiro/ fumageiro" e na RPBA a estrutura de núcleos urbanos atual que serve de apoio ao atendimento das demandas dos habitantes, das firmas e do Governo presen- 
tes nos respectivos municípios. A configuração espacial resultante foi determinada historicamente pelas dinâmicas dos ciclos de reprodução do capital e da divisão espacial da produção que induziram o surgimento das interações espaciais criadas e desenvolvidas pelos distintos agentes e seus interesses específicos, localizados interna e externamente na região.

Sobrejacente a isso, alguns núcleos urbanos foram sendo servidos de redes geográficas por onde circulam fluxos materiais (caminhos, estradas de rodagem, estradas de ferro, rotas fluviais) e imateriais (rede telefônica, rede de fibra ótica, rede de transmissão de energia elétrica etc.) que, por suas características, têm papel relevante na expansão dos núcleos urbanos. Essas redes constituem o sistema de referências geográficas criado e/ou melhorado e distribuído seletivamente no território, para conectar entre si as demandas dos agentes instalados em diferentes localidades, da própria rede urbana em alusão e também em núcleos urbanos situados alhures.

Tendo-se por base o referido sistema de referências segundo os distintos graus de densidade técnica, maior rapidez e tipos diferentes de aplicação (DIAS, L., 1995a), o tamanho demográfico dos núcleos urbanos, o papel que cada um exerce na divisão espacial da produção e as funções urbanas centrais (atividades de serviços privados e públicos e atividades comerciais) existentes em cada núcleo urbano, elaborou-se um mapa da hierarquia funcional urbana correspondente da região em análise (Figura 8). ${ }^{5}$ Dessa rede urbana, emerge uma nova hierarquia funcional substancialmente mais complexa e com maior grau de interação entre os núcleos que a existente em 1950.

A distribuição espacial dos núcleos urbanos no subsistema regional em estudo guarda certas semelhanças com o modelo teórico das localidades centrais elaborado por Walter Christaller conforme descreve Silva, S. (1975). A rede urbana apresenta poucos núcleos urbanos de elevada hierarquia em torno dos quais aparecem núcleos urbanos de hierarquia inferior. À medida que a hierarquia dos centros diminui, o número de centros aumenta. Essa configuração espacial é resultado das dinâmicas do processo de reprodução do capitalismo e das formas de inserção da região na economia baiana e nacional ao longo de meio século.

As transformações sociais, políticas, econômicas e infraestruturais, ocorridas no estado da Bahia, a partir da inserção da Petrobras no Recôncavo Baiano e dos desdobramentos de suas articulações com os distintos agentes regionais, contribuíram sobremaneira para a descentralização funcional e econômica na Bahia.

\footnotetext{
${ }^{5}$ Em todas as cidades da região em estudo pesquisou-se, na lista telefônica impressa e no CD-Rom, 138 funções urbanas centrais consideradas mais relevantes segundo graus diferentes de complexidade, como sugerem Silva, S.; Souza, J. (1991), Duarte (1974) e IBGE (1993). Os procedimentos de classificação hierárquica aplicados foram os mesmos utilizados para a hierarquização em 1950.
} 
Disso resultou o surgimento de núcleos urbanos que, pela natureza da base econômica municipal (seja industrial, comercial/serviços e/ou agropecuária/extrativa), desenvolvem interações espaciais mais ou menos intensas com vários outros centros próximos e distantes, além de Salvador, que na condição de metrópole regional, ocupa a primeira posição.

FIGURA 8 - Recôncavo "canavieiro/fumageiro" e RPBA: organização funcional urbana - 2000

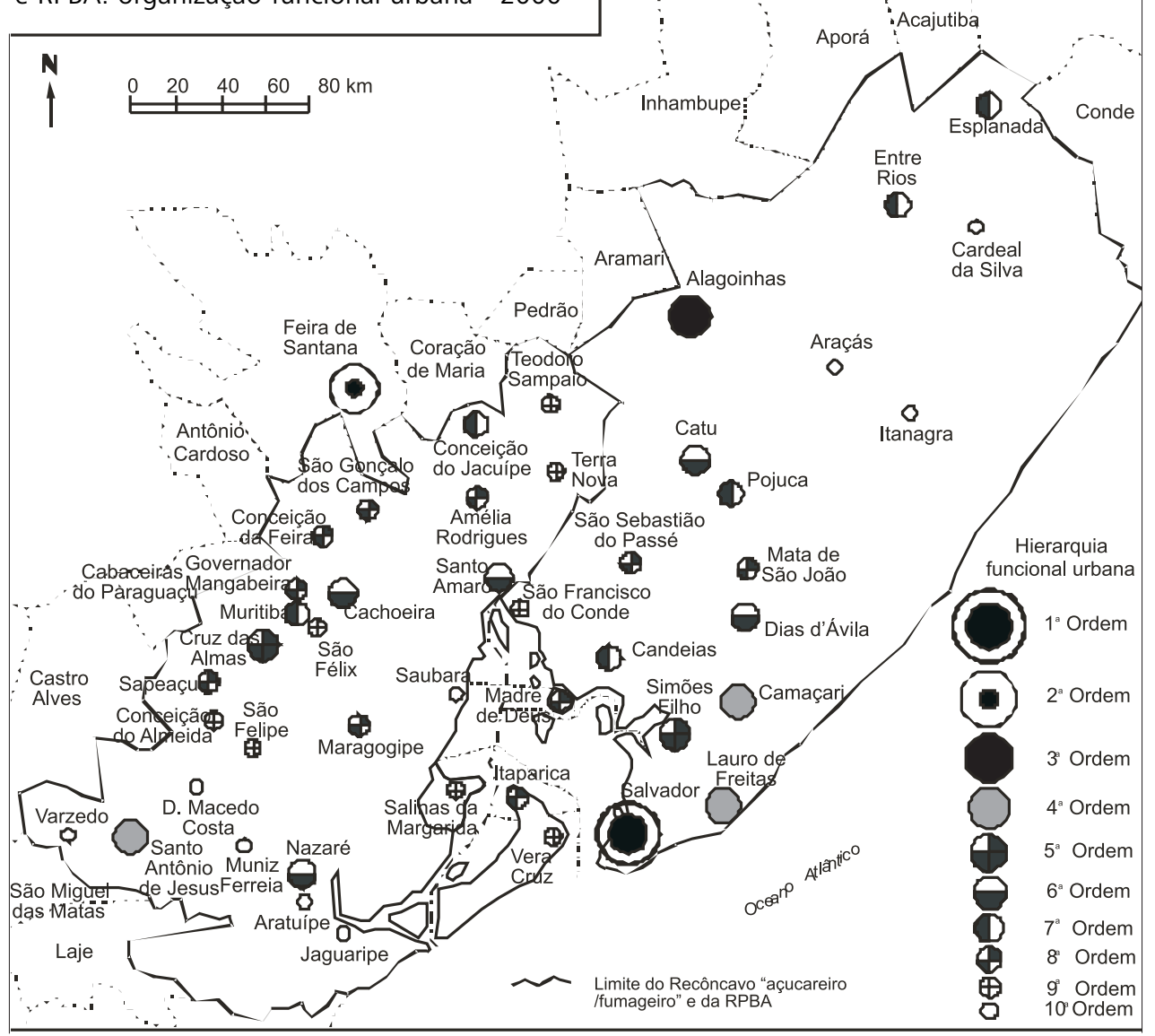

FONTE: Organizada por Brito (2004), com base em Telemar (2000) e Editel (2000).

Nessa rede urbana, a cidade de Feira de Santana exerce papel funcional de destaque, logo abaixo de Salvador, fornecendo uma gama variada de bens e serviços para uma hinterland bem extensa. Alagoinhas é para o Litoral Norte a cidade de maior importância, depois de Salvador. Na classificação funcional, essa cidade assume a terceira posição. Nesse subsistema urbano algumas das mais importantes cidades localizam-se na antiga zona "açucareira/fumageira" - Santo 
Antônio de Jesus ( $4^{\mathrm{a}}$ ordem) e Cruz das Almas ( $5^{\mathrm{a}}$ ordem); e outras, Lauro de Freitas e Camaçari (ambas de $4^{\text {a }}$ ordem), localizam-se na RMS.

Os núcleos urbanos que desempenhavam papel importante como entreposto comercial fumageiro e açucareiro nos anos 1950, classificados então como centros de segunda ordem, logo depois da cidade do Salvador, a exemplo de Santo Amaro, Cachoeira e Nazaré, atualmente somente aparecem a partir da sexta ordem, como resultado da estagnação econômica que se verifica com maior intensidade na parte do Recôncavo "canavieiro/fumageiro".

Esse fato quer dizer que a importância demográfica, funcional, econômica etc. de uma cidade não guarda nenhuma relação com uma evolução linear, mas sim com os processos sociais que se desenvolvem ao longo do tempo, que resulta em maior ou menor interação espacial entre dados núcleos urbanos de uma rede de cidades.

A estagnação econômica predominante no Recôncavo "canavieiro/fumageiro" reflete-se também na ocorrência de grande quantidade de núcleos urbanos de natureza funcional mais elementar.

A interpretação da configuração territorial da rede urbana deve ser feita associada a pelo menos dois elementos essenciais: o arcabouço rodoviário subjacente, que articula econômica e funcionalmente os distintos núcleos urbanos interna e externamente por meio de fluxos de natureza material - transporte de pessoas e objetos reais, como mostra a Figura 9, e, dentre outros sistemas de comunicação remota, as redes de terminais de telefones, de fibra ótica e terminais de microcomputadores, instalados nas empresas, prefeituras, escolas e nas residências, que combinadas potencializam os limites máximos de eficiência e velocidade na transmissão de dados - texto, imagem e voz via intranet e internet.

A impossibilidade de dispor dos dados sobre o volume de ligações telefônicas e dos acessos a provedores de internet que tiveram origem e que foram atendidos nas distintas localidades, para efeito de mensuração aqui, implicou a utilização da quantidade de microcomputadores por cada um mil domicílios localizados nas cidades para indicar a dimensão técnica e informacional associada aos núcleos urbanos como mostra a Figura 10.

O mapa destaca a localização da quantidade de microcomputadores instalados nos domicílios (os dados referentes às empresas não foram divulgados pelo IBGE). Considera-se que todas as prefeituras, agências bancárias, agências de correios, casas lotéricas, empresas de grande e médio porte e algumas de pequeno porte localizadas nas respectivas cidades dispõem desse equipamento e, ain$\mathrm{da}$, que no período atual os equipamentos instalados em residências, bem como os não residenciais, despôem de interface de acesso discado ou não à internet e/ ou à intranet. 
FIGURA 9 - Recôncavo "canavieiro/fumageiro" e RPBA: sistema rodo-ferroviário de transporte - 2000

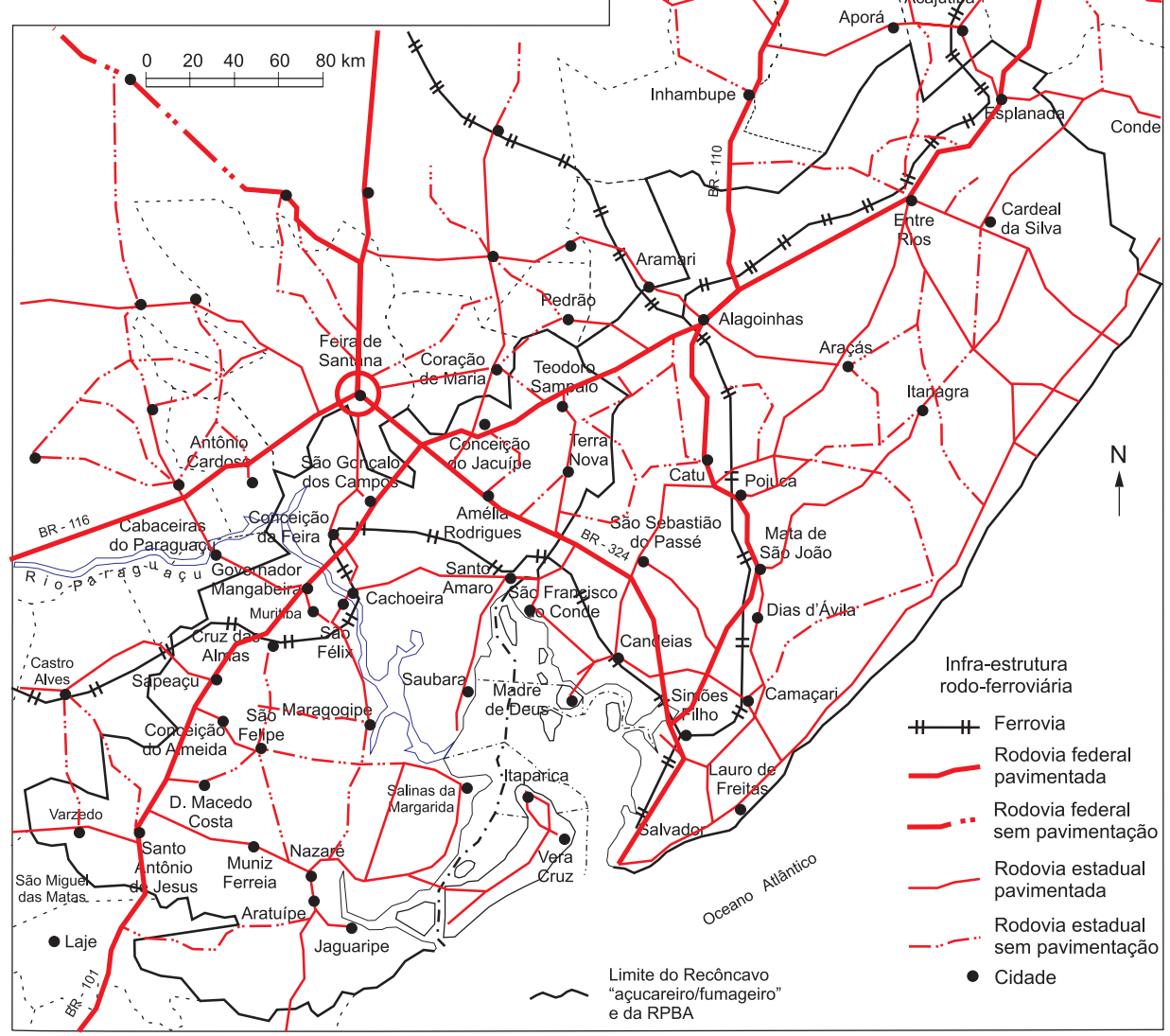

FONTE: Organizada por Brito, com base em Bahia (2001b).

As redes, sobretudo as de acesso por terminais de computador, permitem aos seus usuários não somente a transmissão e recebimento de fluxos de informações em volumes cada vez maiores e mais diversificados, mas também a instantaneidade, a alta velocidade das transmissões das informações e a eliminação das distâncias, sem, contudo, anular o espaço geográfico. A esse respeito escreve Dias, L. ${ }^{6}$ :

La diffusion des micro-ordinateurs et la mise em place par I'EMBRATEL du réseau TRANSDATA em 1981 permet aux organizations de prendre pied dans le domaine

\footnotetext{
${ }^{6}$ A difusão dos microcomputadores e a instalação pela EMBRATEL da rede TRANSDATA em 1981 permite às organizações tomar pé no domínio que ainda lhes escapava - aquele da comunicação instantânea com os parceiros extramuros das fábricas ou das sedes das empresas; em outros termos a proximidade geográfica não é mais a condição preliminar para a transmissão instantânea de informações (1995b, p. 123)
} 


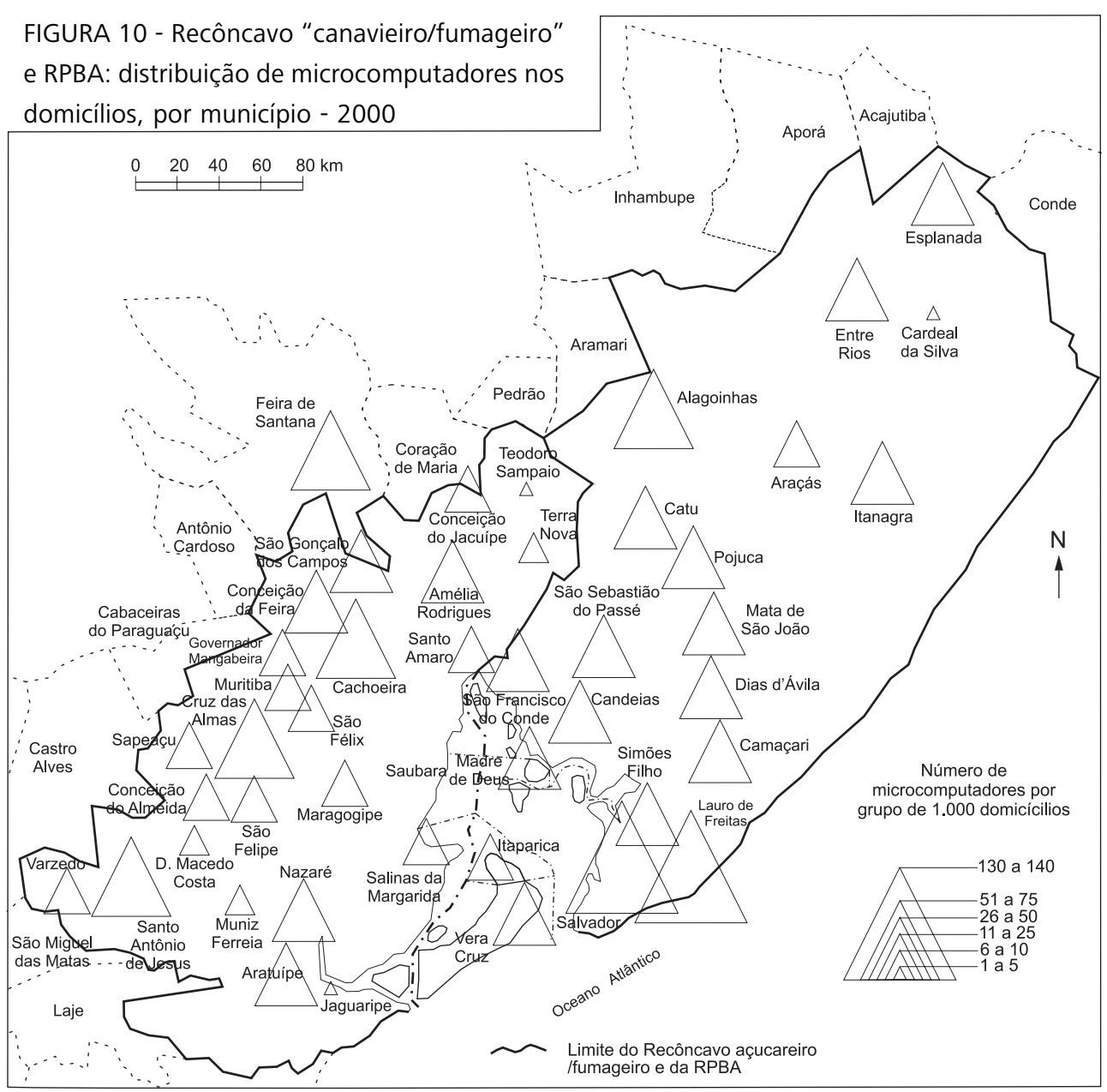

FONTE: Organizada por Brito (2004), com base em IBGE (2000).

qui leur échappe encore - celui de la communicacation instantanée avec des partenaires extra-muros de l'usine ou du siège; em d'autres termes la proximité géographique n'est plus la condition préalable à la transmission instantanée d'information (DIAS, L., 1995b, p. 123).

Esse fato constitui a característica principal da combinação entre a informática e as redes de telecomunicações, tornando fluido o espaço geográfico por meio da aceleração dos ritmos das interações espaciais, sem, contudo, o anular. Essas novas técnicas garantem a agilidade das ações dos agentes que dispõem das condições materiais e que possuem interesses localizados em partes distintas do espaço geográfico. 
Evidentemente, o acesso a essa rede se dá segundo princípios de seletividade econômica e funcional de custo financeiro elevado, desproporcional à capacidade de consumo da maior parte das famílias e das pequenas firmas brasileiras. Mas é exatamente isso que contribui para reforçar e materializar as desigualdades na hierarquia funcional dos núcleos urbanos nas economias capitalistas, refletindo o papel na divisão espacial da produção e a correspondente distribuição desigual da riqueza econômica, do número de habitantes e do acesso a bens e serviços localizados nos distintos núcleos urbanos.

A rarefação da densidade de microcomputadores em algumas cidades indica uma menor abertura e pouca interação espacial com outras cidades, o que implica o baixo nível hierárquico, a reduzida capacidade de realização econômica da população local e o acentuado nível de pobreza dessa população que, por isso, tem sua capacidade de demanda por bens e serviços muito limitada.

A rede urbana em foco é liderada pela cidade do Salvador, que desempenha a função de metrópole regional, agora não mais como uma caricatura de macrocefalia, que drena para si a maior parte dos recursos econômicos e sociais da região, como era caracterizada até os anos 1960. Essa rede urbana ganhou complexidade e encontra-se inserida, pelo menos em parte, no ritmo contemporâneo de aceleração do tempo, imposto pelas demandas dos agentes hegemônicos: bancos, grandes e médias empresas industriais, comercias e de prestação de serviços que operam em rede e acham-se localizados em vários núcleos urbanos.

Para ilustrar essa aceleração do tempo no território em foco, tem-se, fora da RMS, além das próprias unidades da Petrobras e outras grandes companhias, o exemplo da fábrica da cervejaria Schincariol, instalada no município de Alagoinhas, em fins dos anos 1990. Diante do grau elevadíssimo de concorrência nesse setor, a empresa necessita de um sistema de comunicação instantânea com todas as suas unidades de negócios, as quais se encontram distribuídas em várias partes do Brasil.

Um outro exemplo é a Ferbasa, que opera na siderurgia de aços especiais e foi, na escala nacional, a segunda mais importante empresa do subsetor, em 2000 (ESPECIAL..., 2000). Esta empresa tem sua fábrica localizada no município de Pojuca e as matérias-primas são extraídas de minas localizadas em municípios baianos, relativamente distantes - Campo Formoso, Andorinha, Jacobina e outros. Já a madeira utilizada nos processos industriais é extraída de áreas mais próximas, nos próprios municípios da RPBA - Entre Rios, Esplanada, Pojuca, dentre outros.

A Ferbasa constitui-se numa holding que possui treze empresas controladas, que operam nos setores de mineração, reflorestamento e agropecuária, e tem participação (entre $64 \%$ e $100 \%$ do capital) em mais quatorze companhias. Logo, o núcleo gerencial desta empresa também necessita realizar comunicações velo- 
zes e eficientes com todas as demais unidades de negócios, que se encontram distribuídas em distintas partes do estado da Bahia e com seus clientes e fornecedores em regiões alhures.

Associada às redes de comunicação remota, têm-se as redes materiais de transporte rodoviário, de cargas e de passageiros, que integram espacialmente os núcleos urbanos próximos e distantes.

Os fluxos de transporte rodoviário de passageiros permite mapear na rede urbana em estudo, nós, ou seja, núcleos urbanos, que devido a quantidade de fluxos rodoviários que lhes chega e/ou tem origem, permite vinculá-los à respectiva posição na hierarquia funcional dos centros na rede urbana. Por meio dessa cartografia, pode-se verificar a relevância geográfica e funcional das cidades na rede urbana.

A onipresença da cidade do Salvador na região e, por extensão, em todo o estado da Bahia, é flagrante. A capital atinge as cidades de Alagoinhas, Entre Rios, São Félix e Santo Antônio de Jesus com um fluxo diário de até dez linhas de ônibus em cada trajeto de ida e volta, conforme evidencia a Figura 11.

Essa presença ostensiva da cidade do Salvador nas demais localidades do estado da Bahia ocorre pela condição de oferecimento de uma gama ampla e variada de bens e serviços de natureza simples e também complexa (IBGE, 2000; SILVA, S.; SOUZA, J., 1991) à população externa em oposição à escassez de oferta desses bens e serviços nas outras localidades e à ampliação da acessibilidade capital/interior, principalmente por via rodoviária.

Todavia, refletindo as transformações na economia baiana, emergiram subredes urbanas organizadas em torno das cidades mais importantes da região e que desfrutam de certa autonomia, a exemplo de:

a) Alagoinhas - Tem papel regional substancial, no que tange aos serviços de saúde, hospital e maternidade regionais, clínicas de tratamento de câncer e demais serviços especializados, encontrados somente na capital e em Feira de Santana; serviços financeiros - nesta cidade em 2000, havia oito agências bancárias, três de bancos estatais, dentre os quais um banco de fomento econômico (BNB) existente somente em Salvador, Feira de Santana, Santo Antônio de Jesus e Camaçari, e cinco agências de bancos privados; companhias de seguros; ensino universitário; provedor local de internet; shopping center de porte médio e um comércio numeroso e diversificado; órgãos federais e estaduais da administração descentralizada, especialmente do sistema fiscal - Receita Federal e Secretaria da Fazenda do Estado da Bahia -; Tribunal de Justiça; uma unidade do Exército Brasileiro etc.

Nessa rede urbana, em 1960, depois de Salvador, o município de Alagoinhas era o segundo em população urbana, com quase 43 mil habitantes. Em 2000, sua a população urbana atingiu quase 115 mil habitantes, porém, Camaçari, que 
em 1960, tinha pouco mais de 10 mil habitantes residentes em áreas urbanas, chegou ao ano 2000 concentrando de mais de 150 mil habitantes, ocupando o segundo lugar, superando Alagoinhas que passou para a terceira posição.

A cidade de Alagoinhas tem uma área de influência urbana que se estende a todas as localidades do Litoral Norte da Bahia; atinge a parte Nordeste do estado, até Nova Soure; para o Leste, chega até as cidades de Biritingas e Serrinha; um pouco mais ao Sul, atinge as cidades da zona canavieira e Feira de Santana; e, em direção à capital, alcança Camaçari e Madre de Deus, por meio de linhas diretas de transporte rodoviário de passageiros (Figura 12).

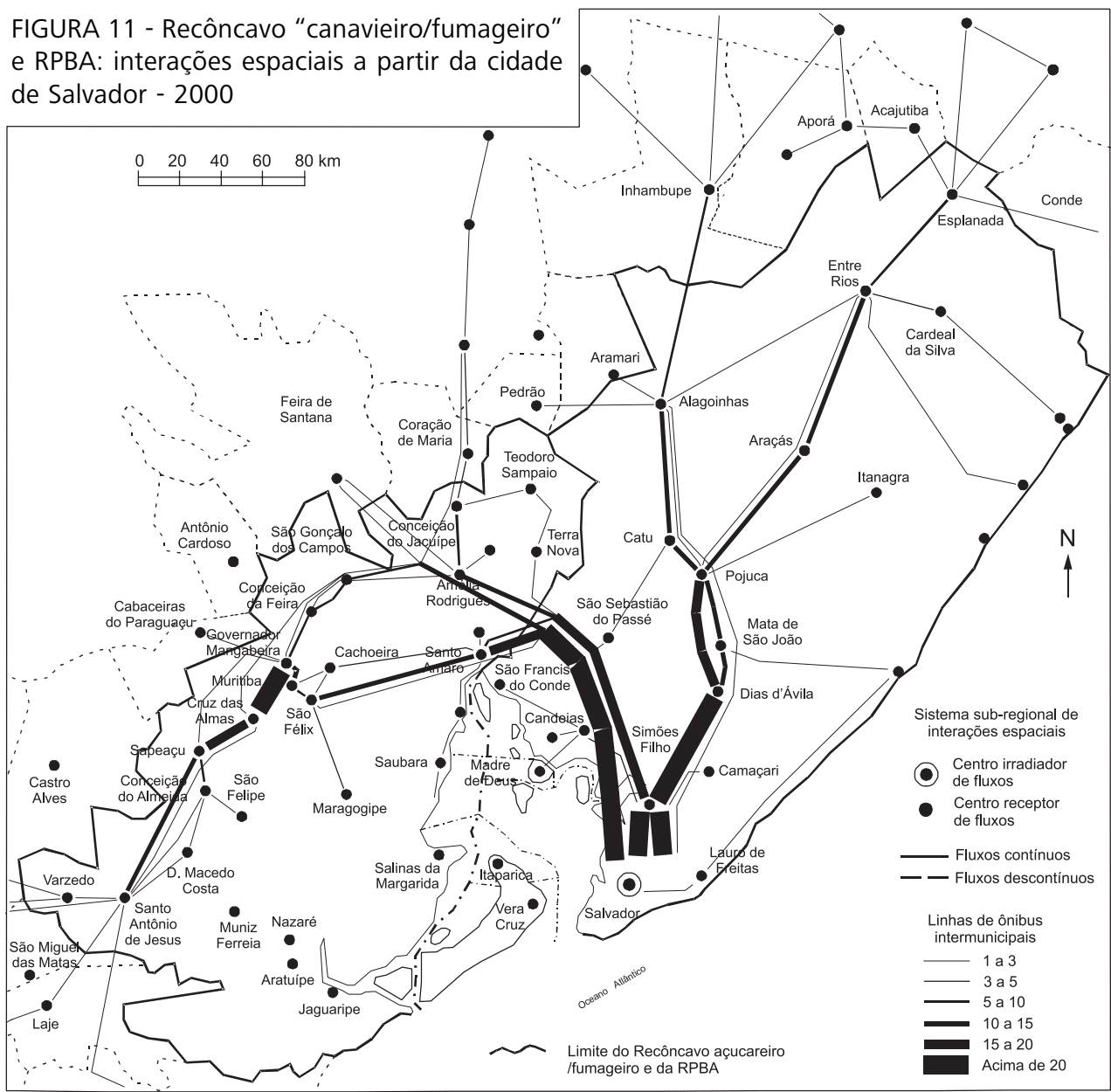

FONTE: Organizada por Brito (2004), com base em: AGERBA, 2000.

Na RPBA, os municípios do entorno de Alagoinhas, até os anos 1960, constituíam uma área predominantemente de criação extensiva de gado e, em menor proporção, de produção de alimentos em pequenas propriedades. Essa estrutura 
agrária e produtiva foi desestabilizada a partir dos anos 1960, com a intensificação da exploração petrolífera, associada à implantação e expansão da Ferbasa, que utiliza madeira em seus processos industriais, e à retomada da pecuária extensiva e semi-intensiva.

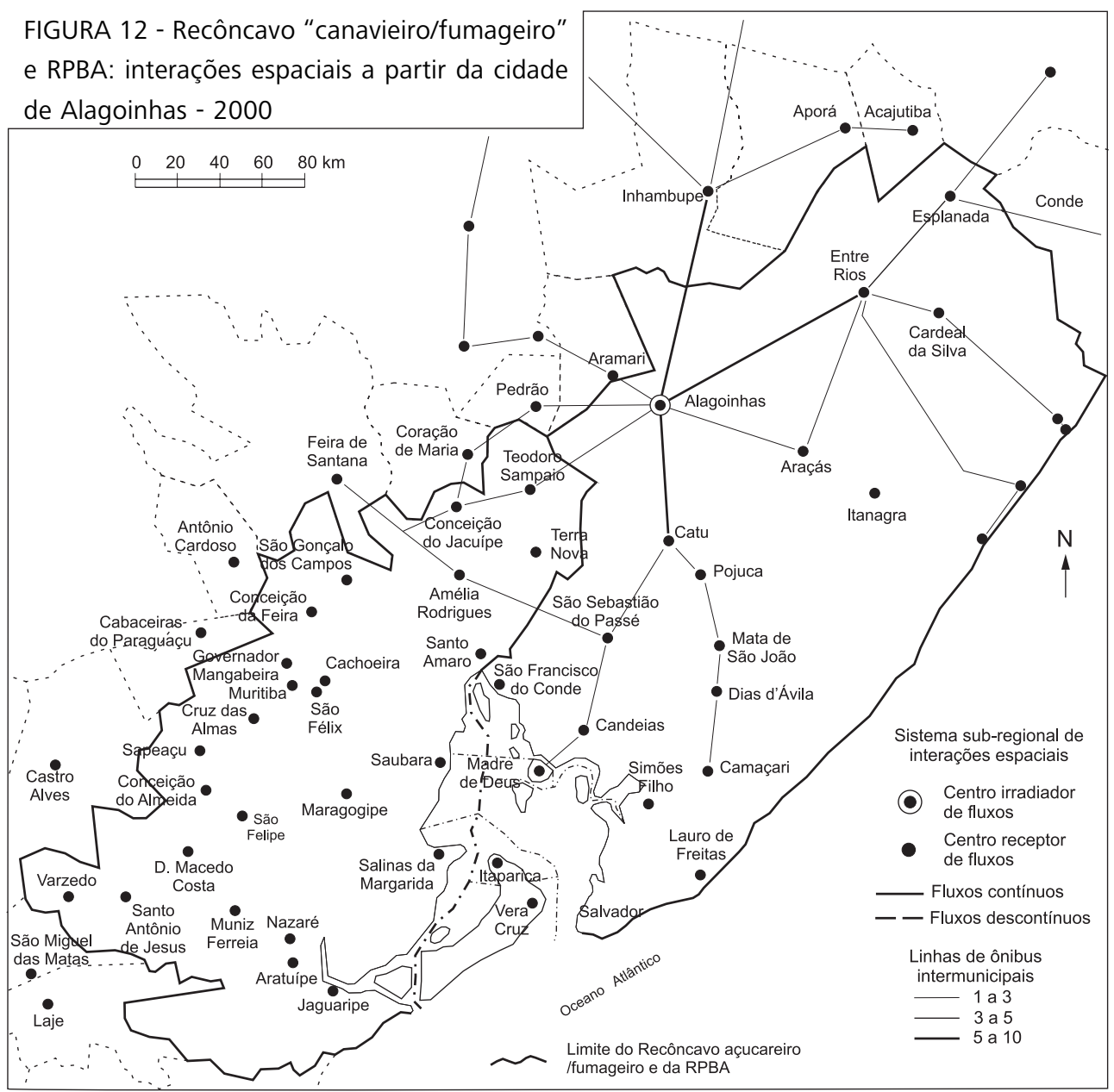

FONTE: Organizada por Brito (2004), com base em Bahia (2001c).

Os investimentos da Petrobras e da Ferbasa não foram suficientes para vencer a inércia econômica instalada na região e nem a quase "desatenção planejada" do Governo do estado, no sentido de prover a região com projetos criadores de sinergia, já que a industrialização na RMS e, em parte, em Feira de Santana, absorvia a maior parte dos recursos, que já eram escassos.

Dessa maneira, o subespaço organizado em torno de Alagoinhas continuou a se desenvolver basicamente por sua própria força de inércia até a primeira metade dos anos 1990, quando o Governo do estado decidiu construir a segunda 
parte da rodovia BA-099, Linha Verde, pelo litoral Norte baiano até a divisa com o estado de Sergipe, e daí até Aracaju.

Essa nova rodovia permitiu abrir o Litoral Norte aos investimentos em empreendimentos turísticos. Em fins dos anos 1990, o município de Alagoinhas foi contemplado com a implantação da fábrica de bebidas da cervejaria Schincariol, o que indica que a sub-região passou a fazer parte dos planos de descentralização dos investimentos do Governo do estado.

b) Feira de Santana - É a segunda cidade no estado da Bahia em número de habitantes - cerca de 500 mil - e constitui-se atualmente num importante pólo universitário e comercial, depois de Salvador. Na década de 1980, o município sediou um centro industrial de destaque, Centro Industrial Subaé (CIS), que subsistiu durante a vigência dos incentivos fiscais da Sudene, e muitas empresas já encerraram suas atividades, mas outras ainda buscam localizar-se neste centro industrial beneficiando-se de incentivos governamentais.

A área de influência de Feira de Santana no interior baiano é bastante extensa, englobando todas as regiões do estado. Essa amplitude ocorre devido à sua posição na hierarquia funcional urbana no estado da Bahia como a segunda maior cidade e também à facilidade do acesso, proporcionada por sua localização na confluência e/ou proximidade de eixos rodoviários nacionais - rodovias BR-116, BR-324, BR-101 e a BR-242 - que torna essa localidade um entreposto interestadual de mercadorias.

Na rede urbana em análise, a cidade de Feira de Santana se faz presente diretamente nos principais nós da rede e em algumas outras cidades, tanto na RPBA, como no Recôncavo "canavieiro/fumageiro", conforme mostra a Figura 13.

c) Santo Antônio de Jesus - Com quase 70 mil habitantes, tem apresentado um destacado papel regional na parte Sul do Recôncavo Baiano, no entorno de Valença e da Baía de Camamu, e na parte da encosta da Chapada Diamantina meridional. Essa região passa por mudanças substanciais na dinâmica econômica e apresenta um relativo dinamismo, pela produção de alimentos e frutas (agricultura comercial), seja pela prática do turismo mais intensa, e ainda pela exploração do petróleo iniciada em fins dos anos 1990 na área em torno do município de Camamu.

A cidade de Santo Antônio de Jesus possui um centro universitário, um shopping center de porte médio, cinemas, companhia de seguros, sete agências bancárias, das quais, três se enquadram na mesma situação de Alagoinhas e quatro agências são de bancos privados, estação geradora de sinal de TV e rádio, provedor de internet local, um comércio varejista grande e diversificado - revenda de automóveis, caminhões, tratores e máquinas agrícolas --, serviços especializados em saúde, reparos em máquinas agrícolas, caminhões e automóveis, dentre outros.

A área de influência urbana direta da cidade de Santo Antônio de Jesus é significativa. A partir da rodovia BR 101, por onde chegam em caminhões as 
mercadorias produzidas nas regiões Sudeste e Sul e do próprio estado da Bahia, projetam-se fluxos rodoviários de passageiros em direção ao litoral, desde a Ilha de Itaparica, atingindo Nazaré, Jaguaripe, Aratuípe, até a Baía de Camamu, área voltada para empreendimentos turísticos, pesca, aqüicultura e produtos agrícolas; para o interior, atinge Cruz das Almas; em direção ao Sertão chegando a Castro Alves, e, mais adiante, alcança Itaberaba, no Vale do Rio Paraguaçu; em direção ao Sudeste, chega a Elísio Medrado, Amargosa e Brejões; mais ao Sul, penetra no Vale do Jequiriçá e chega a Santa Inês e Jaguaquara, todas essas localidades situam-se no limite entre as rodovias BR-116 e a BR-101.

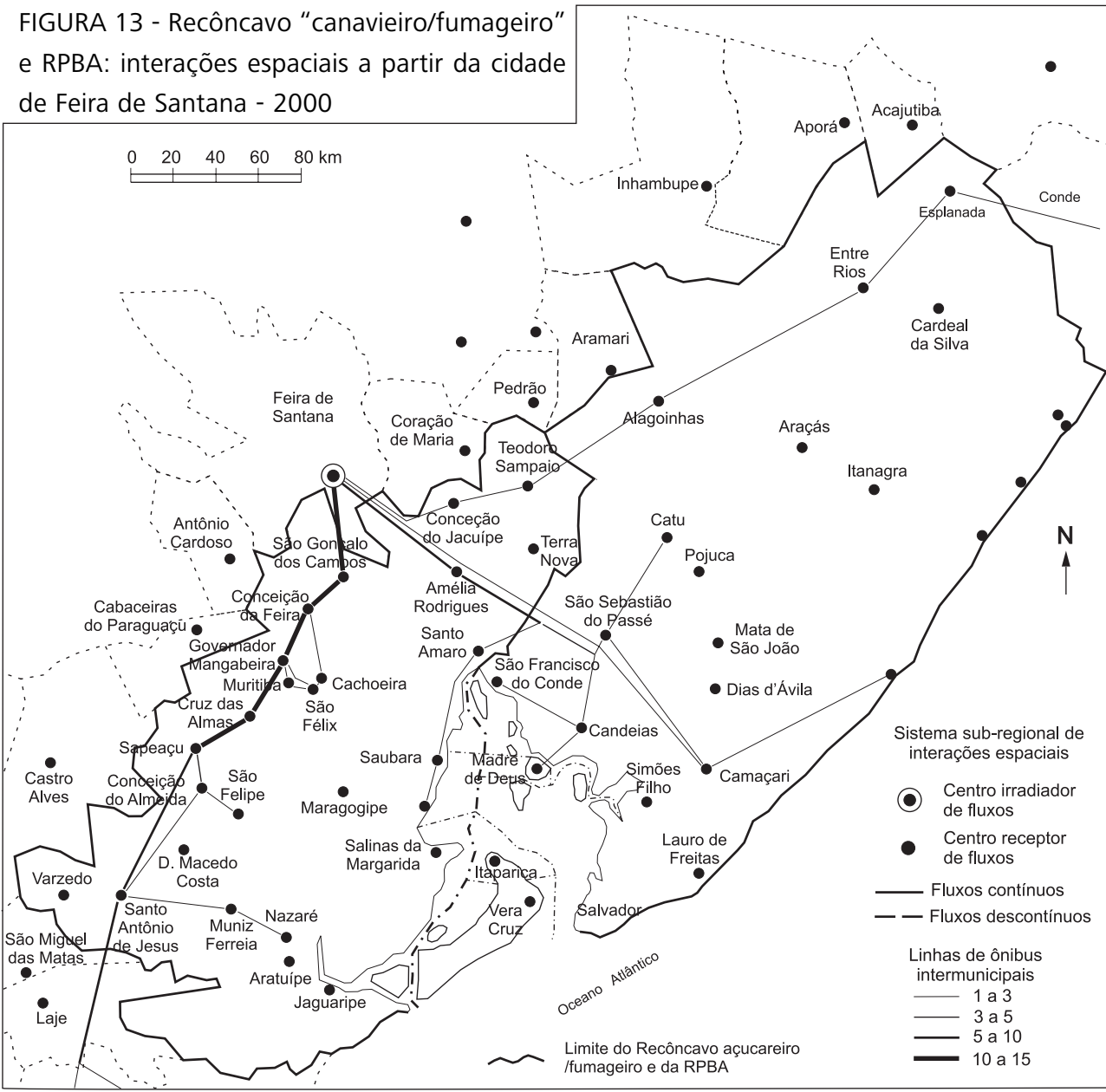

FONTE: Organizada por Brito (2004), com base em Bahia (2001c).

Apesar de os fluxos de transporte rodoviários de passageiros provenientes de Santo Antônio de Jesus cobrirem uma área relativamente extensa, de fato 
é na direção da Ilha de Itaparica que eles ocorrem com maior intensidade (Figura 14).

FIGURA 14 - Recôncavo "canavieiro/fumageiro" e RPBA: interações espaciais a partir da cidade de Santo Antônio de Jesus - 2000

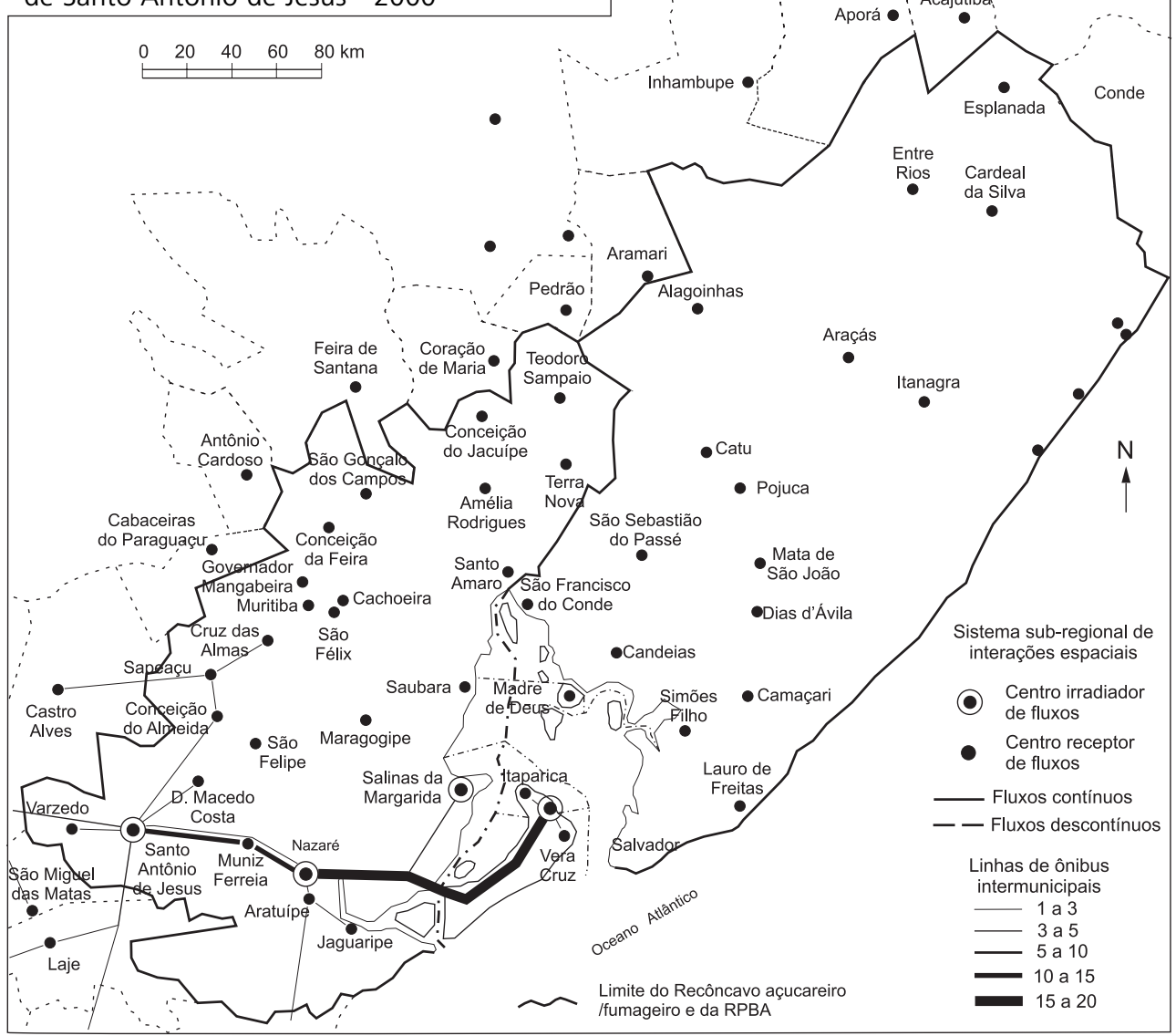

FONTE: Organizada por Brito (2004), com base em Bahia (2001c).

Esse fato é explicado em virtude de o Terminal Rodoviário de Bom Despacho, na Ilha de Itaparica, cujas chegadas e partidas dos ônibus são sincronizadas com as chegadas e partidas dos navios que fazem a travessia Bom Despacho/Salvador, funciona como uma plataforma de embarque e desembarque de Salvador, para as pessoas que se dirigem a localidades próximas ao trajeto entre Santo Antônio de Jesus e Bom Despacho. Com isso, evita-se viajar por um percurso de mais de $100 \mathrm{~km}$ pelas BR-324 e BR-101.

d) Existe ainda um micro-sistema de interações espaciais formado pelos núcleos de Camaçari, Candeias, Lauro de Freitas e Santo Amaro, dentre outros, que se 
complementam e também emitem fluxos para as cidades de Salvador, Alagoinhas e Feira de Santana. Muitos desses fluxos devem-se a deslocamentos de pessoas que se ocupam profissionalmente nas cidades envolvidas (Figura 15).

FIGURA 15 - Recôncavo "canavieiro/fumageiro" e RPBA: interações espaciais a partir da Região Metropolitana de Salvador e outras localidades - 2000

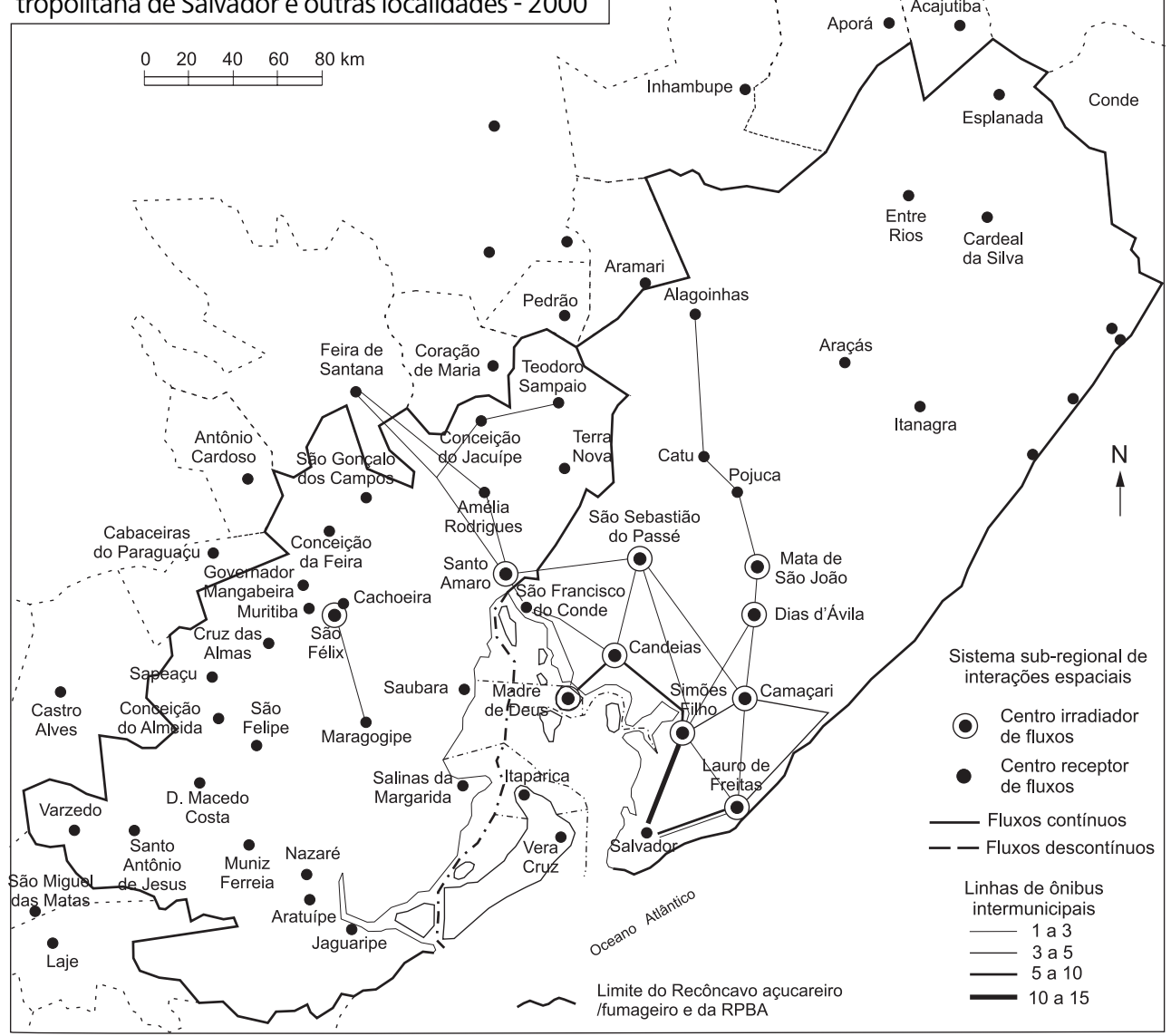

FONTE: Organizada por Cristóvão Brito, com base em Bahia (2004).

Convém explicar que os dados de transporte rodoviário de passageiros utilizados referem-se apenas às rotas oficiais. Porém, entre os povoados, as vilas e cidades próximas verifica-se a coexistência do transporte coletivo extra-oficial, auto-organizado, inclusive com horários e pontos de parada, e em alguns casos concorrente com o sistema oficial de outorga.

Do exposto, infere-se que o isolamento relativo de um núcleo urbano reflete a baixa inserção na divisão espacial da produção e sua posição elementar no subsistema regional que, por sua vez, vincula-se ao seu pequeno tamanho demográfico e à baixa capacidade de geração de riqueza econômica, 
exemplificados pelos seguintes municípios e respectivos núcleos urbanos: Itanagra, Cardeal da Silva, Dom Macedo Costa, Jaguaripe, São Felipe e Muniz Ferreira. O contrário disso tudo se verifica com a existência de núcleos urbanos que possuem maior abertura e forte interação espacial com outros núcleos urbanos localizados interna e externamente à rede urbana sub-regional, como Alagoinhas e Santo Antônio de Jesus (PRED, 1979).

Enfim, em termos gerais, essa é a configuração territorial resultante de múltiplos processos sociais desenvolvidos no Recôncavo "canavieiro/fumageiro" e na RPBA ao longo de meio século. Especificamente na RPBA, a configuração territorial reflete, em grande medida, o processo de gestão desse território pela Petrobras ao longo do tempo.

À medida que as interações espaciais resultantes das relações entre a Petrobras e seus interlocutores iam se processando, se consolidavam estruturas que, em dados momentos, criavam condições para o desenvolvimento de uma nova organização em amplos setores da vida social, econômica, política e urbana, a exemplo da realidade material que se apresenta contemporaneamente. 


\section{Considerações Finais}





\section{Considerações finais}

Espera-se ter oferecido ao longo da exposição as respostas apropriadas e satisfatórias às questões que motivaram a execução da pesquisa. Acreditando-se nisso, à guisa de conclusão, resta sintetizar as principais "idéias-força" contidas neste texto.

Parte-se da compreensão de que os conceitos se prestam a tornar comunicáveis as idéias acerca de dados fenômenos e objetos. Isto é, quando alguém se refere a algum fenômeno ou objeto, os seus interlocutores devem ter em mente as características implícitas e a carga de significados contidos em cada um deles. Entretanto, nem todo conceito está livre de ser portador de múltiplos significados. O conceito de território como substrato do fenômeno de uma territorialidade que também se reveste do status de categoria espacial cara às ciências humanas e em particular à geografia, tal conceito é um desses, que dada a sua polissemia, traz em seu bojo, elementos que, de certo modo, dificultam a compreensão de questões que tocam o mundo das relações entre os seres humanos e sua projeção espacial.

Não é demais repetir que a compreensão mais geral que se tem sobre a idéia de território se encontra eivada de noções apropriadas mais à territorialidade dos animais. Sack (1986) destaca que a diferença entre a territorialidade humana e a animal reside no fato de que, para os homens, o seu significado expressa estratégias de ação com vistas a garantir os interesses e intenções de cada um dos agentes sociais no processo de reprodução de um dado território; para os animais, a territorialidade expressa ações de natureza puramente biológica.

Que a territorialidade humana encerra relações de poder, não resta a menor dúvida, mas isso contribui pouco para a compreensão do conceito de território, se não se tem claro a natureza subjacente desse poder, e em que condições se manifesta.

A pesquisa sobre a reprodução do território da Petrobras no Recôncavo Baiano, entre 1940 e 2000, procurou dar visibilidade aos processos que refletissem as premissas teórico-conceituais acima comentadas. Nesse sentido, elegeu-se, no Recôncavo Baiano, os agentes sociais relevantes que, por meio da interação de suas ações, foram capazes de, num momento, desfazer um território existente, e, em seguida, construir um novo em meio a tantos outros, mas com formato, conteúdo e extensão diferentes do anterior e que se mantém até o presente momento.

O universo político, social, econômico, técnico-produtivo, urbano e infraestrutural que compunha o Recôncavo Baiano por volta dos anos 1940 e 1950, que, em termos gerais, desenvolvia-se segundo condições pouco inovado- 
ras, e mesmo involuía, refletia os limites extremos do baixo nível de geração da riqueza no estado da Bahia à época. Essa situação era realimentada pelos próprios condutores dos processos de formação da riqueza econômica no estado da Bahia, por meio de ações eminentemente especulativas em torno de atividades agromercantis e bancárias, dirigidas a partir da cidade do Salvador.

Dessa maneira, as relações sociais e de produção que se destacavam no território organizado em torno das demandas dos usineiros de açúcar, ao invés de se encaminharem no sentido de incorporar inovações técnicas, progresso econômico e incrementos nas condições de vida da população e, como de resto, dos trabalhadores, principalmente os canavieiros, a cada dia se deterioravam, e as condições de reprodução dos distintos agentes se tornavam precárias (primeiro, os mais vulneráveis - os trabalhadores), até o momento em que as demandas de alguns deles já não eram mais julgadas, e os mecanismos de coação e violência passam a ter lugar quase exclusivo.

É nesse tipo de ambiente, em que as relações baseadas em coações se tornam comuns que se insere a Petrobras e passa a agir de maneira semelhante aos seus interlocutores. Nessas condições, as distensões aumentam e o território organizado em torno das demandas dos usineiros de açúcar, que se mantinha de maneira precária, é dissolvido em fins dos anos 1950.

Em 1959, foi realizada a Conferência do Petróleo, evento que marcou a forma de reação organizada dos interlocutores regionais da Petrobras. O referido conclave contou com a presença não só dos agentes adversários da corporação, mas também com representantes da própria corporação e do CNP. O ambiente em que se desenvolveram os trabalhos, pelo que se indica, foi bastante propenso à equação das questões que envolviam a Petrobras e seus interlocutores regionais. Na ocasião, os agentes adversários da companhia obtiveram dela seu compromisso formal em realizar investimentos industriais na Bahia. Esse foi, sem dúvida, o primeiro sinal do que estava por vir, e serviu para pacificar os ânimos dos interlocutores regionais da companhia.

Após a Conferência do Petróleo, a Petrobras passou a realizar uma série de investimentos industriais que, aos poucos, foi incorporando as demandas dos agentes regionais. A articulação entre os projetos da corporação e os investimentos governamentais com apoio da Sudene, ao longo do tempo, contribuíram sobremaneira para edificar um novo território em que as demandas dos agentes regionais passaram a ser atendidas ao longo do tempo. Durante esse processo, a corporação assumiu a posição de hegemonia nas relações, e, de maneira pactuada, coordenou as condições em que se desenvolveu esse território.

A instalação de indústrias modernas e intensivas em capital, a exemplo do complexo industrial petrolífero, do CIA e do Copec, dentre outros, surgiu como resultado de ações diretas e indiretas da corporação. De outra maneira, o 
surgimento de novos municípios e o desenvolvimento urbano dos antigos, na área petrolífera, teve, na Petrobras, o fator dinamizador, seja pela implantação de uma rede de estradas asfaltadas, quando isso era novidade no Recôncavo Baiano, seja pela circulação de uma substancial massa de dinheiro, decorrente dos gastos da própria corporação e dos salários de seus milhares de funcionários diretos e dos empregados das firmas subcontratadas.

Ao longo dessas páginas esforçou-se em demonstrar que os territórios são construídos, e se mantêm com base em relações sociais entre os agentes mediadas por acordos de parte a parte ou, em outras palavras, pelo poder, mesmo em presença de assimetrias, as quais são próprias do mundo real. A essência do poder considerado nessas bases reforça a idéia arendtiana de que essa categoria somente existe na relação social, e não é privativa de nenhum agente social isolado. Mais que isso, que cada um dos agentes que participa de uma dada relação social o faz de maneira autônoma, segundo suas demandas, expectativas e capacidade de convencer seus interlocutores a orientarem suas ações por suas intenções, sem que seja necessário o recurso de mecanismos de coação ou de violência para fazer concretizar-se tal ou qual intento de um único agente. Os mecanismos de coação e violência podem até aparecer, mas sua aplicação ocorre de maneira instrumental e justificada, com base em princípios de liberdade e justiça em seus sentidos mais extensos, de maneira que, cessadas as condições que motivaram seu aparecimento, esses também desaparecem, tal como esclarece Arendt (1994).

Retomando o pressuposto inicial que motivou este estudo, de que o poder é substantivo para o conceito de território, e em decorrência disso, num dado território onde as relações de poder forem fracas, esse território se encontra em vias de dissolução; e que, ao contrário, no território onde as relações de poder são preponderantes, esse será cada vez mais fortalecido, pode-se concluir dos resultados da pesquisa, que nos processos de dissolução e de construção e reprodução do território no Recôncavo Baiano, as premissas contidas nessa afirmação foram confirmadas.

A idéia de gestão do espaço geográfico, que pode ser ao mesmo tempo também gestão do território, mostra-se desde o início e não apresenta descontinuidades. A gestão se manifesta a partir do momento que a Petrobras passou a instalar os seus sistemas de objetos e a realizar investimentos em sua infraestrutura, numa área selecionada do Recôncavo Baiano, tomando por base a implementação das práticas espaciais - seletividade espacial, reprodução da região produtora e antecipação espacial. Isso quer dizer que a implementação da gestão do espaço geográfico, que é a gestão das diferenças espaciais, não necessariamente requer a anuência de outros agentes; na realidade, a gestão do espaço geográfico depende da decisão e da energia do próprio agente que a executa ou que manda executar. 
A continuidade das ações de gestão do espaço geográfico pela Petrobras numa parte do Recôncavo Baiano (na RPBA), a partir da década de 1960 transformouse na gestão do seu território; dessa vez, as decisões dependeram mais dos acordos entre a companhia e seus interlocutores regionais que da própria potência da companhia.

Os resultados da análise revelaram, também, que a crença na existência do Estado-nacional como a condição para a existência de um território não mais se sustenta. O Estado-nacional pode coexistir entre os demais agentes envolvidos na relação; o seu grau de visibilidade, como a de qualquer outro agente, advém de sua capacidade de convencer os demais a tomar atitudes baseadas nas suas. Isso ficou explícito quando a tecnoburocracia petroleira enquanto um ente do Estado-nacional subverteu a ordem do Governo e decidiu agir no ramo petroquímico e, ainda, construir e operar um pólo petroquímico na Bahia, quando a decisão da cúpula do Governo federal, em plena ditadura militar em sua fase mais dura, foi de a Petrobras não participar da petroquímica e muito menos instalar esse tipo de indústria no Nordeste do Brasil. 
Referências 



\section{Referências}

A BAHIA e o petróleo. A Tarde, Salvador, 27 maio 2001. Caderno 8, p. 1-10.

A FALTA de assucar é um golpe de Magalhães contra o povo. O Momento, Salvador, 26 set. 1947. p. 1.

ABRANCHES, Sérgio Henrique. A empresa pública como agente de políticas do estado: fundamentos teóricos do seu papel, inclusive em face de nossas relações com o exterior. In: ABRANCHES, Sérgio Henrique. Empresa pública no Brasil: uma abordagem multidisciplinar. Brasília: IPEA, 1980. p. 5-32.

ABRANCHES, Sérgio Henrique. Empresa estatal e capitalismo: uma análise comparada. In: MARTINS, Carlos Estevam (Org.). Estado e capitalismo no Brasil. São Paulo: Hucitec; Cebrap, 1977. p. 5-53 (Política e Economia)

AGÊNCIA NACIONAL DE PETRÓLEO. Banco de dados de exploração e produção. Disponível em: <http:// maps.bdep.gov.br/ website/maps/viewer.htm >. Acesso em: 20 maio 2003.

AGÊNCIA NACIONAL DE PETRÓLEO. Guia dos royalties do petróleo e do gás natural. Disponível em: <http://www.anp.gov.br/ doc/conheca/guia_royalties.pdf>. Acesso em: 20 maio 2003.

ALMEIDA, Rômulo. Petroquímica na economia nacional. Petróleo e Petroquímica, Rio de Janeiro, n. 8/9, p. 22-29, maio/jun. 1973.

ANASTASSOPOULOS, Jean-Pierre; BLANC, George; DUSSAUGE, Pierre. Les multinationales publiques. Paris: PUF/IRM, 1985. 256 p. (Col. L'Institut de Recherche et d'Information sur les Multinationales)

ARAÚJO JR., José Tavares de; DICK, Vera Maria. Governo, empresas multinacionais e empresas nacionais: o caso da indústria petroquímica. Pesquisa e Planejamento Econômico, Rio de Janeiro, v. 4, n. 3, p. 629-654, dez. 1974.

ARAÚJO, Tatiana Brito de. Os engenhos centrais e a produção açucareira no Recôncavo Baiano (1875-1909). Salvador: FIEB, 2002. 168 p.

ARENDT, Hannah. A condição humana. Tradução de Roberto Raposo. Rio de Janeiro: Forense Universitária, 1981. 338 p.

ARENDT, Hannah. Sobre a violência. Tradução de André Duarte. Rio de Janeiro: RelumeDumará, 1994. 114 p.

ASEVEDO, Dorothy do Rego. O trabalho feminino na agroindústria fumageira no estado da Bahia: um estudo sociológico. 1975. 73 f. Dissertação (Mestrado em Ciências 
Humanas) - Faculdade de Filosofia e Ciências Humanas, Universidade Federal da Bahia. Salvador.

ASSEMBLÉlA geral da Petrobras aprova: "royalties" de $8 \%$ para estados e municípios produtores de óleo e gás. Revista Petrobras, Rio de Janeiro, n. 187, p. 16-19, set., 1961.

AZEVEDO, Aroldo de. Regiões e paisagens do Brasil. São Paulo: Companhia Editora Nacional, 1952. p. 143-178. (Série Brasileira)

AZEVEDO, José Sérgio Gabrielli de. Industrialização e incentivos fiscais na Bahia: uma tentativa de interpretação histórica. 1975. 153 f. Dissertação (Mestrado em Economia) Faculdade de Ciências Econômicas, Universidade Federal da Bahia. Salvador.

AZEVEDO, Thales de. Ensaios de antropologia social. Salvador: Universidade da Bahia, 1959b. p. 104-119.

AZEVEDO, Thales de. Problemas sociais da exploração do petróleo no Recôncavo. A Tarde, Salvador, 20 jan. 1959a. Suplemento Especial, p. 9-10, 14, 19-20.

AZEVEDO, Thales de; LINS, Edilberto Quintela Vieira. História do Banco da Bahia 1858-1958. Rio de Janeiro: José Olympio, 1969. 271 p. (Documentos Brasileiros, 132)

BACCARIO, Ana Maria. O balanço dos pólos. Química e Derivados, Rio de Janeiro, n. 199, p. 8-23, abr. 1983.

COMPANHIA DE DESENVOLVIMENTO URBANO DO ESTADO DA BAHIA. Vila operária da Usina Cinco Rios. Salvador, 1976. 1 fotografia aérea vertical. Escala 1:8.000. GEO 0-213.

BAHIA. Mapas esquemáticos das rodovias do estado da Bahia. Boletim CPE, Salvador, ano IX, n. 7-8, p. 40-45, jul./ago., 1966.

BAHIA. Plano de desenvolvimento da Bahia 1960-1963: contribuição ao Plano Diretor do Desenvolvimento do Nordeste, da Sudene. Salvador: Imprensa Oficial, 1961. p. 55-59.

BAHIA. Secretaria do Planejamento, Ciência e Tecnologia. Conselho de Desenvolvimento do Recôncavo. Estudos básicos para o projeto agropecuário do Recôncavo: estrutura agrária. Salvador: BAHIA, [1972?]. 93 p. t. III.

BAHIA. Superintendência de Estudos Econômicos e Sociais da Bahia. Anuário Estatístico da Bahia - 2000. Salvador: SEI, 2000.

BAHIA. Superintendência de Estudos Econômicos e Sociais da Bahia. Mapa da divisão político-administrativa do estado da Bahia - 2000. Salvador: SEI, 2001b. Cd-Rom.

BAHIA. Secretaria de Infra-estrutura do Estado da Bahia. Agência Estadual de Regulação de Serviços Públicos de Energia, Transportes e Comunicações da Bahia. Certificado de autorização de tráfego - 2001. Salvador, 2001c. 
BAHIA: um passo à frente na petroquímica. Revista Petrobras, Rio de Janeiro, n. 248, p. 18-21, mar./abr., 1971.

BAHIA. Comissão de Planejamento Econômico do Estado da Bahia. Coordenação de Ação Regional. Resultado das eleições municipais de novembro - 1976. Planejamento. Salvador, CPE, n. 2, v. 7, 123-139, abr./jun., 1979.

BARROSO, Geonísio Carvalho. Aspectos econômicos da produção do petróleo no Brasil. In: INSTITUTO BRASILEIRO DE PETRÓLEO. Economia do Petróleo. Rio de Janeiro, 1959. p. 33-60.

BEAUJEU-GARNIER, Jacqueline. Les migrations vers Salvador (Bresil). Les Cahiers d'OutreMer, Bordeaux, n. 59, p. 291-300, jul./sep., 1962.

BECKER, Bertha. Elementos para construção de um conceito sobre "gestão do território". Cadernos LAGET. n. 1, p. 1-5, 1988.

BIJKER, Wiebe E.; PINCH, Trevor F. Common themes in sociological and historical studies of technology. In: BIJKER, Wiebe E.; PINCH, Trevor F.; HUGHES, Thomas P. (Ed.). The social construction of technological systems: new directions in sociology and of technology. Cambridge/ Massachussetts/London: MIT Press, 1987. p. 7-49.

BORGES, T. Pompeu Accioly. Migrações internas no Brasil. Boletim Geográfico. Rio de Janeiro, n. 144, XVI, p. 358-375, maio/jun., 1958.

BRANDÃO, Maria de Azevedo (Org.). Recôncavo da Bahia: sociedade e economia em transição. Salvador: Academia de Letras da Bahia; UFBA, 1997. 261 p.

BRASIL. Ministério do Trabalho e Emprego. Bases estatísticas: RAIS. Brasília, 2000. CD-ROM. BRASIL. Decreto n. 61.981, de 28 de dezembro de 1967. Estabelece condições para expansão do parque petroquímico no país, e autoriza a criação da sociedade subsidiária da Petróleo Brasileiro S. A. - PETROBRÁS nos têrmos da Lei $n^{\circ} 2.004$, de 3 de outubro de 1953 com êsse mesmo objetivo. LEX: Coletânea de legislação federal e marginália. São Paulo: LEX Editora, 1967. t. IV, p. 1.837-2.440. t. IV.

BRASIL. Decreto n. 53.898, de 29 de abril de 1964. Institui estímulos ao desenvolvimento da Indústria Química. LEX: Coletânea de legislação federal e marginália. São Paulo: LEX Editora, 1964a. t. I. p. 1-492.

BRASIL. Decreto n. 53.975, de 19 de junho de 1964. Cria a Comissão de Desenvolvimento Industrial. LEX: Coletânea de legislação federal e marginália. São Paulo: LEX Editora, 1964b. t. I. p. 1-492.

BRASIL. Decreto n. 56.571, de 9 de julho de 1965. Fixa diretrizes e bases para a expansão da indústria petroquímica. LEX: Coletânea de legislação federal e marginália. São Paulo: LEX Editora, 1965. t. III, p. 873-1448. 
BRASKEM. Site. Disponível em: <http://www.braskem.com.br>. Acesso em: 15 jul. 2003. BRITO, Cristovão de Cássio da Trindade de. A Petrobras e a gestão do território no Recôncavo Baiano. 2004. 299 f. Tese (Programa de Pós-Graduação em Geografia) Centro de Filosofia e Ciências Humanas, Universidade Federal de Santa Catarina. Florianópolis.

BROWETT, John. On the necessity and inevitability of uneven spatial development under capitalism. International Journal of Urban and Regional Research, London, v. 8, n. 2, p. 155-176, 1984.

CAPITAL da Petrobras, seus recursos e liberação de divisas. Revista Petrobras, Rio de Janeiro, n. 184, p. 4-8, 1961.

CÁRIO, Silvio Antônio Ferraz. A relação público-privada na indústria petroquímica brasileira: da estruturação articulada à reestruturação incerta. 1997. 271 f. Tese (Programa de Pós-Graduação em Economia) - Instituto de Economia, Universidade de Campinas, Campinas.

CARVALHO, Getúlio. Petrobras: do monopólio aos contratos de risco. Rio de Janeiro: Forense-Universitária, 1977. 250 p.

CASTORIADIS, Cornelius. A instituição imaginária da sociedade. Tradução de Guy Reynaud. 5. ed. Rio de Janeiro: Paz e Terra, 1982. 418 p. (Col. Rumos da Cultura Moderna; v. 52)

CASTRO, Antônio Barros de. 7 ensaios sobre a economia brasileira. 2. ed. Rio de Janeiro: Forense Universitária, 1975. 248 p. (v. 2)

CHANDLER, Alfred Dupoint. Ensaios para uma teoria histórica da grande empresa. Tradução de Luiz Alberto Monjardim. Rio de Janeiro: FGV, 1998. 342 p.

CLARK, David. Introdução à geografia urbana. Tradução de Lúcia Helena de Oliveira Gerardi; Silvana Maria Pintaudi. São Paulo: DIFEL, 1985. 281 p.

CLARKE, Ian M. The spatial organization of multinational corporations. London: Croom Helm, 1985. p. 1-59

COHN, Amélia. Crise regional e planejamento: o processo de criação da Sudene. 2. ed. São Paulo: Perspectiva, 1978. 165 p. (Col. Debates - Ciências Sociais)

COHN, Gabriel. Petróleo e nacionalismo. São Paulo: DIFEL, 1968. 213 p. (Corpo e Alma do Brasil)

CONTRERAS, Edelmira del Carmen Alveal. Os desbravadores: a Petrobras e a construção do Brasil industrial. Rio de Janeiro: Relume Dumará; Anpocs, 1994. 243 p. 
CORRÊA, Roberto Lobato. Corporação, práticas espaciais e gestão do território. Revista Brasileira de Geografia, Rio de Janeiro, v. 3, n. 54, p. 115-121, jul./set., 1992.

CORRÊA, Roberto Lobato. Territorialidade e corporação: um exemplo. In: SANTOS, Milton; SOUZA, Maria Adélia Aparecida de; SILVEIRA, Maria Laura (Org.). Território, globalização e fragmentação. São Paulo: Hucitec; ANPUR, 1994. p. 251-256.

COSTA PINTO, Luiz de Aguiar. Recôncavo: laboratório de uma experiência humana. Rio de Janeiro: CLACSO, 1958. 149 p.

COUTINHO, Luciano G.; REICHSTUL, Henri Philippe. Investimento estatal 1974-1980: ciclo e crise. In: LESSA, Carlos Francisco; BELLUZZO, Luis Gonzaga de Mello; COUTINHO, Renata. Desenvolvimento capitalista no Brasil: ensaios sobre a crise. São Paulo: Brasiliense, p. 38-58, 1983. (v. 2)

CUNHA, Joaci de Souza. Amargo açúcar: aspectos da história do trabalho e do capital no Recôncavo açucareiro da Bahia: 1945-1964. 1995. 292 f. Dissertação (Mestrado em História) - Faculdade de Filosofia e Ciências Humanas, Universidade Federal da Bahia, Salvador.

DA POIAN, Pedro Paulo. A presença do Estado e da empresa privada na petroquímica brasileira. Petro \& Química, São Paulo, v. 4, n. 32, p. 28-36, abr. 1981.

DAIN, Sulamis. Empresa estatal e política econômica no Brasil. In: MARTINS, Carlos Estevam (Org.). Estado e capitalismo no Brasil. São Paulo: Hucitec; Cebrap, 1977. p. 141-165.

DANNEMANN, Geraldo. Política econômica interna do petróleo. A Tarde, Salvador, 20 jan. 1959. Suplemento Especial, p. 5, 6, 17.

1953-1963: DEZ anos de monopólio estatal do petróleo. Revista Petrobras, Rio de Janeiro, n. 204, p. 9-40, 1963. Caderno especial.

DIAS, Leila Christina. Redes: emergência e organização. In: CASTRO, Iná Elias de; GOMES, Paulo César da Costa; CORRÊA, Roberto Lobato (Org.). Geografia: conceitos e temas. Rio de Janeiro: Bertrand do Brasil, 1995a. p. 141-162.

DIAS, Leila Christina. Réseaux d'information et réseau urbain au Brésil. Paris: Harmattan, 1995b. 172 p.

DIAS, Reinaldo. Gestão pública e meio ambiente: o caso da CESP e das usinas termoelétricas em São Paulo. Gestão e Desenvolvimento. Bragança Paulista, v. 2, n. 1, p. 61-83, jan./jul., 1997.

DIRETORIA agora pode tem mais tempo para dirigir. Revista Petrobras, Rio de Janeiro, n. 219, p. 17-21, mar./abr., 1966. 
DUARTE, Haidine da Silva Barros. Cidade do Rio de Janeiro: descentralização das atividades terciárias - os centros funcionais. Revista Brasileira de Geografia, Rio de Janeiro, v. 1, n. 36, p. 53-98, jan./mar., 1974.

EDITEL. Lista telefônica de Salvador 2000. Curitiba: Editel, 2000. CD-ROM.

EM SANTO Amaro a pequena propriedade cede lugar aos latifúndios. O Momento, Salvador, p. 2, 22 set. 1946.

ESPECIAL: refino de petróleo - 50 anos da RLAM. Gazeta Mercantil - Bahia, Salvador, 15 set., 2000.

EVANS, Peter. A tríplice aliança: as multinacionais, as estatais e o capital nacional no desenvolvimento dependente brasileiro. 2. ed. Tradução de Waltensir Dutra. Rio de Janeiro: Jorge Zahar Editor, 1980. 292 p. (Biblioteca de Ciências Sociais - Economia)

EXPANDE-SE a indústria petroquímica. Revista Petrobras, Rio de Janeiro, n. 203, p. 3337, ago., 1963.

FAORO, Raymundo. Os donos do poder: formação do patronato político brasileiro. 7. ed. Rio de Janeiro: Globo, 1987. p. 399-750. (v. 2)

FARIA, José Eduardo. Poder e legitimidade: uma introdução ao estudo do direito. São Paulo: Perspectiva, 1978. 130 p. (Debates Políticos)

FERNANDES, Gerson. História da descoberta de petróleo no Recôncavo Baiano. Boletim Geográfico, Rio de Janeiro, n. 144, p. 391-393, maio/jun., 1958.

FEDERAÇÃO DAS INDÚSTRIAS DO ESTADO DA BAHIA. Industrialização na Bahia: construindo uma nova estratégia. Salvador, 1995. $97 \mathrm{p}$.

FONSECA, Edgard Fróes da. Aspectos econômicos da distribuição do petróleo no Brasil. In: INSTITUTO BRASILEIRO DE PETRÓLEO. Economia do petróleo. Rio de Janeiro, 1959, p. 79-99.

FOUCAULT, Michel. Microfísica do poder. 14. ed. Tradução de Roberto Machado. Rio de Janeiro: Graal, 1999. 293 p. (Biblioteca de Filosofia e História das Ciências, v. 7)

GNACCARINI, José C. A economia do açúcar: processo de trabalho e processo de acumulação. In: FAUSTO, Boris (Org.). História geral da civilização brasileira: o Brasil republicano (1889-1930). 5. ed. Rio de Janeiro: Bertrand Brasil, 1989. p. 310-344.

GODOI, Emília Pietrafesa de. O sistema do lugar: história, território e memória no sertão. In: NIEMEYER, Ana Maria de; GODOI, Emília Pietrafesa de (Org.). Além dos territórios: para um diálogo entre a etnologia indígena os estudos rurais e estudos urbanos. São Paulo: Mercado de Letras, 1998. p. 97- 131. 
GOMES, Orlando. Desapropriação das terras da zona petrolífera. A Tarde, Salvador, 20 jan. 1959. Suplemento Especial, p. 7, 8, 17, 18, 21, 22.

GOTTMANN, Jean. The significance of territory. Charlottesville: University of Virginia, 1973. 169 p.

GRAMSCl, Antonio. Cadernos do cárcere. Rio de Janeiro: Civilização Brasileira, 2000, 320 p. (v. 3)

GUIMARÃES, Antônio Sérgio Alfredo. A formação e a crise da hegemonia burguesa na Bahia - 1930 a 1964. 1982. 200 f. Dissertação (Mestrado em Ciências Sociais) Faculdade de Filosofia e Ciências Humanas, Universidade Federal da Bahia, Salvador.

GUIMARÃES, Antônio Sérgio Alfredo. Um sonho de classe: trabalhadores e formação de classe na Bahia dos anos oitenta. São Paulo: Hucitec, 1998. 234 p.

HAESBAERT, Rogério. O mito da desterritorialização: do fim dos territórios à multiterritorialidade. 2. ed. Rio de Janeiro: Bertrand Brasil, 2006. 395 p.

HALL, Richard H. Organizações: estrutura e processos. Tradução de Wilma Ribeiro. 3. ed. Rio de Janeiro: Pretice-Hall do Brasil, 1984. 260 p.

HUTCHINSON, Harry William. Tendências de mudança em Vila Recôncavo. In: FERNANDES, Florestan (Org.). Comunidade e sociedade no Brasil: leituras básicas de introdução ao estudo macro-sociológico do Brasil. 2. ed. São Paulo: Editora Nacional, 1975. p. 125137.

HYMER, Stephen. Empresas multinacionais: a internacionalização do capital. Tradução de Aloísio Teixeira. Rio de Janeiro: Graal, 1978. 118 p. (Biblioteca de Economia, 3)

INSTITUTO DO AÇÚCAR E DO ÁLCOOL. Brasil/Açúcar. Rio de Janeiro: IAA, 1972. (Col. Canavieira, 8), $243 \mathrm{p}$.

IBGE. Censo agrícola do estado da Bahia - 1950. Rio de Janeiro: IBGE, 1956. v. 20, t. 2, $194 \mathrm{p}$.

IBGE. Anuário estatístico do Brasil - 1948. Rio de Janeiro, 1949. 563 p.

IBGE. Anuário estatístico do Brasil - 1946. Rio de Janeiro, 1947. 533 p.

IBGE. Censo demográfico - 2000: características da população e dos domicílios - resultados do universo. Rio de Janeiro, 2001. 520 p.

IBGE. Censo demográfico do estado da Bahia - 1950. Rio de Janeiro, 1955a. v. 1, t. 8, $137 \mathrm{p}$.

IBGE. Censo demográfico do estado da Bahia - 1950. Rio de Janeiro, 1955. v. 20, t. 1, $162 \mathrm{p}$. 
IBGE. Censo demográfico do estado da Bahia - 1940. Rio de Janeiro, 1950. t. 1, 481 p. IBGE. Censo demográfico do estado da Bahia - 1960. Rio de Janeiro, [196-]. v. 1, t. 8, $137 \mathrm{p}$.

IBGE. Censo industrial do estado da Bahia - 1980. Rio de Janeiro, 1984. v. 3, t. 2, n. $15,247 \mathrm{p}$.

IBGE. Censo industrial dos estados de Sergipe, Bahia e Minas Gerais - 1960. Rio de Janeiro, 1966. v. 3, t. 4, p. 27-65

IBGE. Censo industrial, comercial e de serviços do estado da Bahia - 1950. Rio de Janeiro, 1956. v. 20, t. 3, 210 p.

IBGE. Censo industrial do estado da Bahia - 1950. Rio de Janeiro, 1955. v. 1, t. 8, 137 p.

IBGE. Enciclopédia dos municípios brasileiros. Rio de Janeiro, 1958. 403 p. (v. 20)

IBGE. Enciclopédia dos municípios brasileiros. Rio de Janeiro, 1958. 429p. (v. 21)

IBGE. Mapa do Brasil. Rio de Janeiro, 1954.

IBGE. Pesquisa industrial - empresa - 2000. Rio de Janeiro, v. 19, n. 1, 2002. 240 p.

IBGE. Região de influência das cidades, 1993. Rio de Janeiro, 2000. 230 p.

IBGE. Sinopse preliminar do censo demográfico do estado da Bahia - 1960. Rio de Janeiro, 1961. $80 \mathrm{p}$.

IBGE. Tabela 1735 - Dados gerais das unidades locais ... Disponível em: < http:// www.sidra. ibge.gov.br/bda/tabela/listabl.asp?z=t\&c=1735>. Acesso em: 20 maio 2003.

INSTITUTO BRASILEIRO DE PETRÓlEO. Produtos petroquímicos básicos. Petróleo e Petroquímica, Rio de Janeiro, n. 1, p. 42-51, out., 1972.

KRAYCHETE SOBRINHO, Gabriel. O capital agro-mercantil e a indústria na Bahia: do primeiro surto industrial à crise de 1930. 1988. 196 f. Dissertação (Mestrado em Economia) - Faculdade de Ciências Econômicas, Universidade Federal da Bahia, Salvador.

LANGE, Frederico Waldemar. Aspectos econômicos da exploração do petróleo no Brasil. In: INSTITUTO BRASILEIRO DE PETRÓLEO. Economia do petróleo. Rio de Janeiro: IBP, 1959. p. 9-31.

LEAL, Victor Nunes. Coronelismo, enxada e voto: o município e o regime representativo no Brasil. 3. ed. São Paulo: Alfa-Omega, 1976. 376 p.

LEFEBVRE, Henry. A re-produção das relações de produção. Tradução de Antônio Ribeiro e M. Amaral. Porto: Publicações Escorpião, 1973. 126 p. (Cadernos O Homem e a sociedade) 
LEFEBVRE, Henry. O direito à cidade. Tradução de Rubens Eduardo Frias. São Paulo: Moraes, 1991. 145 p.

LODI, João Bosco. A entrevista: teoria e prática. 8. ed. São Paulo: Pioneira, 1974. 176 p.

LOJKINE, Jean. O estado capitalista e a questão urbana. Tradução de Estela dos Santos Abreu. 2. ed. São Paulo: Martins Fontes, 1981. 337 p.

LOPES, José Sérgio Leite. O vapor do diabo: o trabalho dos operários do açúcar. 2. ed. Rio de Janeiro: Paz e Terra, 1978. 220 p. (Estudos Brasileiros, 10)

LUTAM os operários da Usina S. Carlos pelos seus direitos. O Momento, Salvador, p. 5, 15 jan., 1949.

MACHADO, Lia Osório. Sociedade urbana, inovação tecnológica e a nova geopolítica. Cadernos LAGET, Rio de Janeiro, n. 5, p. 20-29, 1995.

MANDEL, Ernest. O capitalismo tardio. 2. ed. Tradução de Carlos Eduardo Silveira Matos, Regis de Catro Andrade e Dinah de Abreu Azevedo. São Paulo: Nova Cultural, 1985. 417 p. (Col. Os economistas)

MANZAGOL, Claude. Lógica do espaço industrial. Tradução de Silvia Selingardi Sampaio. São Paulo: DIFEL, 1985. 230 p.

MARIANI, Clemente. Análise do problema econômico baiano. Planejamento, Salvador, v. 4, n. 5, p. 55-121, out./dez., 1977.

MARINHO JR., Ilmar Penna. Petróleo: política e poder (um novo choque do petróleo?). Rio de Janeiro: José Olympio, 1989. 468 p.

MARTINS, José de Souza. O poder do atraso: ensaios de sociologia da história lenta. São Paulo: Hucitec, 1994. 174 p.

MARTINS, Luciano. Estado capitalista e burocracia no Brasil pós-64. Rio de Janeiro: Paz e Terra, 1985. 265 p. (Col. Estudos Brasileiros - Política, 82)

MARX, Karl. O capital: crítica da economia política. Tradução de Reginaldo Santa'Anna. Rio de Janeiro: Bertrand Brasil, 1988.

MARX, Karl. Formações econômicas pré-capitalistas. 5. ed. Tradução de João Maia. Rio de Janeiro: Paz e Terra, 1986. 136 p. (Col. Pensamento Crítico, 3)

MARX, Karl; ENGELS, Friedrich. A ideologia alemã. Tradução dos Editores. São Paulo: Moraes, 1984. 119 p.

MASCARENHAS, José de Freitas. Introdução à petroquímica. Petróleo e Petroquímica, Rio de Janeiro, n. 8/9, p. 3-21, maio/jun. 1973. 
MATARIPE. Revista Petrobras, Rio de Janeiro, n. 203, p. 19-30, ago., 1963.

MATTOS, Wilson Roberto de et al. Uma luz na noite da Bahia: 50 anos de história da Refinaria Landulpho Alves. Salvador: RLAM/Petrobras, 2000. 272 p.

MENDOZA, G. J.; JIMÉNEZ, J. M.; CANTERO, N. O. Ratzel: el territorio, la sociedade y el Estado. In: MENDOZA, G. J.; JIMÉNEZ, J. M.; CANTERO, N. O. El pensamiento geográfico: estudio interpretativo y antologia de textos (de Humboldt a las tendencias radicales). Madrid: Alianza Editorial, 1982. p. 193-203.

MONTESQUIEU, Charles de Secondat. Do espírito das leis. Tradução de Fernando Henrique Cardoso e Leôncio Martins Rodrigues. São Paulo: Abril Cultural, 1973. 569 p. (Col. Os pensadores, v. xxiv)

MORAES, Antônio Carlos Robert (Org.). Ratzel. Tradução de Fátima Murad e Denise Bottman. São Paulo: Ática, 1990. 199 p. (Col. Grandes Cientistas Sociais 59).

MORGAN, Gareth. Imagens da organização. Tradução de Cecília Whitaker Bergamini e Roberto Cada. São Paulo: Atlas, 1996. p. 43-79.

MUNIZ, José. Prossegue firme a greve na Usina S. Carlos. O Momento, Salvador, p. 1, 8, 25 jan. 1949.

MURICY, Arari. Vivem sujeitos a salários de fome os trabalhadores na indústria do Açúcar. O Momento, Salvador, 26 set. 1946, p. 1, 6.

NÃO seja por falta de asfalto. Revista Petrobras, Rio de Janeiro, n. 221, p. 11-19, jul./ ago., 1966.

NASCIMENTO, Anna Amélia Vieira. Memória da Federação das Indústrias do Estado da Bahia. Salvador: FIEB, 1997. 270 p.

O QUE o setor espera desse novo governo. Química e Derivados, Rio de Janeiro, n. 98, p. 19-27, mar., 1974.

OFFNER, Jean-Marc.; PUMAIN, Denise. Réseaux et territories: significations croisées. [Paris]: L'Aube, 1996. p. 175-274.

OLIVEIRA JUNIOR, Franklin. Usina dos sonhos: sindicalismo petroleiro na Bahia (19541964). Salvador: EGBA, 1996. 230 p.

OLIVEIRA, Francisco de. O elo perdido: classe e identidade de classe. São Paulo: Brasiliense, 1987a. $134 \mathrm{p}$.

OLIVEIRA, Francisco de. Elegia para uma re(li)gião: Sudene, Nordeste, planejamento e conflito de classe. 5. ed. Rio de Janeiro: Paz e terra, 1987b. 132 p. (Estudos sobre o Nordeste, 1) 
OLIVEIRA, Waldir Freitas. História de um banco: o Banco Econômico. Salvador: Museu Eugênio Teixeira Leal/Memorial do Banco Econômico, 1993. 375 p.

OS OPERÁRIOS da Usina Aliança exigem aumento. O Momento, Salvador, p. 5, 3 set. 1949.

OS TRABALHADORES de Cachoeira lutam pela conquista de seus direitos. O Momento, Salvador, p. 5-6, 4 fev. 1946.

PERLONGHER, Nestor Osvaldo. O negócio do michê: prostituição viril em São Paulo. 2. ed. São Paulo: Brasiliense, 1987. 261 p.

PERRUCl, Gadiel. A república das usinas: um estudo de história social e econômica do Nordeste - 1889/1930. Rio de Janeiro: Paz e Terra, 1978. 246 p. (Estudos sobre o Nordeste, 2)

PETROBRAS. [Listagem de funcionários por local de residência (Município)]. Salvador: Ascom, 1999.

PETROBRAS. [Listagem de funcionários por local de trabalho]. Salvador: Ascom, 1999. PLANTA DE gasolina natural está em construção. Revista Petrobras, Rio de Janeiro, n. 195, p. 12-14, maio, 1962.

POMIAN, Krzysztof. Tempo/temporalidade. [Lisboa]: Imprensa Nacional-Casa da Moeda, 1993. p. 164-235 (Enciclopédia Einaudi, v. 29).

POULANTZAS, Nicos. Poder político e classes sociais. Tradução de Francisco Silva. 2. ed. São Paulo: Martins Fontes, 1986. 354 p. (Série Novas Direções)

PRADO JUNIOR, Caio. Historia econômica do Brasil. 36. ed. São Paulo: Brasiliense, 1988. 364 p.

PRED, Allan. Sistemas de cidades em economias adiantadas. Tradução de Maria José Cyhlar Monteiro. Rio de Janeiro: Jorge Zahar Editor, 1979. 230 p.

RAFFESTIN, Claude. Por uma geografia do poder. Tradução de Maria Cecília França. São Paulo: Ática, 1993. 269 p. (Série Temas, v. 29, Geografia Política).

RAMIRES, Julio César de Lima. As grandes corporações e a dinâmica sócio-espacial: a ação da Petrobras em Macaé. Revista Brasileira de Geografia, Rio de Janeiro, v. 4, n. 53, p. 115-151, out./dez., 1991.

REED, Mike. Sociologia da gestão. Tradução de Manuela Reis. Oeiras: Celta, 1997. 167 p. REFINARIA LANDULPHO ALVES. Meio século fazendo história. [Salvador]: [2000?]. 45 p. REGO, José Lins do. Usina. 7. ed. Rio de Janeiro: José Olympio, 1973. 259 p. 
RPBA. Revista Petrobras, Rio de Janeiro, n. 272, p. 25-31, abr./maio, 1975.

S. AMARO, feudo do monopólio Magalhães. O Momento, Salvador, 21 set., 1946, p. 2, 6.

SÁ, Carlos espinheira de. A indústria petroquímica no Recôncavo bahiano. A Tarde, Salvador, 20 jan. 1959. Suplemento Especial, p. 15, 16, 18.

SACK, David Robert. Human territoriality: its theory and history. London: Cambridge University, 1986. 255 p.

SAMPAIO, Fernando Talma. Aspectos da regionalização do desenvolvimento industrial: o caso baiano. 1974. 154 f. Dissertação (Mestrado em Economia) - Faculdade de Ciências Econômicas, Universidade Federal da Bahia, Salvador.

SAMPAIO, Nelson de Souza. Eleições bahianas. Revista Brasileira de Estudos Políticos, Belo Horizonte, n. 8, p. 134-161, abr. 1960.

SAMPSON, Anthony. As sete irmãs: as grandes companhias de petróleo e o mundo que elas construíram. Tradução de Luciana Carli. Rio de Janeiro: Arte Nova, 1976. 358 p.

SANTOS, Milton. Espaço e método. São Paulo: Nobel, 1985. 88p.

SANTOS, Milton. A natureza do espaço: técnica e tempo, razão e emoção. 2. ed. São Paulo: Hucitec, 1997. 308 p.

SANTOS, Milton. A rede urbana do Recôncavo. Salvador: Imprensa Oficial da Bahia, 1959a. 38 p.

SANTOS, Milton. O centro da cidade de Salvador. Salvador: Progresso, 1959b. 196 p. SANTOS, Milton. A urbanização brasileira. São Paulo: Hucitec, 1993. 157 p.

SANTOS, Milton. O retorno do território. In: SANTOS, Milton; SOUZA, Maria Adélia Aparecida de; SILVEIRA, Maria Laura (Org.). Território, globalização e fragmentação. São Paulo: Hucitec; ANPUR, 1994. p. 15-20.

SANTOS, Milton. Técnica espaço e tempo: globalização e meio técnico-científico informacional. São Paulo: Hucitec, 1994. 190 p.

SANTOS, Milton; SILVEIRA, Maria Laura. O Brasil: território e sociedade no início do século XXI. Rio de Janeiro: Record, 2001. 471 p.

SANTOS, Valdemiro Lopes dos. A pecuarização do Recôncavo fumageiro: o caso de São Gonçalo dos Campos-Ba. 1990. 251 f. Dissertação (Mestrado em Geografia) - Centro de Filosofia e Ciências Humanas, Universidade Federal de Pernambuco, Recife.

SCHOR, José. Aspectos econômicos da refinação do petróleo no Brasil. In: INSTITUTO BRASILEIRO DE PETRÓLEO. Economia do petróleo. Rio de Janeiro, 1959. p. 61-78. 
SILVA, João Saturnino da. O sistema agroindustrial do Recôncavo Baiano. 1973. 79 f. Dissertação (Mestrado em Ciências Humanas) - Faculdade de Filosofia e Ciências Humanas, Universidade Federal da Bahia, Salvador.

SILVA, Maria Auxiliadora da. Les migrations pour le reconcave du petroleo, SalvadorBA, Brasil. 1972. 101 f. These (UER de Geographie) - Centre du Geographie Appliqué, Université Strasbourg I, Strasbourg.

SILVA, Sylvio Bandeira de Mello e; SILVA, Barbara-Christine Nentwig. Estudos sobre globalização, território e Bahia. Salvador: EDUFBA, 2003. p. 131-153.

SILVA, Sylvio Bandeira de Mello e; SOUZA, Jaimeval Caetano de. Análise da hierarquia urbana do estado da Bahia. Revista Brasileira de Geografia, Rio de Janeiro, v. 53, n. 1, p. 51-79, jan./mar. 1991.

SILVA, Sylvio Carlos Bandeira de Mello e. Urbanização e desenvolvimento regional no estado da Bahia: uma visão sistêmica. 1975. 145 f. Tese (Concurso para Professor Titular) - Instituto de Geociências, Universidade Federal da Bahia, Salvador.

SIMÕES, Ruy. Casa Magalhães. Salvador: Memorial do Banco Econômico, 15 f., 1993. Digitado. Não publicado.

SINGER, Paul. Desenvolvimento econômico e evolução urbana: uma análise da evolução econômica de São Paulo, Blumenau, Pôrto Alegre, Belo Horizonte e Recife. São Paulo: Nacional/EDUSP, 1968. 377 p.

SMITH, Neil. Desenvolvimento desigual: natureza, capital e a produção do espaço. Tradução de Eduardo de Almeida Navarro. São Paulo: Bertrand Brasil, 1988. 250 p.

SOUZA, Guaraci Adeodato Alves de. A população do Recôncavo Baiano. Salvador: Centro de Recursos Humanos da UFBA, 1976. 55 p.

SOUZA, Guaraci Adeodato Alves de. Urbanização e fluxos migratórios para Salvador. In: FARIA, Vilmar. Bahia de todos os pobres. Petrópolis: Vozes/Cebrap, 1980. p. 103-128 (Cadernos Cebrap, 34)

SOUZA, Marcelo José Lopes de. O território: sobre espaço e poder, autonomia e desenvolvimento. In: CASTRO, Iná Elias de; GOMES, Paulo César da Costa; CORRÊA, Roberto Lobato (Org.). Geografia: conceitos e temas. Rio de Janeiro: Bertrand do Brasil, 1995. p. 77-116.

STUMPF, André Gustavo; PEREIRA FILHO, Merval. A segunda guerra: sucessão de Geisel. São Paulo: Brasiliense, 1979. 138 p.

SUAREZ, Marcus Alban. Petroquímica e tecnoburocracia: capítulo do desenvolvimento capitalista no Brasil. São Paulo: Hucitec, 1986. 242 p. (Economia e Planejamento) 
SZMRECSÁNYI, Tamás. O planejamento da agroindústria canavieira do Brasil: 19301975. São Paulo: Hucitec; Unicamp, 1979. (Economia \& Planejamento, Série Teses e Pesquisas), $540 \mathrm{p}$.

TAVARES, Maria da Conceição. Acumulação de capital e industrialização no Brasil. 2. ed. Campinas: Unicamp, 1986. 160 p.

TAYLOR, Michael; THRIFT, Nigel (Ed.). Multinationals and restructuring of the world economy: the geography of multinationals. London: Croom Helm, 1986. p. 1-20

TAYLOR, Michael; THRIFT, Nigel. Business organization, segmentation and location. Regional Studies, v. 17, n. 6, p. 445-460, dec., 1983.

TELEMAR. Lista telefônica de assinantes da Região Norte do estado da Bahia 2000. [s.I.: s.n.], [2000?].

TELEMAR. Lista telefônica de assinantes de Salvador e da Região Metropolitana 2000. [s.l.: s.n.], [2000?].

TORRES, Vasconcelos. Condição de vida do trabalhador na agroindústria do açúcar. Rio de Janeiro: IAA, 1945. 277 p.

TOURINHO, Borba. Contrôle do subsolo pelo estado: uma constante da legislação brasileira. Revista Petrobras, Rio de Janeiro, n. 183, p. 12-16, 1961.

TZU, Sun. A arte da guerra. Tradução de Pietro Nasseti. São Paulo: Martin-Claret, 2001. $143 \mathrm{p}$.

UNIÃO: uma corrida contra a procura. Química e Derivados, Rio de Janeiro, n. 100, p. 22-33, maio, 1974.

VIANA FILHO, Luiz. Petroquímica e industrialização da Bahia - 1967-1971. Brasília: Senado Federal/Centro Gráfico, 1984. 154 p.

VICTOR, Mário. A batalha do petróleo brasileiro. Rio de Janeiro: Civilização Brasileira, 1970. 405 p.

VIDA e obra de Raymundo Pereira de Magalhães. A Tarde, Salvador, 24 jul. 1954, p. 9.

VOLTAIRE, François Marie Arouet de. Cartas inglesas; Tratado de metafísica; Dicionário filosófico; O filósofo ignorante. 2. ed. Tradução de Marilena de Souza Chauí et al. São Paulo: Abril Cultural, 1978. 328 p. (Col. Os Pensadores)

WEBER, Max. Economia e sociedade: fundamentos da sociologia compreensiva. Tradução de Regis Barbosa e Karen Elabe Barbosa. Brasilia: EDUNB, 1991. p. 3-35 (v. 1)

WIRTH, John D. A política do desenvolvimento na era Vargas. Tradução de Jefferson Barata Rio de Janeiro: FGV, 1973. 216 p. 
ZORZO, Francisco Antônio. Ferrovia e rede urbana na Bahia: doze cidades conectadas pela ferrovia no Sul do Recôncavo e Sudeste Baiano (1870-1930). Feira de Santana: UEFS, 2001. 264 p. 



\section{Anexo A}

\section{CARTA DO PETRÓLEO}

(Retirado de: A TARDE, 24/01/1959, p. 1)

Roteiro para ação conjugada do futuro governo do estado e dos representantes bahianos no Congresso Nacional, no sentido de defenderem os interesses da nossa terra, nesse importante domínio.

A Conferência do Petróleo reconhece:

1) o direito do estado da Bahia e de seus municípios a haverem da União, gratuitamente, ações ordinárias da PETROBRAS, tantos quantos bastem a fazer, respectivamente, $8 \%$ e $2 \%$ do valor de suas jazidas - assim o atribuindo para a constituição inicial do capital da empresa, como o que, determinando um correspondente aumento de capital, for estabelecido pela incorporração de novas jazidas, ou pela reavaliação das existentes, reavaliação esta que deverá ser feita sempre que aconselhada por sensivel alteração das mesmas jazidas;

2) que, em todo aumento de capital, feito na vigência do Decreto $n^{\circ} 40.485$, a avaliação das jazidas deverá ser procedida de acordo com ele, possibilitando, assim, ao Estado interferir na escolha dos peritos (Lei $n^{\circ}$ 2.627, art. 5 e seguintes).

A Conferência do Petróleo recomenda:

3) à bancada federal bahiana estudar o Projeto $n$ 4.247/58 de autoria do deputado Vasco Neto Filho, a fim de votar uma medida legislativa, que ampare, eqüitativamente, o direito dos superficiários;

4) que todo e qualquer dano causado pela PETROBRAS aos proprietários superficiários seja indenizado, de preferência, de modo amigável, no mais curto prazo possível, para o que deverá ser estudada a organização de um processo administrativo adequado, ressalvado, evidentemente, o direito dos aludidos proprietários recorrerem ao poder judiciário, se assim julgarem por bem. Quanto aos prejuízos que a PETROBRAS possa causar aos superficiários, pela ocupação temporária de suas propriedades, deverão ser previamente compensados por um justo preço, arbitrado amigavelmente, à vista dos planos de trabalho. Aos aludi- 
dos proprietários fica sempre ressalvado o direito a uma indenização maior, se os prejuízos afinal excederem aquela estimativa no mais breve prazo possível e de modo amigável, ficando, todavia, livre, aos mesmos proprietários, o recurso ao Judiciário, se lhes convier;

5) a inclusão de, pelo menos, um representante da Bahia no Conselho Nacional do Petróleo, no Conselho de Administração, na Diretoria Executiva e no Conselho Fiscal da PETROBRAS;

6) a modificação do tabelamento do CNP. A fim de que os derivados do petróleo sejam mais baratos na Bahia, como sucede em toda região produtora, em lugar da política de preços que fixa, para a Bahia, custos mais elevados da gasolina e do óleo diesel do que os vigentes em algumas praças do País;

7) a apresentação de um projeto de lei fixando novo critério de rateio do imposto único sobre combustíveis e lubrificantes, no qual se atribua ao fator de produção mais justa na distribuição do impôsto;

8) que o cálculo da receita, resultante da matéria-prima nacional, para efeito do cômputo do imposto único sobre combustíveis líquidos, leve em conta os derivados de matéria-prima importada, em quantidade equivalente à matériaprima nacional, que o CNP e a PETROBRAS preferem exportar;

9) a fixação de novo e mais justo "royalty" para Estados e Municípios produtores, encarecendo-se que o CNP adote normas destinadas a apressar o pagamento do "royalty" devido;

10) o pagamento do "royalty" sobre a produção de poços submarinos;

11) sejam destacadas as atuais unidades da PETROBRAS na Bahia, para constituírem sociedades subsidiárias, nas quais o Estado e os Municípios participem, efetivamente, no capital com o mínimo de $20 \%$, segundo a legislação em vigor, devendo, por modificação legal, esse limite ser ampliado, sem prejuízo da posição majoritária da PETROBRAS; e que a constituição de outras sociedades subsidiárias obedeça ao mesmo princípio, para o desenvolvimento das atividades derivadas, que se revelem convenientes para o desenvolvimento regional. A realização da quota do Estado e dos Municípios nas subsidiárias poderá ser feita mediante conversão de suas ações na PETROBRAS ou ainda, a longo prazo, mediante a conversão dos "royalties" devidos ao Estado;

12) que se criem condições adequadas a introduzir empresas privadas a instalarem na Bahia atividades industriais derivadas importantes para o desenvolvimento regional, inclusive e imediatamente a Usina de mistura de lubrificantes, sempre que não convenha à PETROBRAS que ela o faça, diretamente, ou por suas subsidiárias;

13) considerando a importância da PETROBRAS, como um fator permanente e contínuo ao desenvolvimento econômico da Bahia, que sejam mobilizados todos os esforços e negociações junto à União e àquela empresa, no sentido de, simul- 
taneamente, com a programa de extração e refino de óleo, instalar a PETROBRAS subsidiárias para a exploração da indústria petroquímica e criar condições adequadas à atração de capitais, que sob sua orientação, se dediquem a tais investimentos;

14) a atualização periódica, pelo Conselho Nacional do Petróleo, com a presença de representantes da Bahia, do valor do petróleo e do gás extraído na região, de acordo com os preços vigentes no mercado internacional, para efeito do pagamento do "royalty";

15) sejam considerados os portos de llhéus e de caravelas entre os portos base, para efeito de fixação dos preços CIF uniformes, nas bases de abastecimento no litoral brasileiro e em mais outros portos que o desenvolvimento das zonas tributárias o justifique;

16) que a PETROBRAS, em convênio com o Estado da Bahia, o Município do salvador e os Municípios da região de produção, participe da elaboração e execução de um programa destinado à ampliação de obras, serviços e outras "economias externas" no Estado de forma a elevar a produtividade na área que se pretende industrializar;

17) que nos convênios ou acordos, para aplicação em comum, por parte do estado, dos Municípios e da a Bahia PETROBRAS, de "royalties" ou outros proventos, sejam efetivamente atendidos os interesses do desenvolvimento econômico do Estado e de seus Municípios;

18) que, atendendo ao que, justamente aspiram os Municípios, seja reconhecida a estes, independentemente de ação judiciária a cobrança do imposto de indústria e profissões, sobre as atividades de refino e produção de derivados do petróleo;

19) que seja efetivamente obedecida a disposição do emprego do gás como matéria-prima para a indústria petroquímica, em vez do seu uso como combustível;

20) a preservação e liberação do gás natural, a ser aplicado como matériaprima em indústrias petroquímicas, evitando-se sempre que possível, o seu uso nas operações de recuperação de óleo;

21) o prosseguimento da política de ampliação da refinaria de Mataripe, de modo a esta vir a suprir de combustíveis líquidos a Bahia, o Nordeste e o Norte e, também, da prioridade no processamento e suprimento de óleos lubrificante para todo o País;

22) a elaboração de um plano de recuperação econômica e de recolonização por meio de pequenas propriedades das áreas ocupadas pela PETROBRAS;

23) que a PETROBRAS continue incrementando, seja diretamente, seja por meio de Convênios, cursos de formação de mão-de-obra qualificada. 


\section{Colofão}

\begin{tabular}{|c|c|}
\hline Formato & $17 \times 24 \mathrm{~cm}$ \\
\hline Tipologia & Frutiger - Next LT, 45 light, regular \\
\hline Papel & $\begin{array}{l}\text { Pólem } 75 \mathrm{~g} / \mathrm{m}^{2} \text { (miolo) } \\
\text { Cartão Supremo } 250 \mathrm{~g} / \mathrm{m}^{2} \text { (capa) }\end{array}$ \\
\hline Impressão & Setor de Reprografia da EDUFBA \\
\hline Capa e Acabamento & ESB - Serviços Gráficos \\
\hline Tiragem & 300 exemplares \\
\hline
\end{tabular}

